\author{
K.Zh. Nazarova*, K.I. Usmanov
}

Khoja Akhmet Yassawi International Kazakh-Turkish University, Turkistan, Kazakhstan

(E-mail: gjnazarova@mail.ru,y_kairat@mail.ru)

\title{
Unique solvability of boundary value problem for functional differential equations with involution
}

\begin{abstract}
In this paper, we consider a boundary value problem for systems of Fredholm type integral-differential equations with involutive transformation, containing derivative of the required function on the right-hand side under the integral sign. Applying properties of an involutive transformation, original boundary value problem is reduced to a boundary value problem for systems of integral-differential equations, containing derivative of the required function on the right side under the integral sign. Assuming existence of resolvent of the integral equation with respect to the kernel $\tilde{K}_{2}(t, s)$ (this is the kernel of the integral equation that contains the derivative of the desired function) and using properties of the resolvent, integral-differential equation with a derivative on the right-hand side is reduced to a Fredholm type integral-differential equation, in which there is no derivative of the desired function on the right side of the equation. Further, the obtained boundary value problem is solved by the parametrization method created by Professor D. Dzhumabaev. Based on this method, the problem is reduced to solving a special Cauchy problem with respect to the introduced new functions and to solving systems of linear algebraic equations with respect to the introduced parameters. An algorithm to find a solution is proposed. As is known, in contrast to the Cauchy problem for ordinary differential equations, the special Cauchy problem for systems of integral-differential equations is not always solvable. Necessary conditions for unique solvability of the special Cauchy problem were established. By using results obtained by Professor D. Dzhumabaev, necessary and sufficient conditions for the unique solvability of the original problem were established.
\end{abstract}

Keywords: system of integral-differential equations, boundary value conditions, parametrization method, integral equation, resolvent, involution, unique solvability, Special Cauchy Problem.

\section{Introduction}

Boundary value problems for integral-differential equations have been studied by many authors [1-7], however, with the development of computer technology, the question of creating constructive methods for solving the problem arises. In connection with this, Professor D. Dzhumabaev proposed a method for parameterizing the solution of a linear two-point boundary value problem for systems of differential equations [8]. This method was applied to study various boundary value problems [9-14].

On the segment $[0, T]$ we consider the following boundary value problem:

$$
\begin{gathered}
\frac{d x(t)}{d t}+\operatorname{diag}\left(a_{1}, a_{2}, \ldots, a_{n}\right) \frac{d x(\alpha(t))}{d t}=\int_{0}^{T} K_{1}(t, s) x(s) d s+\int_{0}^{T} K_{2}(t, s) \dot{x}(s) d s+f(t), \quad t \in[0, T], \\
B x(0)+C(T)=d, d \in R^{n},
\end{gathered}
$$

where the matrices $K_{1}(t, s), K_{2}(t, s)$ are continuous on $[0, T] \times[0, T]$, respectively, $n$-dimensional vector-function $f(t)$ is continuous on $[0, T] . \alpha(t)$ is a reorientation homeomorphism $\alpha:[0, T] \rightarrow[0, T]$ such that $\alpha^{2}(t)=$ $=\alpha(\alpha(t))=t$. It is known that the homeomorphism $\alpha(t)$ is called the involutive transformation. On the segment $[0, T]$ as such a transformation, we can consider the transformation $\alpha(t)=T-t$. Properties of the involutive transformation were studied by G.S. Litvinchuk [14], N.K. Karapetyants and S.G. Samko [15] and others.

\footnotetext{
${ }^{*}$ Corresponding author.

E-mail: gjnazarova@mail.ru
} 
We consider a value of equation (1) at the point $t=\alpha(t)$

$$
\frac{d x(\alpha(t))}{d t}+\operatorname{diag}\left(a_{1}, a_{2}, \ldots, a_{n}\right) \frac{d x(t)}{d t}=\int_{0}^{T} K_{1}(\alpha(t), s) x(s) d s+\int_{0}^{T} K_{2}(\alpha(t), s) \dot{x}(s) d s+f(\alpha(t)) .
$$

From the system

$$
\left\{\begin{array}{l}
\frac{d x(t)}{d t}+\operatorname{diag}\left(a_{1}, a_{2}, \ldots, a_{n}\right) \frac{d x(\alpha(t))}{d t}=\int_{0}^{T} K_{1}(t, s) x(s) d s+\int_{0}^{T} K_{2}(t, s) \dot{x}(s) d s+f(t), \\
\frac{d x(\alpha(t))}{d t}+\operatorname{diag}\left(a_{1}, a_{2}, \ldots, a_{n}\right) \frac{d x(t)}{d t}=\int_{0}^{T} K_{1}(\alpha(t), s) x(s) d s+\int_{0}^{T} K_{2}(\alpha(t), s) \dot{x}(s) d s+f(\alpha(t))
\end{array}\right.
$$

we define

$$
\begin{aligned}
& \operatorname{diag}\left(1-a_{1}^{2}, 1-a_{2}^{2}, \ldots, 1-a_{n}^{2}\right) \frac{d x(t)}{d t}=\int_{0}^{T}\left[K_{1}(t, s)-\operatorname{diag}\left(a_{1}, a_{2}, \ldots, a_{n}\right) K_{1}(\alpha(t), s)\right] x(s) d s+ \\
& +\int_{0}^{T}\left[K_{2}(t, s)-\operatorname{diag}\left(a_{1}, a_{2}, \ldots, a_{n}\right) K_{2}(\alpha(t), s)\right] \dot{x}(s) d s+\left[f(t)-\operatorname{diag}\left(a_{1}, a_{2}, \ldots, a_{n}\right) f(\alpha(t))\right] .
\end{aligned}
$$

Suppose that the matrix $\operatorname{diag}\left(1-a_{1}^{2}, 1-a_{2}^{2}, \ldots, 1-a_{n}^{2}\right)$ is not degenerate, then it is invertible, and boundary value problem (1)-(2) can be written in the form

$$
\begin{gathered}
\frac{d x}{d t}=\int_{0}^{T} \tilde{K}_{1}(t, s) x(s) d s+\int_{0}^{T} \tilde{K}_{2}(t, s) \dot{x}(s) d s+\tilde{f}(t), \quad t \in[0, T], \\
B x(0)+C x(T)=d, \quad d \in R^{n},
\end{gathered}
$$

where

$$
\begin{gathered}
\tilde{K}_{1}(t, s)=\operatorname{diag}\left(1 /\left(1-a_{1}^{2}\right), 1 /\left(1-a_{2}^{2}\right), \ldots, 1 /\left(1-a_{n}^{2}\right)\right)\left[K_{1}(t, s)-\operatorname{diag}\left(a_{1}, a_{2}, \ldots, a_{n}\right) K_{1}(\alpha(t), s)\right], \\
\tilde{K}_{2}(t, s)=\operatorname{diag}\left(1 /\left(1-a_{1}^{2}\right), 1 /\left(1-a_{2}^{2}\right), \ldots, 1 /\left(1-a_{n}^{2}\right)\right)\left[K_{2}(t, s)-\operatorname{diag}\left(a_{1}, a_{2}, \ldots, a_{n}\right) K_{2}(\alpha(t), s)\right], \\
\tilde{f}(t)=\operatorname{diag}\left(1 /\left(1-a_{1}^{2}\right), 1 /\left(1-a_{2}^{2}\right), \ldots, 1 /\left(1-a_{n}^{2}\right)\right)\left[f(t)-\operatorname{diag}\left(a_{1}, a_{2}, \ldots, a_{n}\right) f(\alpha(t))\right] .
\end{gathered}
$$

Condition $A$. Let the following Fredholm integral equation of the second kind

$$
z(t)=\int_{0}^{T} \tilde{K}_{2}(t, s) z(s) d s+\Phi(t)
$$

has a unique solution for any function $\Phi(t) \in C\left([0, T], R^{n}\right)$.

If Condition A holds, then there exists $\Gamma_{2}(t, s ; 1)$ - resolvent of the Fredholm integral equation of the second kind with the kernel $\tilde{K}_{1}(t, s)$ and a solution of the integral equation can be written as

$$
z^{*}(t)=\Phi(t)+\int_{0}^{T} \Gamma_{2}(t, s ; 1) \Phi(s) d s
$$

By using Condition A, problem (3) - (4) can be rewritten as

$$
\begin{gathered}
\frac{d x}{d t}=\int_{0}^{T} \tilde{K}_{1}(t, s) x(s) d s+\tilde{f}(t)+\int_{0}^{T} \Gamma_{2}(t, \tau ; 1)\left[\int_{0}^{T} \tilde{K}_{1}(\tau, s) x(s) d s+\tilde{f}(\tau)\right] d \tau, \quad t \in[0, T], \\
B x(0)+C x(T)=d, d \in R^{n} .
\end{gathered}
$$


Changing the order of integration in the integral term we obtain

$$
\int_{0}^{T} \Gamma_{2}(t, s ; 1) \int_{0}^{T} \tilde{K}_{1}(s, \tau) x(\tau) d \tau d s=\int_{0}^{T}\left(\int_{0}^{T} \Gamma_{2}(t, \tau ; 1) \tilde{K}_{1}(\tau, s) d \tau\right) x(s) d s=\int_{0}^{T} K^{*}{ }_{1}(t, s) x(s) d s .
$$

We denote

$$
\begin{gathered}
\hat{K}_{1}(t, s)=K^{*}{ }_{1}(t, s)+\tilde{K}_{1}(t, s), \\
\hat{f}(t)=\tilde{f}(t)+\int_{0}^{T} \Gamma_{2}(t, \tau ; 1) \tilde{f}(\tau) d \tau .
\end{gathered}
$$

Then we rewrite problem (5) - (6) in the form:

$$
\begin{gathered}
\left.\frac{d x}{d t}=\int_{0}^{T} \hat{K}_{1} t, s\right) x(s) d s+\hat{f}(t), \quad t \in[0, T], \\
B x(0)+C x(T)=d, \quad d \in R^{n} .
\end{gathered}
$$

We take the step $h>0$, that fits $N$ times on the segment $[0, T]$ and along it we consider the partition $[0, T)=\bigcup_{r=1}^{N}[(r-1) h, r h)$

We denote restriction of the function $x(t)$ on the r-th interval $[(r-1) h, r h)$ by $x_{r}(t)$, i.e., $x_{r}(t)$ is a system of vector functions defined and coinciding with $x(t)$ on $[(r-1) h, r h)$. Then, the original two-point boundary value problem for systems of integral-differential equations is reduced to the equivalent multipoint boundary value problem

$$
\begin{gathered}
\frac{d x_{r}}{d t}=\sum_{j=1}^{N} \int_{(j-1) h}^{j h} \hat{K}_{1}(t, s) x_{j}(s) d s+\hat{f}(t), t \in[(r-1) h, r h), \\
B x_{1}(0)+C \lim _{t \rightarrow T-0} x_{N}(t)=d, \\
\lim _{t \rightarrow s h-0} x_{s}(t)=x_{s+1}(s h), s=\overline{1, N-1} .
\end{gathered}
$$

Here (11) are gluing conditions at the interior points of the partition $t=j h, j=\overline{1, N-1}$.

If the function $x(t)$ is a solution to problem (7)-(8), then the system of its restrictions $x[t]=\left(x_{1}(t), x_{2}(t), \ldots\right.$, $\left.x_{N}(t)\right)^{\prime}$ will be a solution of multipoint boundary value problem (9)-(11). And in inverse, if the system of vector functions $\tilde{x}[t]=\left(\tilde{x}_{1}(t), \tilde{x}_{2}(t), \ldots, \tilde{x}_{N}(t)\right)^{\prime}$ is a solution to problem (9)-(11), then the function $\tilde{x}(t)$, defined by the equalities $\tilde{x}(t)=\tilde{x}_{r}(t), t \in[(r-1) h, r h), r=\overline{1, N}, \tilde{x}(T)=\lim _{t \rightarrow T-0} \tilde{x}_{N}(t)$ will be a solution of original boundary value problem (7)-(8). By $\lambda_{r}$ we denote a value of the function $x_{r}(t)$ at the point $t=(r-1) h$ and on each interval $[(r-1) h, r h)$ we change $x_{r}(t)=u_{r}(t)+\lambda_{r}, r=\overline{1, N}$. Then problem (9)-(11) is reduced to the equivalent multipoint boundary value problem with parameters

$$
\begin{gathered}
\frac{d u_{r}}{d t}=\sum_{j=1}^{N} \int_{(j-1) h}^{j h} \hat{K}_{1}(t, s)\left[u_{j}(s)+\lambda_{j}\right] d s+\hat{f}(t), \\
u_{r}[(r-1) h]=0, t \in[(r-1) h, r h), r=\overline{1, N}, \\
B \lambda_{1}+C \lambda_{N}+C \lim _{t \rightarrow T-0} u_{N}(t)=d, \\
\lambda_{s}+\lim _{t \rightarrow s h-0} u_{s}(t)=\lambda_{s+1}, s=\overline{1, N-1 .}
\end{gathered}
$$

Problems (9)-(11) and (12)-(15) are equivalent in the sense that if the system of functions $x[t]=\left(x_{1}(t)\right.$, $\left.x_{2}(t), \ldots, x_{N}(t)\right)^{\prime}$ is a solution of problem (9)-(11), then pair $(\lambda, u[t])$ will be a solution of the problem (12)-(15), where $\left.\lambda=\left(x_{1}(0), x_{2}(h), \ldots, x_{N}(N-1) h\right)\right)^{\prime}, u[t]=\left(x_{1}(t)-x_{1}(0), x_{2}(t)-x_{2}(h), \ldots, x_{N}(t)-x_{N}((N-\right.$ $-1) h)$. And in inverse, if pair $(\tilde{\lambda}, \tilde{u}[t])$ is a solution of the problem $(12)-(15)$, where $\tilde{\lambda}=\left(\tilde{\lambda}_{1}, \tilde{\lambda}_{2}, \ldots, \tilde{\lambda}_{N}\right)^{\prime}$, 
$\tilde{u}[t]=\left(\tilde{u}_{1}(t), \tilde{u}_{2}(t), \ldots, \tilde{u}_{N}(t)\right)^{\prime}$, then the system of functions $\tilde{x}[t]=\left(\tilde{\lambda}_{1}+\tilde{u}_{1}(t), \tilde{\lambda}_{2}+\tilde{u}_{2}(t), \ldots, \tilde{\lambda}_{N}+\tilde{u}_{N}(t)\right)^{\prime}$ will be a solution of problem (9)-(11).

Appearance of the initial conditions $u_{r}[(r-1) h]=0, r=\overline{1, N}$, allows us to determine functions $u_{r}(t)$, $r=\overline{1, N}$, from the systems of integral equations for fixed values $\lambda=\left(\lambda_{1}, \lambda_{2}, \ldots, \lambda_{N}\right)^{\prime}$ :

$$
u_{r}(t)=\int_{(r-1) h}^{t} \sum_{j=1}^{N} \int_{(j-1) h}^{j h} \hat{K}_{1}(\tau, s)\left[u_{j}(s)+\lambda_{j}\right] d s d \tau+\int_{(r-1) h}^{t} \hat{f}(\tau) d \tau, \quad t \in[(r-1) h, r h) .
$$

From (16) defining $\lim _{t \rightarrow N h-0} u_{N}(t), \lim _{t \rightarrow s h-0} u_{s}(t), s=\overline{1, N}-1$, putting the corresponding expressions into the conditions (14), (15), and multiplying both sides of (14) to $h>0$, we get the system of linear equations concerning to the unknown parameters $\lambda_{r}, r=\overline{1, N}$ :

$$
\begin{gathered}
h B \lambda_{1}+h C \lambda_{N}+h C \int_{(N-1) h}^{N h} \sum_{j=1}^{N} \int_{(j-1) h}^{j h} \hat{K}_{1}(\tau, s) \lambda_{j} d s d \tau= \\
=h d-h C \int_{(N-1) h}^{N h} \hat{f}(\tau)(\tau) d \tau-h C \int_{(N-1) h}^{N h} \sum_{j=1}^{N} \int_{(j-1) h}^{j h} \hat{K}_{1}(\tau, s) u_{j}(s) d s d \tau \\
\lambda_{s}+\int_{(s-1) h}^{s h} \sum_{j=1}^{N} \int_{(j-1) h}^{j h} \hat{K}_{1}(\tau, s) \lambda_{j} d s d \tau-\lambda_{s+1}= \\
=-\int_{(s-1) h}^{s h} \sum_{j=1}^{N} \int_{(j-1) h}^{j h} \hat{K}_{1}(\tau, s) u_{j}(s) d s d \tau-\int_{(s-1) h}^{s h} \hat{f}(\tau) d \tau, \quad s=\overline{1, N-1 .}
\end{gathered}
$$

We denote the $n N \times n N$ dimensional matrix corresponding to the left side of the system of linear equations (17), (18) by $Q(h)$. Then the system of linear equations $(17),(18)$ can be written in the form:

$$
Q(h) \lambda=-F(h)-G(u, h), \lambda \in R^{n N},
$$

where

$$
\begin{gathered}
F(h)=\left(-h d+h C \int_{(N-1) h}^{N h} f_{1}(\tau) d \tau, \int_{0}^{h} f_{1}(\tau) d \tau, \ldots, \int_{(N-2) h}^{(N-1) h} f_{1}(\tau) d \tau\right), \\
G(u, h)=\left(h C \int_{(N-1) h}^{N h} \sum_{j=1}^{N} \int_{(j-1) h}^{j h} K_{1}(\tau, s) u_{j}(s) d s d \tau, \int_{0}^{h} \sum_{j=1}^{N} \int_{(j-1) h}^{j h} K_{2}(\tau, s) u_{j}(s) d s d \tau, \ldots,\right. \\
\left.\int_{(N-2) h}^{(N-1) h} \sum_{j=1}^{N} \int_{(j-1) h}^{j h} K(\tau, s) u_{j}(s) d s d \tau\right) .
\end{gathered}
$$

Therefore, to find unknown pairs $(\lambda, u[t])$, solutions of the problem (12)-(15)... we have a closed system of equations (16), (19). We find solution of the multipoint boundary value problem (12)-(15) as a limit of the sequence of pairs $\left(\lambda^{\prime(k)}, u^{(k)}[t]\right), k=0,1,2, \ldots$, defined by the following algorithm:

Step 0. a) Assuming, that the matrix $Q(h)$ is invertible, from the equation $Q(h) \lambda=-F(h)$ we define the initial approximation by the parameter $\lambda^{(0)}=\left(\lambda_{1}^{(0)}, \lambda_{2}^{(0)}, \ldots, \lambda_{N}^{(0)}\right) \in R^{n N}: \lambda^{(0)}=-[Q(h)]^{-1} F(h)$.

b) Putting the found $\lambda_{r}^{(0)}, r=\overline{1, N}$ into the right side of the system of integral-differential equations (12) and solving the special Cauchy problem with conditions (13), we find $u^{(0)}[t]=\left(u_{1}^{(0)}(t), u_{2}^{(0)}(t), \ldots, u_{N}^{(0)}(t)\right)^{\prime}$.

Step 1. a) Putting the found values $u_{r}^{(0)}(t), \quad r=\overline{1, N}$ into the right side of (19), from the equation $[Q(h)] \lambda=-F(h)-G\left(u^{(0)}, h\right)$ we define $\lambda^{(1)}=\left(\lambda_{1}^{(1)}, \lambda_{2}^{(1)}, \ldots \lambda_{N}^{(1)}\right)$. 
b) Putting the found $\lambda_{r}^{(1)}, r=\overline{1, N}$ into the right side of the system of integral-differential equations (12) and solving the special Cauchy problem with conditions (13), we find $u^{(1)}[t]=\left(u_{1}^{(1)}(t), u_{2}^{(1)}(t), \ldots, u_{N}^{(1)}(t)\right)^{\prime}$ and etc.

Continuing the process, at the $k$-step of the algorithm we find the system of pairs $\left(\lambda^{(k)}, u^{(k)}[t]\right), k=0,1,2, \ldots$.

Unknown functions $u[t]=\left(u_{1}(t), u_{2}(t), \ldots, u_{N}(t)\right)$ are determined from the special Cauchy problem for systems of integral-differential equations (12) with initial conditions (13). In contrast to the Cauchy problem for ordinary differential equations, the special Cauchy problem for systems of integral-differential equations is not always solvable.

Sufficient conditions for unique solvability of the special Cauchy problem (12), (13) for known values of the parameters $\lambda$ are established by

Theorem 1 . Let the partition step $h=T / N$ satisfy the inequality

$$
\delta(h)=\beta T h<1,
$$

where $\beta=\max _{(t, s) \in[0, T] \times[0, T]}\left\|\hat{K}_{1}(t, s)\right\|$.

Then, the special Cauchy problem (12), (13) has a unique solution.

Sufficient conditions for feasibility and convergence of the proposed algorithm, as well as existence of a unique solution to problem (1), (2) are established by

Theorem 2. Let the following conditions hold:

1) Condition $A$,

2) matrix $\operatorname{diag}\left(1-a_{1}^{2}, 1-a_{2}^{2}, \ldots, 1-a_{n}^{2}\right)$ is invertible,

3) conditions of Theorem 1 hold,

4) matrix $Q(h)$ is invertible and the following inequalities hold:

$$
\begin{gathered}
\left\|[Q(h)]^{-1}\right\| \leq \gamma(h), \\
q(h)=\frac{\delta(h)}{1-\delta(h)} \gamma(h) \max (1, h\|C\|) \delta(h)<1 .
\end{gathered}
$$

Then the two-point boundary value problem for systems of integral-differential equations (1), (2) has a unique solution.

Proof of Theorem 1 and Theorem 2 is similar to the scheme of the proof of Theorem 1 and Theorem 3 from [16] and is carried out according to the above algorithm, taking into account the specifics of the system (1).

In [5], necessary and sufficient conditions for unique solvability of a linear boundary value problem for the following systems of differential equations were obtained

$$
\begin{gathered}
\frac{d x}{d t}=\int_{0}^{T} K(t, s) x(s) d s+f(t), \quad t \in[0, T], \\
B x(0)+C x(T)=d, \quad d \in R^{n} .
\end{gathered}
$$

Theorem ([8; 1216]). For unique solvability of the problem $(14),(15)$ it is necessary and sufficient existence of $h \in\left(0, h_{0}\right]: N h=T$, where the matrix $Q_{*, *}(h)$ is invertible.

The above theorem implies

Corollary. For unique solvability of the problem (1), (2) it is necessary and sufficient the conditions 1 and 2 of Theorem 2, as well as existence of $h \in\left(0, h_{0}\right]: N h=T$, where the matrix $Q_{*, *}(h)$ is invertible.

Where $h_{0}$ is defined from the condition $q\left(h_{0}\right)=\beta T h_{0}<1$, and the matrix $Q_{*, *}(h)$ is defined in the same way as in [8].

\section{Acknowledgments}

This research was funded by the Science Committee of the Ministry of Education and Science of the Republic of Kazakhstan (Grant No AP09259137 and AP08956307) 


\section{References}

1 Brunner H. Collocation Methods for Volterra Integral and Related Functional Equations / H. Brunner. - Cambridge: Cambridge University Press, 2004.

2 Dzhumabaev D. S. One approach to solve a nonlinear boundary value problem for the Fredholm integrodifferential equation / D. S. Dzhumabaev, S. T. Mynbayeva // Bulletin of the Karaganda universityMathematics. - 2020. - № 1(97). - P. 27-36.

$3 \mathrm{Du}$ H. Reproducing Kernelmethod for solving Fredholm integro-differential equations withweakly singularity / H. Du, G. Zhao, C. Zhao // J. Comput. Appl. Math. - 2014. - 255. - P. 122-132.

4 Maleknejad K. An efficient numerical approximation for the linear Fredholm integro-differential equations based on Cattani's method / K. Maleknejad, M. Attary // Commun Nonlinear Sci Numer Simulat. 2011. - 16. - P. 2672-2679.

5 Molabahrami A. Direct computation method for solving a general nonlinear Fredholm integro-differential equation under the mixed conditions: degenerate and non-degenerate Kernels / A. Molabahrami // J. Comput. Appl. Math. - 2015. - 282. - P. 34-43.

6 Wazwaz A.M. Linear and Nonlinear Integral Equations: Methods and Applications / A.M. Wazwaz. Beijing and Springer-Verlag: Higher Education Press, 2011.

7 Джумабаев Д.С. Признаки однозначной разрешимости линейной краевой задачи для обыкновенного дифференциального уравнения / Д.С. Джумабаев // Журн. вычисл. мат. и мат. физ. - 1989. - 29(1). - C. 50-66.

8 Джумабаев Д.С. Об одном методе решения линейной краевой задачи для интегро-дифференциального уравнения / Д.С. Джумабаев // Журн. вычисл. мат. и мат. физ. - 2010. - 50(7). - C. $1209-1221$.

9 Dzhumabaev D.S. An algorithm for solving a linear two-point boundary value problem for an integrodifferential equation / D.S. Dzhumabaev // Computational Mathematics and Mathematical Physics. 2013. - Vol. 53. - No. 6. - P. 736-758.

10 Dzhumabaev D.S. On one approach to solve the linear boundary value problems for Fredholm integrodifferential equations / D.S. Dzhumabaev // Journal of Computational and Applied Mathematics. - 2016. - Vol. 294. - No. 2. - P. 342-357.

11 Dzhumabaev D.S. Computational methods of solving the boundary value problems for the loaded differential and Fredholm integro-differential equations / D.S. Dzhumabaev // Mathematical Methods in the Applied Sciences. - 2018. - Vol. 41. - No. 4. - P. 1439-1462.

12 Орумбаева Н.Т. Об алгоритмах нахождения решения начально-краевой задачи для дифференциальных уравнений в частных производных / Н.Т. Орумбаева // Вестн. Караганд. ун-та. Сер. Математика. - 2016. - № 2(82). - С. 107-112.

13 Назарова К.Ж. Существование изолированного решения нелинейной двухточечной краевой задачи и её свойства / К.Ж. Назарова // Вестн. Караганд. ун-та. Сер. Математика. - 2016. - № 1(81). C. $51-61$.

14 Литвинчук Г.С. Краевые задачи и сингулярные интегральные уравнения со сдвигом / Г.С. Литвинчук. - М.: Гл. ред. физ.-мат. лит. изд-ва «Наука», 1977.

15 Карапетянц Н.К. Уравнения с инволютивными операторами и их приложения / Н.К. Карапетянц, С.Г. Самко. - Ростов н/Д.: Изд-во Ростов. гос. ун-та, 1988. - 201 с.

16 Бакирова Э.А. Корректная разрешимость линейной двухточечной краевой задачи для систем интегро-дифференциальных уравнений: автореф. дис. ... канд. физ.-мат. наук: 01.01 .02 - «Дифференциальные уравнения» / Э.А. Бакирова. - Алматы, 2006. 


\title{
Инволюциялы функционалды-дифференциалдық теңдеулер үшін шеттік есептің бірмәнді шешілімділігі
}

\begin{abstract}
Мақалада теңдеудің оң жағының құрамында интеграл таңбасының астында ізделінді функциядан туындысы бар инволютивті түрлендірумен Фредгольм типтес интегралдық-дифференциалдық теңдеулер жүйесі үшін шеттік есеп қарастырылды. Инволютивті түрлендірудің қасиетін пайдаланудан бастапқы есеп оң жақ бөлігінде интеграл таңбасының астында ізделінді функциядан туындысы бар интегралдық-дифференциалдық теңдеу үшін шеттік есепке және интегралдық теңдеудің ядросы $\tilde{K}_{2}(t, s)$-ке (ізделінді функциядан туындысы бар интегралдық теңдеудің ядросы) байланысты резольвентасы бар деп жорамалдап, интегралдық-дифференциалдық теңдеу оң жақ бөлігінде ізделінді функциядан туындысы жоқ теңдеуге келтіріледі. Алынған шеттік есеп профессор Д.С. Джумабаев ұсынған параметрлеу әдісімен шығарылған. Осы әдістің негізінде есеп жаңа енгізілген функцияларға байланысты арнайы Коши есебін және енгізілген параметрлерге байланысты сызықты алгебралық теңдеулер жүйесі шешуге келтіріледі. Есептің шешімін табу алгоритмі ұсынылған. Белгілі болғандай, жәй дифференциалдық теңдеулер үшін Коши есебіне қарағанда интегралдық-дифференциалдық теңдеулер жүйесі үшін арнайы Коши есебінің барлық уақытта шешімі бар бола бермейді. Профессор Д.С. Джумабаевтың алған нәтижелерін қолдана отырып, арнайы Коши есебінің бірмәнді шешілімділігінің қажетті шарттары тағайындалды.
\end{abstract}

Kiлm сөздер: интегралдық-дифференциалдық теңдеулер жүйесі, шеттік шарттар, параметрлеу әдісі, интегралдық теңдеу, резольвента, инволюция, бірмәнді шешілімділік, арнайы Коши есебі.

\author{
К.Ж. Назарова, К.И. Усманов
}

Международный казахско-турещкий университет им. Ходжи Ахмета Яссави, Туркестан, Казахстан

\section{Однозначная разрешимость краевой задачи для функционально-дифференциальных уравнений с инволюцией}

В статье рассмотрена краевая задача для систем интегро-дифференциальных уравнений типа Фредгольма с инволютивным преобразованием, содержащая в правой части производную от искомой функций под знаком интеграла. Пользуясь свойством инволютивного преобразования, задача сведена к краевой задаче для систем интегро-дифференциальных уравнений, содержащей в правой части производную от искомой функции под знаком интеграла. Предполагая существование резольвенты интегрального уравнения относительно ядра $\tilde{K}_{2}(t, s)$ (ядро интегрального уравнения, которое содержит производную от искомой функции) и используя резольвенту, интегро-дифференциальное уравнение сведено к уравнению, не содержащему производную от искомой функции в правой части интегро-дифференциального уравнения. Далее полученная краевая задача решается методом параметризации, предложенным профессором Д. Джумабаевым. На основе данного метода задача сведена к решению специальной задачи Коши относительно введенных новых функций и к решению систем линейных алгебраических уравнений относительно введенных параметров. Предложен алгоритм нахождения решений. Как известно, в отличие от задачи Коши для обыкновенных дифференциальных уравнений, специальная задача Коши для систем интегро-дифференциальных уравнений не всегда разрешима. Авторами были установлены необходимые условия однозначной разрешимости специальной задачи Коши. Используя результаты, полученные профессором Д. Джумабаевым, были найдены необходимые и достаточные условия однозначной разрешимости исходной задачи.

Ключевые слова: система интегро-дифференциальных уравнений, краевые условия, метод параметризации, интегральное уравнение, резольвента, инволюция, однозначная разрешимость, специальная задача Коши. 


\section{References}

1 Brunner, H. (2004). Collocation Methods for Volterra Integral and Related Functional Equations. Cambridge: Cambridge University Press.

2 Dzhumabaev, D.S., \& Mynbayeva, S.T. (2020). One approach to solve a nonlinear boundary value problem for the Fredholm integro-differential equation. Bulletin of the Karaganda university-Mathematics, 1(97), 27-36.

3 Du, H., Zhao, G., \& Zhao, C. (2014). Reproducing Kernelmethod for solving Fredholm integro-differential equations withweakly singularity. J. Comput. Appl. Math., 255, 122-132.

4 Maleknejad, K, \& Attary, M. (2011). An efficient numerical approximation for the linear Fredholm integrodifferential equations based on Cattani's method. Commun Nonlinear Sci Numer Simulat, 16, $2672-2679$.

5 Molabahrami, A. (2015). Direct computation method for solving a general nonlinear Fredholm integrodifferential equation under the mixed conditions: degenerate and non-degenerate Kernels. J. Comput. Appl. Math., 282, 34-43.

6 Wazwaz, A.M. (2011). Linear and Nonlinear Integral Equations: Methods and Applications. Beijing and Springer-Verlag: Higher Education Press.

7 Dzhumabaev, D.S. (1989). Priznaki odnoznachnoi razreshimosti lineinoi kraevoi zadachi dlia obyknovennogo differentsialnogo uravneniia [Criteria for the unique solvability of a linear boundary-value problem for an ordinary differential equation]. Zhurnal vychislitelnoi matematiki i matematicheskoi fiziki - Journal of Computational Mathematics and Mathematical Physics, 29, 1, 50-66 [in Russian].

8 Dzhumabaev, D.S. (2010). Ob odnom metode resheniia lineinoi kraevoi zadachi dlia integro-differentsialnogo uravneniia [A method for solving a linear boundary value problem for an integro-differential equation]. Zhurnal vychislitelnoi matematiki i matematicheskoi fiziki - Journal of Computational Mathematics and Mathematical Physics, 50, 7, 1209-1221 [in Russian].

9 Dzhumabaev, D.S. (2013). An algorithm for solving a linear two-point boundary value problem for an integrodifferential equation. Computational Mathematics and Mathematical Physics, 53, 6, 736-758.

10 Dzhumabaev, D.S. (2016). On one approach to solve the linear boundary value problems for Fredholm integro-differential equations. Journal of Computational and Applied Mathematics, 294, 2, 342-357.

11 Dzhumabaev, D.S. (2018). Computational methods of solving the boundary value problems for the loaded differential and Fredholm integro-differential equations. Mathematical Methods in the Applied Sciences, 41, 4, 1439-1462.

12 Orumbaeva, N.T. (2016). Ob algoritmakh nakhozhdeniia resheniia nachalno-kraevoi zadachi dlia differentsialnykh uravnenii $\mathrm{v}$ chastnykh proizvodnykh [Algorithms for finding a solution to the initial boundary value problems for differential equations in partial derivatives]. Vestnik Karagandinskogo universiteta. Seriia Matematika - Bulletin of the Karaganda University. Mathematics series, 2(82), 107-112 [in Russian].

13 Nazarova, K.Zh. (2016). Sushchestvovanie izolirovannogo resheniia nelineinoi dvukhtochechnoi kraevoi zadachi i ee svoistva [The existence of isolated solutions of nonlinear two-point boundary value problem and their properties]. Vestnik Karagandinskogo universiteta. Seriia Matematika - Bulletin of the Karaganda University. Mathematics series, 1(81), 51-61 [in Russian].

14 Litvinchuk, G.S. (1977). Kraevye zadachi i singuliarnye integralnye uravneniia so sdvigom [Boundary value problems and singular integral equations with a shift]. Moscow: Glavnaia redaktsiia fiziko-matematicheskoi literatury «Nauka» [in Russian].

15 Karapetiants, N.K., \& Samko, S.G. (1988). Uravneniia s involiutivnymi operatorami i ikh prilozheniia [Equations with involutive operators and their applications]. Rostov-na-Donu: Izdatelstvo Rostovskogo gosudarstvennogo universiteta [in Russian].

16 Bakirova, E.A. (2006). Korrektnaia razreshimost lineinoi dvukhtochechnoi kraevoi zadachi dlia sistem integro-differentsialnykh uravnenii [Correct solvability of a linear two-point boundary value problem for systems of integro-differential equations]. Extended abstract of candidate's thesis. Almaty: IM MON RK [in Russian]. 


\author{
I.N. Parasidis*, E. Providas \\ University of Thessaly, Larissa, Greece \\ (E-mail: paras@uth.gr,providas@uth.gr)
}

\title{
Factorization method for solving nonlocal boundary value problems in Banach space
}

\begin{abstract}
This article deals with the factorization and solution of nonlocal boundary value problems in a Banach space of the abstract form

$$
B_{1} u=\mathcal{A} u-S \Phi(u)-G \Psi\left(A_{0} u\right)=f, \quad u \in D\left(B_{1}\right),
$$

where $\mathcal{A}, A_{0}$ are linear abstract operators, $S, G$ are vectors of functions, $\Phi, \Psi$ are vectors of linear bounded functionals, and $u, f$ are functions. It is shown that the operator $B_{1}$ under certain conditions can be factorized into a product of two simpler lower order operators as $B_{1}=B B_{0}$. Then the solvability and the unique solution of the equation $B_{1} u=f$ easily follow from the solvability conditions and the unique solutions of the equations $B v=f$ and $B_{0} u=v$. The universal technique proposed here is essentially different from other factorization methods in the respect that it involves decomposition of both the equation and boundary conditions and delivers the solution in closed form. The method is implemented to solve ordinary and partial Fredholm integro-differential equations.
\end{abstract}

Keywords: boundary value problems, nonlocal conditions, factorization, linear operators, integro-differential equations, closed-form solutions.

\section{Introduction}

Let $X$ be a complex Banach space and $X^{*}$ the adjoint space of $X$, i.e., the set of all complex-valued linear bounded functionals $\phi$ on $X$. Let $\mathcal{A}, A_{0}: X \rightarrow X$ be linear operators with boundary conditions incorporated, $\Phi=\operatorname{col}\left(\phi_{1}, \phi_{2}, \ldots, \phi_{m}\right), \Psi=\operatorname{col}\left(\psi_{1}, \psi_{2}, \ldots, \psi_{m}\right)$ vectors of linear bounded functionals $\phi_{i}, \psi_{i}, i=1,2, \ldots, m$, and $S\left(s_{1}, s_{2}, \ldots, s_{m}\right), G=\left(g_{1}, g_{2}, \ldots, g_{m}\right)$ vectors of functions $s_{i}, g_{i} \in X, i=1,2, \ldots, m$. Let the operator $B_{1}: X \rightarrow X$ be defined by

$$
B_{1}=\mathcal{A}-S \Phi-G \Psi\left(A_{0}\right)
$$

and consider the boundary value problem

$$
B_{1} u=\mathcal{A} u-S \Phi(u)-G \Psi\left(A_{0} u\right)=f, \quad u \in D\left(B_{1}\right)
$$

where $f \in X$ is a given forcing function and $u$ is the unknown function.

The primary objective of the paper is to establish factorization conditions under which this problem can be decomposed into two simpler lower order boundary value problems and derive the unique solution in closed form. The second goal is to implement this procedure to solve boundary value problems for ordinary and partial Fredholm integro-differential equations with nonlocal boundary conditions. In this case $B_{1}$ is an integrodifferential operator, $\mathcal{A}$ is a differential operator of order $n$ with nonlocal boundary conditions incorporated, and the functionals $\phi_{i}, \psi_{i}, i=1, \ldots, m$ are integrals with constant limits.

Integro-differential equations model many situations in biology, physics, economics, engineering and applied mathematics. Boundary value problems involving an integro-differential equation and nonlocal boundary conditions are very difficult to solve analytically and therefore very often numerical methods are employed. Factorization methods, where they can be applied, can reduce the problem to simpler lower order problems which can be solved and thus construct the solution of the initial complex problem [1-20].

The novelty of the factorization method presented here differs from other factorization methods in the literature in the respect that it involves decomposition of both the equation and boundary conditions and

\footnotetext{
${ }^{*}$ Corresponding author.

E-mail: paras@uth.gr
} 
delivers the solution in closed form. The technique is new development in Banach spaces and an extension of a procedure used successfully by the authors to solve various other boundary value problems [21-24] and [25-27].

The method is simple to program to any Computer Algebra System.

The rest of the paper is organized as follows. In Section 1 some preliminary results are quoted. In Section 2 the solvability, uniqueness and decomposition conditions are established and the factorization solution method is explicated. In Section 3 two example problems are solved to show the implementation and efficiency of the method.

\section{Preliminaries}

Let $X, Y$ be complex Banach space and $A: X \rightarrow Y$ a linear operator with $D(A)$ and $R(A)$ denoting its domain and range, respectively. We recall that $A$ is said to be injective (or uniquely solvable) if for all $u_{1}, u_{2} \in D(A)$ such that $A u_{1}=A u_{2}$, follows that $u_{1}=u_{2}$; alternatively, $A$ is injective if and only if ker $A=\{0\}$. The operator $A$ is called surjective (or everywhere solvable) if $R(A)=Y$. The operator $A$ is called bijective if $A$ is both injective and surjective. Lastly, $A$ is said to be correct if $A$ is bijective and its inverse $A^{-1}$ is bounded on $Y$. The problem $A u=f$ is called correct if the operator $A$ is correct.

An operator $B_{1}: X \rightarrow X$ is said to be factorable if there exist two operators $B_{0}, B: X \rightarrow X$ such that $B_{1}$ can be written as a product $B_{1}=B B_{0}$. In this case, $B B_{0}$ is a factorization (decomposition) of $B_{1}$.

Throughout the paper, we will use the notation $\Phi(g)$ to denote the $m \times m$ matrix whose $i, j$-th entry $\phi_{i}\left(g_{j}\right)$ is the value of the functional $\phi_{i}$ on element $g_{j}$, where $i, j=1, \ldots, m$. Note that $\Phi(g C)=\Phi(g) C$, where $C$ is a $m \times k$ constant matrix. We will also denote by $\mathbf{c}$ the column vector $\mathbf{c}=\operatorname{col}\left(c_{1}, \ldots, c_{m}\right)$ and by $0_{m}, I_{m}$ the zero and identity $m \times m$ matrices, respectively.

We recall Corollary 3.11 from [25] which will need to prove the theorems below.

Corollary 1. Let $A$ be a correct operator on a Banach space $X$ and the components of the vectors $G=\left(g_{1}, \ldots, g_{m}\right)$ and $F=\operatorname{col}\left(F_{1}, \ldots F_{m}\right)$ are arbitrary elements of $X$ and $X^{*}$, respectively. Then the operator $B: X \rightarrow X$ defined by

$$
B u=A u-G F(A u)=f, \quad D(B)=D(A), \quad f \in X
$$

is correct if and only if

$$
\operatorname{det} L=\operatorname{det}\left[I_{m}-F(G)\right] \neq 0 \text {. }
$$

If $B$ is correct, then the unique solution of (1) for every $f \in X$ is given by

$$
u=B^{-1} f=A^{-1} f+A^{-1} G\left[I_{m}-F(G)\right]^{-1} F(f) .
$$

The following theorem is the generalization of Theorem 1 in [28] and here we prove it without requiring the correctness of the operator $A$ and the linear independence of the components of the functional vector $\Psi=\operatorname{col}\left(\psi_{1}, \ldots, \psi_{m}\right)$.

Theorem 2. Let $X, Y$ and $Z$ be Banach spaces and $A: X \rightarrow Y$ be a linear injective operator with $D(A) \subset Z \subseteq X$. Further let the vector $G=\left(g_{1}, \ldots, g_{m}\right) \in Y^{m}$ and the column vector $\Psi=\operatorname{col}\left(\psi_{1}, \ldots, \psi_{m}\right)$, where $\psi_{1}, \ldots, \psi_{m} \in Z^{*}$. Then:

(i) The operator $B: X \rightarrow Y$ defined by

$$
B u=A u-G \Psi(u)=f, \quad D(B)=D(A), \quad f \in X,
$$

is injective if and only if

$$
\operatorname{det} W=\operatorname{det}\left[I_{m}-\Psi\left(A^{-1} G\right)\right] \neq 0 .
$$

(ii) If $B$ is injective and $A$ is bijective, then $B$ is bijective and for any $f \in Y$, the unique solution of (4) is given by

$$
u=B^{-1} f=A^{-1} f+A^{-1} G W^{-1} \Psi\left(A^{-1} f\right) .
$$

(iii) If $B$ is injective and $A$ is correct, then $B$ is correct.

Proof. (i) The sufficient injectiveness condition of the operator $B$ is proved as in [28].

Now, we prove the converse statement "if the operator $B$ is injective, then $\operatorname{det} W \neq 0$ " or equivalently "if $\operatorname{det} W=0$, then the operator $B$ is not injective". Suppose $\operatorname{det} W=0$. Then there exists a nonzero vector $\mathbf{c}=\operatorname{col}\left(c_{1}, \ldots, c_{m}\right)$ such that $W \mathbf{c}=\mathbf{0}$. Consider the element $u_{0}=A^{-1} G \mathbf{c}$. This element is nonzero, because otherwise we would have

$$
W \mathbf{c}=\left[I_{m}-\Psi\left(A^{-1} G\right)\right] \mathbf{c}=\mathbf{c}-\Psi\left(A^{-1} G \mathbf{c}\right)=\mathbf{c} \neq \mathbf{0},
$$


which is a contradiction. Further,

$$
B u_{0}=A u_{0}-G \Psi\left(u_{0}\right)=G \mathbf{c}-G \Psi\left(A^{-1} G\right) \mathbf{c}=G\left[I_{m}-G \Psi\left(A^{-1} G\right)\right] \mathbf{c}=G W \mathbf{c}=0,
$$

which means that $u_{0} \in \operatorname{ker} B$ and thus $B$ is not injective.

(ii) Let $B$ is injective and $A$ is bijective. Then (5) holds ( $\operatorname{det} W \neq 0$ ) and for any $f \in Y$ from (4) follows that

$$
u=A^{-1} G \Psi(u)+A^{-1} f
$$

and

$$
\begin{gathered}
\Psi(u)=\Psi\left(A^{-1} G\right) \Psi(u)+\Psi\left(A^{-1} f\right), \\
{\left[I_{m}-\Psi\left(A^{-1} G\right)\right] \Psi(u)=\Psi\left(A^{-1} f\right),} \\
\Psi(u)=\left[I_{m}-\Psi\left(A^{-1} G\right)\right]^{-1} \Psi\left(A^{-1} f\right) .
\end{gathered}
$$

Substituting (8) into (7), we obtain the unique solution (6). Since this solution is given for arbitrary $f \in Y$, then $R(B)=Y$, i.e., $B$ is surjective. Hence $B$ is a bijective operator.

(iii) If $B$ is injective and $A$ is correct, then from (6) follows that $B^{-1}$ is bounded since $A^{-1}$ and $\Psi$ are bounded. Hence $B$ is correct.

\section{Main results}

Theorem 3. Let $X$ and $Z_{0}, Z$ be Banach spaces, $Z_{0}, Z \subseteq X$, the vectors $G_{0}=\left(g_{10}, \ldots, g_{m 0}\right), G=\left(g_{1}, \ldots, g_{m}\right)$, $S=\left(s_{1}, \ldots, s_{m}\right) \in X^{m}$, the components of the column vectors $\Phi=\operatorname{col}\left(\phi_{1}, \ldots, \phi_{m}\right)$ and $\Psi=\operatorname{col}\left(\psi_{1}, \ldots, \psi_{m}\right)$ belong to $Z_{0}^{*}$ and $Z^{*}$, respectively, and the operators $B_{0}, B, B_{1}: X \rightarrow X$ be defined by

$$
\begin{gathered}
B_{0} u=A_{0} u-G_{0} \Phi(u)=f, \quad D\left(B_{0}\right)=D\left(A_{0}\right) \subset Z_{0}, \\
B u=A u-G \Psi(u)=f, \quad D(B)=D(A) \subset Z, \\
B_{1} u=A A_{0} u-S \Phi(u)-G \Psi\left(A_{0} u\right)=f, \quad D\left(B_{1}\right)=D\left(A A_{0}\right),
\end{gathered}
$$

where $A_{0}$ and $A$ are linear correct operators on $X$ and $G_{0} \in D(A)^{m}$. Then the following statements are satisfied:

(i) If

$$
S \in R(B)^{m} \quad \text { and } \quad S=B G_{0}=A G_{0}-G \Psi\left(G_{0}\right)
$$

then the operator $B_{1}$ can be factorized as $B_{1}=B B_{0}$.

(ii) If (12) holds, then the operator $B_{1}=B B_{0}$ is correct if and only if the operators $B_{0}$ and $B$ are correct which means that

$$
\operatorname{det} L_{0}=\operatorname{det}\left[I_{m}-\Phi\left(A_{0}^{-1} G_{0}\right)\right] \neq 0 \quad \text { and } \quad \operatorname{det} L=\operatorname{det}\left[I_{m}-\Psi\left(A^{-1} G\right)\right] \neq 0,
$$

and the unique solution of (11) is

$$
\begin{aligned}
u=B_{1}^{-1} f=A_{0}^{-1} A^{-1} f+ & {\left[A_{0}^{-1} A^{-1} G+A_{0}^{-1} G_{0} L_{0}^{-1} \Phi\left(A_{0}^{-1} A^{-1} G\right)\right] L^{-1} \Psi\left(A^{-1} f\right) } \\
& +A_{0}^{-1} G_{0} L_{0}^{-1} \Phi\left(A_{0}^{-1} A^{-1} f\right) .
\end{aligned}
$$

Proof. (i) Taking into account that $G_{0} \in D(A)^{m}$ and (9)-(11) we get

$$
\begin{gathered}
D\left(B B_{0}\right)=\left\{u \in D\left(B_{0}\right): B_{0} u \in D(B)\right\} \\
=\left\{u \in D\left(A_{0}\right): A_{0} u-G_{0} \Phi(u) \in D(A)\right\} \\
=\left\{u \in D\left(A_{0}\right): A_{0} u \in D(A)\right\}=D\left(A A_{0}\right)=D\left(B_{1}\right) .
\end{gathered}
$$

So $D\left(B_{1}\right)=D\left(B B_{0}\right)$. Let $y=B_{0} u$. Then for each $u \in D\left(A A_{0}\right)$ since (10) and (9) we have

$$
\begin{gathered}
B B_{0} u=B y=A y-G \Psi(y) \\
=A\left[A_{0} u-G_{0} \Phi(u)\right]-G \Psi\left(A_{0} u-G_{0} \Phi(u)\right) \\
=A A_{0} u-A G_{0} \Phi(u)-G \Psi\left(A_{0} u\right)+G \Psi\left(G_{0}\right) \Phi(u)
\end{gathered}
$$




$$
\begin{gathered}
=A A_{0} u-\left[A G_{0}-G \Psi\left(G_{0}\right)\right] \Phi(u)-G \Psi\left(A_{0} u\right) \\
=A A_{0} u-B G_{0} \Phi(u)-G \Psi\left(A_{0} u\right),
\end{gathered}
$$

where the relation $B G_{0}=A G_{0}-G \Psi\left(G_{0}\right)$ follows from (10) if instead of $u$ we take $G_{0}$. By comparing (15) with (11) it is easy to verify that $B_{1} u=B B_{0} u$ for each $u \in D\left(A A_{0}\right)$ if a vector $S$ satisfies (12).

(ii) Let the operator $B_{1}$ be defined by (11), where $S=B G_{0}$. Then Equation (11) can be equivalently presented in the matrix form:

$$
B_{1} u=A A_{0} u-\left(B G_{0}, G\right)\left(\begin{array}{c}
\Phi\left(A_{0}^{-1} A^{-1} A A_{0} u\right) \\
\Psi\left(A^{-1} A A_{0} u\right)
\end{array}\right)=f
$$

or

$$
B_{1} u=\mathcal{A} u-\mathcal{G} \mathcal{F}(\mathcal{A} u)=f, \quad D\left(B_{1}\right)=D(\mathcal{A}),
$$

where $\mathcal{A}=A A_{0}, \mathcal{G}=\left(B G_{0}, G\right), \mathcal{F}=\operatorname{col}(\hat{\Phi}, \hat{\Psi})$, and

$$
\mathcal{F}(v)=\left(\begin{array}{c}
\hat{\Phi}(v) \\
\hat{\Psi}(v)
\end{array}\right)=\left(\begin{array}{c}
\Phi\left(A_{0}^{-1} A^{-1} v\right) \\
\Psi\left(A^{-1} v\right)
\end{array}\right) .
$$

Notice that the operator $\mathcal{A}=A A_{0}$ is correct, because of $A$ and $A_{0}$ are correct, and that the vector $\mathcal{F}$ is bounded, since the vector $\hat{\Phi}$ (resp. $\hat{\Psi}$ ) is bounded as a superposition of a bounded functional $\Phi$ (resp. $\Psi$ ) and a bounded operator $A_{0}^{-1} A^{-1}$ (resp. $A^{-1}$ ). Then we apply Corollary 1 . In accordance to $(2),(3)$, the operator $B_{1}$ is correct if and only if

$$
\begin{gathered}
\operatorname{det} L_{1}=\operatorname{det}\left[I_{2 m}-\mathcal{F}(\mathcal{G})\right]=\operatorname{det}\left[\left(\begin{array}{cc}
I_{m} & 0_{m} \\
0_{m} & I_{m}
\end{array}\right)-\left(\begin{array}{cc}
\hat{\Phi}\left(B G_{0}\right) & \hat{\Phi}(G) \\
\hat{\Psi}\left(B G_{0}\right) & \hat{\Psi}(G)
\end{array}\right)\right] \\
=\operatorname{det}\left(\begin{array}{cc}
I_{m}-\hat{\Phi}\left(A G_{0}-G \Psi\left(G_{0}\right)\right) & -\hat{\Phi}(G) \\
-\hat{\Psi}\left(A G_{0}-G \Psi\left(G_{0}\right)\right) & I_{m}-\hat{\Psi}(G)
\end{array}\right) \\
=\operatorname{det}\left(\begin{array}{cc}
I_{m}-\Phi\left(A_{0}^{-1} G_{0}-A_{0}^{-1} A^{-1} G \Psi\left(G_{0}\right)\right) & -\Phi\left(A_{0}^{-1} A^{-1} G\right) \\
-\Psi\left(G_{0}-A^{-1} G \Psi\left(G_{0}\right)\right) & I_{m}-\Psi\left(A^{-1} G\right)
\end{array}\right) \\
=\operatorname{det}\left(\begin{array}{cc}
I_{m}-\Phi\left(A_{0}^{-1} G_{0}\right)+\Phi\left(A_{0}^{-1} A^{-1} G\right) \Psi\left(G_{0}\right) & -\Phi\left(A_{0}^{-1} A^{-1} G\right) \\
-\Psi\left(G_{0}\right)+\Psi\left(A^{-1} G\right) \Psi\left(G_{0}\right) & I_{m}-\Psi\left(A^{-1} G\right)
\end{array}\right) \neq 0 .
\end{gathered}
$$

Multiplying by $\Psi\left(G_{0}\right)$ from the left the second column of the matrix in (16) and then adding to the first column, we get

$$
\begin{gathered}
\operatorname{det} L_{1}=\operatorname{det}\left(\begin{array}{cc}
I_{m}-\Phi\left(A_{0}^{-1} G_{0}\right) & -\Phi\left(A_{0}^{-1} A^{-1} G\right) \\
0_{m} & I_{m}-\Psi\left(A^{-1} G\right)
\end{array}\right) \\
=\operatorname{det}\left[I_{m}-\Phi\left(A_{0}^{-1} G_{0}\right)\right] \operatorname{det}\left[I_{m}-\Psi\left(A^{-1} G\right)\right]=\operatorname{det} L_{0} \operatorname{det} L \neq 0 .
\end{gathered}
$$

So we proved that the operator $B_{1}$ is correct if and only if (13) is fulfilled. From (13), by Theorem 2 , follows that the operators $B$ and $B_{0}$ are correct.

Let now $u \in D\left(A A_{0}\right)$ and $B_{1} u=B B_{0} u=f$. Then, by Theorem 2 (ii), since $B, B_{0}$ are correct operators, we obtain

$$
\begin{gathered}
B_{0} u=B^{-1} f=A^{-1} f+A^{-1} G L^{-1} \Psi\left(A^{-1} f\right), \\
u=B_{0}^{-1}\left(A^{-1} f+A^{-1} G L^{-1} \Psi\left(A^{-1} f\right)\right) .
\end{gathered}
$$

Denote $g=A^{-1} f+A^{-1} G L^{-1} \Psi\left(A^{-1} f\right)$. By using Theorem 2 (ii) again, with $A_{0}, G_{0}, \Phi, L_{0}, g$ in place of $A, G, \Psi, L, f$ respectively, we get

$$
\begin{gathered}
u=B_{0}^{-1} g=A_{0}^{-1} g+A_{0}^{-1} G_{0} L_{0}^{-1} \Phi\left(A_{0}^{-1} g\right)=A_{0}^{-1}\left(A^{-1} f+A^{-1} G L^{-1} \Psi\left(A^{-1} f\right)\right) \\
+A_{0}^{-1} G_{0} L_{0}^{-1} \Phi\left(A_{0}^{-1}\left(A^{-1} f+A^{-1} G L^{-1} \Psi\left(A^{-1} f\right)\right)\right)=A_{0}^{-1} A^{-1} f+A_{0}^{-1} A^{-1} G L^{-1} \Psi\left(A^{-1} f\right) \\
+A_{0}^{-1} G_{0} L_{0}^{-1}\left[\Phi\left(A_{0}^{-1} A^{-1} f\right)+\Phi\left(A_{0}^{-1} A^{-1} G\right) L^{-1} \Psi\left(A^{-1} f\right)\right],
\end{gathered}
$$

which implies (14). The theorem is proved.

The next theorem is useful for applications and is proved by using Theorem 3 . 
Theorem 4. Let the spaces $X, Z_{0}, Z$, the vectors $S, G, \Phi, \Psi$ be defined as in Theorem 3 and the operator $B_{1}: X \rightarrow X$ by

$$
B_{1} u=\mathcal{A} u-S \Phi(u)-G \Psi\left(A_{0} u\right)=f, \quad u \in D\left(B_{1}\right),
$$

where $A_{0}$ is a correct $m$-order differential operator with $D\left(A_{0}\right) \subset Z_{0}$ and $\mathcal{A}$ is a $n$-order differential operator, $m<n$. Then the next statements are fulfilled:

(i) If there exists an $n-m$ order differential bijective operator $A: X \rightarrow X$ such that

$$
\begin{gathered}
\mathcal{A}=A A_{0}, \quad D\left(B_{1}\right)=D\left(A A_{0}\right), \quad D(A) \subset Z \subseteq X, \\
\operatorname{det} L=\operatorname{det}\left[I_{m}-\Psi\left(A^{-1} G\right)\right] \neq 0,
\end{gathered}
$$

then the operator $B_{1}$ is factorized as $B_{1}=B B_{0}$, where $B_{0}, B$ are defined by (9), (10),

$$
G_{0}=A^{-1} S+A^{-1} G L^{-1} \Psi\left(A^{-1} S\right)
$$

the operator $A$ and vectors $G, \Psi$ are determined from (18) and (17), respectively, and the operator $A_{0}$ and a vector $\Phi$ from (17).

(ii) If in addition to (i) $A$ is correct, then the operator $B_{1}=B B_{0}$ is correct if and only if

$$
\operatorname{det} L_{0}=\operatorname{det}\left[I_{m}-\Phi\left(A_{0}^{-1} G_{0}\right)\right] \neq 0
$$

and the unique solution of (17), (18) is given by

$$
u=B_{0}^{-1} B^{-1} f=B_{0}^{-1} v=A_{0}^{-1} v+A_{0}^{-1} G_{0} L_{0}^{-1} \Phi\left(A_{0}^{-1} v\right),
$$

where

$$
v=A^{-1} f+A^{-1} G L^{-1} \Psi\left(A^{-1} f\right) .
$$

Proof. (i) Suppose that there exist the operators $A, B, B_{0}$, defined in (i). Acting by the operator $B$ on the vector $G_{0}$, defined by $(20)$, we get.

$$
\begin{gathered}
B G_{0}=A G_{0}-G \Psi\left(G_{0}\right) \\
=A\left(A^{-1} S+A^{-1} G L^{-1} \Psi\left(A^{-1} S\right)\right)-G \Psi\left(A^{-1} S+A^{-1} G L^{-1} \Psi\left(A^{-1} S\right)\right) \\
=S+G L^{-1} \Psi\left(A^{-1} S\right)-G \Psi\left(A^{-1} S\right)-G \Psi\left(A^{-1} G\right) L^{-1} \Psi\left(A^{-1} S\right) \\
=S+G\left[I_{m}-\Psi\left(A^{-1} G\right)\right] L^{-1} \Psi\left(A^{-1} S\right)-G \Psi\left(A^{-1} S\right)=S .
\end{gathered}
$$

So $B G_{0}=S$. From (17) for $\mathcal{A}=A A_{0}$ and $B G_{0}=S$ we get

$$
B_{1} u=A A_{0} u-B G_{0} \Phi(u)-G \Psi\left(A_{0} u\right)=f, \quad u \in D\left(A A_{0}\right) .
$$

Denote $y=A_{0} u$. Then from (24) for any $u \in D\left(A A_{0}\right)$ follows that

$$
B_{1} u=A y-G \Psi(y)-B G_{0} \Phi(u)=B y-B G_{0} \Phi(u)=B\left(A_{0} u-G_{0} \Phi(u)\right)=B B_{0} u .
$$

In Theorem 3 (i) we proved that $D\left(B B_{0}\right)=D\left(A A_{0}\right)=D\left(B_{1}\right)$. Consequently, $B_{1}$ is factorized in $B_{1}=B B_{0}$.

(ii) Let $A$ be a correct operator. Then by Theorem 2, since (19), (21), the operators $B, B_{0}$ are correct too. Remind that for $G_{0}$, defined by (20), we proved in (i) that $B G_{0}=S$. Then by Theorem 3 (i), (iii), we have the factorization $B_{1}=B B_{0}$ and $B_{1}$ is correct if and only if $\operatorname{det} L \neq 0$ and $\operatorname{det} L_{0} \neq 0$. But by assumption $\operatorname{det} L \neq 0$. Thus $B_{1}$ is correct if and only if (21) holds. Let $B B_{0} u=f$ for any $f \in X$. Then because of the operators $B, B_{0}$ are correct, we obtain

$$
B_{0} u=B^{-1} f=A^{-1} f+A^{-1} G L^{-1} \Psi\left(A^{-1} f\right) .
$$

From the above, denoting $v=A^{-1} f+A^{-1} G L^{-1} \Psi\left(A^{-1} f\right)$, follows that

$$
B_{0} u=v, \quad u=B_{0}^{-1} v=A_{0}^{-1} v+A_{0}^{-1} G_{0} L_{0}^{-1} \Phi\left(A_{0}^{-1} v\right),
$$

which give (23) and (22). So the theorem is proved.

Remark 5. Usually in applications $X$ is the space $C[a, b]$ or $L_{p}(a, b), p=1,2, \ldots$, and $Z_{0}, Z$ are the spaces $C^{k}[a, b]$ or $W_{p}^{k}(a, b), k=1, \ldots, n$, respectively. Problem (17) can be solved by factorization method if it is possible to determine from (17) the vectors $S, G, \Phi, \Psi$ and the operators $A_{0}, A$ such that

$$
\mathcal{A}=A A_{0}, \quad D\left(B_{1}\right)=D\left(A A_{0}\right), \quad D(A) \subset Z, \quad D\left(A_{0}\right) \subset Z_{0}, \quad \operatorname{det} L \neq 0, \quad \operatorname{det} L_{0} \neq 0 .
$$

If the above conditions are fulfilled, then a unique solution to (17) can be found by (22), (23), where $G_{0}$ is given by $(20)$. 


\section{Illustrative Examples}

To explain the implementation of the factorization method and to show its efficiency, we solve two example problems.

Example 1. Let us find the solution of the nonlocal boundary value problem

$$
\begin{gathered}
u^{\prime \prime}(t)-(t+1) \int_{0}^{1}(t-1) u(t) d t-t^{2} \int_{0}^{1} t^{3} u^{\prime}(t) d t=2-3 t, \quad 0<t<1 \\
u(0)+u(1)=0, \quad u^{\prime}(0)-4 u^{\prime}(1)=0 .
\end{gathered}
$$

The operator $B_{1}: C[0,1] \rightarrow C[0,1]$ corresponding to the problem is correct. The unique solution to problem (25) is given by the formula

$$
u(t)=-\frac{5\left(1204 t^{4}+402256 t^{3}-811850 t^{2}+549488 t-70549\right)}{4037236} .
$$

Proof. First we need to find the operators $A, A_{0}$ and check the condition $D\left(B_{1}\right)=D\left(A A_{0}\right)$. If we compare equation (25) with Problem (17), (18), it is natural to take $X=C[0,1], m=1, I_{m}=1$,

$$
\begin{gathered}
\mathcal{A} u=A A_{0} u=u^{\prime \prime}(t), \\
D\left(B_{1}\right)=\left\{u(t) \in C^{2}[0,1]: u(0)+u(1)=0, \quad u^{\prime}(0)-4 u^{\prime}(1)=0\right\}, \\
A_{0} u(t)=u^{\prime}(t), \quad D\left(A_{0}\right)=\left\{u(t) \in C^{1}[0,1]: u(0)=-u(1)\right\} \\
\Phi(u)=\int_{0}^{1}(t-1) u(t) d t, \quad \Psi\left(A_{0} u\right)=\int_{0}^{1} t^{3} u^{\prime}(t) d t
\end{gathered}
$$

$S=t+1, G=t^{2}$. Let us denote $A_{0} u(t)=u^{\prime}(t)=y(t)=y$. Then from (27) we have $y \in D(A)$, $A A_{0} u=\left(u^{\prime}(t)\right)^{\prime}=y^{\prime}(t)=A y(t), y(0)-4 y(1)=0$. So we proved that

$$
A y=y^{\prime}(t), \quad D(A)=\left\{y(t) \in C^{1}[0,1]: y(0)-4 y(1)=0\right\} .
$$

Further by definition we find

$$
\begin{gathered}
D\left(A A_{0}\right)=\left\{u(t) \in D\left(A_{0}\right): A_{0} u(t) \in D(A)\right\} \\
=\left\{u(t) \in C^{1}[0,1]: u(0)=-u(1), u^{\prime}(t) \in C^{1}[0,1], u^{\prime}(0)-4 u^{\prime}(1)=0\right\} \\
=\left\{u(t) \in C^{2}[0,1]: u(0)+u(1)=0, \quad u^{\prime}(0)-4 u^{\prime}(1)=0\right\}=D\left(B_{1}\right) .
\end{gathered}
$$

So $D\left(B_{1}\right)=D\left(A A_{0}\right)$. It is easy to verify that the operators $A, A_{0}$ are correct on $C[0,1]$ and that for every $f(t) \in C[0,1]$ the following formulae hold true

$$
\begin{aligned}
& A^{-1} f(t)=\int_{0}^{t} f(x) d x-\frac{4}{3} \int_{0}^{1} f(x) d x \\
& A_{0}^{-1} f(t)=\int_{0}^{t} f(x) d x-\frac{1}{2} \int_{0}^{1} f(x) d x .
\end{aligned}
$$

From (28) we have

$$
\Phi(f)=\int_{0}^{1}(x-1) f(x) d x, \quad \Psi(f)=\int_{0}^{1} x^{3} f(x) d x .
$$

Then $|\Phi(f)| \leq \frac{1}{2}|| f(x)\left\|_{C}, \quad|\Psi(f)| \leq \frac{1}{4}|| f(x)\right\|_{C}$, that is $\Phi, \Psi \in C^{*}[0,1]$ and $Z_{0}=Z=C[0,1]$. Using (29), (31) and (19), we obtain

$$
\begin{gathered}
A^{-1} G=\int_{0}^{t} x^{2} d x-\frac{4}{3} \int_{0}^{1} x^{2} d x=\frac{t^{3}}{3}-\frac{4}{9} \\
\Psi\left(A^{-1} G\right)=\int_{0}^{1} x^{3}\left(\frac{x^{3}}{3}-\frac{4}{9}\right) d x=-\frac{4}{63}, \\
\operatorname{det} L=\operatorname{det}\left[I_{m}-\Psi\left(A^{-1} G\right)\right]=1+4 / 63=67 / 63, \quad L^{-1}=63 / 67 .
\end{gathered}
$$


So (19) is fulfilled. Further using (20), (23), (29), (31) for $S=t+1, G=t^{2}$ and $f(t)=2-3 t$ we find

$$
\begin{gathered}
A^{-1} f=-\frac{3 t^{2}}{2}+2 t-\frac{2}{3}, \quad \Psi\left(A^{-1} f\right)=-\frac{1}{60}, \\
v=A^{-1} f+A^{-1} G L^{-1} \Psi\left(A^{-1} f\right)=-\frac{7 t^{3}+2010 t^{2}-2680 t+884}{1340}, \\
A^{-1} S=\int_{0}^{t}(x+1) d x-\frac{4}{3} \int_{0}^{1}(x+1) d x=\frac{t^{2}}{2}+t-2, \\
\Psi\left(A^{-1} S\right)=\int_{0}^{1} x^{3}\left(\frac{x^{2}}{2}+x-2\right) d x=-\frac{13}{63}, \\
G_{0}=A^{-1} S+A^{-1} G L^{-1} \Psi\left(A^{-1} S\right)=-\frac{273 t^{3}-2010 t^{2}-4020 t+7676}{4020} .
\end{gathered}
$$

Taking into account (30), (31), we obtain

$$
A_{0}^{-1} G_{0}=-\frac{546 t^{4}-5360 t^{3}-16080 t^{2}+61408 t-20257}{32160}, \quad \Phi\left(A_{0}^{-1} G_{0}\right)=-\frac{44509}{964800} .
$$

Since

$$
\operatorname{det} L_{0}=\operatorname{det}\left[I_{m}-\Phi\left(A_{0}^{-1} G_{0}\right)\right]=\frac{1009309}{964800} \neq 0, \quad \text { then } \quad L_{0}^{-1}=\frac{964800}{1009309},
$$

and by Theorem 4 (ii), Problem (25) is correct. By (30)-(32) we calculate

$$
A_{0}^{-1} v=-\frac{14 t^{4}+5360 t^{3}-10720 t^{2}+7072 t-863}{10720}, \quad \Phi\left(A_{0}^{-1} v\right)=\frac{1223}{107200} .
$$

Substituting these values into (22), i.e.,

$$
u=A_{0}^{-1} v+A_{0}^{-1} G_{0} L_{0}^{-1} \Phi\left(A_{0}^{-1} v\right),
$$

we obtain the unique solution to (25), which is given by (26).

Example 2. Let $\bar{\Pi}=\left\{(t, s) \in \mathbb{R}^{2}: 0 \leq t, s \leq 1\right\}, u=u(t, s), u_{t}^{\prime}, u_{t s}^{\prime \prime} \in C(\bar{\Pi})$. The operator $B_{1}: C(\bar{\Pi}) \rightarrow C(\bar{\Pi})$ corresponding to the problem:

$$
\begin{gathered}
u_{t s}^{\prime \prime}(t, s)-(2 t-s) \int_{0}^{1} \int_{0}^{1} u(t, s) d t d s-(t+s) \int_{0}^{1} \int_{0}^{1} t s u_{t}^{\prime}(t, s) d t d s \\
=-\frac{213 s+149 t-600}{220}, \\
u(0, s)=s \int_{0}^{1} \int_{0}^{1} t^{2} u(t, s) d t d s, \\
u_{t}^{\prime}(t, 0)=(2 t-1) \int_{0}^{1} \int_{0}^{1}(s+3) u_{t}^{\prime}(t, s) d t d s
\end{gathered}
$$

is correct. The unique solution to Problem (33) is given by the formula

$$
u(t, s)=\frac{6 s(25 t+1)+275 t(t-1)}{55} .
$$

Proof. First we need to find the operators $A, A_{0}$ and check the condition $D\left(B_{1}\right)=D\left(A A_{0}\right)$. If we compare (33) with Problem (17), (18), it is natural to take $X=C(\bar{\Pi}), m=1, I_{m}=1$,

$$
\begin{gathered}
A A_{0} x=u_{t s}^{\prime \prime}(t, s), \\
D\left(B_{1}\right)=\left\{u(t, s) \in C(\bar{\Pi}), u_{t}^{\prime}, u_{t s}^{\prime \prime} \in C(\bar{\Pi}), \quad u(0, s)=s \int_{0}^{1} \int_{0}^{1} t^{2} u(t, s) d t d s,\right.
\end{gathered}
$$




$$
\begin{gathered}
\left.u_{t}^{\prime}(t, 0)=(2 t-1) \int_{0}^{1} \int_{0}^{1}(s+3) u_{t}^{\prime}(t, s) d t d s\right\} \\
A_{0} u(t, s)=u_{t}^{\prime}(t, s), \\
D\left(A_{0}\right)=\left\{u(t, s) \in C(\bar{\Pi}): u_{t}^{\prime}(t, s) \in C(\bar{\Pi}), \quad u(0, s)=s \int_{0}^{1} \int_{0}^{1} t^{2} u(t, s) d t d s\right\}, \\
\Phi(u)=\int_{0}^{1} \int_{0}^{1} u(t, s) d t d s, \quad \Psi\left(A_{0} u\right)=\int_{0}^{1} \int_{0}^{1} t s u_{t}^{\prime}(t, s) d t d s,
\end{gathered}
$$

$S=2 t-s, G=t+s, f=-(213 s+149 t-600) / 220$. In $(37)$, denote $A_{0} u(t, s)=u_{t}^{\prime}(t, s)=y(t, s)=y$. Then from $(35),(36)$ we have $y \in D(A), A A_{0} u=\left(u_{t}^{\prime}(t, s)\right)_{s}^{\prime}=y_{s}^{\prime}(t, s)=A y(t, s)$ and $y(t, 0)=(2 t-1) \int_{0}^{1} \int_{0}^{1}(s+3) y(t, s) d t d s$. So we proved that

$$
A y=y_{s}^{\prime}(t, s), \quad D(A)=\left\{y(t, s) \in C(\bar{\Pi}): y_{s}^{\prime} \in C(\bar{\Pi}), y(t, 0)=(2 t-1) \int_{0}^{1} \int_{0}^{1}(s+3) y(t, s) d t d s\right\} .
$$

Then by definition

$$
\begin{gathered}
D\left(A A_{0}\right)=\left\{u(t, s) \in D\left(A_{0}\right): A_{0} u(t, s) \in D(A)\right\} \\
=\left\{u(t, s) \in C(\bar{\Pi}): u_{t}^{\prime} \in C(\bar{\Pi}), \quad u(0, s)=s \int_{0}^{1} \int_{0}^{1} t^{2} u(t, s) d t d s\right. \\
\left.u_{t}^{\prime}(t, 0)=(2 t-1) \int_{0}^{1} \int_{0}^{1}(s+3) u_{t}^{\prime}(t, s) d t d s, \quad u_{t s}^{\prime \prime}(t, s) \in C(\bar{\Pi})\right\} \\
=\left\{u(t, s) \in C(\bar{\Pi}), u_{t}^{\prime}, u_{t s}^{\prime \prime} \in C(\bar{\Pi}), \quad u(0, s)=s \int_{0}^{1} \int_{0}^{1} t^{2} u(t, s) d t d s,\right. \\
\left.u_{t}^{\prime}(t, 0)=(2 t-1) \int_{0}^{1} \int_{0}^{1}(s+3) u_{t}^{\prime}(t, s) d t d s\right\}=D\left(B_{1}\right) .
\end{gathered}
$$

Thus $D\left(B_{1}\right)=D\left(A A_{0}\right)$. It is easy to verify that the operators $A, A_{0}$ are correct on $C(\bar{\Pi})$ and for every $f(t, s) \in C(\bar{\Pi})$ hold true

$$
\begin{gathered}
A^{-1} f(t, s)=\int_{0}^{s} f(t, x) d x+(2 t-1) \int_{0}^{1} \int_{0}^{1} \int_{0}^{s}(s+3) f(t, x) d x d t d s \\
A_{0}^{-1} f(t, s)=\int_{0}^{t} f(z, s) d z+\frac{6 s}{5} \int_{0}^{1} \int_{0}^{1} \int_{0}^{t} t^{2} f(z, s) d z d t d s
\end{gathered}
$$

From (38) we get

$$
\Phi(f)=\int_{0}^{1} \int_{0}^{1} f(t, s) d t d s, \quad \Psi(f)=\int_{0}^{1} \int_{0}^{1} t s f(t, s) d t d s .
$$

Then $\Phi, \Psi \in C^{*}(\bar{\Pi})$ and $Z_{0}=Z=C(\bar{\Pi})$. Using (39), (41) and (19) we obtain

$$
A^{-1} G=\frac{s^{2}}{2}+s t+\frac{37(2 t-1)}{24}, \quad \Psi\left(A^{-1} G\right)=\frac{29}{96}, \quad L=1-\Psi\left(A^{-1} G\right)=67 / 96, \quad L^{-1}=96 / 67 .
$$

So (19) is fulfilled. Further, using (39), (41), (23), (20) for $S=2 t-s, G=t+s$ and $f(t)=-(213 s+149 t-$ $-600) / 220$ we find

$$
\begin{gathered}
A^{-1} f=-\frac{2556 s^{2}+24 s(149 t-600)-19927(2 t-1)}{5280}, \quad \Psi\left(A^{-1} f\right)=\frac{2675}{4224}, \\
v=A^{-1} f+A^{-1} G L^{-1} \Psi\left(A^{-1} f\right)=-\frac{336 s^{2}-6 s(424 t+5025)-57187(2 t-1)}{11055}, \\
A^{-1} S=-\frac{s^{2}}{2}+2 s t+\frac{29(2 t-1)}{24}, \quad \Psi\left(A^{-1} S\right)=\frac{25}{96},
\end{gathered}
$$




$$
G_{0}=A^{-1} S+A^{-1} G L^{-1} \Psi\left(A^{-1} S\right)=-\frac{42 s^{2}-318 s t-239(2 t-1)}{134} .
$$

Taking into account (40), (41) we obtain

$$
A_{0}^{-1} G_{0}=-\frac{2100 s^{2} t-3 s\left(2650 t^{2}+9\right)-11950 t(t-1)}{6700}, \quad \Phi\left(A_{0}^{-1} G_{0}\right)=-\frac{6019}{40200} .
$$

Since

$$
\operatorname{det} L_{0}=\operatorname{det}\left[I_{m}-\Phi\left(A_{0}^{-1} G_{0}\right)\right]=\frac{46219}{40200} \neq 0,
$$

then $L_{0}^{-1}=\frac{40200}{46219}$, and hence by Theorem 4 (ii), problem (33) is correct. By (40)-(42) we calculate

$$
\begin{gathered}
A_{0}^{-1} v=-\frac{8400 s^{2} t-6 s\left(5300 t^{2}+125625 t+5043\right)-1429675 t(t-1)}{276375}, \\
\Phi\left(A_{0}^{-1} v\right)=-\frac{92438}{829125} .
\end{gathered}
$$

Substituting the above values into (22), we obtain, by Theorem 4 (ii), the unique solution of (33)

$$
u=A_{0}^{-1} v+A_{0}^{-1} G_{0} L_{0}^{-1} \Phi\left(A_{0}^{-1} v\right)=\frac{6 s(25 t+1)+275 t(t-1)}{55},
$$

which is (34).

\section{References}

1 Adomian, G. (1994). Solving frontier problems of physics: The decomposition method. Kluwer Academic Publishers, Boston.

2 Barkovsky, L.M. (2002). Factorization of integro-differential equations of the acoustics of dispersive viscoelastic anisotropic media and the tensor integral operators of wake packet velocities. Acoustical Physics 48, 128-132.

3 Bloom, F. (1981). Ill posed Problems for Integrodifferential equations in mechanics and electromagnetic theory. SIAM. https://doi.org/10.1137/1.9781611970890.

4 Caruntu, D.I. (1996). Relied studies on factorization of the differential operator in the case of bending vibration of a class of beams with variable cross-section. Revue Roumaine des Sci. Tech. Serie de Micanique Appl., 41(5-6), 389-397.

5 Dong, S.H. (2007). Factorization method in quantum mechanics. Fund. Theories Phys. 150. Springer, Dordrecht.

6 Geiser, J. (2009). Decomposition methods for differential equations: theory and applications. CRC Press, Taylor and Francis Group.

7 Hirsa, A., \& Neftci, S.N. (2013). An introduction to the mathematics of financial derivatives. Academic Press, Cambridge. doi.org/10.1016/C2010-0-64929-7

8 Kelesoglu, O. (2014). The solution of fourth order boundary value problem arising out of the beam-column theory using adomian decomposition method. Mathematical Problems in Engineering, 2014 , ID 649471. https://doi.org/10.1155/2014/649471

9 Kil'chevski, N.A. (1959). Integro-differential and integral equations of equilibrium of thin elastic shells. PMM, 23(1), 124-133.

10 Medlock, J., \& Kot, M. (2003). Spreading disease: integro-differential equations old and new. Math. Biosci. 184, 201-222. https://doi.org/10.1016/S0025-5564(03)00041-5

11 Nyashin, Y., Lokhov, V., \& Ziegler, F. (2005). Decomposition method in linear elastic problems with eigenstrain. Z. Angew. Math. Mech., 85, 557-570.

12 Araghi, M., \& Behzadi, S. (2009). Solving nonlinear Volterra-Fredholm integro-differential equations using the modified Adomian decomposition method. Comput. Methods Appl. Math., 9(4), 321-331.

13 Babolian, E., Biazar, J, \& Vahidi, A.R. (2004). The decomposition method applied to systems of Fredholm integral equations of the second kind. Appl. Math. Comput., 148, 443-452. 
14 Baskonus, H.M., Bulut, H., \& Pandir, Y. (2014). The natural transform decomposition method for linear and nonlinear partial differential equations. Mathematics in Engineering, Science and Aerospace, 5(1), $111-126$.

15 Hamoud, A.A., \& Ghadle, K.P. (2017). The reliable modified of Laplace Adomian decomposition method to solve nonlinear interval Volterra-Fredholm integral equations. Korean J. Math., 25(3), 323-334.

16 Khachatryan, A.K., \& Khachatryan K.A. (2008). Factorization of a convolution-type integrodifferential equation on the positive half line. Ukrains'kyi Matematychnyi Zhurnal, 60(11), 1555-1567. http://umj.imath.kiev.ua/index.php/umj/article/view/3269

17 Al-Khaled, K., \& Allan, F. (2005). Decomposition method for solving nonlinear integro-differential equations. J. Appl. Math. Computing, 19(1-2), 415-425.

18 Mittal, R. \& Nigam, R. (2008). Solution of fractional integro-differential equations by Adomian decomposition method. Int. J. Appl. Math. Mech., 4(2), 87-94.

19 Moumouni, S., Soumanou, V.M.S., Massou, S., Essoun, A.L., \& Tchoffo, M. (2016). Generalization and resolution of the homogeneous reaction-diffusion equations by the method of factorization of ordinary differential operators. Advances in Differential Equations and Control Processes, 17(4), 265-283. http:// dx.doi.org/10.17654/DE017040265

20 Yang, C., Hou, J. (2013). Numerical solution of integro-differential equations of fractional order by Laplace decomposition method. Wseas Trans. Math., 12(12), 1173-1183.

21 Parasidis, I.N., Providas E., \& Tsekrekos, P.C. (2012). Factorization of linear operators and some eigenvalue problems of special operators. Vestn. Bashkir. Univ., 17(2), 830-839.

22 Parasidis, I.N. (2019). Extension and decomposition method for differential and integro-differential equations. Eurasian Mathematical Journal, 10(3), 48-67.

23 Providas, E. (2021). Operator factorization and solution of second-order nonlinear difference equations with variable coefficients and multipoint constraints. In T.M. Rassias, P.M. Pardalos (Eds.), Nonlinear Analysis and Global Optimization (pp. 427-443 ). Springer Optimization and Its Applications, vol. 167. Springer, Cham. https://doi.org/10.1007/978-3-030-61732-5

24 Providas, E. (2021). Factorization and solution of linear and nonlinear second order differential equations with variable coefficients and mixed conditions. In T.M. Rassias (Ed.), Nonlinear Analysis, Differential Equations and Applications. Springer Optimization and Its Applications, vol. 173. Springer, Cham (2021). https://doi.org/10.1007/978-3-030-72563-1

25 Parasidis, I.N., \& Tsekrekos, P.C. (2010) Some quadratic correct extensions of minimal operators in Banach space. Operators and Matrices, 4 (2), 225-243. dx.doi.org/10.7153/oam-04-11

26 Vassiliev, N.N., Parasidis, I.N., \& Providas, E. (2019). Exact solution method for Fredholm integrodifferential equations with multipoint and integral boundary conditions. Part 2. Decomposition-extension method for squared operators. Information and Control Systems, 2, 2-9.

https://doi.org/10.31799/1684-8853-2019-2-2-9

27 Parasidis, I.N., Providas, E., \& Zaoutsos, S. (2020). On the solution of boundary value problems for ordinary differential equations of order $\mathrm{n}$ and $2 \mathrm{n}$ with general boundary conditions. In N. Daras, T. Rassias (Eds.), Computational Mathematics and Variational Analysis (pp. 299-314). Springer Optimization and Its Applications, vol 159. Springer, Cham. https://doi.org/10.1007/978-3-030-44625-3

28 Parasidis, I.N., \& Providas, E. (2016). Extension operator method for the exact solution of integrodifferential equations. In P. Pardalos, T. Rassias (Eds). Contributions in Mathematics and Engineering (pp. 473-496). Springer, Cham. https://doi.org/10.1007/978-3-319-31317-7 
И.Н. Парасидис, Е. Провидас

Фессалия университеті, Лариса, Грещия

\title{
Банах кеңістігінде локальді емес шекаралық есептерді шешуге арналған факторизация әдісі
}

Мақала банах кеңістігінде абстрактілі операторлары бар

$$
B_{1} u=\mathcal{A} u-S \Phi(u)-G \Psi\left(A_{0} u\right)=f, \quad u \in D\left(B_{1}\right),
$$

түріндегі локалды емес шектік есептерді факторизациялау және шешуге арналған, мұндағы $\mathcal{A}, A_{0}$ сызықтық дерексіз операторлар, $S, G$ функция векторлары, $\Phi, \Phi$ сызықтық шектеулі функционалды векторлар және $u, f$ функциялар. $B_{1}$ операторы белгілі бір жағдайларда $B_{1}=B b_{0}$ кіші екі қарапайым оператордың көбейтіндісіне факторлануы мүмкін екендігі көрсетілген. Содан кейін $B_{1} u=f$ теңдеуінің шешімі мен жалғыз шешімі $B v=f$ және $b_{0} u=v$ теңдеулер шешімдерінің шешімділігі мен бірегейлігі шарттарынан оңай туындайды. Ұсынылған әмбебап әдіс басқа факторизация әдістерінен айтарлықтай ерекшеленеді, өйткені оған теңдеу мен шекаралық шарттардың факторизациясы кіреді және шешімді жабық түрде ұсынады. Бұл әдіс Фредгольмның қарапайым және жартылай интегродифференциалдық теңдеулерін шешуге арналған.

Kiлm сөздер: шекаралық есептер, жергілікті емес жағдайлар, факторизация, сызықтық операторлар, интегро-дифференциалдық теңдеулер, жабық түрдегі шешімдер.

\author{
И.Н. Парасидис, Е. Провидас \\ Университет Фессалии, Лариса, Греция
}

\section{Метод факторизации для решения нелокальных краевых задач в банаховом пространстве}

Статья посвящена факторизации и решению нелокальных краевых задач с операторами абстрактного вида

$$
B_{1} u=\mathcal{A} u-S \Phi(u)-G \Psi\left(A_{0} u\right)=f, \quad u \in D\left(B_{1}\right),
$$

в банаховом пространстве, где $\mathcal{A}, A_{0}$ - линейные абстрактные операторы; $S, G$ - векторы функций; $\Phi, \Psi$ - векторы линейных ограниченных функционалов; а $u, f$ - функции. Показано, что оператор $B_{1}$ при определенных условиях может быть факторизован в произведение двух более простых операторов меньшего порядка $B_{1}=B B_{0}$. Тогда разрешимость и единственное решение уравнения $B_{1} u=f$ легко следует из условий разрешимости и единственности решений уравнений $B v=f$ и $B_{0} u=v$. Предлагаемый универсальный метод существенно отличается от других методов факторизации, поскольку он включает факторизацию уравнения и граничных условий и предоставляет решение в замкнутой форме. Метод разработан для решения обыкновенных и частных интегро-дифференциальных уравнений Фредгольма.

Ключевые слова: краевые задачи, нелокальные условия, факторизация, линейные операторы, интегродифференциальные уравнения, решения в замкнутой форме. 
DOI $10.31489 / 2021 \mathrm{M} 3 / 87-95$

UDC 517.58

\author{
M.I. Qureshi, J. Majid*, A.H. Bhat \\ Jamia Millia Islamia (A Central University), New Delhi, India \\ (E-mail: miqureshi_delhi@yahoo.co.in, javidmajid375@gmail.com, aarifsaleem19@gmail.com)
}

\title{
Summation of some infinite series by the methods of Hypergeometric functions and partial fractions
}

In this article, we obtain the summations of some infinite series by partial fraction method and by using certain hypergeometric summation theorems of positive and negative unit arguments, Riemann Zeta functions, polygamma functions, lower case beta functions of one-variable and other associated functions. We also obtain some hypergeometric summation theorems for:

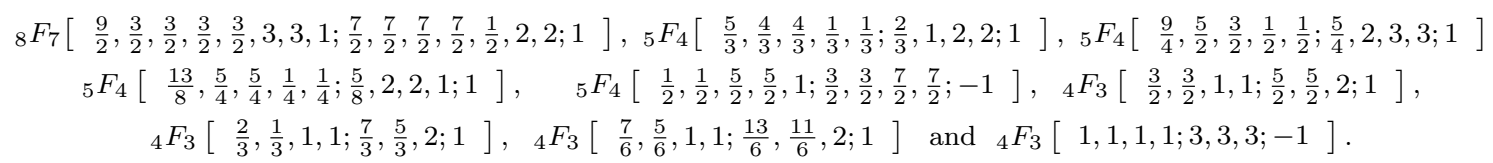

Keywords: Riemann Zeta functions, Polygamma functions, Dougall's theorem, Bernoulli polynomials, Catalan's constant.

\section{Introduction and preliminaries}

In this paper, we shall use the following standard notations:

$$
\mathbb{N}:=\{1,2,3, \cdots\} ; \quad \mathbb{N}_{0}:=\mathbb{N} \bigcup\{0\} ; \quad \mathbb{Z}_{0}^{-}:=\mathbb{Z}^{-} \bigcup\{0\}=\{0,-1,-2,-3, \cdots\} .
$$

The symbols $\mathbb{C}, \mathbb{R}, \mathbb{N}, \mathbb{Z}, \mathbb{R}^{+}$and $\mathbb{R}^{-}$denote the sets of complex numbers, real numbers, natural numbers, integers, positive and negative real numbers respectively.

The classical Pochhammer symbol $(\alpha)_{p}(\alpha, p \in \mathbb{C})$ is defined by ( [1; 22, Eq.(1), p.32, Q.N.(8) and Q.N.(9)], see also [2; 23, Eq.(22) and Eq.(23)]).

A natural generalization of the Gaussian hypergeometric series ${ }_{2} F_{1}[\alpha, \beta ; \gamma ; z]$ is accomplished by introducing any arbitrary number of numerator and denominator parameters [2; 42, Eq.(1)].

The Riemann Zeta function $\zeta(z)([3 ; 19,4 ; 1037])$ is defined as:

$$
\begin{gathered}
\zeta(z)=\sum_{k=1}^{\infty} \frac{1}{k^{z}} ; \mathfrak{R e}(z)>1 \\
\sum_{k=1}^{\infty} \frac{(-1)^{k}}{k^{z}}=\left(2^{1-z}-1\right) \zeta(z) ; \quad \mathfrak{R e}(z)>0 .
\end{gathered}
$$

The Catalan constant is defined as:

$$
\mathbf{G}=\sum_{k=0}^{\infty} \frac{(-1)^{k}}{(2 k+1)^{2}}={ }_{3} F_{2}\left[\begin{array}{rrr}
1, & \frac{1}{2}, & \frac{1}{2} ; \\
\frac{3}{2}, & \frac{3}{2} ; & -1
\end{array}\right]=0.9159655942 \ldots
$$

The logarithmic derivative of the Gamma function also known as psi function or Digamma function ([1; 10, Eq.(1)], [5; 24, Eq.(2)], [6; 12, Eq.(1)]), is defined as:

$$
\psi(z)=\frac{d}{d z} \ln \{\Gamma(z)\}=\frac{\Gamma^{\prime}(z)}{\Gamma(z)} ; \quad z \neq 0,-1,-2,-3, \ldots
$$

\footnotetext{
${ }^{*}$ Corresponding author.

E-mail: javidmajid375@gmail.com
} 


$$
\begin{gathered}
\psi(z)=-\gamma-\frac{1}{z}+\sum_{n=1}^{\infty} \frac{z}{n(z+n)} ; \quad z \neq 0,-1,-2,-3, \ldots, \\
\psi(z)=-\gamma-\sum_{n=0}^{\infty}\left\{\frac{1}{(z+n)}-\frac{1}{(n+1)}\right\} ; \quad z \neq 0,-1,-2,-3, \ldots,
\end{gathered}
$$

where $\gamma$ is Euler-Mascheroni constant and $\gamma \cong 0.577215664901532860606512 \ldots$.

$$
\begin{gathered}
\psi(1)=-\gamma, \quad \psi\left(\frac{2}{3}\right)=-\gamma+\frac{\pi \sqrt{3}}{6}-\frac{3}{2} \ln 3, \quad \psi\left(\frac{3}{2}\right)=2-2 \ln 2-\gamma, \\
\psi\left(\frac{5}{6}\right)=-\gamma+\frac{\pi \sqrt{3}}{2}-\frac{3}{2} \ln 3-2 \ln 2, \quad \psi\left(\frac{7}{6}\right)=6-\gamma-\frac{\pi \sqrt{3}}{2}-\frac{3}{2} \ln 3-2 \ln 2 . \\
\psi^{(1)}\left(\frac{3}{2}\right)=\frac{\pi^{2}}{2}-4, \quad \psi^{(1)}\left(\frac{5}{2}\right)=\frac{\pi^{2}}{2}-4.4, \\
\psi^{(2)}\left(\frac{3}{2}\right)=-\frac{14 \pi^{3}}{25.79436}+16, \quad \psi^{(2)}\left(\frac{5}{2}\right)=-\frac{14 \pi^{3}}{25.79436}+\frac{448}{27} .
\end{gathered}
$$

The polygamma function $\psi^{(n)}(z)$ ([5; 33, Eq.(52), Eq.(53), p.34, Eq.(58)], see also ([7; 260, Eq.(6.4.10), Eq.(6.4.4)], [8; 45, Eq.(9)], [3; 15]), is defined as:

$$
\begin{gathered}
\psi^{(n)}(z)=\frac{d^{n+1}}{d z^{n+1}} \ln (\Gamma(z))=\frac{d^{n}}{d z^{n}} \psi(z) ; \quad n \in \mathbb{N}_{0}, z \neq 0,-1,-2, \ldots \\
\psi^{(n)}(z)=(-1)^{n+1} n ! \sum_{k=0}^{\infty} \frac{1}{(z+k)^{n+1}} ; \quad n \in \mathbb{N}, z \neq 0,-1,-2, \ldots
\end{gathered}
$$

Lower case beta function of one variable:

$$
\begin{gathered}
\beta(z)=\frac{1}{2}\left[\psi\left(\frac{z+1}{2}\right)-\psi\left(\frac{z}{2}\right)\right]=\frac{G(z)}{2}, z \neq 0,-1,-2,-3, \ldots \\
\beta(z)=\sum_{k=0}^{\infty} \frac{(-1)^{k}}{(z+k)}=\frac{1}{z}{ }_{2} F_{1}\left[\begin{array}{cc}
1, & z ; \\
1+z ; & -1
\end{array}\right], \quad z \neq 0,-1,-2,-3, \ldots \\
\beta^{(n)}(z)=\frac{d^{n}}{d z^{n}} \beta(z)=(-1)^{n} n ! \sum_{k=0}^{\infty} \frac{(-1)^{k}}{(z+k)^{n+1}} ; \quad-z \in \mathbb{N}_{0} . \\
\beta(1)=\ell n 2, \beta^{(1)}(1)=-\frac{\pi^{2}}{12}, \quad \beta(2)=1-\ell n 2, \beta^{(1)}(2)=\frac{\pi^{2}}{12}-1, \\
\beta\left(\frac{1}{2}\right)=\frac{\pi}{2}, \beta^{(1)}\left(\frac{1}{2}\right)=-4 \mathbf{G}, \quad \beta\left(\frac{3}{2}\right)=\frac{4-\pi}{2}, \beta^{(1)}\left(\frac{3}{2}\right)=4 \mathbf{G}-4, \\
\beta\left(\frac{5}{2}\right)=\frac{\pi}{2}-\frac{4}{3}, \beta^{(1)}\left(\frac{5}{2}\right)=-4 \mathbf{G}+\frac{32}{9}, \quad \beta^{(2)}(1)=\frac{3 \pi^{3}}{51.58872}, \quad \beta^{(2)}(2)=2-\frac{3 \pi^{3}}{51.58872} .
\end{gathered}
$$

Some hypergeometric summation theorems in terms of Digamma $\psi(b)$, trigamma $\psi^{(1)}(b)$, tetragamma $\psi^{(2)}(b)$ functions and derivatives of lower case beta function of one-variable are given below ... [9; 489, Entry (7.3.6.(9))]

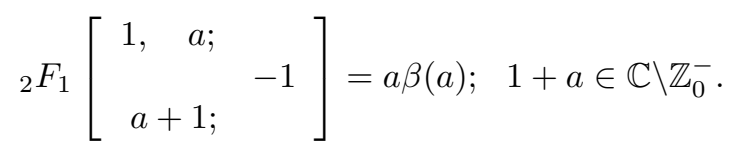

See ref. [9; 536, Entry (7.4.4.(33))]

$$
{ }_{3} F_{2}\left[\begin{array}{rrr}
1, & a, b ; \\
1+a, & 1+b ; & 1
\end{array}\right]=\frac{a b}{(b-a)}[\psi(b)-\psi(a)],
$$

where $1+a, 1+b \in \mathbb{C} \backslash \mathbb{Z}_{0}^{-}$and $b \neq a$. 
See ref. [9; 536, Entry (7.4.4.(34))]

$$
{ }_{3} F_{2}\left[\begin{array}{ccc}
1, & b, & b ; \\
b+1, & b+1 ; & 1
\end{array}\right]=b^{2} \psi^{(1)}(b)
$$

where $1+b \in \mathbb{C} \backslash \mathbb{Z}_{0}^{-}$and $b=a$.

See ref. [9; 546, Entry (7.4.5.(5))]

$$
{ }_{3} F_{2}\left[\begin{array}{ccc}
1, & a, & a ; \\
a+1, & a+1 ; & -1
\end{array}\right]=-a^{2} \beta^{(1)}(a),
$$

where $1+a \in \mathbb{C} \backslash \mathbb{Z}_{0}^{-}$and $b=a$.

See ref. [9; 554, Entry (7.5.3.(3))]

$$
{ }_{4} F_{3}\left[\begin{array}{cccc}
1, & a, & b, & c ; \\
1+a, 1+b, 1+c ; & 1
\end{array}\right]=-a b c\left[\frac{\psi(a)}{(b-a)(c-a)}+\frac{\psi(b)}{(a-b)(c-b)}+\frac{\psi(c)}{(a-c)(b-c)}\right],
$$

where $1+a, 1+b, 1+c \in \mathbb{C} \backslash \mathbb{Z}_{0}^{-}$and $a \neq b, b \neq c, a \neq c$.

See ref. [9; 554, Entry (7.5.3.(5))]

$$
{ }_{4} F_{3}\left[\begin{array}{cccc}
1, & b, & b, & b ; \\
b+1, & b+1, & b+1 ; & 1
\end{array}\right]=\frac{-b^{3}}{2} \psi^{(2)}(b),
$$

where $1+b \in \mathbb{C} \backslash \mathbb{Z}_{0}^{-}$and $a=b=c$.

See ref. [9; 561, Entry (7.5.4.(5))]

$$
{ }_{4} F_{3}\left[\begin{array}{ccc}
1, & a, \quad a, \quad a ; \\
a+1, & a+1, & a+1 ;
\end{array}\right]=\frac{a^{3}}{2} \beta^{(2)}(a),
$$

where $1+a \in \mathbb{C} \backslash \mathbb{Z}_{0}^{-}$and $a=b=c$.

Gauss' classical summation theorem [1; 49, Th.(18)] in terms of Gamma function is given by:

$$
{ }_{2} F_{1}\left[\begin{array}{ccc}
\alpha, & \beta ; & \\
& \gamma ; & 1
\end{array}\right]=\frac{\Gamma(\gamma) \Gamma(\gamma-\alpha-\beta)}{\Gamma(\gamma-\alpha) \Gamma(\gamma-\beta)},
$$

where $\mathfrak{R e}(\gamma-\alpha-\beta)>0$ and $\gamma \in \mathbb{C} \backslash \mathbb{Z}_{0}^{-}$.

Dougall's theorem ([10; 71, Eq.(2.2.10), p.147, Entry(3.5.2)],[11],[9; 564, Entry(7.6.2(3))], [12; 56, Eq.(2.3.4.5), p.244, Entry(III.12)]), see also [13; 27, Eq.(4.4(1))] in terms of Gamma function is given as:

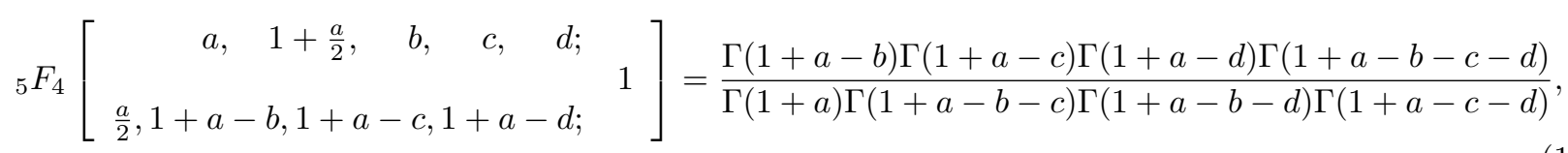

provided $\mathfrak{R e}(a-b-c-d)>-1$ and $\frac{a}{2}, 1+a-b, 1+a-c, 1+a-d \in \mathbb{C} \backslash \mathbb{Z}_{0}^{-}$.

The present article is organized as follows. In section 2, we have shown that the difference of two divergent series may be convergent. In section 3, we have obtained the summation of some infinite series whose general terms are rational functions of $n$, by using some summation theorems of positive and negative unit arguments and section 4 is related to the hypergeometrical representations of the involved infinite series. 


\section{The difference of two divergent series}

Consider the two positive terms infinite series $\sum_{n=0}^{\infty} \frac{1}{(3+2 n)}$ and $\sum_{n=0}^{\infty} \frac{1}{(5+2 n)}$, which are divergent in nature by using the comparison test.

Taking the difference of the above two series, we get

$$
\sum_{n=0}^{\infty} \frac{1}{(3+2 n)}-\sum_{n=0}^{\infty} \frac{1}{(5+2 n)}=\sum_{n=0}^{\infty} \frac{2}{(3+2 n)(5+2 n)} .
$$

The right hand side of equation (15) is convergent by using the Raabe's higher ratio test. In terms of hypergeometric function, the equation (15) can be written as

$$
\begin{gathered}
\frac{1}{3} \sum_{n=0}^{\infty} \frac{\left(\frac{3}{2}\right)_{n}}{\left(\frac{5}{2}\right)_{n}}-\frac{1}{5} \sum_{n=0}^{\infty} \frac{\left(\frac{5}{2}\right)_{n}}{\left(\frac{7}{2}\right)_{n}}=\frac{2}{15} \sum_{n=0}^{\infty} \frac{\left(\frac{3}{2}\right)_{n}}{\left(\frac{7}{2}\right)_{n}} \\
\frac{1}{3}{ }_{2} F_{1}\left[\begin{array}{ccc}
\frac{3}{2}, & 1 ; & \\
& & 1 \\
\frac{5}{2} ; &
\end{array}\right]-\frac{1}{5}{ }_{2} F_{1}\left[\begin{array}{rrr}
\frac{5}{2}, & 1 ; & \\
\frac{7}{2} ; & 1
\end{array}\right]=\frac{2}{15}{ }_{2} F_{1}\left[\begin{array}{rrr}
\frac{3}{2}, & 1 ; & \\
& \frac{7}{2} ; & 1
\end{array}\right] .
\end{gathered}
$$

Since both the Gauss' series having the positive unit argument on left hand side of equation (16) are divergent. On using Gauss' classical summation theorem (13) on right hand side of equation (16), we get

$$
\begin{aligned}
& \frac{1}{3}{ }_{2} F_{1}\left[\begin{array}{ccc}
\frac{3}{2}, & 1 ; & \\
& \frac{5}{2} ; & 1
\end{array}\right]-\frac{1}{5}{ }_{2} F_{1}\left[\begin{array}{ccc}
\frac{5}{2}, & 1 ; & \\
& \frac{7}{2} ; & 1
\end{array}\right]=\frac{2}{15} \frac{\Gamma\left(\frac{7}{2}\right) \Gamma\left(\frac{7}{2}-\frac{3}{2}-1\right)}{\Gamma\left(\frac{7}{2}-\frac{3}{2}\right) \Gamma\left(\frac{7}{2}-1\right)}, \\
& \frac{1}{3}{ }_{2} F_{1}\left[\begin{array}{rrr}
\frac{3}{2}, & 1 ; & \\
& \frac{5}{2} ; & 1
\end{array}\right]-\frac{1}{5}{ }_{2} F_{1}\left[\begin{array}{rrr}
\frac{5}{2}, & 1 ; & \\
& \frac{7}{2} ; & 1
\end{array}\right]=\frac{1}{3} \text {, }
\end{aligned}
$$

which is convergent.

Multiplying both sides of equation (17) by $\frac{3}{16}$, for application point of view in next section, we get the difference of two divergent Gauss' series having the positive unit argument may be convergent

$$
\frac{1}{16}{ }_{2} F_{1}\left[\begin{array}{ccc}
\frac{3}{2}, & 1 ; & \\
& \frac{5}{2} ; & 1
\end{array}\right]-\frac{3}{80}{ }_{2} F_{1}\left[\begin{array}{ccc}
\frac{5}{2}, & 1 ; & \\
& \frac{7}{2} ; & 1
\end{array}\right]=\frac{1}{16} .
$$

\section{Summation of some infinite series}

The following summation formulas of some infinite series are derived:

$$
\begin{aligned}
& \sum_{n=0}^{\infty} \frac{\left(4 n^{4}+32 n^{3}+87 n^{2}+92 n+28\right)}{\left(64 n^{6}+768 n^{5}+3792 n^{4}+9856 n^{3}+14220 n^{2}+10800 n+3375\right)}=\frac{5}{27}-\frac{\pi^{2}}{64} \\
& \sum_{n=0}^{\infty} \frac{\left(27 n^{3}+36 n^{2}+15 n+2\right)\left\{\left(\frac{1}{3}\right)_{n}\right\}^{4}}{(n !)^{4}(1+n)^{2}}=\frac{27}{4\left[\Gamma\left(\frac{2}{3}\right)\right]^{3}} . \\
& \sum_{n=0}^{\infty} \frac{\left(32 n^{4}+120 n^{3}+156 n^{2}+82 n+15\right)\left\{\left(\frac{1}{2}\right)_{n}\right\}^{4}}{(n !)^{4}\left(n^{5}+7 n^{4}+19 n^{3}+25 n^{2}+16 n+4\right)}=\frac{128}{3 \pi^{2}} \\
& \sum_{n=0}^{\infty} \frac{\left(128 n^{3}+144 n^{2}+48 n+5\right)\left\{\left(\frac{1}{4}\right)_{n}\right\}^{4}}{(n !)^{4}\left(n^{2}+2 n+1\right)}=\frac{32 \sqrt{2}}{3 \sqrt{\pi}\left[\Gamma\left(\frac{3}{4}\right)\right]^{2}} . \\
& \sum_{n=0}^{\infty} \frac{(-1)^{n}}{\left(16 n^{4}+96 n^{3}+184 n^{2}+120 n+25\right)}=\frac{\mathbf{G}}{8}-\frac{11}{144} .
\end{aligned}
$$




$$
\begin{aligned}
& \sum_{n=0}^{\infty} \frac{1}{\left(4 n^{3}+16 n^{2}+21 n+9\right)}=4-2 \ell n 2-\frac{\pi^{2}}{4} . \\
& \sum_{n=0}^{\infty} \frac{1}{\left(81 n^{4}+270 n^{3}+315 n^{2}+150 n+24\right)}=\frac{1}{6}+\frac{\pi}{12 \sqrt{3}}-\frac{1}{4} \ln 3 . \\
& \sum_{n=0}^{\infty} \frac{1}{\left(36 n^{3}+108 n^{2}+107 n+35\right)}=\ln 12+\ln \sqrt{3}-3 . \\
& \sum_{n=0}^{\infty} \frac{(-1)^{n+1}}{\left(n^{6}+9 n^{5}+33 n^{4}+63 n^{3}+66 n^{2}+36 n+8\right)}=10-12 \ln 2-\frac{3}{2} \zeta(3) .
\end{aligned}
$$

Proof of the result (19):

On factorizing the general term of equation (19) and making use of partial fractions, we have

$$
\begin{gathered}
\frac{\left(4 n^{4}+32 n^{3}+87 n^{2}+92 n+28\right)}{\left(64 n^{6}+768 n^{5}+3792 n^{4}+9856 n^{3}+14220 n^{2}+10800 n+3375\right)}= \\
=\frac{\frac{3}{16}}{(3+2 n)}+\frac{\frac{-1}{16}}{(3+2 n)^{2}}+\frac{\frac{-1}{4}}{(3+2 n)^{3}}+\frac{\frac{-3}{16}}{(5+2 n)}+\frac{\frac{-1}{16}}{(5+2 n)^{2}}+\frac{\frac{1}{4}}{(5+2 n)^{3}} .
\end{gathered}
$$

Now taking summation on both sides of equation (28) and $n$ varying from 0 to $\infty$, we get

$$
\begin{gathered}
\sum_{n=0}^{\infty} \frac{\left(4 n^{4}+32 n^{3}+87 n^{2}+92 n+28\right)}{\left(64 n^{6}+768 n^{5}+3792 n^{4}+9856 n^{3}+14220 n^{2}+10800 n+3375\right)}= \\
=\sum_{n=0}^{\infty} \frac{\frac{3}{16}}{(3+2 n)}++\frac{\frac{-1}{16}}{(3+2 n)^{2}}+\frac{\frac{-1}{4}}{(3+2 n)^{3}}+\frac{\frac{-3}{16}}{(5+2 n)}+\frac{\frac{-1}{16}}{(5+2 n)^{2}}+\frac{\frac{1}{4}}{(5+2 n)^{3}}= \\
=\frac{1}{16} \sum_{n=0}^{\infty} \frac{\left(\frac{3}{2}\right)_{n}}{\left(\frac{5}{2}\right)_{n}}-\frac{1}{144} \sum_{n=0}^{\infty} \frac{\left(\frac{3}{2}\right)_{n}\left(\frac{3}{2}\right)_{n}}{\left(\frac{5}{2}\right)_{n}\left(\frac{5}{2}\right)_{n}}-\frac{1}{108} \sum_{n=0}^{\infty} \frac{\left(\frac{3}{2}\right)_{n}\left(\frac{3}{2}\right)_{n}\left(\frac{3}{2}\right)_{n}}{\left(\frac{5}{2}\right)_{n}\left(\frac{5}{2}\right)_{n}\left(\frac{5}{2}\right)_{n}} \\
-\frac{3}{80} \sum_{n=0}^{\infty} \frac{\left(\frac{5}{2}\right)_{n}}{\left(\frac{7}{2}\right)_{n}}-\frac{1}{400} \sum_{n=0}^{\infty} \frac{\left(\frac{5}{2}\right)_{n}\left(\frac{5}{2}\right)_{n}}{\left(\frac{7}{2}\right)_{n}\left(\frac{7}{2}\right)_{n}}+\frac{1}{500} \sum_{n=0}^{\infty} \frac{\left(\frac{5}{2}\right)_{n}\left(\frac{5}{2}\right)_{n}\left(\frac{5}{2}\right)_{n}}{\left(\frac{7}{2}\right)_{n}\left(\frac{7}{2}\right)_{n}} .
\end{gathered}
$$

Using the definition of generalized hypergeometric function, we get

$$
\begin{aligned}
& \sum_{n=0}^{\infty} \frac{\left(4 n^{4}+32 n^{3}+87 n^{2}+92 n+28\right)}{\left(64 n^{6}+768 n^{5}+3792 n^{4}+9856 n^{3}+14220 n^{2}+10800 n+3375\right)}= \\
& =\frac{1}{16}{ }_{2} F_{1}\left[\begin{array}{cc}
\frac{3}{2}, 1 ; & \\
\frac{5}{2} ; & 1
\end{array}\right]-\frac{1}{144}{ }_{3} F_{2}\left[\begin{array}{c}
\frac{3}{2}, \frac{3}{2}, 1 ; \\
\frac{5}{2}, \frac{5}{2} ;
\end{array}\right]-\frac{1}{108}{ }_{4} F_{3}\left[\begin{array}{c}
\frac{3}{2}, \frac{3}{2}, \frac{3}{2}, 1 ; \\
\frac{5}{2}, \frac{5}{2}, \frac{5}{2} ;
\end{array}\right]- \\
& -\frac{3}{80}{ }_{2} F_{1}\left[\begin{array}{cc}
\frac{5}{2}, 1 ; & \\
\frac{7}{2} ; & 1
\end{array}\right]-\frac{1}{400}{ }_{3} F_{2}\left[\begin{array}{cc}
\frac{5}{2}, \frac{5}{2}, 1 ; & \\
\frac{7}{2}, \frac{7}{2} ; & 1
\end{array}\right]+\frac{1}{500}{ }_{4} F_{3}\left[\begin{array}{ccc}
\frac{5}{2}, \frac{5}{2}, \frac{5}{2}, 1 ; & 1 \\
\frac{7}{2}, \frac{7}{2}, \frac{7}{2} ; & 1
\end{array}\right] \text {. }
\end{aligned}
$$

Using summation theorems (8), (11) and the result (18), we get

$$
\begin{gathered}
\sum_{n=0}^{\infty} \frac{\left(4 n^{4}+32 n^{3}+87 n^{2}+92 n+28\right)}{\left(64 n^{6}+768 n^{5}+3792 n^{4}+9856 n^{3}+14220 n^{2}+10800 n+3375\right)}= \\
=\frac{1}{16}-\frac{1}{64} \psi^{(1)}\left(\frac{3}{2}\right)-\frac{1}{64} \psi^{(1)}\left(\frac{5}{2}\right)+\frac{1}{64} \psi^{(2)}\left(\frac{3}{2}\right)-\frac{1}{64} \psi^{(2)}\left(\frac{5}{2}\right)= \\
=\frac{1}{16}-\frac{1}{64}\left(\frac{\pi^{2}}{2}-4\right)-\frac{1}{64}\left(\frac{\pi^{2}}{2}-\frac{40}{9}\right)+\frac{1}{64}\left(\frac{-14 \pi^{3}}{25.79436}+16\right)-\frac{1}{64}\left(\frac{-14 \pi^{3}}{25.79436}+\frac{448}{27}\right) .
\end{gathered}
$$


On simplifying further, we arrive at the result (19).

Proof of the results (20) to (22):

The proof of the results (20) and (22) can be obtained in an analogous manner by following the same steps as in the proof of the result (19) and making use of the summation theorem (14).

Proof of the result (23):

The proof of the result (23) can be obtained by following the same procedure as in the proof of the result (19) and making use of the summation theorems (6), (9) and using the equations (4) and (5). So we omit the details here.

Proof of the result (24):

On factorizing the general term of equation (24) and making use of partial fractions, we have

$$
\frac{1}{\left(4 n^{3}+16 n^{2}+21 n+9\right)}=\frac{1}{(1+n)}+\frac{-2}{(3+2 n)}+\frac{-2}{(3+2 n)^{2}} .
$$

Now taking summation on both sides of equation (29) and $n$ varying from 0 to $\infty$, we get

$$
\begin{aligned}
& \sum_{n=0}^{\infty} \frac{1}{\left(4 n^{3}+16 n^{2}+21 n+9\right)}=\sum_{n=0}^{\infty}\left\{\frac{1}{(1+n)}+\frac{-2}{(3+2 n)}\right\}-2 \sum_{n=0}^{\infty} \frac{1}{(3+2 n)^{2}}= \\
& =\sum_{n=0}^{\infty} \frac{1}{(1+n)(3+2 n)}-2 \sum_{n=0}^{\infty} \frac{1}{(3+2 n)^{2}}= \\
& =\frac{1}{3} \sum_{n=0}^{\infty} \frac{(1)_{n}\left(\frac{3}{2}\right)_{n}}{(2)_{n}\left(\frac{5}{2}\right)_{n}}-\frac{2}{9} \sum_{n=0}^{\infty} \frac{\left(\frac{3}{2}\right)_{n}\left(\frac{3}{2}\right)_{n}}{\left(\frac{5}{2}\right)_{n}\left(\frac{5}{2}\right)_{n}}
\end{aligned}
$$

Using the definition of generalized hypergeometric function, we get

$$
\sum_{n=0}^{\infty} \frac{1}{\left(4 n^{3}+16 n^{2}+21 n+9\right)}=\frac{1}{3}{ }_{3} F_{2}\left[\begin{array}{crr}
\frac{3}{2}, 1,1 ; & 1 \\
\frac{5}{2}, 2 ; & 1
\end{array}\right]-\frac{2}{9}{ }_{3} F_{2}\left[\begin{array}{ccc}
\frac{3}{2}, \frac{3}{2}, & 1 ; & \\
\frac{5}{2}, & \frac{5}{2} ; & 1
\end{array}\right] .
$$

Using summation theorems (7) and (8), we get

$$
\sum_{n=0}^{\infty} \frac{1}{\left(4 n^{3}+16 n^{2}+21 n+9\right)}=\psi\left(\frac{3}{2}\right)-\psi(1)-\frac{1}{2} \psi^{(1)}\left(\frac{3}{2}\right)
$$

On simplifying further, we arrive at the result (24).

Proof of the result (25):

The proof of the result (25) can be obtained in an analogous manner by following the same steps as in the proof of the result (19) and (24) and making use of Gauss' classical summation theorem (13), the summation theorem (7) and using the equation (1). So, we omit the details here.

Proof of the result (26):

The proof of the result (26) can be obtained by following the same procedure as in the proof of the result (19) and (24) and making use of the summation theorem (10) and using the equations (1) and (2). So, we omit the details here.

Proof of the result (27):

Similarly for the proof of the result (27), we make use of the summation theorems (6), (9), (12) and the equations (3) and (5). So, we omit the details here.

\section{Representation of infinite series (19) to (27) in Hypergeometric forms}

The following hypergeometric representation formulas are derived:

$$
{ }_{8} F_{7}\left[\begin{array}{c}
\frac{9}{2}, \frac{3}{2}, \frac{3}{2}, \frac{3}{2}, \frac{3}{2}, 3,3,1 ; \\
\frac{7}{2}, \frac{7}{2}, \frac{7}{2}, \frac{7}{2}, \frac{1}{2}, 2,2 ;
\end{array}\right]=\frac{625}{28}-\frac{3375 \pi^{2}}{1792} .
$$




$$
\begin{aligned}
& { }_{5} F_{4}\left[\begin{array}{cccc}
\frac{5}{3}, \frac{4}{3}, \frac{4}{3}, \frac{1}{3}, \frac{1}{3} ; & 1 \\
\frac{2}{3}, 1,2,2 ; & 1
\end{array}\right]=\frac{27}{8\left[\Gamma\left(\frac{2}{3}\right)\right]^{3}} . \\
& { }_{5} F_{4}\left[\begin{array}{c}
\frac{9}{4}, \frac{5}{2}, \frac{3}{2}, \frac{1}{2}, \frac{1}{2} ; \\
\frac{5}{4}, 2,3,3 ;
\end{array}\right]=\frac{512}{45 \pi^{2}} \text {. } \\
& { }_{5} F_{4}\left[\begin{array}{r}
\frac{13}{8}, \frac{5}{4}, \frac{5}{4}, \frac{1}{4}, \frac{1}{4} ; \\
2,2,1, \frac{5}{8} ;
\end{array}\right]=\frac{32 \sqrt{2}}{15 \sqrt{\pi}\left[\Gamma\left(\frac{3}{4}\right)\right]^{2}} . \\
& { }_{5} F_{4}\left[\begin{array}{rrr}
1, \frac{1}{2}, & \frac{1}{2}, \frac{5}{2}, \frac{5}{2} ; & \\
\frac{3}{2}, & \frac{3}{2}, \frac{7}{2}, \frac{7}{2} ; & -1
\end{array}\right]=\frac{25 \mathbf{G}}{8}-\frac{275}{144} \text {. } \\
& { }_{4} F_{3}\left[\begin{array}{c}
\frac{3}{2}, \frac{3}{2}, 1,1 ; \\
\frac{5}{2}, \frac{5}{2}, 2 ;
\end{array}\right]=36-18 \ln 2-\frac{9 \pi^{2}}{4} . \\
& { }_{4} F_{3}\left[\begin{array}{c}
\frac{2}{3}, \frac{1}{3}, 1,1 ; \\
\frac{7}{3}, \frac{5}{3}, 2 ;
\end{array}\right]=4-6 \ln 3+\frac{2 \pi}{\sqrt{3}} . \\
& { }_{4} F_{3}\left[\begin{array}{c}
\frac{7}{6}, \frac{5}{6}, 1,1 ; \\
\frac{13}{6}, \frac{11}{6}, 2 ;
\end{array}\right]=35 \ln 12+35 \ln \sqrt{3}-105 \text {. } \\
& { }_{4} F_{3}\left[\begin{array}{rr}
1,1,1,1 ; & \\
3,3,3 ; & -1
\end{array}\right]=96 \ln 2-80+12 \zeta(3) .
\end{aligned}
$$

Proof of the result (30):

$$
\begin{gathered}
\sum_{n=0}^{\infty} \frac{\left(4 n^{4}+32 n^{3}+87 n^{2}+92 n+28\right)}{\left(64 n^{6}+768 n^{5}+3792 n^{4}+9856 n^{3}+14220 n^{2}+10800 n+3375\right)}= \\
=\sum_{n=0}^{\infty} \frac{(7+2 n)(1+2 n)(2+n)^{2}}{(3+2 n)^{3}(5+2 n)^{3}}=\frac{28}{3375} \sum_{n=0}^{\infty} \frac{\left(\frac{9}{2}\right)_{n}\left(\frac{3}{2}\right)_{n}\left(\frac{3}{2}\right)_{n}\left(\frac{3}{2}\right)_{n}\left(\frac{3}{2}\right)_{n}(3)_{n}(3)_{n}\left(\frac{1}{2}\right)_{n}\left(\frac{7}{2}\right)_{n}\left(\frac{7}{2}\right)_{n}\left(\frac{7}{2}\right)_{n}(2)_{n}(2)_{n}}{\left(\frac{7}{2}\right)}
\end{gathered}
$$

Using the definition of generalized hypergeometric function, we get

$$
\begin{aligned}
& \sum_{n=0}^{\infty} \frac{\left(4 n^{4}+32 n^{3}+87 n^{2}+92 n+28\right)}{\left(64 n^{6}+768 n^{5}+3792 n^{4}+9856 n^{3}+14220 n^{2}+10800 n+3375\right)}= \\
& =\frac{28}{3375}{ }_{8} F_{7}\left[\begin{array}{cc}
\frac{9}{2}, \frac{3}{2}, \frac{3}{2}, \frac{3}{2}, \frac{3}{2}, 3,3,1 ; & \\
\frac{7}{2}, \frac{7}{2}, \frac{7}{2}, \frac{7}{2}, \frac{1}{2}, 2,2 ; & 1
\end{array}\right] .
\end{aligned}
$$

Using equation (19) in equation (39), we arrive at the result (30).

Proof of the results (31) to (38):

The proof of the results (31) to (38) can be obtained in an analogous manner by following the same steps as in the proof of the above result (30). So we omit the details here.

\section{Conclusion}

In this paper, we have obtained the summation of some infinite series by using some summation theorems of positive and negative unit arguments, Riemann Zeta functions, polygamma functions, lower case beta functions of one-variable and other associated functions. We have also obtained some new hypergeometric summation theorems, which are not found in the literature. We conclude this paper with the remark that the summation of various other infinite series can be derived in an analogous manner. Moreover, the results deduced above are expected to lead to some potential applications in several fields of Applied Mathematics, Statistics and Engineering Sciences. 


\title{
Acknowledgments
}

The authors are very thankful to the anonymous referees for their valuable suggestions to improve the paper in its present form.

\section{References}

1 Rainville, E.D. (1971). Special Functions. Bronx, New York: The Macmillan Co. Inc.; Reprinted by Chelsea publ. Co.

2 Srivastava, H.M., \& Manocha, H.L. (1984). A Treatise on Generating Functions. Chichester, Brisbane and Toronto, New York: Halsted Press (Ellis Horwood Limited, Chichester), John Wiley and Sons.

3 Magnus, W., Oberhettinger, F., \& Soni, R.P. (1966). Some Formulas and Theorems for the Special Functions of Mathematical Physics: Third Enlarged Edition. New York: Springer-Verlag.

4 Gradshteyn, I.S., \& Ryzhik, I.M. (2007). Table of Integrals, Series and Products: Seventh Edition. New York: Academic Press.

5 Srivastava, H.M., \& Choi, J. (2011).Zeta and q-Zeta Functions and Associated Series and Integrals. Elsevier.

6 Luke, Y.L. (1969). The Special Functions and Their Approximations, Vol. I. New York: Academic Press.

7 Abramowitz, M., \& Stegun, I.A. (1992). Handbook of Mathematical Functions with Formulas, Graphs and Mathematical Tables, Reprint of the 1972 Edition. New York: Dover Publications, Inc.

8 Erdélyi, A., Magnus, W., Oberhettinger, F., \& Tricomi, F.G. (1955). Higher Transcendental Functions, Vol. I. Toronto and London, New York: McGraw-Hill Book Company.

9 Prudnikov, A.P., Brychknov, Yu. A., \& Marichev, O.I. (1990). Integrals and Series, Vol. III: More special functions, Nauka Moscow, 1986 (in Russian); (Translated from the Russian by G.G.Gould). Philadelphia London, Paris, Montreux, Tokyo, Melbourne, New York: Gordon and Breach Science Publishers.

10 Andrews, G.E., Askey, R., \& Roy, R. (1999). Special Functions. Cambridge, UK: Cambridge University Press.

11 Dougall, J. (1907). On Vandermonde's theorem and some more general expansions. Proc. Edinburg Math. Soc. 25, 114-132.

12 Slater, L.J. (1966). Generalized Hypergeometric Functions. New York: Cambridge Univ., Press.

13 Bailey, W.N. (1935). Generalized Hypergeometric Series. London: Cambridge University Press.

М.И. Куреши, Дж. Маджид, А.Х. Бхат

Джамия Миллия Исламия (Ортальқ, университет), Нью-Дели, Үндістан

\section{Гипергеометриялық функциялар мен жартылай бөлшек әдістерімен кейбір шексіз серияларды жинақтау}

\begin{abstract}
Мақалада кейбір шексіз қатарлардың жартылай бөлшек әдісімен оң және теріс сингулярлық дәлелдерді, Риманның Зета функцияларын, полигамма функцияларын, кіші регистрдегі бір айнымалының бета функцияларын және басқа да байланысты функцияларды жинақтаудың кейбір гипергеометриялық теоремалары жинақталған. Сондай-ақ кейбір гипергеометриялық жиынтық теоремалар алынған:

$$
\begin{gathered}
{ }_{8} F_{7}\left[\frac{9}{2}, \frac{3}{2}, \frac{3}{2}, \frac{3}{2}, \frac{3}{2}, 3,3,1 ; \frac{7}{2}, \frac{7}{2}, \frac{7}{2}, \frac{7}{2}, \frac{1}{2}, 2,2 ; 1\right],{ }_{5} F_{4}\left[\frac{5}{3}, \frac{4}{3}, \frac{4}{3}, \frac{1}{3}, \frac{1}{3} ; \frac{2}{3}, 1,2,2 ; 1\right],{ }_{5} F_{4}\left[\frac{9}{4}, \frac{5}{2}, \frac{3}{2}, \frac{1}{2}, \frac{1}{2} ; \frac{5}{4}, 2,3,3 ; 1\right] \\
{ }_{5} F_{4}\left[\frac{13}{8}, \frac{5}{4}, \frac{5}{4}, \frac{1}{4}, \frac{1}{4} ; \frac{5}{8}, 2,2,1 ; 1\right], \quad{ }_{5} F_{4}\left[\frac{1}{2}, \frac{1}{2}, \frac{5}{2}, \frac{5}{2}, 1 ; \frac{3}{2}, \frac{3}{2}, \frac{7}{2}, \frac{7}{2} ;-1\right], \quad{ }_{4} F_{3}\left[\frac{3}{2}, \frac{3}{2}, 1,1 ; \frac{5}{2}, \frac{5}{2}, 2 ; 1\right], \\
{ }_{4} F_{3}\left[\frac{2}{3}, \frac{1}{3}, 1,1 ; \frac{7}{3}, \frac{5}{3}, 2 ; 1\right],{ }_{4} F_{3}\left[\frac{7}{6}, \frac{5}{6}, 1,1 ; \frac{13}{6}, \frac{11}{6}, 2 ; 1\right] \text { and }{ }_{4} F_{3}[1,1,1,1 ; 3,3,3 ;-1] .
\end{gathered}
$$
\end{abstract}

Kiлm сөздер: Риманның Зета функциялары, полигамма функциялары, Дугалл теоремасы, Бернулли көпмүшелері, Каталан константасы. 
М.И. Куреши, Дж. Маджид, А.Х. Бхат

Джамия Миллия Исламия (Центральный университет), Нью-Дели, Индия

\section{Суммирование некоторых бесконечных рядов методами гипергеометрических функций и частных дробей}

В статье получено суммирование некоторых бесконечных рядов методом частичных дробей и с помощью некоторых гипергеометрических теорем суммирования положительных и отрицательных единичных аргументов, дзета-функций Римана, полигамма-функций, бета-функций одной переменной в нижнем регистре и других связанных функций. Кроме того, авторами получены некоторые гипергеометрические теоремы суммирования для:

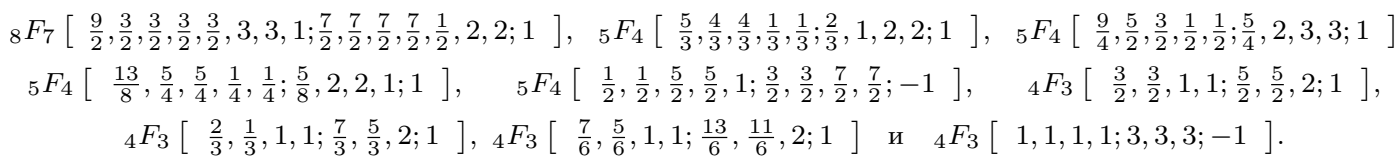

Ключевые слова: дзета-функции Римана, полигамма-функции, теорема Дугалла, многочлены Бернулли, константа Каталана. 
DOI $10.31489 / 2021 \mathrm{M} 3 / 96-104$

UDC 515.1

\author{
B. $\operatorname{Roy}^{1, *}$, T. Noiri ${ }^{2}$ \\ ${ }^{1}$ Women's Christian College, Kolkata, India \\ ${ }^{2}$ Yatsushiro, Japan \\ (E-mail: bishwambhar_roy@yahoo.co.in,t.noiri@nifty.com)
}

"Dedicated to Professor Filippo CAMMAROTO for his 70th Birthday"

\title{
Applications of operations on generalized topological spaces
}

\begin{abstract}
In this paper, $\gamma_{\mu}$-open sets and $\gamma_{\mu}$-closed sets in a $\operatorname{GTS}(X, \mu)$ have been studied, where $\gamma_{\mu}$ is an operation from $\mu$ to $\mathcal{P}(X)$. In general, collection of $\gamma_{\mu}$-open sets is smaller than the collection of $\mu$-open sets. The condition under which both are same are also established here. Some properties of such sets have been discussed. Some closure as operators are also defined and their properties are discussed. The relation between similar types of closure operators on the GTS $(X, \mu)$ has been established. The condition under which the newly defined closure like operator is a Kuratowski closure operator is given. We have also defined a generalized type of closed sets termed as $\gamma_{\mu}$-generalized closed set with the help of this newly defined closure operator and discussed some basic properties of such sets. As an application, we have introduced some weak separation axioms and discussed some of their properties. Finally, we have shown some preservation theorems of such generalized concepts.
\end{abstract}

Keywords: operation, $\mu$-open set, $\gamma_{\mu}$-open set, $\gamma_{\mu} g$-closed set.

\section{Introduction}

In 1979, Kasahara [1] introduced the notion of an operation on a topological space and introduced the concept of an $\alpha$-closed graph of a function. After then Janković defined [2] the concept of $\alpha$-closed sets and investigated some properties of functions with $\alpha$-closed graphs. In 1991 Ogata [3] introduced the notion of $\gamma$-open sets to investigate some new separation axioms of a topological space. Recently, Krishnan et al. [4] and Van An et al. [5] investigated the notion of operations on the family of all semi-open sets and pre-open sets.

In this paper our aim is to study an operation based on open like sets, where the operation is defined on a collection of generalized open sets instead of a topology. The family of open sets plays an important role in topology. For this, different open like sets or weakly open sets have been introduced by mathematicians to study different weak forms of continuous functions and covering properties of topological spaces. But the most common properties of these open like sets or weakly open sets are that they are closed under arbitrary union and contain the empty set. Observing these, Császár introduced the concept of generalized open sets. We now recall some notions defined in [6]. Let $X$ be a non-empty set. A subcollection $\mu \subseteq \mathcal{P}(X)$ (where $\mathcal{P}(X)$ denotes the power set of $X$ ) is called a generalized topology [6], (briefly, GT) if $\varnothing \in \mu$ and any union of elements of $\mu$ belongs to $\mu$. A set $X$ with a GT $\mu$ on the set $X$ is called a generalized topological space (briefly, GTS) and is denoted by $(X, \mu)$. If for a GTS $(X, \mu) X \in \mu$, then $(X, \mu)$ is known as a strong GTS. The elements of $\mu$ are called $\mu$-open sets and $\mu$-closed sets are their complements. The $\mu$-closure of a set $A \subseteq X$ is denoted by $c_{\mu}(A)$ and defined as the smallest $\mu$-closed set containing $A$ which is equivalent to the intersection of all $\mu$-closed sets containing $A$. It is also known from $[7,8]$ that for a $\operatorname{GTS}(X, \mu), A \subseteq X$ and $x \in X, x \in c_{\mu}(A)$ if and only if $U \cap A \neq \emptyset$ for every $U \in \mu$ containing $x$. We use the symbol $i_{\mu}(A)$ to mean the $\mu$-interior of $A$ and it is defined as the union of all $\mu$-open sets contained in $A$ i.e., the largest $\mu$-open set contained in $A$ (see [6, 7]). We observe that $x \in i_{\mu}(A)$ if and only if there exists some $\mu$-open set $U$ containing $x$ such that $U \subseteq A$ and $A \subseteq X$ is $\mu$-open (resp. $\mu$-closed) if and only if $A=i_{\mu}(A)$ (resp. $A=c_{\mu}(A)$ ). It is well known that $i_{\mu}$ and $c_{\mu}$ both are monotonic and idempotent. For any subset $A$ of a $\operatorname{GTS}(X, \mu), i_{\mu}(X \backslash A)=X \backslash c_{\mu}(A)$ holds.

Császár continued to try to find a more general structure from general topology, generalized topology, and minimal structure. In 2010, he introduced the notion of weak structures [9] and proved that it can replace the

\footnotetext{
${ }^{*}$ Corresponding author.

E-mail: bishwambhar_roy@yahoo.co.in
} 
already defined structures in some cases. A sub-collection $w \subseteq \mathcal{P}(X)$ is said to be a weak structure on $X$ if and only if it contains the empty set. Its properties have been investigated intensively in [10-13]. In Section 2 we have introduced the concept of a type of generalized open sets termed as $\gamma_{\mu}$-open sets, the class of which is smaller than that of generalized open sets, by an operator defined on a GT. We have then studied some properties of such sets in detail. In section 3 we have defined a new type of generalized closed sets and studied some separation properties with the help of the idea developed in Section 2.

\section{$\gamma_{\mu}$-open sets and operations}

Definition 2.1. [14] Let $(X, \mu)$ be a GTS. An operation $\gamma_{\mu}$ on a generalized topology $\mu$ is a mapping from $\mu$ to $\mathcal{P}(X)$ (where $\mathcal{P}(X)$ is the power set of $X$ ) with $G \subseteq \gamma_{\mu}(G)$ for each $G \in \mu$. This operation is denoted by $\gamma_{\mu}: \mu \rightarrow \mathcal{P}(X)$. Note that $\gamma_{\mu}(A)$ and $A^{\gamma_{\mu}}$ are two different notation for the same set.

Definition 2.2. [14] Let $(X, \mu)$ be a GTS and $\gamma_{\mu}$ an operation on $\mu$. A subset $G$ of a GTS $(X, \mu)$ is called $\gamma_{\mu}$-open if for each point $x$ of $G$, there exists a $\mu$-open set $U$ containing $x$ such that $\gamma_{\mu}(U) \subseteq G$.

A subset of a $\operatorname{GTS}(X, \mu)$ is called $\gamma_{\mu}$-closed if its complement is $\gamma_{\mu}$-open in $(X, \mu)$. We shall use the symbol $\gamma_{\mu}$ to mean the collection of all $\gamma_{\mu}$-open sets of the GTS $(X, \mu)$.

Remark 2.3. (a) We observe that every $\gamma_{\mu}$-open set is a $\mu$-open set i.e., $\gamma_{\mu} \subseteq \mu$. Let $G \in \gamma_{\mu}$. If $G=\varnothing$ then $G \in \mu$. If $G \neq \varnothing$, let $x \in G$. Then there exists a $\mu$-open set $U$ containing $x$ such that $\gamma_{\mu}(U) \subseteq G$. Thus for each $x \in G$ there exists a $\mu$-open set $U$ containing $x$ such that $x \in U \subseteq G$. Thus $x$ is a $\mu$-interior point of $G$ i.e., $x \in i_{\mu}(G)$ i.e., $G \subseteq i_{\mu}(G)$ proving $G$ to be a $\mu$-open set.

(b) We note that $\gamma_{\mu}$ is a GT on $X$ i.e., $\varnothing \in \gamma_{\mu}$ and arbitrary unions of $\gamma_{\mu}$-open sets are also $\gamma_{\mu}$-open. For let $\left\{G_{\alpha}: \alpha \in I\right\}$ be a family of $\gamma_{\mu}$-open subsets of $X$. We shall show that $\cup\left\{G_{\alpha}: \alpha \in I\right\}$ is also a $\gamma_{\mu}$-open set. In fact, let $x \in \cup\left\{G_{\alpha}: \alpha \in I\right\}$. Then $x \in G_{\alpha_{0}}$ for some $\alpha_{0} \in I$. Thus by $\gamma_{\mu}$-openness of $G_{\alpha_{0}}$, there exists a $\mu$-open set $U$ containing $x$ such that $\gamma_{\mu}(U) \subseteq G_{\alpha_{0}} \subseteq \cup\left\{G_{\alpha}: \alpha \in I\right\}$.

Example 2.4. (a) Let $X=\{1,2,3\}$ and $\mu=\{\varnothing,\{1,2\},\{1,3\}, X\}$. Then $\mu$ is a GT on $X$. Consider the mapping $\gamma_{\mu}: \mu \rightarrow \mathcal{P}(X)$ defined by $\gamma_{\mu}(A)=c_{\mu}(A)$ for each subset $A$ of $X$. It can be easily checked that $\{1,2\}$ is a $\mu$-open set but not a $\gamma_{\mu}$-open set.

(b) Let $X=\{1,2,3\}$ and $\mu=\{\varnothing,\{1\},\{1,2\},\{2,3\}, X\}$. Then $(X, \mu)$ is a GTS. Now $\gamma_{\mu}: \mu \rightarrow \mathcal{P}(X)$ defined by

$$
\gamma_{\mu}(A)=\left\{\begin{array}{c}
A, \text { if } 1 \in A \\
\{2,3\}, \text { otherwise }
\end{array}\right.
$$

is an operation. It can be easily checked that $\{1,2\}$ and $\{2,3\}$ are two $\gamma_{\mu}$-open sets but their intersection $\{2\}$ is not so.

Definition 2.5. A GTS $(X, \mu)$ is said to be a $\gamma_{\mu}$-regular space if for each point $x$ of $X$ and each $\mu$-open set $V$ containing $x$, there exists a $\mu$-open set $U$ containing $x$ such that $\gamma_{\mu}(U) \subseteq V$.

Theorem 2.6. Let $(X, \mu)$ be a GTS and $\gamma_{\mu}: \mu \rightarrow \mathcal{P}(X)$ be an operation on a GTS $X$. Then $(X, \mu)$ is a $\gamma_{\mu}$-regular space if and only if $\mu=\gamma_{\mu}$.

Proof. Let $(X, \mu)$ be a $\gamma_{\mu}$-regular space. In view of Remark 2.3 it is sufficient to show that $\mu \subseteq \gamma_{\mu}$. Let $G$ be a $\mu$-open set of $X$. If $G=\varnothing$, then $G \in \gamma_{\mu}$. Thus we may assume that $G \neq \varnothing$. Since $(X, \mu)$ is $\gamma_{\mu}$-regular, then $G$ is a $\gamma_{\mu}$-open set. Therefore, we have $\mu \subseteq \gamma_{\mu}$.

Conversely, let $x \in X$ and $V$ be a $\mu$-open set containing $x$. Then $V$ is a $\gamma_{\mu}$-open set containing $x\left(\right.$ as $\left.\mu=\gamma_{\mu}\right)$. Thus by definition of $\gamma_{\mu}$-open sets, there exists a $\mu$-open set $U$ containing $x$ such that $\gamma_{\mu}(U) \subseteq V$. Hence $(X, \mu)$ is a $\gamma_{\mu}$-regular space.

Theorem 2.7. A GTS $(X, \mu)$ is a $\gamma_{\mu}$-regular space if and only if for each point $x \in X$ and every $\mu$-open set $U$ containing $x$, there exists a $\gamma_{\mu}$-open set $W$ containing $x$ such that $W \subseteq U$.

Proof. First let us assume that $(X, \mu)$ be a $\gamma_{\mu}$-regular space. Let $x \in \overline{\bar{X}}$ and $U$ be a $\mu$-open set containing $x$. Then by Definition 2.5, there exists a $\mu$-open set $W$ containing $x$ such that $W \subseteq \gamma_{\mu}(W) \subseteq U$. Thus by Theorem 2.6, $W$ is a $\gamma_{\mu}$-open set. Hence there exists a $\gamma_{\mu}$-open set $W$ such that $x \in W \cong U$.

Conversely, suppose that for each point $x \in X$ and every $\mu$-open set $U$ containing $x$ there exists a $\gamma_{\mu}$-open set $W$ containing $x$ such that $W \subseteq U$. In view of Theorem 2.6 and Remark 2.3(a) it is now sufficient to show that $\mu \subseteq \gamma_{\mu}$. Let $U \in \mu$ and $x \in \bar{U}$. Then by the given condition there exists a $\gamma_{\mu}$-open set $W_{x}$ containing $x$ such that $W_{x} \subseteq U$. Thus $U=\cup\left\{W_{x}: x \in U\right.$ and $W_{x}$ is $\gamma_{\mu}$-open $\}$. Thus by Remark 2.3(b), $U$ is $\gamma_{\mu}$-open.

Definition 2.8. Let $(X, \mu)$ be a GTS. An operation $\gamma_{\mu}: \mu \rightarrow \mathcal{P}(X)$ is said to be regular if for each point $x \in X$ and any two $\mu$-open sets $U$ and $V$ of $X$ containing $x$ there exists a $\mu$-open set $W$ containing $x$ such that $\gamma_{\mu}(W) \subseteq \gamma_{\mu}(U) \cap \gamma_{\mu}(V)$. 
Theorem 2.9. Let $\gamma_{\mu}: \mu \rightarrow \mathcal{P}(X)$ be a regular operation. Then the intersection of two $\gamma_{\mu}$-open sets is also a $\gamma_{\mu}$-open set. Furthermore, $\gamma_{\mu}$ is a topology if $X \in \mu$.

Proof. Let $G$ and $H$ be two $\gamma_{\mu}$-open sets in a GTS $(X, \mu)$. We shall show that $G \cap H$ is also a $\gamma_{\mu}$-open set. If $G \cap H=\varnothing$ then the proof is done. Let $x \in G \cap H$. Then by Definition 2.2, there exist two $\mu$-open sets $U$ and $V$ with $x \in U \cap V$ such that $\gamma_{\mu}(U) \subseteq G$ and $\gamma_{\mu}(V) \subseteq H$. Since $\gamma_{\mu}: \mu \rightarrow \mathcal{P}(X)$ is a regular operation, there exists a $\mu$-open set $W$ containing $x$ such that $\gamma_{\mu}(W) \subseteq \gamma_{\mu}(U) \cap \gamma_{\mu}(V) \subseteq G \cap H$. Thus by Definition $2.2, G \cap H$ is $\gamma_{\mu}$-open.

If $X \in \mu$, then for each $x \in X$, there exists a $\mu$-open set $X$ (as $X \in \mu$ ) containing $x$ such that $X \subseteq \gamma_{\mu}(X) \subseteq X$. Thus $X$ is a $\gamma_{\mu}$-open set. It follows from Remark 2.3(b) that arbitrary union of $\gamma_{\mu}$-open sets is a $\gamma_{\mu}$-open set. Thus $\gamma_{\mu}$ is a topology on $X$.

Example 2.10. (a) Let $X=\{1,2,3\}$ and $\mu=\{\varnothing,\{1\},\{2\},\{1,2\}\}$. Then $\gamma_{\mu}: \mu \rightarrow \mathcal{P}(X)$ defined by $\gamma_{\mu}(A)=c_{\mu}(A)$ is an operation on the GTS $(X, \mu)$ where $\mu$ is not strong. It can be easily checked the $X$ is not a $\gamma_{\mu}$-open set. We note that $\gamma_{\mu}: \mu \rightarrow \mathcal{P}(X)$ is a regular operation.

(b) Let $X=\{1,2,3\}, \mu=\{\varnothing, X,\{2\},\{1,3\},\{2,3\}\}$. Then $\gamma_{\mu}: \mu \rightarrow \mathcal{P}(X)$ defined by

$$
\gamma_{\mu}(A)=\left\{\begin{array}{l}
A \cup\{1\}, \text { if } A \text { is any singleton subset of } X \\
A, \text { otherwise }
\end{array}\right.
$$

is an operation on the GTS $(X, \mu)$. We note that $\gamma_{\mu}$ is not a regular operation. It can be checked easily that $\gamma_{\mu}$ is not a topology on $X$.

We now define the following two types of closure operators : one follows from the GT $\gamma_{\mu}$ on $X$ and the second one is defined in the sense of Jankovič.

Definition 2.11. Let $(X, \mu)$ be a GTS and $\gamma_{\mu}: \mu \rightarrow \mathcal{P}(X)$ be an operation.

(a) It follows from Remark 2.3(b) that $\gamma_{\mu}$ is a GT. Thus the $\gamma_{\mu}$-closure of a set $A$ is denoted by $c_{\gamma_{\mu}}(A)$ and is defined as $c_{\gamma_{\mu}}(A)=\cap\left\{F: F\right.$ is a $\gamma_{\mu}$-closed set and $\left.A \subseteq F\right\}$.

(b) $\gamma_{\mu}^{*}$-closure of $A$ is denoted by $\gamma_{\mu}-c(A)$ and defined by $\gamma_{\mu}-c(A)=\left\{x: A \cap \gamma_{\mu}(U) \neq \varnothing\right.$ for every $\mu$-open set $U$ containing $x\}$.

A subset $A(\subseteq X)$ is called $\gamma_{\mu}^{*}$-closed if $\gamma_{\mu}-c(A)=A$.

Proposition 2.12. Let $(X, \mu)$ be a GTS and $\gamma_{\mu}: \mu \rightarrow \mathcal{P}(X)$ be an operation. For each $x \in X, x \in c_{\gamma_{\mu}}(A)$ if and only if $V \cap A \neq \varnothing$ for any $V \in \gamma_{\mu}$ with $x \in V$.

Proof. The proof follows from the fact that $\gamma_{\mu}$ is a GT on $X$ ( by Remark 2.3(b)) and the fact that for any GT $\mu$ on $X, x \in c_{\mu}(A)[7,8]$ if and only if $U \cap A \neq \varnothing$ for each $\mu$-open set $U$ containing $x$.

Remark 2.13. It can be checked easily that for any subset $A$ of a GTS $(X, \mu), A \subseteq c_{\mu}(A) \subseteq \gamma_{\mu}-c(A) \subseteq c_{\gamma_{\mu}}(A)$.

Definition 2.14. An operation $\gamma_{\mu}: \mu \rightarrow \mathcal{P}(X)$ is said to be $\mu$-open if for each point $x$ of $X$ and for every $\mu$-open set $U$ containing $x$ there exists a $\gamma_{\mu}$-open set $V$ containing $x$ such that $V \cong \gamma_{\mu}(U)$.

The next theorem gives the relation between the three types of closure operators.

Theorem 2.15. Let $(X, \mu)$ be a GTS, $\gamma_{\mu}: \mu \rightarrow \mathcal{P}(X)$ an operation and $A$ a subset of $X$.

(i) The subset $\gamma_{\mu}-c(A)$ is $\mu$-closed in $(X, \mu)$.

(ii) If $(X, \mu)$ is $\gamma_{\mu}$-regular, then $\gamma_{\mu}-c(A)=c_{\mu}(A)$.

(iii) If $\gamma_{\mu}$ is $\mu$-open, then $\gamma_{\mu}-c(A)=c_{\gamma_{\mu}}(A)$ and $\gamma_{\mu}-c\left[\gamma_{\mu}-c(A)\right]=\gamma_{\mu}-c(A)$.

Proof. (i) We shall only show that $c_{\mu}\left[\gamma_{\mu}-c(A)\right] \subseteq \gamma_{\mu}-c(A)$. Let $x \in c_{\mu}\left[\gamma_{\mu}-c(A)\right]$ and $U$ be any $\mu$-open set in $X$ containing $x$. Then $U \cap \gamma_{\mu}-c(A) \neq \varnothing$. Let $y \in U \cap \gamma_{\mu}-c(A)$. Then $y \in U$ and $y \in \gamma_{\mu}-c(A)$. Thus $\gamma_{\mu}(U) \cap A \neq \varnothing$ i.e., $x \in \gamma_{\mu}-c(A)$ (by Definition 2.11).

(ii) In view of Remark 2.13 we need only to show that in a $\gamma_{\mu}$-regular GTS $(X, \mu), \gamma_{\mu}-c(A) \subseteq c_{\mu}(A)$. Let $x \in \gamma_{\mu}-c(A)$ and $G$ be any $\mu$-open set containing $x$. Then there exists a $\mu$-open set $U$ containing $x$ such that $\gamma_{\mu}(U) \subseteq G\left(\right.$ as $(X, \mu)$ is $\gamma_{\mu}$-regular). Since $x \in \gamma_{\mu}-c(A)$ we have $\gamma_{\mu}(U) \cap A \neq \varnothing$ and hence $G \cap A \neq \varnothing$. Thus it follows that $x \in c_{\mu}(A)$.

(iii) Suppose that $x \notin \gamma_{\mu}-c(A)$. Then there exists a $\mu$-open set $U$ containing $x$ such that $\gamma_{\mu}(U) \cap A=\varnothing$. Since $\gamma_{\mu}$ is $\mu$-open, for the $\mu$-open set $U$ containing $x$, there exists a $\gamma_{\mu}$-open set $V$ containing $x$ such that $V \subseteq \gamma_{\mu}(U)$. Hence $V \cap A=\varnothing$. This shows that $x \notin c_{\gamma_{\mu}}(A)$. Thus $c_{\gamma_{\mu}}(A) \subseteq \gamma_{\mu}-c(A)$. Also from Remark 2.13, $\gamma_{\mu}-c(A) \subseteq c_{\gamma_{\mu}}(A)$. Thus we have $\gamma_{\mu}-c(A)=c_{\gamma_{\mu}}(A)$. Hence $\gamma_{\mu}-c\left[\gamma_{\mu}-c(A)\right]=c_{\gamma_{\mu}}\left[c_{\gamma_{\mu}}(A)\right]=c_{\gamma_{\mu}}(A)$ (as $\gamma_{\mu}$ is a GT on $X$ and $c_{\gamma_{\mu}}$ is idempotent $)=\gamma_{\mu}-c(A)$. by

Example 2.16. (a) Let $X=\{1,2,3\}, \mu=\{\varnothing,\{1\},\{3\},\{1,2\},\{1,3\},\{2,3\}, X\}$. Then $\gamma_{\mu}: \mu \rightarrow \mathcal{P}(X)$ defined

$$
\gamma_{\mu}(A)=\left\{\begin{array}{l}
A \cup\{3\}, \text { if } A \neq\{1\} \\
A, \text { otherwise }
\end{array}\right.
$$


is an operation. It can be easily checked that $c_{\mu}(\{3\})=\{3\} \neq \gamma_{\mu}-c(\{3\})=\{2,3\}$ and thus from Theorem 2.15 it follows that $(X, \mu)$ is not $\gamma_{\mu}$-regular.

(b) Let $X=\{1,2,3,4\}, \mu=\{\varnothing,\{1,2\},\{2,3\},\{1,4\},\{1,2,3\},\{1,2,4\},\{2,3,4\}, X\}$. Then $\gamma_{\mu}: \mu \rightarrow \mathcal{P}(X)$ defined by

$$
\gamma_{\mu}(A)=\left\{\begin{array}{l}
A, \text { if } 1 \in A \\
A \cup\{1\}, \text { if } 1 \notin A
\end{array}\right.
$$

is an operation. It can be checked that $\gamma_{\mu}-c(\{2\})=\{2,3,4\}$ but $\gamma_{\mu}-c\left[\gamma_{\mu}-c(\{2\})\right]=X \neq \gamma_{\mu}-c(\{2\})$. Thus it follows from Theorem 2.15 that $\gamma_{\mu}$ is not $\mu$-open.

Theorem 2.17. Let $\mu$ be a GT on a set $X$ and $\gamma_{\mu}: \mu \rightarrow \mathcal{P}(X)$ be an operation. For any subset $A$ of $X$ the followings are equivalent :

(i) $A$ is $\gamma_{\mu}$-open in $(X, \mu)$.

(ii) $X \backslash A$ is $\gamma_{\mu}^{*}$-closed in $(X, \mu)$.

(iii) $c_{\gamma_{\mu}}(X \backslash A)=X \backslash A$ holds.

(iv) $X \backslash A$ is $\gamma_{\mu}$-closed in $(X, \mu)$.

Proof. (i) $\Rightarrow$ (ii): Let $x \notin X \backslash A$. Then $x \in A$. Thus there exists a $\mu$-open set $U$ containing $x$ such that $\gamma_{\mu}(U) \subseteq A$ i.e., $\gamma_{\mu}(U) \cap(X \backslash A)=\varnothing$. This shows that $x \notin \gamma_{\mu}-c(X \backslash A)$. Thus it follows that $\gamma_{\mu}-c(X \backslash A) \subseteq X \backslash A$.

(ii) $\Rightarrow$ (iii): We have to show that $c_{\gamma_{\mu}}(X \backslash A) \subseteq X \backslash A$. Let $x \notin X \backslash A$. It then follows from (ii) that there exists a $\mu$-open set $U$ containing $x$ such that $\gamma_{\mu}(U) \cap(X \backslash A)=\varnothing$. Then $A$ is a $\gamma_{\mu}$-open set containing $x$. Therefore $A \cap(X \backslash A)=\varnothing$ and hence $x \notin c_{\gamma_{\mu}}(X \backslash A)$.

(iii) $\Rightarrow$ (iv): We shall show that $A$ is $\gamma_{\mu}$-open. Let $x \in A$. Then by Proposition 2.12 and (iii), there exists a $\gamma_{\mu}$-open set $U$ containing $x$ such that $U \cap(X \backslash A)=\varnothing$. Since $U$ is $\gamma_{\mu}$-open and $x \in U$, there exists a $\mu$-open set $V$ containing $x$ such that $\gamma_{\mu}(V) \subseteq U$. Thus we have $x \in \gamma_{\mu}(V) \subseteq U \subseteq A$ and hence $A$ is $\gamma_{\mu}$-open.

(iv) $\Rightarrow$ (i) : The proof follows from the definition.

Theorem 2.18. Let $(X, \mu)$ be a GTS and $\gamma_{\mu}: \mu \rightarrow \mathcal{P}(X)$ be an operation. If $\gamma_{\mu}$ is regular, then $\gamma_{\mu}-c(A \cup B)=\gamma_{\mu}-c(A) \cup \gamma_{\mu}-c(B)$ for any two subsets $A$ and $B$ of $X$.

Proof. Let $x \notin \gamma_{\mu}-c(A) \cup \gamma_{\mu}-c(B)$. Then $x \notin \gamma_{\mu}-c(A)$ and $x \notin \gamma_{\mu}-c(B)$. Hence there exist two $\mu$-open sets $U$ and $V$ containing $x$ such that $\gamma_{\mu}(U) \cap A=\gamma_{\mu}(V) \cap B=\varnothing$. Since $\gamma_{\mu}$ is regular, there exists a $\mu$-open set $W$ containing $x$ such that $\gamma_{\mu}(W) \subseteq \gamma_{\mu}(U) \cap \gamma_{\mu}(V)$. Therefore, we have $(A \cup B) \cap \gamma_{\mu}(W) \subseteq(A \cup B) \cap\left[\gamma_{\mu}(U) \cap \gamma_{\mu}(V)\right] \subseteq$ $\subseteq\left[A \cap \gamma_{\mu}(U)\right] \cup\left[B \cap \gamma_{\mu}(V)\right]=\varnothing$. Hence $x \notin \gamma_{\mu}-c(A \cup B)$. Therefore, we obtain $\gamma_{\mu}-c(A \cup B) \subseteq \gamma_{\mu}-c(A) \cup \gamma_{\mu}-c(B)$.

Corollary 2.19. Let $\mu$ be a GT on a set $X$ and $\gamma_{\mu}: \mu \rightarrow \mathcal{P}(X)$ be an operation. If $\gamma_{\mu}$ is regular and $\mu$-open, then the mapping defined by $\psi(A)=\gamma_{\mu}-c(A)$ for $A \cong X$ is a Kuratowski closure operator.

Proof. This follows from Theorem 2.15, Theorem 2.18 and Definition 2.11.

$$
\gamma_{\mu} \text {-generalized closed sets and } \gamma_{\mu}-T_{i} \text { spaces }(i=0,1 / 2,1,2)
$$

Definition 3.1. Let $\gamma_{\mu}: \mu \rightarrow \mathcal{P}(X)$ be an operation. A subset $A$ of a GTS $(X, \mu)$ is said to be $\gamma_{\mu}$-generalized closed (briefly $\gamma_{\mu} g$-closed) if $\gamma_{\mu}-c(A) \subseteq U$ whenever $A \subseteq U$ and $U$ is $\gamma_{\mu}$-open.

The complement of a $\gamma_{\mu} g$-closed set is called a $\gamma_{\mu} g$-open set.

We observe that every $\gamma_{\mu}^{*}$-closed set is $\gamma_{\mu} g$-closed. The converse is false as shown in the next example. by

Example 3.2. Consider $X=\{1,2,3\}, \mu=\{\varnothing,\{1\},\{3\},\{1,2\},\{1,3\},\{2,3\}\}$. Then $\gamma_{\mu}: \mu \rightarrow \mathcal{P}(X)$ defined

$$
\gamma_{\mu}(A)=\left\{\begin{array}{l}
A \cup\{2\}, \text { if } A \neq\{1\} \\
A, \text { otherwise }
\end{array}\right.
$$

is an operation. It can be checked easily that $\{1,3\}$ is $\gamma_{\mu} g$-closed but not $\gamma_{\mu}$-closed.

The following theorem gives the characterizations of $\gamma_{\mu} g$-closed sets.

Theorem 3.3. Let $\gamma_{\mu}: \mu \rightarrow \mathcal{P}(X)$ be an operation. Then for any $A \subseteq X$, the following are equivalent:

(i) $A$ is $\gamma_{\mu} g$-closed.

(ii) For each $x \in \gamma_{\mu}-c(A), c_{\gamma_{\mu}}(\{x\}) \cap A \neq \varnothing$.

(iii) $\gamma_{\mu}-c(A) \subseteq \operatorname{Ker}_{\gamma_{\mu}}(A)$ (where $\operatorname{Ker}_{\gamma_{\mu}}(A)=\cap\left\{V: A \subseteq V\right.$ and $V$ is $\gamma_{\mu}$-open $\}$ see [15] for detail).

Proof. (i) $\Rightarrow$ (ii) : Suppose that $A$ be a $\gamma_{\mu} g$-closed subset and also suppose that there exists a point $x \in \gamma_{\mu}-c(A)$ for which $c_{\gamma_{\mu}}(\{x\}) \cap A=\varnothing$. Then $c_{\gamma_{\mu}}(\{x\})$ is $\gamma_{\mu}$-closed (by Remark 2.3(b) and Definition 2.11(a)). Put $U=X \backslash c_{\gamma_{\mu}}(\{x\})$. Then $A \subseteq U$ and $x \notin U$ with $U$ a $\gamma_{\mu}$-open set in $(X, \mu)$. Since $A$ is $\gamma_{\mu} g$-closed, $\gamma_{\mu}-c(A) \subseteq U$. Thus $x \notin \gamma_{\mu}-c(A)$ which is a contradiction. 
(ii) $\Rightarrow$ (iii) : Let $x \in \gamma_{\mu}-c(A)$. We have only to show that $x \in \operatorname{Ker}_{\gamma_{\mu}}(A)$. By (ii) there exists a point $z \in A$ such that $z \in c_{\gamma_{\mu}}(\{x\})$. Let $U$ be any $\gamma_{\mu}$-open subset of $X$ such that $A \subseteq U$. Since $z \in U$ and $z \in c_{\gamma_{\mu}}(\{x\})$, by Proposition 2.12 we have $U \cap\{x\} \neq \varnothing$ i.e., $x \in U$. Thus $x \in \operatorname{Ker}_{\gamma_{\mu}}(A)$.

(iii) $\Rightarrow$ (i) : Let $A \subseteq U$, where $U$ be any $\gamma_{\mu}$-open set. Let $x \in \gamma_{\mu}-c(A)$. It then follows from (iii) that $x \in \operatorname{Ker}_{\gamma_{\mu}}(A)$. Thus $x \in U$ i.e., $\gamma_{\mu}-c(A) \subseteq U$.

Theorem 3.4. Let $\gamma_{\mu}: \mu \rightarrow \mathcal{P}(X)$ be an operation, where $(X, \mu)$ is a GTS. For each point $x$ of $X,\{x\}$ is a $\gamma_{\mu}$-closed set or $X \backslash\{x\}$ is a $\gamma_{\mu} g$-closed set in $(X, \mu)$.

Proof. Let $\{x\}$ be not a $\gamma_{\mu}$-closed set. Then the complement $X \backslash\{x\}$ is not a $\gamma_{\mu}$-open set. Let $U$ be any $\gamma_{\mu}$-open set with $X \backslash\{x\} \subseteq U$. Then $U$ must be equal to $X$. Thus $\gamma_{\mu}-c(X \backslash\{x\}) \subseteq U$. Thus $X \backslash\{x\}$ is $\gamma_{\mu} g$-closed.

Proposition 3.5. Let $\gamma_{\mu}: \mu \rightarrow \mathcal{P}(X)$ be an operation and $A$ be a subset of a GTS $(X, \mu)$. If $A$ is $\gamma_{\mu} g$-closed, then $\gamma_{\mu}-c(A) \backslash A$ does not contain any non-empty $\gamma_{\mu}$-closed set. If the operation $\gamma_{\mu}: \mu \rightarrow \mathcal{P}(X)$ is $\mu$-open, then the converse part is also true.

Proof. If possible, let $F$ be any $\gamma_{\mu}$-closed set contained in $\gamma_{\mu}-c(A) \backslash A$. Then $A \subseteq X \backslash F$ where $X \backslash F$ is a $\gamma_{\mu}$-open set. Thus $\gamma_{\mu}-c(A) \subseteq X \backslash F$ (as $A$ is $\gamma_{\mu} g$-closed). Thus $F \subseteq X \backslash \gamma_{\mu}-c(A)$. Also $F \subseteq \gamma_{\mu}-c(A)$. Thus $F \stackrel{\text { ㅇ․ }}{=} \gamma_{\mu}-c(A) \cap\left(X \backslash \gamma_{\mu}-c(A)\right)=\varnothing$, which is a contradiction. Thus $F=\varnothing$.

Conversely, let $A \subseteq U$ where $U$ be any $\gamma_{\mu}$-open set. Since the operation $\gamma_{\mu}$ is $\mu$-open, by Theorem 2.15 $\gamma_{\mu}-c(A)$ is $\gamma_{\mu}$-closed. Thus $\gamma_{\mu}-c(A) \cap(X \backslash U)=F$ (say) is a $\gamma_{\mu}$-closed set (by Remark 2.3(b) and Definition 2.11(a)). Since $X \backslash U \subseteq X \backslash A, F \leqq \gamma_{\mu}-c(A) \backslash A$. Thus by the assumption it follows that $F=\varnothing$ and hence we have $\gamma_{\mu}-c(A) \subseteq U$.

Definition 3.6. Let $\gamma_{\mu}: \mu \rightarrow \mathcal{P}(X)$ be an operation, where $\mu$ is a GT on $X$. Then $(X, \mu)$ is said to be a $\gamma_{\mu}-T_{1 / 2}$ space if every $\gamma_{\mu} g$-closed set is a $\gamma_{\mu}$-closed set.

The next theorem characterizes a $\gamma_{\mu}-T_{1 / 2}$ GTS.

Theorem 3.7. Let $\gamma_{\mu}: \mu \rightarrow \mathcal{P}(X)$ be an operation, where $\mu$ is a GT on $X$. Then $(X, \mu)$ is $\gamma_{\mu}-T_{1 / 2}$ if and only if for each $x \in X,\{x\}$ is either $\gamma_{\mu}$-open or $\gamma_{\mu}$-closed.

Proof. Suppose that that $(X, \mu)$ is $\gamma_{\mu}-T_{1 / 2}$ and $\{x\}$ is not $\gamma_{\mu}$-closed. Then by Theorem 3.4, $X \backslash\{x\}$ is $\gamma_{\mu} g$-closed. Since $(X, \mu)$ is $\gamma_{\mu}-T_{1 / 2}, X \backslash\{x\}$ is $\gamma_{\mu}$-closed. Thus $\{x\}$ is $\gamma_{\mu}$-open.

Conversely, let $F$ be a $\gamma_{\mu} g$-closed set in $(X, \mu)$. By Theorem 2.17, it is sufficient to show that $\gamma_{\mu}-c(F) \subseteq F$. If possible, let there exist a point $x \in \gamma_{\mu}-c(F) \backslash F$. Then by the given condition $\{x\}$ is either $\gamma_{\mu}$-open or $\gamma_{\mu}$-closed. Case $-1:\{x\}$ is $\gamma_{\mu}$-closed : For this case we have a $\gamma_{\mu}$-closed set $\{x\}$ such that $\{x\} \subseteq \gamma_{\mu}-c(F) \backslash F$. This is contrary to Proposition 3.5 .

Case $-2:\{x\}$ is $\gamma_{\mu}$-open : Then by Remark 2.13, $x \in c_{\gamma_{\mu}}(F)$. Thus $\{x\} \cap F \neq \varnothing$. This is a contradiction. Thus we have $\gamma_{\mu}-c(F) \subseteq F$.

Definition 3.8. Let $\gamma_{\mu}: \mu \rightarrow \mathcal{P}(X)$ be an operation, where $\mu$ is a GT on $X$. Then $(X, \mu)$ is said to be (a) $\gamma_{\mu}-T_{0}$ if for each pair of distinct points $x, y \in X$, there exists a $\mu$-open set $G$ such that either $x \in G$ and $y \notin \gamma_{\mu}(G)$, or $y \in G$ and $x \notin \gamma_{\mu}(G)$.

(b) $\gamma_{\mu}-T_{1}$ if for each pair of distinct points $x, y \in X$, there exist $\mu$-open sets $G$ and $H$ containing $x$ and $y$, respectively, such that either $y \notin \gamma_{\mu}(G)$ and $x \notin \gamma_{\mu}(H)$.

(c) $\gamma_{\mu}-T_{2}$ if for each pair of distinct points $x, y \stackrel{\mu}{\in} X$, there exist $\mu$-open sets $G$ and $H$ containing $x$ and $y$, respectively, such that $\gamma_{\mu}(G) \cap \gamma_{\mu}(H)=\varnothing$.

A $\gamma_{\mu}-T_{1}$ GTS is characterized by the following theorem.

Theorem 3.9. Let $\gamma_{\mu}: \mu \rightarrow \mathcal{P}(X)$ be an operation, where $\mu$ is a GT on $X$. Then the following are equivalent:

(i) $(X, \mu)$ is $\gamma_{\mu}-T_{1}$.

(ii) For each $x \in X,\{x\}$ is a $\gamma_{\mu}^{*}$-closed set.

(iii) For each pair of distinct points $x, y \in X$ there exist $\gamma_{\mu}$-open sets $U$ and $V$ containing $x$ and $y$, respectively, such that either $y \notin U$ and $x \notin V$.

Proof. (i) $\Rightarrow$ (ii) : Let $x \in X$. We shall show that $\{x\}$ is $\gamma_{\mu}^{*}$-closed. Let $y \notin\{x\}$. Then by (i) there exists a $\mu$-open set $U_{y}$ such that $y \in U_{y}, x \notin \gamma_{\mu}\left(U_{y}\right)$. Thus $\gamma_{\mu}\left(U_{y}\right) \cap\{x\}^{\mu}=\varnothing$. Thus $y \notin \gamma_{\mu}-c(\{x\})$. Thus $\{x\}$ is $\gamma_{\mu}^{*}$-closed.

(ii) $\Rightarrow$ (iii) Let $x$ and $y$ be two points of $X$ with $x \neq y$. Then by (ii) $\{x\}$ and $\{y\}$ are two $\gamma_{\mu}$-closed sets and hence by Theorem 2.17, X\\{y\} and $X \backslash\{x\}$ are two $\gamma_{\mu}$-open sets containing $x$ and $y$, respectively, such that $x \in(X \backslash\{y\})$ and $y \in(X \backslash\{x\})$.

(iii) $\Rightarrow$ (i) : Obvious.

Let $\gamma_{\mu}: \mu \rightarrow \mathcal{P}(X)$ be an operation, where $\mu$ is a GT on $X$. Then it follows from Definitions 3.6 and 3.8 that $\gamma_{\mu}-T_{2} \Rightarrow \gamma_{\mu}-T_{1} \Rightarrow \gamma_{\mu}-T_{1 / 2} \Rightarrow \gamma_{\mu}-T_{0}$. None of the implications are reversible as shown in the next example. 
Example 3.10. (a) Let $X=\{1,2,3\}$ and $\mu=\mathcal{P}(X)$. Then $\mu$ is a GT on $X$. Then $\gamma_{\mu}: \mu \rightarrow \mathcal{P}(X)$ defined by

$$
\gamma_{\mu}(A)=\left\{\begin{array}{l}
A \cup\{2\}, \text { if } A=\{1\} \\
A \cup\{3\}, \text { if } A=\{2\} \\
A \cup\{1\}, \text { if } A=\{3\} \\
A, \text { otherwise }
\end{array}\right.
$$

is an operation. It can be checked that $(X, \mu)$ is $\gamma_{\mu}-T_{1}$ but not a $\gamma_{\mu}-T_{2}$ space.

(b) Let $X=\{1,2,3\}$ and $\mu=\mathcal{P}(X)$. Then $\mu$ is a GT on $X$. Then $\gamma_{\mu}: \mu \rightarrow \mathcal{P}(X)$ defined by

$$
\gamma_{\mu}(A)=\left\{\begin{array}{l}
A \cup\{3\}, \text { if } A \neq\{1\} \\
A, \text { otherwise }
\end{array}\right.
$$

is an operation. It can be checked that $(X, \mu)$ is $\gamma_{\mu}-T_{1 / 2}$ but not a $\gamma_{\mu}-T_{1}$ space.

(c) Let $X=\{1,2,3\}$ and $\mu=\{\varnothing,\{1\},\{1,2\},\{1,3\}, X\}$. Then $\mu$ is a GT on $X$. Then $\gamma_{\mu}: \mu \rightarrow \mathcal{P}(X)$ defined by

$$
\gamma_{\mu}(A)=\left\{\begin{array}{c}
A, \text { if } A \neq\{1\} \\
\{1,2\}, \text { otherwise }
\end{array}\right.
$$

is an operation. It can be checked that $(X, \mu)$ is $\gamma_{\mu}-T_{0}$ but not a $\gamma_{\mu}-T_{1 / 2}$ space.

Throughout the rest of the paper $(X, \mu)$ and $(Y, \lambda)$ will denote GTS's and $\gamma_{\mu}: \mu \rightarrow \mathcal{P}(X)$ and $\beta_{\lambda}: \lambda \rightarrow \mathcal{P}(Y)$ will denote two operations on $\mu$ and $\lambda$ respectively.

Definition 3.11. A function $f:(X, \mu) \rightarrow(Y, \lambda)$ is said to be $(\gamma, \beta)$-continuous if for each $x \in X$ and each $\lambda$-open set $V$ with $f(x) \in V$ there exists a $\mu$-open set $U$ containing $x$ such that $f\left(\gamma_{\mu}(U)\right) \subseteq \beta_{\lambda}(V)$.

Theorem 3.12. A $(\gamma, \beta)$-continuous mapping $f:(X, \mu) \rightarrow(Y, \lambda)$ satisfies the following properties:

(i) $f\left(\gamma_{\mu}-c(A)\right) \subseteq \beta_{\lambda}-c(f(A))$ for every subset $A$ of $X$.

(ii) $f^{-1}(W)$ is $\gamma_{\mu}$-open for every $\beta_{\lambda}$-open set $W$ of $Y$, i.e., the inverse image of any $\beta_{\lambda}$-closed set of $(Y, \beta)$ is $\gamma_{\mu}$-closed in $(X, \mu)$.

Proof. (i) Let $y$ be a point of $f\left(\gamma_{\mu}-c(A)\right)$ and $V$ be any $\lambda$-open set containing $y$. Then there exists a point $x$ in $X$ such that $f(x)=y$ and $x \in \gamma_{\mu}-c(A)$. Thus by $(\gamma, \beta)$-continuity of $f$ there exists a $\mu$-open set $U$ containing $x$ such that $f\left(\gamma_{\mu}(U)\right) \subseteq \beta_{\lambda}(V)$. As $x \in \gamma_{\mu}-c(A)$, we have $\gamma_{\mu}(U) \cap A \neq \varnothing$, and hence $\varnothing \neq f\left(\gamma_{\mu}(U) \cap A\right) \subseteq$ $\subseteq f\left(\gamma_{\mu}(U)\right) \cap f(A) \subseteq \beta_{\lambda}(V) \cap f(A)$. This shows that $y \in \beta_{\lambda}-c(f(A))$.

(ii) Let $W$ be a $\beta_{\lambda}$-open set in $(Y, \lambda)$ and $x$ any point of $f^{-1}(W)$. We have to show that $f^{-1}(W)$ is $\gamma_{\mu}$-open. There exists a $\beta$-open set $V$ containing $f(x)$ such that $\beta_{\lambda}(V) \subseteq W$. Thus by $(\gamma, \beta)$-continuity of $f$, there exists a $\mu$-open set $U$ containing $x$ such that $f\left(\gamma_{\mu}(U)\right) \subseteq \beta_{\lambda}(V)$. Thus $\gamma_{\mu}(U) \subseteq f^{-1}\left(\beta_{\lambda}(V)\right) \subseteq f^{-1}(W)$. Thus $f^{-1}(W)$ is $\gamma_{\mu}$-open.

Definition 3.13. A function $f:(X, \mu) \rightarrow(Y, \lambda)$ is said to be $(\gamma, \beta)$-closed if for any $\gamma_{\mu}$-closed set $A$ of $X$, $f(A)$ is a $\beta_{\lambda}$-closed set in $Y$.

Let $i d_{\mu}: \mu \rightarrow \mathcal{P}(X)$ be the identity operation, where $(X, \mu)$ is a GTS. We note that $i d_{\mu}$-open sets and $\mu$-open sets are identical.

Proposition 3.14. Let $f:(X, \mu) \rightarrow(Y, \lambda)$ be a $(\gamma, \beta)$-continuous function and $f$ be a $(i d, \beta)$-closed mapping. The following properties hold:

(i) For each $\gamma_{\mu} g$-closed set $A$ of $X, f(A)$ is $\beta_{\lambda} g$-closed in $Y$.

(ii) For each $\beta_{\lambda} g$-closed set $B$ of $Y, f^{-1}(B)$ is $\gamma_{\mu} g$-closed.

Proof. (i) Let $V$ be any $\beta_{\lambda}$-open set of $(Y, \lambda)$ with $f(A) \subseteq V$. Then by Theorem 3.12 (ii), $f^{-1}(V)$ is a $\gamma_{\mu}$-open set. Now as $A$ is a $\gamma_{\mu} g$-closed set and $A \subseteq f^{-1}(V)$, we have $\gamma_{\mu}-c(A) \subseteq f^{-1}(V)$, and thus $f\left(\gamma_{\mu}-c(A)\right) \subseteq V$. From the assumption and Theorem 2.15(i) it follows that, $f\left(\gamma_{\mu}-c(A)\right)$ is $\beta_{\lambda}$-closed. Thus by Remark 2.13, we have $\beta_{\lambda}-c(f(A)) \subseteq c_{\beta_{\lambda}}\left(\left(f\left(\gamma_{\mu}-c(A)\right)\right)\right)=f\left(\gamma_{\mu}-c(A)\right) \subseteq V$. This shows that $f(A)$ is $\beta_{\lambda} g$-closed in $Y$.

(ii) Let $U$ be any $\gamma_{\mu}$-open set of $(X, \mu)$ such that $f^{-1}(B)$ is contained in $U$. Let $F=\gamma_{\mu}-c\left(f^{-1}(B)\right) \cap(X \backslash U)$. Then $F$ is $\mu$-closed in $(X, \mu)$ (by Theorem 2.15(i) and Remark 2.3(a)). Since $f$ is a $(i d, \beta)$-closed function, $f(F)$ is a $\beta_{\lambda}$-closed set in $(Y, \lambda)$. Then by Proposition 3.5 and the relation $f(F) \subseteq \beta_{\lambda}-c(B) \backslash B$, it follows that $f(F)=\varnothing$ and thus $F=\varnothing$. Thus $\gamma_{\mu}-c\left(f^{-1}(B)\right) \subseteq U$ i.e., $f^{-1}(B)$ is $\gamma_{\mu} g$-closed.

Theorem 3.15. Let $f:(X, \mu) \rightarrow(Y, \lambda)$ be a $(\gamma, \beta)$-continuous and $(i d, \beta)$-closed function.

(i) If $f$ is an injective function and $(Y, \lambda)$ is a $\beta_{\lambda}-T_{1 / 2}$ space, then $(X, \mu)$ is a $\gamma_{\mu}-T_{1 / 2}$ space.

(ii) If $f$ is a surjective function and $(X, \mu)$ is a $\gamma_{\mu}-T_{1 / 2}$ space, then $(Y, \lambda)$ is a $\beta_{\lambda}-T_{1 / 2}$ space.

(iii) If $f$ is bijective, then $(X, \mu)$ is a $\gamma_{\mu}-T_{1 / 2}$ space if and only if $(Y, \lambda)$ is a $\beta_{\lambda}-T_{1 / 2}$ space. 
Proof. (i) We need only to show that every $\gamma_{\mu} g$-closed set is $\gamma_{\mu}$-closed. Let $A$ be a $\gamma_{\mu} g$-closed set of $(X, \mu)$. It then follows from Proposition 3.14(i) that $f(A)$ is $\beta_{\lambda} g$-closed and thus $f(A)$ is $\beta_{\lambda}$-closed (as $(Y, \lambda)$ is $\left.\beta_{\lambda}-T_{1 / 2}\right)$. Now by Theorem 3.12(ii), $f^{-1}(f(A))$ is $\gamma_{\mu}$-closed (as $f$ is $(\gamma, \beta)$-continuous) i.e., $A$ is $\gamma_{\mu}$-closed.

(ii) Let $B$ be a $\beta_{\lambda} g$-closed set of $(Y, \lambda)$. We have to show that $B$ is a $\beta_{\lambda}$-closed set. By Theorem 3.14(ii), $f^{-1}(B)$ is a $\gamma_{\mu} g$-closed set in $(X, \mu)$. Thus $f^{-1}(B)$ is $\gamma_{\mu}$-closed (as $(X, \mu)$ is $\left.\gamma_{\mu}-T_{1 / 2}\right)$. Thus from the assumption it follows that $B\left(=f f^{-1}(B)\right)$ is $\beta_{\lambda}$-closed in $(Y, \lambda)$. Thus it follows that $(Y, \lambda)$ is a $\beta_{\lambda}-T_{1 / 2}$ space.

(iii) The proof follows from (i) and (ii).

Theorem 3.16. Suppose that $f:(X, \mu) \rightarrow(Y, \lambda)$ is a $(\gamma, \beta)$-continuous bijection and $f^{-1}:(Y, \lambda) \rightarrow(X, \mu)$ is $(\beta, \gamma)$-continuous. Then $(X, \mu)$ is a $\gamma_{\mu}-T_{1 / 2}$ space if and only if $(Y, \lambda)$ is a $\beta_{\lambda}-T_{1 / 2}$ space.

Proof. Let $(X, \mu)$ be a $\gamma_{\mu}-T_{1 / 2}$ space. In view of Theorem 3.7 it is sufficient to show that any singleton set of $(Y, \lambda)$ is either $\beta_{\lambda}$-closed or $\beta_{\lambda}$-open. Let $\{y\}$ be any subset of $(Y, \lambda)$. Then, since $f$ is surjective, there exists $x \in X$ such that $f(x)=y$. Then by Theorem 3.7 it follows that $\{x\}$ is $\gamma_{\mu}$-closed or $\gamma_{\mu}$-open (as $(X, \mu$ ) is $\left.\gamma_{\mu}-T_{1 / 2}\right)$. Then by Theorem 3.12, $\{y\}(=f(\{x\}))$ is $\beta_{\lambda}$-closed or $\beta_{\lambda}$-open. Thus $(Y, \lambda)$ is a $\beta_{\lambda}-T_{1 / 2}$ space. The proof of the converse is similar.

Proposition 3.17. Let $f:(X, \mu) \rightarrow(Y, \lambda)$ be a $(\gamma, \beta)$-continuous injection and $(Y, \lambda)$ be a $\beta_{\lambda}-T_{2}\left(\right.$ resp. $\left.\beta_{\lambda}-T_{1}\right)$ space. Then $(X, \mu)$ is a $\gamma_{\mu}-T_{2}\left(\operatorname{resp} . \gamma_{\mu}-T_{1}\right)$ space.

Proof. Let $(Y, \lambda)$ be a $\beta_{\lambda}-T_{2}$ space. Let $x, y$ be any two points of $X$ with $x \neq y$. Then there exist $\lambda$-open sets $V$ and $W$ of $Y$ contaning $f(x)$ and $f(y)$ respectively such that $\beta_{\lambda}(V) \cap \beta_{\lambda}(W)=\varnothing$. Now by $(\gamma, \beta)$ continuity of $f$, there exist $\mu$-open sets $G$ and $H$ containing $x$ and $y$ respectively such that $f\left(\gamma_{\mu}(G)\right) \subseteq \beta_{\lambda}(V)$ and $f\left(\gamma_{\mu}(H)\right) \subseteq \beta_{\lambda}(W)$. Thus $\gamma_{\mu}(G) \cap \gamma_{\mu}(H)=\varnothing$. Thus $(X, \mu)$ is a $\gamma_{\mu}-T_{2}$ space.

The proof of the case of $\beta_{\lambda}-T_{1}$ can be done similarly.

Lemma 3.18. Let $\gamma_{\mu}: \mu \rightarrow \mathcal{P}(X)$ be a regular, $\mu$-open operation and $X \in \mu$. If $(X, \mu)$ is a $\gamma_{\mu}-T_{2}$ GTS, then $\left(X, \gamma_{\mu}\right)$ is a $T_{2}$ space.

Proof. We first note that since $\gamma_{\mu}: \mu \rightarrow \mathcal{P}(X)$ is regular and $X \in \mu$, by Theorem $2.9, \gamma_{\mu}$ is a topology on $X$. Let $x, y$ be two distinct points of $X$. Then there exist $\mu$-open sets $U$ and $V$ containing $x$ and $y$, respectively, such that $\gamma_{\mu}(U) \cap \gamma_{\mu}(V)=\varnothing$. Since $\gamma_{\mu}$ is $\mu$-open, there exist $\gamma_{\mu}$-open sets $U^{*}$ and $V^{*}$ containing $x$ and $y$, respectively, such that $U^{*} \subseteq \gamma_{\mu}(U)$ and $V^{*} \subseteq \gamma_{\mu}(V)$. Thus $U^{*} \cap V^{*}=\varnothing$ and $\left(X, \gamma_{\mu}\right)$ is a $T_{2}$ space.

Theorem 3.19. Let $\gamma_{\mu}: \mu \rightarrow \mathcal{P}(X)$ be a $\mu$-open regular operation and $\beta_{\lambda}: \lambda \rightarrow \mathcal{P}(Y)$ be a $\lambda$-open regular operation such that $X \in \mu$ and $Y \in \lambda$. If $f, g:(X, \mu) \rightarrow(Y, \lambda)$ are $(\gamma, \beta)$-continuous and $(Y, \lambda)$ is $\beta_{\lambda}-T_{2}$, then the set $A=\{x \in X: f(x)=g(x)\}$ is $\gamma_{\mu}$-closed in $(X, \mu)$.

Proof. We observe first by Lemma 3.18 that, $\gamma_{\mu}$ and $\beta_{\lambda}$ are two topologies on $X$ and $Y$, respectively. We shall now show that if $f:(X, \mu) \rightarrow(Y, \lambda)$ is $(\gamma, \beta)$-continuous, then $f:\left(X, \gamma_{\mu}\right) \rightarrow\left(Y, \beta_{\lambda}\right)$ is continuous. Let $x \in X$ and $V$ be any $\beta_{\lambda}$-open set containing $f(x)$. Then there exists a $\lambda$-open set $V^{\prime}$ such that $f(x) \in V^{\prime}$ and $\beta_{\lambda}\left(V^{\prime}\right) \subseteq V$. Since $f$ is $(\gamma, \beta)$-continuous, there exists a $\mu$-open set $W$ such that $x \in W$ and $f\left(\gamma_{\mu}(W)\right) \subseteq \beta_{\lambda}\left(V^{\prime}\right) \subseteq V$. Then by $\mu$-openness of $\gamma_{\mu}$ there exists a $\gamma_{\mu}$-open set $W^{\prime}$ containing $x$ such that $W^{\prime} \subseteq \gamma_{\mu}(W)$. Thus $f\left(W^{\prime}\right) \subseteq V$. Thus $f:\left(X, \gamma_{\mu}\right) \rightarrow\left(Y, \beta_{\lambda}\right)$ is continuous and similarly $g:\left(X, \gamma_{\mu}\right) \rightarrow\left(Y, \beta_{\lambda}\right)$ is continuous. By Lemma $3.18,\left(Y, \beta_{\lambda}\right)$ is a $T_{2}$ space. Therefore the set $A=\{x \in X: f(x)=g(x)\}$ is closed in $\left(X, \gamma_{\mu}\right)$ and hence $X \backslash A$ is $\gamma_{\mu}$-open. Thus $A$ is $\gamma_{\mu}$-closed in $(X, \mu)$.

\section{Acknowledgments}

The first author acknowledges the financial support from Department of Higher education, Science and technology and Biotechnology, Government of West Bengal, India. Also, the authors are thankful to the referee for some comments to improve the paper.

\section{References}

1 Kasahara, S. (1979). Operation-compact spaces, Math. Japon., 24, 97-105.

2 Janković, D. S. (1983). On functions with $\gamma$-closed graphs, Glasnik Mat., 18(38), 141-148.

3 Ogata, H., (1991). Operations on topological spaces and associated topology, Math. Japon., 36, $175-184$.

4 Krishnan, G. S. S., Ganster, M., \& Balachandran, K. (2007). Operation approaches on semi open sets and its application, Kochi J. Math., 2, 21-33.

5 Van An, T., Cuong, D. X., \& Maki, H. (2008). On operation-preopen sets in topological space, Sci. Math. Japon., 241-260. 
6 Császár, Á. (2002). Generalized topology, generalized continuity, Acta Math. Hungar., 96, 351-357.

7 Császár, Á. (2005). Generalized open sets in generalized topologies, Acta Math. Hungar., 106, 53-66.

8 Császár, Á. (2008). $\delta$ - and $\theta$-modifications of generalized topologies, Acta Math. Hungar., 120(3), 275-279.

9 Császár, Á. (2010). Weak structures, Acta Math. Hungar., 131, 193-195.

10 Zahran, A. M., El-Saady, K., \& Ghareeb, A. (2012). Modification of weak structures via hereditary classes, Applied Mathematics Letters, 25(5), 869-872.

11 Zahran, A. M., Musa, A. K., \& Ghareeb. A. (2015). Generalized closed sets and some separation axioms on weak structure Hacettepe Journal of Math. and Stat., 44(3), 669-677.

12 Ghareeb, A., \& Khalaf, M. M. (2015). On weak structures Analele Univ. Oradea Fasc. Mat., XXII(1), 129-134.

13 Ghareeb, A., \& Güldürdek, A. (2015). On modification of weak structures via hereditary classes, Bol. Soc. Paran. Mat., 35(1), 229-235.

14 Roy, B. (2010). On generalized $R_{0}$ and $R_{1}$ spaces, Acta Math. Hungar., 127, 291-300.

15 Roy, B. (2018). Applications on operations on minimal generalized open sets, Afrika Matematika, 29, 1097-1104.

\author{
Б. Рой${ }^{1}$, Т. Нуари ${ }^{2}$ \\ ${ }^{1}$ Әйелдер христиан колледжі, Калъкутта, Үндістан; \\ ${ }^{2}$ Яиусиро, ЖКапония
}

\title{
Жалпыланған топологиялық кеңістіктерге операцияларды қолдану
}

\begin{abstract}
Мақалада $\gamma_{\mu}$ - ашық жиындар және $\gamma_{\mu}$-GTS-тегі жабық жиындар $(X, \mu)$, мұнда $\gamma_{\mu}-\mu$-дан $\mathcal{P}(X)$-ға операция зерттелген. Жалпы, $\gamma_{\mu}$ - ашық жиындар жиынтығы $\mu$-ашық жиындар жиынтығынан аз. Сонымен қатар, авторлар екі жиын бірдей болатынын анықтаған. Мұндай жиындардың кейбір қасиеттері талқыланды. Сондай-ақ, жабу түрінің кейбір операторлары анықталып, олардың қасиеттері анықталды. GTS $(X, \mu)$-да ұқсас жабу операторларының түрлері арасында байланыс орнатылған. Белгілі бір тұйықталу түрінің операторы Куратовскийдің тұйықталу операторы болып табылатын шарт беріледі. Сондай-ақ, $\gamma_{\mu}$ деп аталатын жабық жиындардың жалпыланған түрі анықталғанжалпыланған жабық жиын, осы жаңадан анықталған жабу операторының көмегімен және осындай жиындардың кейбір негізгі қасиеттері талқыланған. Қосымша ретінде бөлімнің әлсіз аксиомалары енгізіліп, олардың кейбір қасиеттері талқыланды. Соңында осындай жалпыланған ұғымдарды сақтаудың кейбір теоремалары көрсетілген.
\end{abstract}

Kiлm сөздер: операция, $\mu$ - ашық жиын, $\gamma_{\mu}$ - ашық жиын, $\gamma_{\mu} g-$ жабық жиын.

\author{
Б. Рой${ }^{1}$, Т. Нуари ${ }^{2}$ \\ ${ }^{1}$ Женский христианский колледж, Калькутта, Индия; \\ ${ }^{2}$ Яиусиро, Япония
}

\section{Приложения операций над обобщенными топологическими пространствами}

\begin{abstract}
В статье изучены $\gamma_{\mu}$-открытые и $\gamma_{\mu}$-замкнутые множества в $\operatorname{GTS}(X, \mu)$, где $\gamma_{\mu}$ - операция из $\mu$ в $\mathcal{P}(X)$. В общем случае набор $\gamma_{\mu}$-открытых множеств меньше, чем набор $\mu$-открытых множеств. Кроме того, авторами установлено условие, при котором оба множества являются одинаковыми. Обсуждены и некоторые свойства таких множеств. Определены некоторые операторы типа замыкания и их свойства. Установлена связь между аналогичными типами операторов замыкания на GTS $(X, \mu)$. Дано
\end{abstract}


условие, при котором по-новому определенный оператор типа замыкания является оператором замыкания Куратовского. Выявлен обобщенный тип замкнутых множеств, названный $\gamma_{\mu}$-обобщенным замкнутым множеством, с помощью этого вновь определенного оператора замыкания и обсуждены некоторые основные свойства таких множеств. В качестве приложения авторами введены несколько слабых аксиом отделения и определены некоторые их свойства. Таким образом, показаны некоторые теоремы сохранения таких обобщенных понятий.

Ключевые слова: операция, $\mu$-открытое множество, $\gamma_{\mu}$-открытое множество, $\gamma_{\mu} g$-замкнутое множество.

\section{References}

1 Kasahara, S. (1979). Operation-compact spaces, Math. Japon., 24(1979), 97-105.

2 Janković, D. S. (1983). On functions with $\gamma$-closed graphs, Glasnik Mat., 18(38), 141-148.

3 Ogata, H.(1991). Operations on topological spaces and associated topology, Math. Japon., 36, $175-184$.

4 Krishnan, G. S. S. Ganster, M. \& Balachandran, K.(2007). Operation approaches on semi open sets and its application, Kochi J. Math., 2, 21-33.

5 Van An, T. Cuong D. X. \& Maki, H. (2008). On operation-preopen sets in topological space, Sci. Math. Japon., 241-260.

6 Császár, Á. (2002). Generalized topology, generalized continuity, Acta Math. Hungar., 96, 351-357.

7 Császár, Á.(2005). Generalized open sets in generalized topologies, Acta Math. Hungar., 106, 53-66.

8 Császár, Á.(2008). $\delta$ - and $\theta$-modifications of generalized topologies, Acta Math. Hungar., 120(3), $275-279$.

9 Császár, Á.(2010). Weak structures, Acta Math. Hungar., 131, 193-195.

10 Zahran A. M. El-Saady K. \& Ghareeb, A. (2012). Modification of weak structures via hereditary classes, Applied Mathematics Letters, 25(5), 869-872.

11 Zahran, A. M. Musa, A. K \& Ghareeb A. (2015). Generalized closed sets and some separation axioms on weak structure Hacettepe Journal of Math. and Stat., 44(3), 669 - 677.

12 Ghareeb, A. \& Khalaf M. M. (2015). On weak structures Analele Univ. Oradea Fasc. Mat., Tom XXII(1), $129-134$.

13 Ghareeb, A. \& Güldürdek, A. (2015). On modification of weak structures via hereditary classes, Bol. Soc. Paran. Mat., 35(1), 229-235.

14 Roy, B. (2010). On generalized $R_{0}$ and $R_{1}$ spaces, Acta Math. Hungar., (127), 291-300.

15 Roy, B. (2018). Applications on operations on minimal generalized open sets, Afrika Matematika, 29, 1097-1104. 


\author{
S. Saghali ${ }^{1}$, F.D. Saei ${ }^{1, *}$, M. Javidi², M.J. $\operatorname{Rad}^{1}$ \\ ${ }^{1}$ Islamic Azad University Tabriz Branch, Tabriz, Iran; \\ ${ }^{2}$ University of Tabriz, Tabriz, Iran \\ (E-mail: stu.s.saghali@iaut.ac.ir,dastmalchi@iaut.ac.ir,mo-javidi@tabriz.ac.ir,Jahangiri@iaut.ac.ir)
}

\title{
Analytical solution of a fractional differential equation in the theory of viscoelastic fluids
}

\begin{abstract}
The aim of this paper is to present analytical solutions of fractional delay differential equations (FDDEs) of an incompressible generalized Oldroyd-B fluid with fractional derivatives of Caputo type. Using a modification of the method of separation of variables the main equation with non-homogeneous boundary conditions is transformed into an equation with homogeneous boundary conditions, and the resulting solutions are then expressed in terms of Green functions via Laplace transforms. This results presented in two condition, in first step when $0 \leq \alpha, \beta \leq \frac{1}{2}$ and in the second step we considered $\frac{1}{2} \leq \alpha, \beta \leq 1$, for each step 1,2 for the unsteady flows of a generalized Oldroyd-B fluid, including a flow with a moving plate, are considered via examples.
\end{abstract}

Keywords: Oldroyd-B fluid, fractional-order partial differential equations, analytical solutions, Delay differential equation, modified separation of variables method, Caputo fractional derivatives.

\section{Introduction}

Many real-world processes can be cast generally in the form of fractional differential systems with integer order (i.e., ordinary differential equations and systems) but there is a growing number of researchers that believe that fractional-differential equations can describe and model and complex physical processes more accurately than the corresponding ordinary differential equations. So, in recent decades the search for analytical and numerical solutions to fractional differential equations has been of considerable interest [1-4]. Fractional differential equations can be applied to the dynamic modeling of non-Newtonian fluids: for example, in the modeling of melting plastics and in the study of emulsion plastics or soft tissue. Practically speaking, there are few Newtonian fluids in reality, so most fluids are of the non-Newtonian type, which means there is no linear relationship between the stress tensor and the deformation tensor [5].

Viscoelastic fluids form an important class of non-Newtonian fluids, which exhibit both elastic and viscous properties. Among them the so-called Oldroyd-B fluid can be used to describe the response of fluids that have a small memory. This means that whenever they flow, these fluids will spend less time to find the first state and stability [6-7]. Due to the wide range of applications of these fluids, considerable attention has been paid to the prediction of the behavior of non-Newtonian fluids. Structural equations that are presented in a constitutive rheological fashion have a fractional calculation, so they are very effective for working with viscoelastic properties [8-9]. The viscoelastic fluid equations in fractional models are obtained by replacing ordinary derivatives with one of many possible definitions of fractional derivatives in the defining equations. In the study of fluids we deal with a phenomenon called delay, which is due to the distance between the sensor and the source of changes arising from e.g., plumbing, measurement slowness, or complex dynamics. Different methods for finding analytical solutions of these type of equations are proposed: an analytical solution for unsteady helical flows is presented by Tong et al in [10]. In Haitao and Mingyu [11] there is a discussion of an Oldroyd-B fluid between two parallel plates. In addition, Fetecau [12-13] developed a generalization of the flow of viscoelastic fluids between two-sided walls. Then Shah [14], Qi [15], Zheng et al [16] and Hayat [17] discussed the generalized flow of an Oldroyd-B fluid under varying conditions. In closing this brief review we mention that Javidi and Heris [18] gave analytical solutions of various forms of such delay equations.

Many events in the natural world can be modeled to form of fractional delay differential equations (FDDEs). FDDEs have important applications in many fields for example technology, economics, biology, medical science,

\footnotetext{
${ }^{*}$ Corresponding author.

E-mail:dastmalchi@iaut.ac.ir
} 
physics and finance [19]. Some numerical methods for FDDEs are introduced in [20-23] and etc. Heris and Javidi [24] proposed a numerical method based on fractional backward differential formulas (FBDF) for solving fractional delay differential equations. Also they found the Green's functions for this equation corresponding to periodic/anti-periodic conditions in terms of the functions of Mittag Leffler type.

In this paper we present analytical solutions for unsteady flows of a generalized Oldroyd-B fluid with constant delay time using Riemann-Liouville fractional derivatives as the defining derivatives. A new separation of variables method [25] and use of Laplace transforms for the Riemann-Liouville fractional derivative are adapted to solve the new governing equation for fractional differential equations with constant delay when applied to viscoelastic fluids.

The paper is structured as follows: in section 2 we recall some basic definitions of fractional calculus; in section 3 we give the derivation of the governing equation; section 4 deals with the method of separation of variables, the Laplace transformation applied to fractional derivatives in two steps $0 \leq \alpha, \beta \leq \frac{1}{2}$ and $\frac{1}{2} \leq \alpha$, $\beta \leq 1$, and the method of solution for each two steps separatively. Finally, in section 5 we give the examples dealing with varying initial conditions by considering two condition for $\alpha$ and $\beta$.

\section{Preliminaries}

In this section we will introduce some of the fundamental definitions.

Defenition 1.1 ([1]). Euler's gamma function is defined by the integral

$$
\Gamma(z)=\int_{0}^{\infty} e^{-t} t^{z-1} d t, \operatorname{Re}(z)>0 .
$$

$C(J, R)$ denotes the Banach space of all continuous functions from $J=[0, T]$ into $R$ with the norm

$$
\|u\|_{\infty}=\sup \{|u(t)|: t \in J\}, \quad T>0 .
$$

$C^{n}(J, R)$ denotes the class of all real valued functions defined on $J=[0, T], T>0$ which have continuous $n$-th order derivatives.

Defenition 1.2 [4]. The fractional integral of order $\alpha>0$ of the function $f \in C(J, R)$ is defined as

$$
I^{\alpha} f(t)=\frac{1}{\Gamma(\alpha)} \int_{0}^{t} \frac{f(s)}{(t-s)^{1-\alpha}} d s, \quad 0<t<T .
$$

Defenition 1.3 [4]. The Riemann-Liouville fractional derivative of order $\alpha>0$ of the function $f \in C(J, R)$ is defined as

$$
{ }^{R L} D^{\alpha} f(t)=\left\{\begin{array}{l}
D^{n} I^{n-\alpha} f(t)=\frac{1}{\Gamma(n-\alpha)}\left(\frac{d^{n}}{d t^{n}}\right) \int_{0}^{t} \frac{f(s)}{(t-s)^{\alpha-n+1}} d s, \\
n-1<\alpha<n, n \in N, \\
f^{(n)}(t), \quad \alpha=n .
\end{array}\right.
$$

Defenition 1.4 [4]. The Caputo fractional derivative of order $\alpha>0$ of the function $f \in C^{n}(J, R)$ is defined as

$$
{ }^{C} D^{\alpha} f(t)=\left\{\begin{array}{rr}
I^{n-\alpha} D^{n} f(t)=\frac{1}{\Gamma(n-\alpha)} \int_{0}^{t} \frac{f^{(n)}(s)}{(t-s)^{\alpha-n+1}} d s, \\
n-1<\alpha<n, n \in N, \\
f^{(n)}(t), & \alpha=n .
\end{array}\right.
$$

Defenition 1.5 [4]. Mittag-leffler functions are defined by

$$
E_{\alpha, \beta}(x)=\sum_{k=0}^{\infty} \frac{x^{k}}{\Gamma(\alpha k+\beta)}, x, \beta \in C, \operatorname{Re}(\alpha)>0, E_{\alpha}(x)=E_{\alpha, 1} .
$$

Defenition 1.6 [22]. The generalized delay exponential function (of Mittag-Leffler type) is given by

$$
G_{\alpha, \beta}^{\lambda, \tau}(t)=\sum_{j=0}^{\infty}\left(\begin{array}{l}
j+m \\
j
\end{array}\right) \frac{\lambda^{j}(t-(m+j) \tau)^{\alpha(m+j)+\beta-1}}{\Gamma(\alpha(m+j)+\beta)} H(t-(m+j) \tau), t>0,
$$


where $\lambda \in C, \alpha, \beta, \tau \in R$ and $m \in Z$ and $H(z)$ is the Heaviside step function. If $\lambda \in C, \alpha, \beta, \tau \in R$ and $m \in Z$ then laplace transform of $G_{\alpha, \beta}^{\lambda, \tau, m}(t)$ is:

$$
L\left(G_{\alpha, \beta}^{\lambda, \tau, m}(t)\right)(s)=\frac{s^{\alpha-\beta} \exp \{-m s \tau\}}{\left(s^{\alpha}-\lambda \exp \{-s \tau\}\right)^{m+1}}, \quad s>0 .
$$

\section{Governing equations}

The fundamental equations governing the unsteady motion of an incompressible fluid are

$$
\begin{gathered}
\operatorname{div} V=0, \\
\rho \frac{d V}{d t}=-\nabla p+\operatorname{div} S+F_{b} .
\end{gathered}
$$

The constitutive equation for a generalized Oldroyd-B fluid is given by [15-16],

$$
\left(1+\lambda^{\alpha} \frac{D^{\alpha}}{D t^{\alpha}}\right) S=\mu\left(1+\lambda^{\beta} \frac{D^{\beta}}{D t^{\beta}}\right) A_{1},
$$

where $V=(u, v, w)$ is the fluid velocity, $S=\left(S_{i, j}\right)$ is the extra-stress tensor, $A_{1}=(\nabla V)+(\nabla V)^{T}$ present the first Rivlin-Ericksen tensor, $\nabla$ is the gradient operator, and $p$ is the pressure. Here $F_{b}=\left(F_{b x}, F_{b y}, F_{b z}\right)$ is the body force, $\rho, \mu$ are the density and the dynamic viscosity coefficient of the fluid respectively, $\lambda_{\alpha}$ and $\lambda_{\beta}$ are the material constants that represent the relaxation time and retardation time, respectively, and $\alpha, \beta$ denote the orders of the fractional derivatives, i.e., real numbers that satisfy $0 \leq \alpha, \beta \leq 1$. Furthermore, $\frac{D^{\alpha}}{D t^{\alpha}}$ and $\frac{D^{\beta}}{D t^{\beta}}$ are fractional material derivatives that can be expressed as

$$
\begin{aligned}
& \frac{D^{\alpha} S}{D t^{\alpha}}=D_{t}^{\alpha} S+(V . \nabla) S-(\nabla \cdot V) S-S(\nabla V)^{T}, \\
& \frac{D^{\beta} S}{D t^{\beta}}=D_{t}^{\beta} S+(V . \nabla) S-(\nabla \cdot V) S-S(\nabla V)^{T} .
\end{aligned}
$$

In Eq. (3), (5), the fractional derivative operator $D^{\alpha}$ is taken in the Caputo.

We consider unidirectional flow, that is the case where the velocity and the stress take the form

$$
V=u(y, t) i, \quad S=S(y, t),
$$

where $i$ is the unit vector along the $\mathrm{x}$-direction of the Cartesian coordinate system $\mathrm{x}, \mathrm{y}$ and $\mathrm{z}$. Using Eq. (6) below, the continuity Eq.(1) is satisfied automatically while Eq. (4), bearing in mind the initial condition $S(y, 0)=0$, leads to the following relationships for the constitutive equation

$$
\begin{array}{r}
S_{x z}=S_{z y}=S_{y z}=S_{z z}=S_{y y}=0, \quad S_{y x}=S_{x y}, S_{z x}=S_{x z}, \\
\left(1+\lambda_{\alpha} D_{t}^{\alpha}\right) S_{x y}=\mu\left(1+\lambda_{\beta} D_{t}^{\beta}\right) \frac{\partial u}{\partial y}, \\
\left(1+\lambda_{\alpha} D_{t}^{\alpha}\right) S_{x x}-2 \lambda_{\alpha} S_{x y} \frac{\partial u}{\partial y}=-2 \mu \lambda_{\beta}\left(\frac{\partial u}{\partial y}\right)^{2} .
\end{array}
$$

Substituting Eqs.(6) into momentum equation (2), we have the following equation in x-direction:

$$
\left(1+\lambda_{\alpha} D_{t}^{\alpha}\right) \frac{\partial u}{\partial t}=v\left(1+\lambda_{\beta} D_{t}^{\beta}\right) \frac{\partial^{2} u}{\partial y^{2}}+\frac{1}{\rho}\left(1+\lambda_{\alpha} D_{t}^{\alpha}\right)\left(F_{b x}-\frac{\partial p}{\partial x}\right),
$$

where $\nu=\frac{\mu}{\rho}$ is the kinematic viscosity coefficient of fluid.

The constitutive equation of a generalized Burgers fluid is

$$
\left(1+\lambda_{\alpha} \frac{D^{\alpha}}{D t^{\alpha}}+\theta \frac{D^{2 \alpha}}{D t^{2 \alpha}}\right) S=\mu\left(1+\lambda_{\beta} \frac{D^{\beta}}{D t^{\beta}}\right) A_{1}, \quad(0<\alpha, \beta \leq 1),
$$

where $\theta$ is the material constant. 
Combining the constitutive equation (8) with the equation (2) we get the following fractional Burgers fluid model

$$
\left(1+\lambda_{\alpha} D_{t}^{\alpha}+\theta D_{t}^{2 \alpha}\right) \frac{\partial u}{\partial t}=v\left(1+\lambda_{\beta} D_{t}^{\beta}\right) \frac{\partial^{2} u}{\partial y^{2}}+\frac{1}{\rho}\left(1+\lambda_{\alpha} D_{t}^{\alpha}+\theta D_{t}^{2 \alpha}\right)\left(F_{b x}-\frac{\partial p}{\partial x}\right),
$$

where $\nu=\mu / \rho$. Eqs. (7)and (9) have the following form:

$$
\begin{gathered}
a_{0} D_{t}^{2 \alpha+1} u(y, t)+a_{1} D_{t}^{\alpha+1} u(y, t)+a_{2} D_{t}^{2 \alpha} u(y, t)+a_{3} D_{t}{ }^{1} u(y, t) \\
+a_{4} D_{t}^{\alpha} u(y, t)+a_{5} u(y, t)=b_{1} D_{t}^{\beta} \frac{\partial^{2} u(y, t)}{\partial y^{2}}+b_{2} \frac{\partial^{2} u(y, t)}{\partial y^{2}}+\bar{f}(y, t),
\end{gathered}
$$

the delay form of Eqs (10) is

$$
\begin{gathered}
a_{0} D_{t}^{2 \alpha+1} u(y, t)+a_{1} D_{t}^{\alpha+1} u(y, t)+a_{2} D_{t}^{2 \alpha} u(y, t)+a_{3} D_{t}{ }^{1} u(y, t) \\
+a_{4} D_{t}^{\alpha} u(y, t)+a_{5} u(y, t-\tau)=b_{1} D_{t}^{\beta} \frac{\partial^{2} u(y, t)}{\partial y^{2}}+b_{2} \frac{\partial^{2} u(y, t)}{\partial y^{2}}+\bar{f}(y, t) .
\end{gathered}
$$

The associated initial and boundary conditions are as follows:

$$
\begin{gathered}
u(y, t)=\psi_{1}(y, t), \quad u(0, t)=\varphi_{1}(t),-\tau \leq t \leq 0, \\
u_{t}(y, t)=\psi_{2}(y, t), \quad u(L, t)=\varphi_{1}(t), \quad 0<\alpha, \beta<1 .
\end{gathered}
$$

A method of separation of variables

At first, the problem involves non-homogeneous boundary conditions. We want to transform it into a problem with homogeneous boundary conditions. So, consider

$$
u(y, t)=W(y, t)+V(y, t)
$$

where

$$
V(y, t)=\left(1-\frac{y}{L}\right) \varphi_{1}(t)+\frac{y}{L} \varphi_{2}(t),
$$

which satisfies the boundary conditions

$$
V(0, t)=\varphi_{1}(t), V(L, t)=\varphi_{2}(t) .
$$

Using Eqs.(11) and Eqs.(12) along with the associated initial and boundary conditions above, we have

$$
\begin{aligned}
& W(y, t)+\left(1-\frac{y}{L}\right) \varphi_{1}(t)+\frac{y}{L} \varphi_{2}(t)=\psi_{1}(y, t), \quad-\tau \leq t \leq 0, \\
& W_{t}(y, t)+\left(1-\frac{y}{L}\right) \varphi_{1}^{\prime}(t)+\frac{y}{L} \varphi^{\prime}{ }_{2}(t)=\psi_{2}(y, t), \\
& W(L, t)+V(L, t)=\varphi_{2}(t), \\
& W(L, t)+V(L, t)=\varphi_{2}(t) \\
& W(y, t)=\psi_{1}(y, t)-\left(1-\frac{y}{L}\right) \varphi_{1}(t)-\frac{y}{L} \varphi_{2}(t)=\overline{\psi_{1}}(y, t), \\
& W_{t}(y, t)=\psi_{1}(y, t)-\left(1-\frac{y}{L}\right) \varphi_{1}^{\prime}(t)-\frac{y}{L} \varphi^{\prime}{ }_{2}(t)=\overline{\psi_{2}}(y, t) .
\end{aligned}
$$

Now main problem is solving

$$
\begin{gathered}
a_{0} D_{t}{ }^{2 \alpha+1} W(y, t)+a_{1} D_{t}{ }^{\alpha+1} W(y, t)+a_{2} D_{t}{ }^{2 \alpha} W(y, t)+a_{3} D_{t}{ }^{1} W(y, t)+ \\
\quad+a_{4} D_{t}{ }^{\alpha} W(y, t)+a_{5} W(y, t-\tau)-b_{1} D_{t}^{\beta} \frac{\partial^{2} w(y, t)}{\partial y^{2}}-b_{2} \frac{\partial^{2} w(y, t)}{\partial y^{2}}= \\
=-a_{0} D_{t}{ }^{2 \alpha+1} V(y, t)-a_{1} D_{t}^{\alpha+1} V(y, t)-a_{2} D_{t}{ }^{2 \alpha} V(y, t)-a_{3} D_{t}{ }^{1} V(y, t),
\end{gathered}
$$

where the initial condition is

$$
\sum_{n=1}^{\infty} B_{n}(0) \sin \frac{n \pi y}{L}=\sum_{n=1}^{\infty} d_{n}^{(1)}(0) \sin \frac{n \pi y}{L}-\sum_{n=1}^{\infty} \frac{2}{n \pi}\left[\varphi_{1}(0)-(-1)^{n} \varphi_{2}(0)\right] \sin \frac{n \pi y}{L},
$$




$$
\sum_{n=1}^{\infty} B^{\prime}{ }_{n}(0) \sin \frac{n \pi y}{L}=\sum_{n=1}^{\infty} d_{n}^{(2)}(0) \sin \frac{n \pi y}{L}-\sum_{n=1}^{\infty} \frac{2}{n \pi}\left[\varphi^{\prime}{ }_{1}(0)-(-1)^{n} \varphi_{2}^{\prime}(0)\right] \sin \frac{n \pi y}{L}
$$

and

$$
d_{n}^{(i)}=\frac{2}{L} \int_{0}^{L} \bar{\psi}_{i}(y, 0) \sin \frac{n \pi y}{L} d y, \quad i=1,2 .
$$

Let

$$
\begin{gathered}
W(y, t)=\sum_{n=1}^{\infty} B_{n}(t) \sin \frac{n \pi y}{L} \\
\overline{\psi_{i}}(y)=\sum_{n=1}^{\infty} d_{n}^{(i)} \sin \frac{n \pi y}{L} \quad(i=1,2, \ldots, m) .
\end{gathered}
$$

Then, we have

$$
\begin{gathered}
a_{0} D_{t}{ }^{2 \alpha+1} \sum_{n=1}^{\infty} B_{n}(t) \sin \frac{n \pi y}{L}+a_{1} D_{t}{ }^{\alpha+1} \sum_{n=1}^{\infty} B_{n}(t) \sin \frac{n \pi y}{L}+a_{2} D_{t}^{2 \alpha} \sum_{n=1}^{\infty} B_{n}(t) \sin \frac{n \pi y}{L}+ \\
+a_{3} D_{t}{ }^{1} \sum_{n=1}^{\infty} B_{n}(t) \sin \frac{n \pi y}{L}+a_{4} D_{t}{ }^{\alpha} \sum_{n=1}^{\infty} B_{n}(t) \sin \frac{n \pi y}{L}+a_{5} \sum_{n=1}^{\infty} B_{n}(t-\tau) \sin \frac{n \pi y}{L}- \\
-b_{1}\left(\frac{n \pi}{L}\right)^{2} D_{t}^{\beta} \sum_{n=1}^{\infty} B_{n}(t) \sin \frac{n \pi y}{L}-b_{2}\left(\frac{n \pi}{L}\right)^{2} \sum_{n=1}^{\infty} B_{n}(t) \sin \frac{n \pi y}{L}= \\
=-a_{0} \frac{2}{n \pi} D_{t}{ }^{2 \alpha+1} \sum_{n=1}^{\infty}\left[\varphi_{1}(t)-(-1)^{n} \varphi_{2}(t)\right] \sin \frac{n \pi y}{L}-a_{1} \frac{2}{n \pi} D_{t}^{\alpha+1} \sum_{n=1}^{\infty}\left[\varphi_{1}(t)-(-1)^{n} \varphi_{2}(t)\right] \sin \frac{n \pi y}{L}- \\
-a_{2} \frac{2}{n \pi} D_{t}{ }^{2 \alpha} \sum_{n=1}^{\infty}\left[\varphi_{1}(t)-(-1)^{n} \varphi_{2}(t)\right] \sin \frac{n \pi y}{L}-a_{3} \frac{2}{n \pi} D_{t}{ }^{1} \sum_{n=1}^{\infty}\left[\varphi_{1}(t)-(-1)^{n} \varphi_{2}(t)\right] \sin \frac{n \pi y}{L}- \\
-a_{4} \frac{2}{n \pi} D_{t}{ }^{\alpha} \sum_{n=1}^{\infty}\left[\varphi_{1}(t)-(-1)^{n} \varphi_{2}(t)\right] \sin \frac{n \pi y}{L}-a_{5} \frac{2}{n \pi} \sum_{n=1}^{\infty}\left[\varphi_{1}(t-\tau)-(-1)^{n} \varphi_{2}(t-\tau)\right] \sin \frac{n \pi y}{L}+ \\
+\sum_{n=1}^{\infty} f_{n}(t) \sin \frac{n \pi y}{L} .
\end{gathered}
$$

Equating coefficients leads to

$$
\begin{gathered}
a_{0} D_{t}{ }^{2 \alpha+1} B_{n}(t)+a_{1} D_{t}^{\alpha+1} B_{n}(t)+a_{2} D_{t}{ }^{2 \alpha} B_{n}(t)+a_{3} D_{t}{ }^{1} B_{n}(t)+ \\
+a_{4} D_{t}{ }^{\alpha} B_{n}(t)+a_{5} B_{n}(t-\tau)-b_{1}\left(\frac{n \pi}{L}\right)^{2} D_{t}^{\beta} B_{n}(t)-b_{2}\left(\frac{n \pi}{L}\right)^{2} B_{n}(t)= \\
=-a_{0} \frac{2}{n \pi} D_{t}{ }^{2 \alpha+1}\left[\varphi_{1}(t)-(-1)^{n} \varphi_{2}(t)\right]-a_{1} \frac{2}{n \pi} D_{t}^{\alpha+1}\left[\varphi_{1}(t)-(-1)^{n} \varphi_{2}(t)\right]- \\
-a_{2} \frac{2}{n \pi} D_{t}{ }^{2 \alpha}\left[\varphi_{1}(t)-(-1)^{n} \varphi_{2}(t)\right]-a_{3} \frac{2}{n \pi} D_{t}{ }^{1}\left[\varphi_{1}(t)-(-1)^{n} \varphi_{2}(t)\right]- \\
-a_{4} \frac{2}{n \pi} D_{t}^{\alpha}\left[\varphi_{1}(t)-(-1)^{n} \varphi_{2}(t)\right]-a_{5} \frac{2}{n \pi}\left[\varphi_{1}(t-\tau)-(-1)^{n} \varphi_{2}(t-\tau)\right]+f_{n}(t),
\end{gathered}
$$

with the boundary conditions

$$
\begin{aligned}
B_{n}(0) & =d_{n}^{(1)}(0)-\frac{2}{n \pi} \varphi_{1}(0)+(-1)^{n} \frac{2}{n \pi} \varphi_{2}(0), \\
B_{n}^{\prime}(0) & =d_{n}^{(2)}(0)-\frac{2}{n \pi} \varphi_{1}^{\prime}(0)+(-1)^{n} \frac{2}{n \pi} \varphi_{2}^{\prime}(0) .
\end{aligned}
$$

In this part we divide the main problem in two part 


$$
3.1\left(0 \leq \alpha, \beta \leq \frac{1}{2}\right)
$$

when $\frac{1}{2} \leq \alpha, \beta \leq 1$ and applying the Laplace transform with respect to $\mathrm{t}$ defined by

$$
\bar{B}_{n}(s)=\int_{0}^{\infty} e^{-s t} B_{n}(t) d t
$$

In Eq.(13), we obtain

$$
\begin{gathered}
a_{0} s^{2 \alpha+1} \bar{B}_{n}(s)-a_{0} s^{2 \alpha} B_{n}(0)+a_{1} s^{\alpha+1} \bar{B}_{n}(s)-a_{1} s^{\alpha} B_{n}(0)+a_{2} s^{2 \alpha} \bar{B}_{n}(s)-a_{2} s^{2 \alpha-1} B_{n}(0)+ \\
\left.+a_{3} s \bar{B}_{n}(s)-a_{3} B_{n}(0)+a_{4} s^{\alpha} \bar{B}_{n}(s)-a_{4} s^{\alpha-1} B_{n}(0)+a_{5} e^{-s \tau} e^{-s p} B_{n}(p) d p\right]- \\
-a_{5} e^{-s \tau} \bar{B}_{n}(s)-b_{1}\left(\frac{n \pi}{L}\right)^{2} s^{\beta} \bar{B}_{n}(s)+b_{1}\left(\frac{n \pi}{L}\right)^{2} s^{\beta-1} B_{n}(0)-b_{2}\left(\frac{n \pi}{L}\right)^{2} \bar{B}_{n}(s)= \\
=-a_{0} \frac{2}{n \pi} s^{2 \alpha+1}\left[\overline{\varphi_{1}}(s)-(-1)^{n} \overline{\varphi_{2}}(s)\right]+a_{0} \frac{2}{n \pi} s^{2 \alpha}\left[d_{n}^{(1)}(0)-B_{n}(0)\right]- \\
-a_{1} \frac{2}{n \pi} s^{\alpha+1}\left[\overline{\varphi_{1}}(s)-(-1)^{n} \overline{\varphi_{2}}(s)\right]+a_{1} \frac{2}{n \pi} s^{\alpha}\left[d_{n}^{(1)}(0)-B_{n}(0)\right]- \\
-a_{2} \frac{2}{n \pi} s^{2 \alpha}\left[\overline{\varphi_{1}}(s)-(-1)^{n} \overline{\varphi_{2}}(s)\right]+a_{2} \frac{2}{n \pi} s^{2 \alpha-1}\left[d_{n}^{(1)}(0)-B_{n}(0)\right]- \\
-a_{3} \frac{2}{n \pi} s\left[\overline{\varphi_{1}}(s)-(-1)^{n} \overline{\varphi_{2}}(s)\right]+a_{3} \frac{2}{n \pi}\left[d_{n}^{(1)}(0)-B_{n}(0)\right]- \\
-a_{4} \frac{2}{n \pi} s^{\alpha}\left[\overline{\varphi_{1}}(s)-(-1)^{n} \overline{\varphi_{2}}(s)\right]+a_{4} \frac{2}{n \pi} s^{\alpha-1}\left[d_{n}^{(1)}(0)-B_{n}(0)\right]-a_{5} \frac{2}{n \pi} e^{-s \tau}\left[\overline{\varphi_{1}}(s)-(-1)^{n} \overline{\varphi_{2}}(s)\right]+ \\
+a_{5} \frac{2}{n \pi} e^{-s \tau}\left[\int_{-\tau}^{0} e^{-s p}\left[\varphi_{1}(p)-(-1)^{n} \varphi_{2}(p)\right] d p\right]+F_{n}(s) . \\
0
\end{gathered}
$$

By assumption $H(S)=\int_{-\tau}^{0} e^{-s p}\left[\varphi_{1}(p)-(-1)^{n} \varphi_{2}(p)\right] d p, \quad G(s)=\int_{-\tau}^{0} e^{-s p} B_{n}(p) d p$ and $k_{n}=\frac{n \pi}{L}$, so we can write

$$
\begin{gathered}
\bar{B}_{n}(s)=\frac{B_{n}(0)\left[a_{0} s^{2 \alpha}+a_{1} s^{\alpha}+a_{2} s^{2 \alpha-1}+a_{3}+a_{4} s^{\alpha-1}-b_{1} k_{n}{ }^{2} s^{\beta-1}\right]}{a_{0} s^{2 \alpha+1}+a_{1} s^{\alpha+1}+a_{2} s^{2 \alpha}+a_{3} s+a_{4} s^{\alpha}-a_{5} e^{-s \tau}-b_{1} k_{n}{ }^{2} s^{\beta}-b_{2} k_{n}{ }^{2}}+ \\
+\frac{-\frac{2}{k_{n} L}\left[\overline{\varphi_{1}}(s)-(-1)^{n} \overline{\varphi_{2}}(s)\right]\left[a_{0} s^{2 \alpha+1}+a_{1} s^{\alpha+1}+a_{2} s^{2 \alpha}+a_{3} s+a_{4} s^{\alpha}+a_{5} e^{-s \tau}\right]}{a_{0} s^{2 \alpha+1}+a_{1} s^{\alpha+1}+a_{2} s^{2 \alpha}+a_{3} s+a_{4} s^{\alpha}-a_{5} e^{-s \tau}-b_{1} k_{n}{ }^{2} s^{\beta}-b_{2} k_{n}{ }^{2}}+ \\
+\frac{\frac{2}{k_{n} L}\left[d_{n}^{(1)}(0)-B_{n}(0)\right]\left\{a_{0} s^{2 \alpha}+a_{1} s^{\alpha}+a_{2} s^{2 \alpha-1}+a_{3}+a_{4} s^{\alpha-1}\right\}}{a_{0} s^{2 \alpha+1}+a_{1} s^{\alpha+1}+a_{2} s^{2 \alpha}+a_{3} s+a_{4} s^{\alpha}-a_{5} e^{-s \tau}-b_{1} k_{n}{ }^{2} s^{\beta}-b_{2} k_{n}{ }^{2}}+ \\
+\frac{-a_{5} G(s) e^{-s \tau}+a_{5} \frac{2}{k_{n} L} e^{-s \tau} H(S)+F_{n}(s)}{a_{0} s^{2 \alpha+1}+a_{1} s^{\alpha+1}+a_{2} s^{2 \alpha}+a_{3} s+a_{4} s^{\alpha}-a_{5} e^{-s \tau}-b_{1} k_{n}{ }^{2} s^{\beta}-b_{2} k_{n}{ }^{2}} .
\end{gathered}
$$

Using Eq.(14) we rewrite Eq.(13) as

$$
\bar{B}_{n}(s)=e^{s m \tau} \sum_{m=0}^{\infty} \sum_{k, i, j, l, n, q \geq 0}^{k+i+j+l+n+q=m} \frac{(-1)^{m}}{a_{0} m+1} \frac{m !\left(-k_{n}{ }^{2}\right)^{n+q}}{k ! i ! j ! l ! q !} a_{1}{ }^{k} a_{2}{ }^{i} a_{3}{ }^{j} a_{4}{ }^{l} b_{1}{ }^{n} b_{2}{ }^{q}
$$




$$
\begin{aligned}
& \left\{B _ { n } ( 0 ) \left[a_{0} \frac{s^{\alpha(k+2 i+l+2)+k+\beta n} e^{-s m \tau}}{\left(s^{2 \alpha+1}-\frac{a_{5}}{a_{0}} e^{-s \tau}\right)^{m+1}}+a_{1} \frac{s^{\alpha(k+2 i+l+1)+k+\beta n} e^{-s m \tau}}{\left(s^{2 \alpha+1}-\frac{a_{5}}{a_{0}} e^{-s \tau}\right)^{m+1}}+\right.\right. \\
& +a_{2} \frac{s^{\alpha(k+2 i+l+2)+k+\beta n-1} e^{-s m \tau}}{\left(s^{2 \alpha+1}-\frac{a_{5}}{a_{0}} e^{-s \tau}\right)^{m+1}}+a_{3} \frac{s^{\alpha(k+2 i+l)+k+\beta n} e^{-s m \tau}}{\left(s^{2 \alpha+1}-\frac{a_{5}}{a_{0}} e^{-s \tau}\right)^{m+1}}+ \\
& \left.+a_{4} \frac{s^{\alpha(k+2 i+l+1)+k+\beta n} e^{-s m \tau}}{\left(s^{2 \alpha+1}-\frac{a_{5}}{a_{0}} e^{-s \tau}\right)^{m+1}}+a_{5} e^{-s \tau} \frac{s^{\alpha(k+2 i+l)+k+\beta n} e^{-s m \tau}}{\left(s^{2 \alpha+1}-\frac{a_{5}}{a_{0}} e^{-s \tau}\right)^{m+1}}\right]- \\
& -\frac{2}{k_{n} L}\left[\overline{\varphi_{1}}(s)-(-1)^{n} \overline{\varphi_{2}}(s)\right]\left[a_{0} \frac{s^{\alpha(k+2 i+l+2)+k+\beta n+1} e^{-s m \tau}}{\left(s^{2 \alpha+1}-\frac{a_{5}}{a_{0}} e^{-s \tau}\right)^{m+1}}+a_{1} \frac{s^{\alpha(k+2 i+l+1)+k+\beta n+1} e^{-s m \tau}}{\left(s^{2 \alpha+1}-\frac{a_{5}}{a_{0}} e^{-s \tau}\right)^{m+1}}+\right. \\
& +a_{2} \frac{s^{\alpha(k+2 i+l+2)+k+\beta n} e^{-s m \tau}}{\left(s^{2 \alpha+1}-\frac{a_{5}}{a_{0}} e^{-s \tau}\right)^{m+1}}+a_{3} \frac{s^{\alpha(k+2 i+l)+k+\beta n+1} e^{-s m \tau}}{\left(s^{2 \alpha+1}-\frac{a_{5}}{a_{0}} e^{-s \tau}\right)^{m+1}}+ \\
& \left.+a_{4} \frac{s^{\alpha(k+2 i+l+1)+k+\beta n} e^{-s m \tau}}{\left(s^{2 \alpha+1}-\frac{a_{5}}{a_{0}} e^{-s \tau}\right)^{m+1}}+a_{5} e^{-s \tau} \frac{s^{\alpha(k+2 i+l)+k+\beta n} e^{-s m \tau}}{\left(s^{2 \alpha+1}-\frac{a_{5}}{a_{0}} e^{-s \tau}\right)^{m+1}}\right]+ \\
& +\frac{2}{k_{n} L}\left[d_{n}^{(1)}(0)-B_{n}(0)\right]\left[a_{0} \frac{s^{\alpha(k+2 i+l+2)+k+\beta n} e^{-s m \tau}}{\left(s^{2 \alpha+1}-\frac{a_{5}}{a_{0}} e^{-s \tau}\right)^{m+1}}+a_{1} \frac{s^{\alpha(k+2 i+l+1)+k+\beta n} e^{-s m \tau}}{\left(s^{2 \alpha+1}-\frac{a_{5}}{a_{0}} e^{-s \tau}\right)^{m+1}}+\right. \\
& \left.+a_{2} \frac{s^{\alpha(k+2 i+l+2)+k+\beta n-1} e^{-s m \tau}}{\left(s^{2 \alpha+1}-\frac{a_{5}}{a_{0}} e^{-s \tau}\right)^{m+1}}+a_{3} \frac{s^{\alpha(k+2 i+l)+k+\beta n} e^{-s m \tau}}{\left(s^{2 \alpha+1}-\frac{a_{5}}{a_{0}} e^{-s \tau}\right)^{m+1}}+a_{4} \frac{s^{\alpha(k+2 i+l+1)+k+\beta n-1} e^{-s m \tau}}{\left(s^{2 \alpha+1}-\frac{a_{5}}{a_{0}} e^{-s \tau}\right)^{m+1}}\right]- \\
& -a_{5} G(s) e^{-s \tau} \frac{s^{\alpha(k+2 i+l)+k+\beta n} e^{-s m \tau}}{\left(s^{2 \alpha+1}-\frac{a_{5}}{a_{0}} e^{-s \tau}\right)^{m+1}}+a_{5} \frac{2}{k_{n} L} e^{-s \tau} H(S) \frac{s^{\alpha(k+2 i+l)+k+\beta n} e^{-s m \tau}}{\left(s^{2 \alpha+1}-\frac{a_{5}}{a_{0}} e^{-s \tau}\right)^{m+1}}+ \\
& +F_{n}(s) \frac{s^{\alpha(k+2 i+l)+k+\beta n} e^{-s m \tau}}{\left(s^{2 \alpha+1}-\frac{a_{5}}{a_{0}} e^{-s \tau}\right)^{m+1}} .
\end{aligned}
$$

Applying the discrete inverse Laplace transform to the preceding equation, we obtain

$$
B_{n}(t)=\sum_{m=0}^{\infty} \sum_{k, i, j, l, n, q \geq 0}^{k+i+j+l+n+q=m} \frac{(-1)^{m}}{a_{0}{ }^{m+1}} \frac{m !\left(-k_{n}{ }^{2}\right)^{n+q}}{k ! i ! j ! l ! q !} a_{1}{ }^{k} a_{2}{ }^{i} a_{3}{ }^{j} a_{4}{ }^{l} b_{1}{ }^{n} b_{2}{ }^{q}
$$

$$
\left\{B _ { n } ( 0 ) H ( t - m \tau ) \left[a_{0} G_{2 \alpha+1,-\alpha(k+2 i+l)-k-\beta n+1}^{\left(\frac{a_{5}}{a_{0}}\right), \tau, m}(t-m \tau)+a_{1} G_{2 \alpha+1,-\alpha(k+2 i+l-1)-k-\beta n+1}^{\left(\frac{a_{5}}{a_{0}}\right), \tau, m}(t-m \tau)+\right.\right.
$$$$
+a_{2} G_{2 \alpha+1,-\alpha(k+2 i+l)-k-\beta n+2}^{\left(\frac{a_{5}}{a_{0}}\right), \tau, m}(t-m \tau)+a_{3} G_{2 \alpha+1,-\alpha(k+2 i+l-2)-k-\beta n+1}^{\left(\frac{a_{5}}{a_{0}}\right), \tau, m}(t-m \tau)+
$$$$
\left.+a_{4} G_{2 \alpha+1,-\alpha(k+2 i+l-1)-k-\beta n+2}^{\left(\frac{a_{5}}{a_{0}}\right), \tau, m}(t-m \tau)-b_{1} k_{n}{ }^{2} G_{2 \alpha+1,-\alpha(k+2 i+l-2)-k-\beta n+2}^{\left(\frac{a_{5}}{a_{0}}\right), \tau, m}(t-m \tau)\right]-
$$$$
-\frac{2}{k_{n} L}\left[\int _ { 0 } ^ { t } [ \varphi _ { 1 } ( t - u ) - ( - 1 ) ^ { n } \varphi _ { 2 } ( t - u ) ] H ( u - m \tau ) \left(a_{0} G_{2 \alpha+1,-\alpha(k+2 i+l)-k-\beta n}^{\left(\frac{a_{5}}{a_{0}}\right), \tau, m}(u-m \tau)+\right.\right.
$$

$$
\begin{gathered}
+a_{1} G_{2 \alpha+1,-\alpha(k+2 i+l-1)-k-\beta n}^{\left(\frac{a_{5}}{a_{0}}\right), \tau, m}(u-m \tau)+a_{2} G_{2 \alpha+1,-\alpha(k+2 i+l)-k-\beta n+1}^{\left(\frac{a_{5}}{a_{0}}\right), \tau, m}(u-m \tau)+ \\
\left.\left.+a_{3} G_{2 \alpha+1,-\alpha(k+2 i+l-2)-k-\beta n}^{\left(\frac{a_{5}}{a_{0}}\right), \tau, m}(u-m \tau)+a_{4} G_{2 \alpha+1,-\alpha(k+2 i+l-1)-k-\beta n+1}^{\left(\frac{a_{5}}{a_{0}}\right), \tau, m}(u-m \tau)\right) d u\right]-
\end{gathered}
$$




$$
\begin{gathered}
-a_{5} \frac{2}{k_{n} L} \int_{0}^{t}\left[\varphi_{1}(t-u)-(-1)^{n} \varphi_{2}(t-u)\right] H(u-\tau(m+1)) \\
G_{2 \alpha+1,-\alpha(k+2 i+l-2)-k-\beta n+1}^{\left(\frac{a_{5}}{a_{0}}\right), \tau, m}(u-\tau(m+1)) d u+ \\
+\frac{2}{k_{n} L}\left[d_{n}^{(1)}(0)-B_{n}(0)\right]\left[a_{0} G_{2 \alpha+1,-\alpha(k+2 i+l)-k-\beta n+1}^{\left(\frac{a_{5}}{a_{0}}\right), \tau, m}(t-m \tau)+\right. \\
+a_{1} G_{2 \alpha+1,-\alpha(k+2 i+l-1)-k-\beta n+1}^{\left(\frac{a_{5}}{a_{0}}\right), \tau, m}(t-m \tau)+a_{2} G_{2 \alpha+1,-\alpha(k+2 i+l)-k-\beta n+2}^{\left(\frac{a_{5}}{a_{0}}\right), \tau, m}(t-m \tau)+ \\
\left.+a_{3} G_{2 \alpha+1,-\alpha(k+2 i+l-2)-k-\beta n+1}^{\left(\frac{a_{5}}{a_{0}}\right), \tau, m}(t-m \tau)+a_{4} G_{2 \alpha+1,-\alpha(k+2 i+l-1)-k-\beta n+2}^{\left(\frac{a_{5}}{a_{0}}\right), \tau, m}(t-m \tau)\right]- \\
-a_{5} \int_{0}^{t} g(t-u) H(u-\tau(m+1)) G_{2 \alpha+1,-\alpha(k+2 i+l-2)-k-\beta n+1}^{\left(\frac{a_{5}}{a_{0}}\right), \tau, m}(u-\tau(m+1)) d u- \\
-a_{5} \frac{2}{k_{n} L} \int_{0}^{t} h(t-u) H(u-\tau(m+1)) G_{2 \alpha+1,-\alpha(k+2 i+l-2)-k-\beta n+1}^{\left(\frac{a_{5}}{a_{0}}\right), \tau, m}(u-\tau(m+1)) d u+ \\
+\int_{0}^{t} f_{n}(t-u) H(u-m \tau) G_{2 \alpha+1,-\alpha(k+2 i+l-2)-k-\beta n+1}^{\left(\frac{a_{5}}{a_{0}}\right), \tau, m}(u-\tau(m+1)) d u
\end{gathered}
$$

Once the $B_{n}(t)$ are known, so are the $W(y, t)$, and thus $u(y, t)$ as desired.

$$
3.2\left(\frac{1}{2} \leq \alpha, \beta \leq 1\right)
$$

In the same way in the subsection 3.1 we could have

$$
B_{n}(t)=\sum_{m=0}^{\infty} \sum_{k, i, j, l, n, q \geq 0}^{k+i+j+l+n+q=m} \frac{(-1)^{m}}{a_{0}{ }^{m+1}} \frac{m !\left(-k_{n}{ }^{2}\right)^{n+q}}{k ! i ! j ! l ! q !} a_{1}{ }^{k} a_{2}{ }^{i} a_{3}{ }^{j} a_{4}{ }^{l} b_{1}{ }^{n} b_{2}{ }^{q}
$$

$\left\{B_{n}(0) H(t-m \tau)\left[a_{0} G_{2 \alpha+1,-\alpha(k+2 i+l)-k-\beta n+1}^{\left(\frac{a_{5}}{a_{0}}\right), \tau, m}(t-m \tau)+a_{1} G_{2 \alpha+1,-\alpha(k+2 i+l-1)-k-\beta n+1}^{\left(\frac{a_{5}}{a_{0}}\right), \tau, m}(t-m \tau)+\right.\right.$

$$
\begin{aligned}
& +a_{2} G_{2 \alpha+1,-\alpha(k+2 i+l)-k-\beta n+2}^{\left(\frac{a_{5}}{a_{0}}\right), \tau, m}(t-m \tau)+a_{3} G_{2 \alpha+1,-\alpha(k+2 i+l-2)-k-\beta n+1}^{\left(\frac{a_{5}}{a_{0}}\right), \tau, m}(t-m \tau)+ \\
+ & \left.a_{4} G_{2 \alpha+1,-\alpha(k+2 i+l-1)-k-\beta n+2}^{\left(\frac{a_{5}}{a_{0}}\right), \tau, m}(t-m \tau)-b_{1} k_{n}{ }^{2} G_{2 \alpha+1,-\alpha(k+2 i+l-2)-k-\beta n+2}^{\left(\frac{a_{5}}{a_{0}}\right), \tau, m}(t-m \tau)\right]+
\end{aligned}
$$

$+B^{\prime}{ }_{n}(0) H(t-m \tau)\left[a_{0} G_{2 \alpha+1,-\alpha(k+2 i+l)-k-\beta n+2}^{\left(\frac{a_{5}}{a_{0}}\right), \tau, m}(t-m \tau)+a_{1} G_{2 \alpha+1,-\alpha(k+2 i+l-1)-k-\beta n+2}^{\left(\frac{a_{5}}{a_{0}}\right), \tau, m}(t-m \tau)+\right.$

$$
\begin{aligned}
& \left.+a_{2} G_{2 \alpha+1,-\alpha(k+2 i+l)-k-\beta n+3}^{\left(\frac{a_{5}}{a_{0}}\right), \tau, m}(t-m \tau)+a_{4} G_{2 \alpha+1,-\alpha(k+2 i+l-1)-k-\beta n+3}^{\left(\frac{a_{5}}{a_{0}}\right), \tau, m}(t-m \tau)\right]+ \\
& \quad+B_{n}^{\prime \prime}(0) a_{0} G_{2 \alpha+1,-\alpha(k+2 i+l)-k-\beta n+3}^{\left(\frac{a_{5}}{a_{0}}\right), \tau, m}(t-m \tau)- \\
& -\frac{2}{k_{n} L}\left[\int _ { 0 } ^ { t } [ \varphi _ { 1 } ( t - u ) - ( - 1 ) ^ { n } \varphi _ { 2 } ( t - u ) ] H ( u - m \tau ) \left(a_{0} G_{2 \alpha+1,-\alpha(k+2 i+l)-k-\beta n}^{\left(\frac{a_{5}}{a_{0}}\right), \tau, m}(u-m \tau)+\right.\right. \\
& \quad+a_{1} G_{2 \alpha+1,-\alpha(k+2 i+l-1)-k-\beta n}^{\left(\frac{a_{5}}{a_{0}}\right), \tau, m}(u-m \tau)+a_{2} G_{2 \alpha+1,-\alpha(k+2 i+l)-k-\beta n+1}^{\left(\frac{a_{5}}{a_{0}}\right), \tau, m}(u-m \tau)+ \\
& \left.\left.+a_{3} G_{2 \alpha+1,-\alpha(k+2 i+l-2)-k-\beta n}^{\left(\frac{a_{5}}{a_{0}}\right), \tau, m}(u-m \tau)+a_{4} G_{2 \alpha+1,-\alpha(k+2 i+l-1)-k-\beta n+1}^{\left(\frac{a_{5}}{a_{0}}\right), \tau, m}(u-m \tau)\right) d u\right]-
\end{aligned}
$$




$$
\begin{aligned}
& -a_{5} \frac{2}{k_{n} L} \int_{0}^{t}\left[\varphi_{1}(t-u)-(-1)^{n} \varphi_{2}(t-u)\right] H(u-\tau(m+1)) G_{2 \alpha+1,-\alpha(k+2 i+l-2)-k-\beta n+1}^{\left(\frac{a_{5}}{a_{0}}\right), \tau, m}(u-\tau(m+1)) d u+ \\
& +\frac{2}{k_{n} L}\left[d_{n}^{(1)}(0)-B_{n}(0)\right]\left[a_{0} G_{2 \alpha+1,-\alpha(k+2 i+l)-k-\beta n+2}^{\left(\frac{a_{5}}{a_{0}}\right), \tau, m}(t-m \tau)+\right. \\
& \left.+a_{1} G_{2 \alpha+1,-\alpha(k+2 i+l-1)-k-\beta n+2}^{\left(\frac{a_{5}}{a_{0}}\right), \tau, m}(t-m \tau)+a_{2} G_{2 \alpha+1,-\alpha(k+2 i+l)-k-\beta n+3}^{\left(\frac{a_{5}}{a_{0}}\right), \tau, m}(t-m \tau)\right]+ \\
& +\frac{2}{k_{n} L}\left[d_{n}^{(2)}(0)-B_{n}^{\prime}(0)\right]\left[a_{0} G_{2 \alpha+1,-\alpha(k+2 i+l)-k-\beta n+2}^{\left(\frac{a_{5}}{a_{0}}\right), \tau, m}(t-m \tau)+\right. \\
& \left.+a_{1} G_{2 \alpha+1,-\alpha(k+2 i+l-1)-k-\beta n+2}^{\left(\frac{a_{5}}{a_{0}}\right), \tau, m}(t-m \tau)+a_{2} G_{2 \alpha+1,-\alpha(k+2 i+l)-k-\beta n+3}^{\left(\frac{a_{5}}{a_{0}}\right), \tau, m}(t-m \tau)\right]+ \\
& +\frac{2}{k_{n} L}\left[d_{n}^{(3)}(0)-B_{n}^{\prime \prime}(0)\right] a_{0} G_{2 \alpha+1,-\alpha(k+2 i+l)-k-\beta n+3}^{\left(\frac{a_{5}}{a_{0}}\right), \tau, m}(t-m \tau)- \\
& -a_{5} \int_{0}^{t} g(t-u) H(u-\tau(m+1)) G_{2 \alpha+1,-\alpha(k+2 i+l-2)-k-\beta n+1}^{\left(\frac{a_{5}}{a_{0}}\right), \tau, m}(u-\tau(m+1)) d u- \\
& -a_{5} \frac{2}{k_{n} L} \int_{0}^{t} h(t-u) H(u-\tau(m+1)) G_{2 \alpha+1,-\alpha(k+2 i+l-2)-k-\beta n+1}^{\left(\frac{a_{5}}{a_{0}}\right), \tau, m}(u-\tau(m+1)) d u+ \\
& \left.+\int_{0}^{t} f_{n}(t-u) H(u-m \tau) G_{2 \alpha+1,-\alpha(k+2 i+l-2)-k-\beta n+1}^{\left(\frac{a_{5}}{a_{0}}\right), \tau, m}(u-\tau(m+1)) d u\right\} .
\end{aligned}
$$

\section{Examples}

We consider the flow of an Oldroyd-B fluid when the body force and the pressure gradient are omitted and the plate is accelerating. We present the analytical solution in the different initial conditions

Example 1. In this example the plate is moving at speed $c t$, where $c$ is constant. The corresponding initial problem is then given as

$$
\begin{gathered}
\frac{\partial u(y, t)}{\partial t}+\lambda_{\alpha} D_{t}^{\alpha} u(y, t)+\theta D_{t}^{2 \alpha} u(y, t)=\nu \frac{\partial^{2} u(y, t)}{\partial y^{2}}+\nu \lambda_{\beta} D_{t}^{\beta} \frac{\partial^{2} u(y, t)}{\partial y^{2}}-M u(y, t-\tau) \\
u(y, t)=c_{1}, \quad u(0, t)=c t, \quad-\tau \leq t \leq 0, \quad y>0, \\
u_{t}(y, t)=c_{2}, \quad u(L, t)=0, \quad \frac{1}{2}<\alpha, \beta<1 \\
u_{t t}(y, t)=0 .
\end{gathered}
$$

Separating variables and use of the Laplace transformation yields,

$$
\begin{aligned}
& \bar{B}_{n}(s)=e^{s m \tau} \sum_{m=0}^{\infty} \sum_{k, i, j \geq 0}^{k+i+j=m} \frac{(-1)^{m}}{(\theta)^{m+1}} \frac{m !\left(-k_{n}{ }^{2} \nu\right)^{j+l} \lambda_{\beta}{ }^{l} \lambda_{\alpha}{ }^{i}}{k ! i ! j ! l !} \\
& \left\{B _ { n } ( 0 ) \left[\frac{s^{k+\alpha i+\beta l} e^{-s m \tau}}{\left(s^{2 \alpha}-\frac{M}{\theta} e^{-s \tau}\right)^{m+1}}+\lambda_{\alpha} \frac{s^{k+\alpha(i+1)+\beta l-1} e^{-s m \tau}}{\left(s^{2 \alpha}-\frac{M}{\theta} e^{-s \tau}\right)^{m+1}}+\theta \frac{s^{k+\alpha(i+2)+\beta l-1} e^{-s m \tau}}{\left(s^{2 \alpha}-\frac{M}{\theta} e^{-s \tau}\right)^{m+1}}\right.\right. \\
& \left.-\nu \lambda_{\beta} k_{n}{ }^{2} \frac{s^{k+\alpha i+\beta(1+l)-1} e^{-s m \tau}}{\left(s^{2 \alpha}-\frac{M}{\theta} e^{-s \tau}\right)^{m+1}}\right]+B^{\prime}{ }_{n}(0)\left[\lambda_{\alpha} \frac{s^{k+\alpha(1+i)+\beta l-2} e^{-s m \tau}}{\left(s^{2 \alpha}-\frac{M}{\theta} e^{-s \tau}\right)^{m+1}}+\theta \frac{s^{k+\alpha(i+2)+\beta l-2} e^{-s m \tau}}{\left(s^{2 \alpha}-\frac{M}{\theta} e^{-s \tau}\right)^{m+1}}\right. \\
& \left.+\nu \lambda_{\beta} k_{n}{ }^{2} \frac{s^{k+\alpha i+\beta(1+l)-2} e^{-s m \tau}}{\left(s^{2 \alpha}-\frac{M}{\theta} e^{-s \tau}\right)^{m+1}}\right]-M e^{-s \tau} G(s) \frac{s^{k+\alpha i+\beta l} e^{-s m \tau}}{\left(s^{2 \alpha}-\frac{M}{\theta} e^{-s \tau}\right)^{m+1}} \\
& +\frac{2 c}{k_{n} L}\left[\frac{s^{k+\alpha i+\beta l-1} e^{-s m \tau}}{\left(s^{2 \alpha}-\frac{M}{\theta} e^{-s \tau}\right)^{m+1}}-M e^{-s \tau} \frac{s^{k+\alpha i+\beta l-2} e^{-s m \tau}}{\left(s^{2 \alpha}-\frac{M}{\theta} e^{-s \tau}\right)^{m+1}}+M e^{-s \tau} H(s) \frac{s^{k+\alpha i+\beta l} e^{-s m \tau}}{\left(s^{2 \alpha}-\frac{M}{\theta} e^{-s \tau}\right)^{m+1}}-\lambda_{\alpha} \frac{s^{k+\alpha(1+i)+\beta l-2} e^{-s m \tau}}{\left(s^{2 \alpha}-\frac{M}{\theta} e^{-s \tau}\right)^{m+1}}\right. \\
& \left.\left.-\theta \Gamma(-\alpha+2) \frac{s^{k+\alpha(2+i)+\beta l-2} e^{-s m \tau}}{\left(s^{2 \alpha}-\frac{M}{\theta} e^{-s \tau}\right)^{m+1}}\right]\right\} .
\end{aligned}
$$


Taking inverse Laplace transform gives us

$B_{n}(t)=\sum_{m=0}^{\infty} \sum_{k, i, j \geq 0}^{k+i+j=m} \frac{(-1)^{m}}{(\theta)^{m+1}} \frac{m !\left(-k_{n}{ }^{2} \nu\right)^{j+l} \lambda_{\beta}{ }^{l} \lambda_{\alpha}{ }^{i}}{k ! i ! j ! ! !}$

$\left\{B_{n}(0) H(t-m \tau)\left[G_{2 \alpha,-k-\alpha(i-2)-\beta l}^{\left(\frac{M}{\theta}\right), \tau, m}(t-m \tau)+\lambda_{\alpha} G_{2 \alpha,-k-\alpha(i-1)-\beta l+1}^{\left(\frac{M}{\theta}\right), \tau, m}(t-m \tau)+\theta G_{2 \alpha,-k-\alpha i-\beta l+1}^{\left(\frac{M}{\theta}\right), \tau, m}(t-m \tau)\right.\right.$

$\left.-\nu \lambda_{\beta} k_{n}^{2} G_{2 \alpha,-k-\alpha(i-2)-\beta(1+l)+1}^{\left(\frac{M}{\theta}\right), \tau, m}(t-m \tau)\right]$

$+B^{\prime}{ }_{n}(0)\left[\lambda_{\alpha} G_{2 \alpha,-k-\alpha(i-1)-\beta l+2}^{\left(\frac{M}{\theta}\right), \tau, m}(t-m \tau)+\theta G_{2 \alpha,-k-\alpha i-\beta l+2}^{\left(\frac{M}{\theta}\right), \tau, m}(t-m \tau)\right.$

$\left.+\nu \lambda_{\beta} k_{n}^{2} G_{2 \alpha,-k-\alpha(i-2)-\beta(l+1)+2}^{\left(\frac{M}{\theta}\right), \tau, m}(t-m \tau)\right]$

$-M \int_{0}^{t} g(t-u) H(u-\tau(m+1)) G_{2 \alpha,-k-\alpha(i-2)-\beta l}^{\left(\frac{M}{\theta}\right), \tau, m}(u-\tau(m+1)) d u$

$+\frac{2 c}{k_{n} L} H(t-m \tau)\left[G_{2 \alpha,-k-\alpha(i-2)-\beta l+1}^{\left(\frac{M}{\theta}\right), \tau, m}(t-m \tau)-\lambda_{\alpha} G_{2 \alpha,-k-\alpha(i-1)-\beta l+2}^{\left(\frac{M}{\theta}\right), \tau, m}(t-m \tau)\right.$

$\left.-\theta \Gamma(-\alpha+2) G_{2 \alpha,-k-\alpha i-\beta l+2}^{\left(\frac{M}{\theta}\right), \tau, m}(t-m \tau)\right]$

$+\frac{2 c M}{k_{n} L} H(t-\tau(m+1)) G_{2 \alpha,-k-\alpha(i-2)-\beta l+2}^{\left(\frac{M}{\theta}\right), \tau, m}(t-\tau(m+1))$

$\left.+\frac{2 c}{k_{n} L} \int_{0}^{t} h(t-u) H(u-\tau(m+1)) G_{2 \alpha,-k-\alpha(i-2)-\beta l}^{\left(\frac{M}{\theta}\right), \tau, m}(u-\tau(m+1)) d u\right\}$.

Example 2. We consider the flow of an Oldroyd-B fluid with the initial conditions $\psi_{1}(y)=c, \psi_{2}(y)=0$ and boundary conditions, $\varphi_{1}(t)=c t, \varphi_{2}(t)=0$ where $\mathrm{c}$ is constant. The problem now becomes,

$$
\begin{gathered}
\frac{\partial u(y, t)}{\partial t}+\lambda_{\alpha} D_{t}^{\alpha} u(y, t)=\nu \frac{\partial^{2} u(y, t)}{\partial y^{2}}+\nu \lambda_{\beta} D_{t}^{\beta} \frac{\partial^{2} u(y, t)}{\partial y^{2}}-M u(y, t-\tau) \\
u(y, t)=c, \quad u(0, t)=c t, \quad-\tau \leq t \leq 0, y>0 \\
u_{t}(y, t)=0, \quad u(L, t)=0, \quad 0<\alpha, \beta<\frac{1}{2} .
\end{gathered}
$$

Using the preceding method we obtain,

$$
\begin{aligned}
& B_{n}(t)=\sum_{m=0}^{\infty} \sum_{k, i, j, q \geq 0}^{k+i+j+q=m} \frac{(-1)^{m}}{\left(M \lambda_{\alpha}\right)^{m+1}} \frac{m !\left(-k_{n}{ }^{2} \nu\right)^{i+j} \lambda_{\beta}{ }^{j}}{k ! i ! j !} \\
& \left\{B _ { n } ( 0 ) H ( t - m \tau ) \left[G_{\alpha, \alpha-k-\beta j}^{\left(\frac{M}{\lambda_{\alpha}}\right), \tau, m}(t-m \tau)+\lambda_{\alpha} G_{\alpha,-k-\beta q+1}^{\left(\frac{M}{\lambda_{\alpha}}\right), \tau, m}(t-m \tau)\right.\right. \\
& \left.-\nu \lambda_{\beta} k_{n}{ }^{2} G_{\alpha, \alpha-k-\beta(j+1)+1}^{\left(\frac{M}{\lambda_{\alpha}}\right), \tau, m}(t-m \tau)\right]-M \int_{0}^{t} g(t-u) H(u-\tau(m+1)) G_{\alpha, \alpha-k-\beta j}^{\left(\frac{M}{\lambda_{\alpha}}\right), \tau, m}(u-\tau(m+1)) d u \\
& +\frac{2 c}{k_{n} L} H(t-m \tau)\left[G_{\alpha, \alpha-k-\beta j+1}^{\left(\frac{M}{\lambda_{\alpha}}\right), \tau, m}(t-m \tau)-\lambda_{\alpha} G_{\alpha,-k-\beta j+2}^{\left(\frac{M}{\lambda_{\alpha}}\right), \tau, m}(t-m \tau)\right] \\
& +\frac{2 c M}{k_{n} L} H(t-\tau(m+1)) G_{\alpha, \alpha-k-\beta j+2}^{\left(\frac{M}{\lambda_{\alpha}}\right), \tau, m}(t-\tau(m+1) \\
& \left.+\frac{2 c}{k_{n} L} \int_{0}^{t} h(t-u) H(u-\tau(m+1)) G_{\alpha, \alpha-k-\beta j}^{\left(\frac{M}{\lambda_{\alpha}}\right), \tau, m}(t-m \tau) d u\right\}, \text { after which } W(y, t) \text { and so } u(y, t) \text { may be found. }
\end{aligned}
$$

\section{Conclusion}

In this paper we used a variant of the method of separation of variables to simplify the governing fractionalorder partial differential equations of a generalized viscoelastic Oldroyd-B fluid with constant delay in time to a set of fractional-order ordinary differential equations with homogeneous boundary condition. The Laplace transformation (followed by its inverse) was then employed to obtain the exact solutions of the linear fractional ordinary differential equation. The solutions are given in terms of multivariate Green functions. We found exact solutions for three specific situations illustrated by examples.

\section{References}

1 Podlubny, I. (1998). Fractional differential equations: an introduction to fractional derivatives, fractional differential equations, to methods of their solution and some of their applications. Vol. 198, Elsevier. 
2 Diethelm, K., \& Freed, A.D. (1999). On the solution of nonlinear fractional-order differential equations used in the modeling of viscoplasticity. Springer.

3 Magin, R.L. (2006). Fractional calculus in bioengineering. Begell House Redding.

4 Kilbas, A.A.A., Srivastava, H.M., \& Trujillo, J.J. (2006). Theory and applications of fractional differential equations. Vol. 204, Elsevier Science Limited.

5 Fetecau, C., Fetecau, C., Khan, M., \& Vieru, D. (2008). Decay of a potential vortex in a generalized Oldroyd-B fluid. Applied Mathematics and Computation, 205 (1), 497-506.

6 Khan, M. (2009). The Rayleigh-Stokes problem for an edge in a viscoelastic fluid with a fractional derivative model. Nonlinear Analysis: Real World Applications 10(5), 3190-3195.

7 Nadeem, S. (2007). General periodic flows of fractional Oldroyd-B fluid for an edge. Physics Letters A, $368(3-4), 181-187$.

8 Song, D.Y., \& Jiang, T.Q. (1998). Study on the constitutive equation with fractional derivative for the viscoelastic fluids - Modified Jeffreys model and its application. Rheologica Acta, 37(5), 512-517.

9 Hilfer, R. (2000). Applications of Fractional Calculus in Physics. Edited by HILFER R: Published by World Scientific Publishing Co. Pte. Ltd.

10 Tong, D., Zhang, X., \& Zhang, X. (2009). Unsteady helical flows of a generalized Oldroyd-B fluid. Journal of non-newtonian fluid mechanics, 156(1-2), 75-83.

11 Haitao, Q., \& Mingyu, X. (2009). Some unsteady unidirectional flows of a generalized Oldroyd-B fluid with fractional derivative. Applied Mathematical Modelling, 33(11), 4184-4191.

12 Fetecau, C., Fetecau, C., Kamran, M., \& Vieru, D. (2009). Exact solutions for the flow of a generalized Oldroyd-B fluid induced by a constantly accelerating plate between two side walls perpendicular to the plate. Journal of Non-Newtonian Fluid Mechanics, 156(3), 189-201.

13 Vieru, D., Fetecau, C., \& Fetecau, C. (2008). Flow of a generalized Oldroyd-B fluid due to a constantly accelerating plate. Applied Mathematics and Computation, 201 (1-2), 834-842.

14 Shah, S. H. A. M., Khan, M., \& Qi, H. (2009). Exact solutions for a viscoelastic fluid with the generalized Oldroyd-B model. Nonlinear Analysis: Real World Applications, 10(4), 2590-2599.

15 Qi, H., \& Jin, H. (2009). Unsteady helical flows of a generalized Oldroyd-B fluid with fractional derivative. Nonlinear analysis: real world applications, 10(5), 2700-2708.

16 Zheng, L., Liu, Y., \& Zhang, X. (2011). Exact solutions for MHD flow of generalized Oldroyd-B fluid due to an infinite accelerating plate. Mathematical and Computer Modelling, 54 (1-2), 780-788.

17 Hayat, T., Khan, M., \& Asghar, S. (2007). On the MHD flow of fractional generalized burgers fluid with modified darcy law. Acta Mechanica Sinica, 23(3), 257-261.

18 Heris, M.S., \& Javidi, M. (2017). On fractional backward differential formulas for fractional delay differential equations with periodic and anti-periodic conditions. Applied Numerical Mathematics, 118, $203-220$.

19 Wang, Z., Huang, X., \& Shi, G. (2011). Analysis of nonlinear dynamics and chaos in a fractional order financial system with time delay. Computers and Mathematics with Applications, 62 (3), 1531-1539.

20 Heris, M.S., \& Javidi, M. (2018). On fractional backward differential formulas methods for fractional differential equations with delay. International Journal of Applied and Computational Mathematics, $4(2), 72$.

21 Morgado, M.L., Ford, N.J., \& Lima, P.M. (2013). Analysis and numerical methods for fractional differential equations with delay. Journal of computational and applied mathematics, 252, 159-168.

22 Čermák, J., Horníček, J., \& Kisela, T. (2016). Stability regions for fractional differential systems with a time delay. Communications in Nonlinear Science and Numerical Simulation, 31(1-3), 108-123.

23 Lazarević, M.P., \& Spasić, A.M. (2009). Finite-time stability analysis of fractional order time-delay systems: Gronwall approach. Mathematical and Computer Modelling, 49(3-4), 475-481.

24 Heris, M.S., \& Javidi, M. (2017). On fbdf5 method for delay differential equations of fractional order with periodic and anti-periodic conditions. Mediterranean Journal of Mathematics, $14(3), 134$.

25 Jiang, H., Liu, F., Turner, I., \& Burrage, K. (2012). Analytical solutions for the multi-term time-space caputo-riesz fractional advection-diffusion equations on a finite domain. Journal of Mathematical Analysis and Applications, 389(2), 1117-1127. 


\author{
С. Сагали ${ }^{1}$, Ф.Д. Саи ${ }^{1}$, М. Джавиди ${ }^{2}$, М.Дж. Рад ${ }^{1}$ \\ ${ }^{1}$ Азад Ислам университетінін, Тебриздегі филиаль, Тебриз, Иран; \\ ${ }^{2}$ Тебриз университеті, Тебриз, Иран
}

\title{
Тұтқыр сығынды сұйықтықтар теориясының бөлшек дифференциалдық теңдеуінің аналитикалық шешімі
}

\begin{abstract}
Мақаланың мақсаты - Олдройд-Б сығылмайтын жалпылама сұйықтығын Капуто түріндегі бөлшек туындыларымен кешіктіру арқылы бөлшек дифференциалдық теңдеулердің аналитикалық шешімдерін ұсыну. Айнымалыларды бөлу әдісінің модификациясын қолдана отырып, біртекті емес шекаралық шарттары бар негізгі теңдеу біртекті шекаралық шарттары бар теңдеуге айналады, содан кейін алынған шешімдер Лаплас түрлендірулерінің көмегімен Грин функциялары арқылы көрінеді. Бұл нәтижелер екі жағдайда ұсынылған: бірінші қадамда $0 \leq \alpha, \beta \leq \frac{1}{2}$, ал екінші қадамда $\frac{1}{2} \leq \alpha, \beta \leq 1$, әр қадам үшін 1, 2 Олдройд-Б жалпыланған сұйықтығының стационарлық емес ағымдары үшін, оның ішінде жылжымалы плитасы бар ағын мысалдармен қарастырылды.
\end{abstract}

Kiлm сөздер: Олдройд-Б сұйықтығы, бөлшек ретті жартылай туындылардағы теңдеулер, аналитикалық шешімдер, кешіктірілген дифференциалдық теңдеу, айнымалыларды бөлудің модификацияланған әдісі, Капутоның бөлшек туындылары.

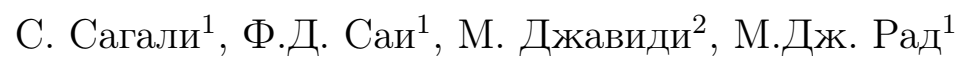 \\ ${ }^{1}$ Филиал Исламского университета Азад в Тебризе, Тебриз, Иран; \\ ${ }^{2}$ Университет Тебриза, Тебриз, Иран
}

\section{Аналитическое решение дробного дифференциального уравнения теории вязкоупругих жидкостей}

Цель данной статьи - представить аналитические решения дробных дифференциальных уравнений с запаздыванием несжимаемой обобщенной жидкости Олдройда-Б с дробными производными типа Капуто. Используя модификацию метода разделения переменных, основное уравнение с неоднородными граничными условиями преобразуется в уравнение с однородными граничными условиями, а полученные решения затем выражаются через функции Грина с помощью преобразований Лапласа. Эти результаты представлены в двух условиях: на первом шаге, когда $0 \leq \alpha, \beta \leq \frac{1}{2}$, а на втором - при $\frac{1}{2} \leq \alpha, \beta \leq 1$. Для каждого шага 1,2 для нестационарных течений обобщенной жидкости Олдройда-Б, включая поток с движущейся пластиной, приведены примеры.

Ключевые слова: жидкость Олдройда-Б, уравнения в частных производных дробного порядка, аналитические решения, дифференциальное уравнение с запаздыванием, модифицированный метод разделения переменных, дробные производные Капуто. 


\author{
O.A.Tarasova ${ }^{1}$, A.V.Vasilyev ${ }^{2}$, V.B.Vasilyev ${ }^{1, *}$ \\ ${ }^{1}$ Belgorod State National Research University, Belgorod, Russia; \\ ${ }^{2}$ OOO "Severgrup", Moscow, Russia \\ (E-mail: tarasova_o@bsu.edu.ru, alexvassel@gmail.com,vladimir.b.vasilyev@gmail.com)
}

\title{
On Discrete Solutions for Elliptic Pseudo-Differential Equations
}

\begin{abstract}
We consider discrete analogue for simplest boundary value problem for elliptic pseudo-differential equation in a half-space with Dirichlet boundary condition in Sobolev-Slobodetskii spaces. Based on the theory of discrete boundary value problems for elliptic pseudo-differential equations we give a comparison between discrete and continuous solutions for certain model boundary value problem.
\end{abstract}

Keywords: Digital pseudo-differential operator, Discrete solution, Discrete boundary value problem, Rate of approximation.

\section{Introduction}

As soon as boundary value problems for partial differential equations were formulated, then at the same time the necessity of solving methods has appeared. Since finding exact solution for these problems is a very seldom phenomenon, numerical and approximate methods are extensively used. According to development of computer technologies, a preference is given to such methods which can be easily realized by computers.

There are a lot of approximate methods for solving boundary value problems in mathematical literature (see, for example, classical books [1-4] and many others) All authors consider a priori given boundary value problem and construct for it certain approximate structures. As a rule this way leads to final system of linear algebraic equations and the solution of the latter system us declared as an approximate solution for the starting problem.

In our opinion there is a reason to study discrete objects initially and then to apply their properties for studying approximation of starting continuous objects. This approach was started from papers [5-10] and further it was developed in [11-15]. We based on Eskin's approach for elliptic model pseudo-differential equations in a half-space [5] and have developed appropriate discrete theory. This report is devoted to a special case how we can approximate the infinite discrete objects by finite ones.

\section{Digital Operators and Discrete Equations}

We will use the following notations. Let $\mathbf{T}^{m}$ be $m$-dimensional cube $[-\pi, \pi]^{m}, h>0, \hbar=h^{-1}$. We will consider all functions defined in the cube as periodic functions in $\mathbf{R}^{m}$ with the same cube of periods.

If $u_{d}(\tilde{x}), \tilde{x} \in h \mathbf{Z}^{m}$ is a function of a discrete variable, then we call it "discrete function". For such discrete functions one can define the discrete Fourier transform

$$
\left(F_{d} u_{d}\right)(\xi) \equiv \tilde{u}_{d}(\xi)=\sum_{\tilde{x} \in h \mathbf{Z}^{m}} e^{-i \tilde{x} \cdot \xi} u_{d}(\tilde{x}) h^{m}, \quad \xi \in \hbar \mathbf{T}^{m},
$$

if the latter series converges, and the function $\tilde{u}_{d}(\xi)$ is a periodic function on $\mathbf{R}^{m}$ with the basic cube of periods $\hbar \mathbf{T}^{m}$. This discrete Fourier transform preserves basic properties of the integral Fourier transform, particularly the inverse discrete Fourier transform is given by the formula

$$
\left(F_{d}^{-1} \tilde{u}_{d}\right)(\tilde{x})=\frac{1}{(2 \pi)^{m}} \int_{\hbar \mathbf{T}^{m}} e^{i \tilde{x} \cdot \xi} \tilde{u}_{d}(\xi) d \xi, \quad \tilde{x} \in h \mathbf{Z}^{m} .
$$

${ }^{*}$ Corresponding author.

E-mail: vladimir.b.vasilyev@gmail.com 
Let $\mathbf{T}^{m}=[-\pi, \pi]^{m}, h>0, A_{d}(\xi), \xi \in \mathbf{R}^{m}$ be a periodic function with basic cube of periods $\hbar \mathbf{T}^{m}, D \subset \mathbf{R}^{m}$ be a domain. We introduce a digital pseudo-differential operator

$$
\left(A_{d} u_{d}\right)(\tilde{x})=\sum_{\tilde{y} \in h \mathbf{Z}^{m}} \int_{\hbar \mathbf{T}^{m}} A_{d}(\xi) e^{i(\tilde{y}-\tilde{x}) \cdot \xi} u_{d}(\tilde{y}) d \xi h^{m}, \quad \tilde{x} \in D_{d} \equiv D \cap h \mathbf{Z}^{m},
$$

which is defined for functions of a discrete variable $\tilde{x} \in h \mathbf{Z}^{m}$.

We study operator equations

$$
A_{d} u_{d}=v_{d}
$$

its solvability and approximate properties for small $h$.

Let us denote $\zeta^{2}=h^{-2} \sum_{k=1}^{m}\left(e^{-i h \cdot \xi_{k}}-1\right)^{2}, S\left(h \mathbf{Z}^{m}\right)$ is a discrete analogue of the Schwartz space $S\left(\mathbf{R}^{m}\right)$ [7] and introduce the following:

Definition 1. The space $H^{s}\left(h \mathbf{Z}^{m}\right)$ is a closure of the space $S\left(h \mathbf{Z}^{m}\right)$ with respect to the norm

$$
\left\|u_{d}\right\|_{s}=\left(\int_{\hbar \mathbf{T}^{m}}\left(1+\left|\zeta^{2}\right|\right)^{s}\left|\tilde{u}_{d}(\xi)\right|^{2} d \xi\right)^{1 / 2} .
$$

Further, let $D \subset \mathbf{R}^{m}$ be a domain, and $D_{d}=D \cap h \mathbf{Z}^{m}$ be a discrete domain.

Definition 2. The space $H^{s}\left(D_{d}\right)$ consists of discrete functions from $H^{s}\left(h \mathbf{Z}^{m}\right)$ which supports belong to $\overline{D_{d}}$. A norm in the space $H^{s}\left(D_{d}\right)$ is induced by a norm of the space $H^{s}\left(h \mathbf{Z}^{m}\right)$. The space $H_{0}^{s}\left(D_{d}\right)$ consists of discrete functions $u_{d}$ with a support in $D_{d}$, and these discrete functions should admit a continuation into the whole $H^{s}\left(h \mathbf{Z}^{m}\right)$. A norm in the $H_{0}^{s}\left(D_{d}\right)$ is given by the formula

$$
\left\|u_{d}\right\|_{s}^{+}=\inf \left\|\ell u_{d}\right\|_{s}
$$

where infimum is taken over all continuations $\ell$.

Of course, all such norms are equivalent to the $L_{2}$-norm but this equivalence depends on $h$. Let us note that all constants below in our considerations do not depend on $h$.

To study the equation (1) in a discrete half-space $\left(D=\mathbf{R}_{+}^{m} \equiv\left\{x \in \mathbf{R}^{m}: x-\left(x^{\prime}, x_{m}\right), x_{m}>0\right\}\right)$ we use a special factorization for the symbol $A_{d}(\xi)$

$$
A_{d}(\xi)=A_{d,+}(\xi) \cdot A_{d,-}(\xi)
$$

where the factors $\tilde{A}_{ \pm}(\xi)$ admit a holomorphic continuation into half-strips $\hbar \Pi_{ \pm}$,

$$
\Pi_{ \pm}=\left\{z \in \mathbf{C}: z=\xi_{m}+i \tau, \xi_{m} \in\left[-h^{-1} \pi, h^{-1} \pi\right], \pm \tau>0\right\} .
$$

with respect to the last variable $\xi_{m}$ under fixed $\left(\xi_{1}, \cdots, \xi_{m-1}\right) \in \hbar \mathbf{T}^{m-1}$ and satisfy some estimates [1-3].

\section{Discrete Equations}

We consider the class $E_{\alpha}$, which includes symbols satisfying the following condition

$$
c_{1}\left(1+\left|\zeta^{2}\right|\right)^{\alpha / 2} \leq\left|A_{d}(\xi)\right| \leq c_{2}\left(1+\left|\zeta^{2}\right|\right)^{\alpha / 2}
$$

with universal positive constants $c_{1}, c_{2}$ non-depending on $h$ and the symbol $A_{d}(\xi)$.

Definition 3. Periodic factorization of an elliptic symbol $A_{d}(\xi) \in E_{\alpha}$ is called its representation in the form

$$
A_{d}(\xi)=A_{d,+}(\xi) A_{d,-}(\xi)
$$

where the factors $A_{d, \pm}(\xi)$ admit an analytical continuation into half-strips $\hbar \Pi_{ \pm}$on the last variable $\xi_{m}$ for almost all fixed $\xi^{\prime} \in \hbar \mathbf{T}^{m-1}$ and satisfy the estimates

$$
\left|A_{d,+}^{ \pm 1}(\xi)\right| \leq c_{1}\left(1+\left|\hat{\zeta}^{2}\right|\right)^{ \pm \frac{\infty}{2}}, \quad\left|A_{d,-}^{ \pm 1}(\xi)\right| \leq c_{2}\left(1+\left|\hat{\zeta}^{2}\right|\right)^{ \pm \frac{\alpha-\infty}{2}},
$$


with constants $c_{1}, c_{2}$ non-depending on $h$,

$$
\hat{\zeta}^{2} \equiv \hbar^{2}\left(\sum_{k=1}^{m-1}\left(e^{-i h \xi_{k}}-1\right)^{2}+\left(e^{-i h\left(\xi_{m}+i \tau\right)}-1\right)^{2}\right), \quad \xi_{m}+i \tau \in \hbar \Pi_{ \pm} .
$$

The number $æ \in \mathbf{R}$ is called an index of periodic factorization.

Such a representation can be constructed effectively and it fully determines a solvability picture for the equation (1).

\section{Conditions for a Unique Solvability}

Some auxiliaries Firstly, for an elliptic symbol $A_{d}(\xi)$ such periodic factorization exists always $[5,8]$.

Secondly, the index $æ$ of periodic factorization determines how much additional conditions for the solution $u_{d}$ or for the right hand side $v_{d}$ we need $[7,9]$.

Thirdly, the equation (1) is uniquely solvable in the discrete half-space $H^{s}\left(D_{d}\right)$ for arbitrary right hand side $v_{d} \in H_{0}^{s-\alpha}\left(D_{d}\right)$ only under the condition

$$
|æ-s|<1 / 2,
$$

Kernel of elliptic digital operator in a discrete half-space

In this paper we consider more complicated case when the condition (2) does not hold. There are two possibilities in this situation, and we consider one case which leads to typical boundary value problems. We use the following result from [7] in a simplest form.

Theorem 1. Let $æ-s=n+\delta, n \in \mathbf{N},|\delta|<1 / 2$. Then the Fourier image for a kernel of the operator $A_{d}$ consists of the following functions

$$
\tilde{u}_{d}(\xi)=\tilde{A}_{d,+}^{-1}(\xi) \sum_{k=0}^{n-1} c_{k}\left(\xi^{\prime}\right) \hat{\zeta}_{m}^{k}
$$

where $c_{k}\left(\xi^{\prime}\right), k=0,1, \cdots, n-1$, are arbitrary functions from $H^{s_{k}}\left(h \mathbf{T}^{m-1}\right), s_{k}=s-\Re+k-1 / 2$.

The a priori estimate

$$
\left\|u_{d}\right\|_{s} \leq a \sum_{k=0}^{n-1}\left[c_{k}\right]_{s_{k}}
$$

holds, where $[\cdot]_{s_{k}}$ denotes a norm in the space $H^{s_{k}}\left(h \mathbf{T}^{m-1}\right)$, and the constant $a$ does not depend on $h$.

\section{Discrete Structures as Approximating Objects.}

Initial Observations for $D=\mathbf{R}^{m}$. Here and below we consider model pseudo-differential operators with symbols $A(\xi)$ satisfying the condition

$$
c_{1}(1+|\xi|)^{\alpha} \leq|A(\xi)| \leq c_{2}(1+|\xi|)^{\alpha} .
$$

Further, the symbol $A_{d}(\xi)$ will be defined in the following way. We take a restriction of $A(\xi)$ on the cube $\hbar \mathbf{T}^{m}$ and periodically extend it onto a whole $\mathbf{R}^{m}$. We consider such operator as an approximate operator for $A$. For arbitrary function $u$ the notation $Q_{h} u$ will denote the same construction. So, to find an approximate discrete solution for the equation

$$
(A u)(x)=v(x), \quad x \in D,
$$

for $D=\mathbf{R}^{m}$ we can use the following discrete equation

$$
A_{d} u_{d}=Q_{h} v .
$$

Its solution is given by the formula

$$
u_{d}(\tilde{x})=\frac{1}{(2 \pi)^{m}} \int_{\hbar \mathbf{T}^{m}} e^{i \tilde{x} \cdot \xi} A^{-1}(\xi) \tilde{v}(\xi) d \xi, \quad \tilde{x} \in h \mathbf{Z}^{m},
$$

so that we do not need to find an approximate solution for an infinite system of linear algebraic equations. For our case we need to apply any kind of cubature formulas for calculating the latter integral and a cubature formula for calculating the Fourier transform $\tilde{v}(\xi)$. For $v \in S\left(\mathbf{R}^{m}\right)$ the discrete solution $u_{d}(\tilde{x})$ tends to $u(\tilde{x})$ very fast under $h \rightarrow 0$ [12]. 


\section{Rate of Approximation.}

Infinite Discrete Half-Space Case. Here we consider the case $æ-s=1+\delta,|\delta|<1 / 2$. According to Theorem 1 , the kernel of the operator $A_{d}$ includes only one arbitrary function so that we need only one additional condition.

The continuous analogue of the discrete boundary value problem

$$
\begin{gathered}
\left(A_{d} u_{d}\right)(\tilde{x})=0, \quad \tilde{x} \in D_{d}, \\
u_{d}\left(\tilde{x}^{\prime}, 0\right)=g_{d}\left(x^{\prime}\right), \quad \tilde{x}^{\prime} \in h \mathbf{Z}^{m-1},
\end{gathered}
$$

is the following

$$
\begin{gathered}
(A u)(x)=0, \quad x \in \mathbf{R}_{+}^{m}, \\
u\left(x^{\prime}, 0\right)=g\left(x^{\prime}\right), \quad x^{\prime} \in \mathbf{R}^{m-1},
\end{gathered}
$$

where $A$ is a pseudo-differential operator with symbol $A(\xi)$. To obtain some comparison between discrete and continuous solutions we will remind how the continuous solution looks. If the index of factorization equals to $æ$ and $æ-s=1+\delta,|\delta|<1 / 2$ then the unique solution for the problem (5),(6) is constructed by the similar formula

$$
\tilde{u}(\xi)=b^{-1}\left(\xi^{\prime}\right) \tilde{g}\left(\xi^{\prime}\right) A_{+}^{-1}\left(\xi^{\prime}, \xi_{m}\right),
$$

where $A_{ \pm}\left(\xi^{\prime}, \xi_{m}\right)$ are elements of factorization of the symbol $A(\xi)$ [5],

$$
b\left(\xi^{\prime}\right)=\int_{-\infty}^{+\infty} A_{+}^{-1}\left(\xi^{\prime}, \xi_{m}\right) d \xi_{m},
$$

assuming that $b\left(\xi^{\prime}\right) \neq 0, \forall \xi^{\prime} \in \mathbf{R}^{m-1}$. Let us note that this is simplest variant of Shapiro-Lopatinskii condition [5].

We have the following discrete solution [8]

$$
\begin{gathered}
\tilde{u}_{d}(\xi)=b_{d}^{-1}\left(\xi^{\prime}\right) \tilde{g}_{d}\left(\xi^{\prime}\right) A_{d,+}^{-1}\left(\xi^{\prime}, \xi_{m}\right), \\
b_{d}\left(\xi^{\prime}\right)=\int_{-\hbar \pi}^{+\hbar \pi} A_{d,+}^{-1}\left(\xi^{\prime}, \xi_{m}\right) d \xi_{m},
\end{gathered}
$$

in which we choose special approximations. We take $g_{d}=Q_{h} g$ and $A_{d, \pm}\left(\xi^{\prime}, \xi_{m}\right)$ we take as restrictions of $A_{ \pm}\left(\xi^{\prime}, \xi_{m}\right)$ on $\hbar \mathbf{T}^{m}$. Then the periodic symbol

$$
A_{d}(\xi)=A_{d,+}\left(\xi^{\prime}, \xi_{m}\right) A_{d,-}\left(\xi^{\prime}, \xi_{m}\right)
$$

satisfies all conditions of periodic factorization with the same index $æ$. Moreover, $\tilde{g}_{d}\left(\xi^{\prime}\right)$ and $A_{d,+}\left(\xi^{\prime}, \xi_{m}\right)$ coincide with $\tilde{g}\left(\xi^{\prime}\right)$ and $A_{+}\left(\xi^{\prime}, \xi_{m}\right)$ respectively on $\hbar \mathbf{T}^{m}$.

Theorem 2. Let $æ>1, s>m / 2, g \in H^{s-1 / 2}\left(\mathbf{R}^{m-1}\right)$. A comparison between solutions of problems (3), (4) and (5), (6) is given in the following way

$$
\left|u(\tilde{x})-u_{d}(\tilde{x})\right| \leq C h^{\infty-1}, \quad \tilde{x} \in h \mathbf{Z}^{m} .
$$

Proof. We need to compare two integrals:

$$
u(\tilde{x})=\frac{1}{(2 \pi)^{m}} \int_{\mathbf{R}^{m}} e^{i \tilde{x} \cdot \xi} b^{-1}\left(\xi^{\prime}\right) \tilde{g}\left(\xi^{\prime}\right) A_{+}^{-1}\left(\xi^{\prime}, \xi_{m}\right) d \xi
$$

and

$$
u_{d}(\tilde{x})=\frac{1}{(2 \pi)^{m}} \int_{\hbar \mathbf{T}^{m}} e^{i \tilde{x} \cdot \xi} b_{d}^{-1}\left(\xi^{\prime}\right) \tilde{g}\left(\xi^{\prime}\right) A_{+}^{-1}\left(\xi^{\prime}, \xi_{m}\right) d \xi
$$

for $\tilde{x} \in h \mathbf{Z}^{m}$. 
Thus, we have

$$
\begin{gathered}
u(\tilde{x})-u_{d}(\tilde{x})=\frac{1}{(2 \pi)^{m}} \int_{\hbar \mathbf{T}^{m}} e^{i \tilde{x} \cdot \xi}\left(b^{-1}(\xi)-b_{d}^{-1}\left(\xi^{\prime}\right)\right) \tilde{g}\left(\xi^{\prime}\right) A_{+}^{-1}\left(\xi^{\prime}, \xi_{m}\right) d \xi+ \\
\frac{1}{(2 \pi)^{m}} \int_{\mathbf{R}^{m} \backslash \hbar \mathbf{T}^{m}} e^{i \tilde{x} \cdot \xi} b^{-1}\left(\xi^{\prime}\right) \tilde{g}\left(\xi^{\prime}\right) A_{+}^{-1}\left(\xi^{\prime}, \xi_{m}\right) d x i i,
\end{gathered}
$$

because the functions $\tilde{g}, \tilde{g}_{d}$ and $A_{+}, A_{d,+}$ coincide in $\hbar \mathbf{T}^{m}$.

Now we estimate the second integral.

$$
\begin{gathered}
\int_{\mathbf{R}^{m} \backslash \hbar \mathbf{T}^{m}} e^{i \tilde{x} \cdot \xi} b^{-1}\left(\xi^{\prime}\right) \tilde{g}\left(\xi^{\prime}\right) A_{+}^{-1}\left(\xi^{\prime}, \xi_{m}\right) d \xi\left|\leq \operatorname{const} \int_{\mathbf{R}^{m} \backslash \hbar \mathbf{T}^{m}}\right| \tilde{g}\left(\xi^{\prime}\right)|| A_{+}^{-1}\left(\xi^{\prime}, \xi_{m}\right) \mid d \xi \leq \\
\text { const } \int_{\mathbf{R}^{m-1} \backslash \hbar \mathbf{T}^{m-1}}\left|\tilde{g}\left(\xi^{\prime}\right)\right|\left(\int_{-\infty}^{-\hbar \pi}+\int_{\hbar \pi}^{+\infty}\right)\left|A_{+}^{-1}\left(\xi^{\prime}, \xi_{m}\right)\right| d \xi_{m} d \xi^{\prime} .
\end{gathered}
$$

Further, we estimate

$$
\begin{gathered}
\left(\int_{-\infty}^{-\hbar \pi}+\int_{\hbar \pi}^{+\infty}\right)\left|A_{+}^{-1}\left(\xi^{\prime}, \xi_{m}\right)\right| d \xi_{m} \leq \mathrm{const} \int_{\hbar \pi}^{+\infty}\left(1+\left|\xi^{\prime}\right|+\left|\xi_{m}\right|\right)^{-\infty} d \xi_{m}= \\
\frac{\text { const }}{æ-1}\left(1+\left|\xi^{\prime}\right|+\hbar \pi\right)^{1-æ} \leq c_{6} h^{æ-1} .
\end{gathered}
$$

Now by Cauchy-Schwartz inequality we have

$$
\begin{aligned}
& \int_{\mathbf{R}^{m-1} \backslash \hbar \mathbf{T}^{m-1}}\left|\tilde{g}\left(\xi^{\prime}\right)\right| d \xi^{\prime} \leq \\
& \left(\int_{\mathbf{R}^{m-1} \backslash \hbar \mathbf{T}^{m-1}}\left|\tilde{g}\left(\xi^{\prime}\right)\right|^{2}\left(1+\left|\xi^{\prime}\right|\right)^{2 s-1} d \xi^{\prime}\right)^{1 / 2}\left(\int_{\mathbf{R}^{m-1} \backslash \hbar \mathbf{T}^{m-1}}\left(1+\left|\xi^{\prime}\right|\right)^{-2 s+1} d \xi^{\prime}\right)^{1 / 2} .
\end{aligned}
$$

Since $g \in H^{s-1 / 2}\left(\mathbf{R}^{m-1}\right)[5]$ the first factor is less than $[g]_{s-1 / 2}$ and the second one tends to zero if $s>m / 2$. For the first integral we use the estimate

$$
\left|b^{-1}\left(\xi^{\prime}\right)-b_{d}^{-1}\left(\xi^{\prime}\right)\right| \leq \text { const } \cdot h^{æ-1}
$$

(see [15]).

Finally,

$$
\begin{gathered}
\left|\frac{1}{(2 \pi)^{m}} \int_{\hbar \mathbf{T}^{m}} e^{i \tilde{x} \cdot \xi}\left(b^{-1}(\xi)-b_{d}^{-1}\left(\xi^{\prime}\right)\right) \tilde{g}\left(\xi^{\prime}\right) A_{+}^{-1}\left(\xi^{\prime}, \xi_{m}\right) d \xi\right| \leq \\
\text { const } \cdot h^{æ-1} \int_{\hbar \mathbf{T}^{m}}\left|\tilde{g}\left(\xi^{\prime}\right)\right|\left|A_{+}^{-1}\left(\xi^{\prime}, \xi_{m}\right)\right| d \xi \leq \text { const } \cdot h^{æ-1} \int_{\hbar \mathbf{T}^{m-1}} \frac{\left|\tilde{g}\left(\xi^{\prime}\right)\right|}{\left(1+\left|\xi^{\prime}\right|\right)^{æ-1}} d \xi^{\prime}
\end{gathered}
$$

and further as above using Cauchy-Schwartz inequality.

Finite Truncation. To obtain finite object for calculation we can apply an arbitrary cubature formula for the integral (7) and to approximately find its value in nodal points. 


\section{Conclusion}

Here only model operators in a half-space were considered. We hope that these ideas and technique will be useful for more complicated situations in which both an operator depends on a spatial variable or a domain is not a half-space.

\section{Acknowledgements}

This work was supported by the State contract of the Russian Ministry of Education and Science (contract No FZWG-2020-0029).

\section{References}

1 Strang, G., \& Fix, G. (2008). An analysis of the finite element method. Cambridge Wellesley-Cambridge Press, 2 edition.

2 Samarskii, A.A. (2001). The theory of difference schemes. CRC Press Boca Raton.

3 Ryaben'kii, V.S. (2002). Method of difference potentials and its applications. Springer-Verlag, BerlinHeidelberg.

4 Hsiao, G., \& Wendland, W.(2008). Boundary integral equations. Springer-Verlag, Berlin-Heidelberg.

5 Eskin, G. (1981). Boundary value problems for elliptic pseudodifferential equations. AMS Providence.

6 Vasilev, A.V., \& Vasilev, V.B. (2015). Periodic Riemann problem and discrete convolution equations. Differ. Equ., 51(5), 652-660.

7 Vasilyev, A.V., \& Vasilyev, V.B. (2018). Pseudo-differential operators and equations in a discrete halfspace. Math. Model. Anal., 23(3), 492-506.

8 Vasilyev, A.V., \& Vasilyev, V.B. (2018). On some discrete boundary value problems in canonical domains. Differential and Difference Equations and Applications. ICDDEA, Amadora, Portugal, Springer Proc. Math. \& Stat., 230, 569-579.

9 Vasilyev, A.V., \& Vasilyev, V.B. (2018). On some discrete potential like operators. Tatra Mt.Math. Publ., 71, 195-212.

10 Vasilyev, V.B.(2017). Discreteness, periodicity, holomorphy and factorization. Integral Methods in Science and Engineering. V.1, Theoretical Technique, 315-324.

11 Vasilyev, A., \& Vasilyev, V. (2019). Digital operators, discrete equations and error estimates. Numerical Mathematics and Advanced Applications ENUMATH LNCSE, 126, 983-991.

12 Vasilyev, V.B. (2019). Digital approximations for pseudo-differential equations and error estimates. Numerical Methods and Applications. NMA LNCS, 11189, 483-490.

13 Vasilyev, V.B. (2019). On a digital Version of pseudo-differential operators and its applications. Finite Difference Methods. Theory and Applications. FDM LNCS, 11386, 596-603.

14 Vasilyev, V.(2017).The periodic Cauchy kernel, the periodic Bochner kernel, and discrete pseudo-differential operators. AIP Conf. Proc., 1863, 140014.

15 Tarasova, O.A., \& Vasilyev, V.B. (2019). To the theory of discrete boundary value problems. 4open, 2, $1-7$. 


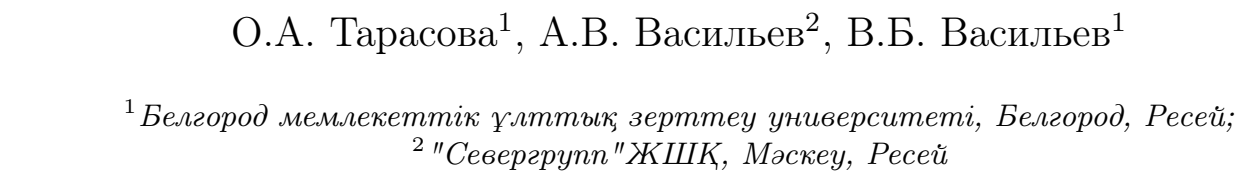

\title{
Эллиптикалық псевдодифференциалды теңдеулердің дискретті шешімдері туралы
}

\begin{abstract}
Соболев-Слободецкий кеңістігіндегі Дирихле шекаралық жағдайы бар жартылай кеңістіктегі эллиптикалық псевдодифференциалды теңдеудің қарапайым шекаралық есебінің дискретті аналогы қарастырылған. Эллиптикалық псевдодифференциалды теңдеулер үшін дискретті жиек есептері теориясына сүйене отырып, бір модельдік шекаралық есеп үшін дискретті және үздіксіз шешімдер арасындағы салыстыру берілген.
\end{abstract}

Kiлm сөздер: дискретті псевдодифференциалды оператор, дискретті шешім, дискретті шекаралық есеп, жуықтау реті.

\section{О.А. Тарасова ${ }^{1}$, А.В. Васильев ${ }^{2}$, В.Б. Васильев ${ }^{1}$}

${ }^{1}$ Белгородский государственный националъный исследователъский университет, Белгород, Россия; ${ }^{2} \mathrm{OOO}$ «евергрупп», Москва, Россия

\section{О дискретных решениях эллиптических псевдодифференциальных уравнений}

\footnotetext{
Рассмотрен дискретный аналог простейшей краевой задачи для эллиптического псевдодифференциального уравнения в полупространстве с граничным условием Дирихле в пространстве СоболеваСлободецкого. Основываясь на теории дискретных краевых задач для эллиптических псевдодифференциальных уравнений, дано сравнение между дискретными и непрерывными решениями для одной модельной краевой задачи.

Ключевые слова: дискретный псевдодифференциальный оператор, дискретное решение, дискретная краевая задача, порядок аппроксимации.
} 
DOI $10.31489 / 2021 \mathrm{M} 3 / 124-130$

UDC 510.67

\author{
A.R. Yeshkeyev ${ }^{*}$, A.K. Issayeva, N.K. Shamatayeva \\ Karagandy university of the name of academician E.A. Buketov, Karaganda, Kazakhstan \\ (E-mail: aibat.kz@gmail.com, isaaiga13@gmail.com,naz.kz85@mail.ru)
}

\title{
On atomic and algebraically prime models obtained by closure of definable sets
}

\begin{abstract}
This article discusses the properties of atomic and prime models obtained with the some closure operator given on definable subsets of the semantic model some fixed Jonsson theory. The main result is to obtain the equivalence of the thus defined atomic and prime models, and this coincidence follows the assumption that there is some model with nice-defined properties.
\end{abstract}

Keywords: Jonsson theory, semantic model, prime model, atomic model, algebraically prime model, pregeometry, definable subset.

The paper considered the syntactic and semantic characteristics of prime and atomic models [1]. A. Robinson defined a natural generalization of a prime model, and he called such a model an algebraically prime model. In work [2] the corresponding notions of atomicity and their connection with an algebraically prime model were systematically studied. We propose several new types of atomic models and refine these concepts for algebraically prime models within the framework of these types of atomic. We have previously obtained some results in connection with these new concepts in works [3-6].

With these concepts of types of atomic and primary models we can work in fixed classes of Jonsson theories, depending on the conditions of the problem under consideration. In work [7] generalizations of the concept of isomorphic embedding were considered and within the framework of this definition results were obtained connecting the concepts of atomic and algebraically prime within the framework of this generalization. Thus, this work is a synthesis of new results obtained using ideas and concepts of works [3-6] and [7]. In [8-13] some new directions related to the study of Jonsson theories and their companions were considered and studied. The results of this work can be useful for studying the properties of countable models related to the above topics from the list of papers [3-6], [8-13].

Remind some concepts from [7].

Let $\alpha \leq \omega, \mathfrak{A}, \mathfrak{B}$ are models first order of $L$. Then the mapping $f: \mathfrak{A} \rightarrow \mathfrak{B}$ is called $\alpha$ an embedding if for any formula $\varphi(\bar{x}) \in \Pi_{\alpha}$ and any tuple $\bar{a} \in A$ from the fact that $\mathfrak{A} \models \varphi(\bar{a})$, it follows $\mathfrak{B} \models \varphi(f(\bar{a}))$. A model $\mathfrak{A}$ of the theory $T$ is called $\alpha$-algebraically prime if $\mathfrak{A} \alpha$-embeddable into any model of the theory $T$.

From the above definitions it is easy to see that the concepts of an algebraically prime model and a prime model are obtained from the concept of an $\alpha$-algebraically prime models for $\alpha=0$ and $\alpha=\omega$ respectively. If $\Gamma$ is a set of formulas, then we put $\Gamma^{*} \rightleftharpoons\{\neg \varphi / \varphi \in \Gamma\}$. If $\bar{a}=\left\langle a_{0} \ldots a_{n}\right\rangle, \mathfrak{A}$ is a model, then $\bar{a} \in \mathfrak{A}$ means that $a_{i} \in A, i<n$. A type $p$ is called a $\Gamma$-type if $p \subseteq \Gamma$. Further, $t_{\Gamma}^{\mathfrak{A}}(\bar{a}) \rightleftharpoons\{\varphi(\bar{x}) / \varphi(\bar{x}) \in L, \mathfrak{A} \models \varphi(\bar{a})\}$ is called a $\Gamma$-type $\bar{a}$ in $\mathfrak{A}$. $\Gamma_{2}$-type $p$ is called a $\Gamma_{1}$-the main type if there is a $\Gamma_{1}$ is formula $\varphi(\bar{x})$ such that $T \models \forall(\bar{x})(\varphi(\bar{x}) \rightarrow \psi(\bar{x}))$ forall $\psi(\bar{x}) \in p$. In this case $\varphi(\bar{x})$ is said to generate $p$.

It is easy to see the following fact. Let $\mathfrak{A}$ is a model of the theory $T$, then $\mathfrak{A}$ is $\left(\Gamma_{1}, \Gamma_{2}\right)$-atomic model $T$ if and only if for any $\bar{a} \in A$ there is such a formula $\varphi(\bar{x}) \in \Gamma_{1}$, which is true:

a) $\mathfrak{A} \models \varphi(\bar{x})$;

b) $\varphi(\bar{x})$ generates $t_{\Gamma \cup \Gamma^{*}}^{\mathfrak{A}}(\bar{a})$.

Similarly, if $\mathfrak{A} \models T$, then $\mathfrak{A}$ is weakly $\left(\Gamma_{1}, \Gamma_{2}\right)$ atomic model of $T$ if and only if for any $\bar{a} \in A$ there is a formula $\varphi(\bar{x}) \in \Gamma_{1}$ that is true:

a) $\mathfrak{A} \models \varphi(\bar{x})$;

b) $\varphi(\bar{x})$ generates $t_{\Gamma_{2}}^{\mathfrak{A}}(\bar{a})$.

In papers [3-6] the properties of atomic models were considered with the help of the closure operator specifying some pregeometry on subsets of the semantic model of a fixed Jonsson theory.

\footnotetext{
${ }^{*}$ Corresponding author.

E-mail: aibat.kz@gmail.com
} 
Let $\mathrm{cl}$ is some closure operator defining a pregeometry over $C$ (for example $\mathrm{cl}=\mathrm{acl}$ or $\mathrm{cl}=\mathrm{dcl}$ ). It is clear that such operator is a special case of the closure operator and its example is a closure operator defined on any linear space as a linear shell. Further, the concepts under consideration are produced within the framework of a perfect Jonsson theory and if the contrary is not specified then the considered Jonsson theories are assumed to be complete for existential sentences.

Let us give definitions related to the atomic and prime model considered in this theory.

Definition 1. A set $A$ will be called the $\left(\Gamma_{1}, \Gamma_{2}\right)$-cl atomic in $T$ if:

1) $\forall \bar{a} \in A, \exists \varphi(\bar{x}) \in \Gamma_{1}$ such that $\mathfrak{A} \models \varphi(\bar{a})$;

2) $\varphi(\bar{x})$ generates $t_{\Gamma \cup \Gamma^{*}}^{\mathfrak{A}}(\bar{a})$;

3) $\operatorname{cl}(A)=M, M \in E_{T}$, where $E_{T}$ class of existentially closed models of the theory $T$;

and obtained model $M$ is said to be the $\left(\Gamma_{1}, \Gamma_{2}\right)$-cl atomic model of the theory $T$.

Definition 2. A set $A$ is said to be weakly the $\left(\Gamma_{1}, \Gamma_{2}\right)$-cl atomic in $T$, if $\forall \bar{a} \in A \exists \varphi(\bar{x}) \in \Gamma_{1}$ such that:

1) $\varphi(\bar{x}) \cup T$ is consistent;

2) $\varphi(\bar{x})$ generates $t_{\Gamma_{2} \cup \Gamma_{2}^{*}}^{\mathfrak{A}}(\bar{a})$;

3) $\operatorname{cl}(A)=M, M \in E_{T}$, where $E_{T}$ class of existentially closed models of the theory $T$; And obtained model $M$ is said to be weakly $\left(\Gamma_{1}, \Gamma_{2}\right)$-cl atomic model of the theory $T$.

Definition 3. A set $A$ is said to be almost-weakly $\left(\Gamma_{1}, \Gamma_{2}\right)$-cl atomic in $T$ if for any $\bar{a} \in A$ there exists a formula $\varphi(\bar{x}) \in \Gamma_{1}$ such that:

1) $\varphi(\bar{x}) \cup T$ is consistent;

2) $\varphi(\bar{x})$ generates $t_{\Gamma_{2}}^{\mathfrak{A}}(\bar{a})$;

3) $\operatorname{cl}(A)=M, M \in E_{T}$, where $E_{T}$ is the class of existentially closed models of theory $T$; And obtained model $M$ is said to be almost-weakly $\left(\Gamma_{1}, \Gamma_{2}\right)$-cl atomic model of the theory $T$.

Definition 4. A set $A$ is said to be the $\left(\Gamma_{1}, \Gamma_{2}\right)$-cl algebraically prime of the theory $T$, if $c l(A)=M, M$ is $\left(\Gamma_{1}, \Gamma_{2}\right)$-cl atomic model of the theory $T, M \in E_{T} \cap A P_{T}$, where $A P_{T} \cap E_{T} \neq \varnothing$ and obtained model $M$ is said to be $\left(\Gamma_{1}, \Gamma_{2}\right)$-cl algebraically prime of the theory $T$.

Definition 5. A set $A$ is said to be almost $\left(\Gamma_{1}, \Gamma_{2}\right)$-cl algebraically prime of the theory $T$, if $\operatorname{cl}(A)=M, M$ is been almost $\left(\Gamma_{1}, \Gamma_{2}\right)$-cl atomic model of the theory $T, M \in E_{T} \cap A P_{T}$, where $A P_{T} \cap E_{T} \neq 0$ and obtained model $M$ is said to be almost the $\left(\Gamma_{1}, \Gamma_{2}\right)$-cl algebraically prime of the theory $T$.

Definition 6 . A set $A$ is said to be almost-weakly $\left(\Gamma_{1}, \Gamma_{2}\right)$-cl algebraically prime of theory $T$, if $c l(A)=M$, $M$ is been almost-weakly $\left(\Gamma_{1}, \Gamma_{2}\right)$-cl atomic model of the theory $T, M \in E_{T} \cap A P_{T}$, where $A P_{T} \cap E_{T} \neq 0$ and obtained model $M$ is said to be almost-weakly $\left(\Gamma_{1}, \Gamma_{2}\right)$-cl algebraically prime of the theory $T$.

For the convenience of expression

" $\mathfrak{A}$ is $\left(\Gamma_{1}, \Gamma_{2}\right)$-cl atomic model of the theory $T$ ";

" $\mathfrak{A}$ is weakly $\left(\Gamma_{1}, \Gamma_{2}\right)$-cl atomic model of theory $T$ ";

" $\mathfrak{A}$ is an almost $\left(\Gamma_{1}, \Gamma_{2}\right)$-cl atomic model of theory $T$ ";

" $\mathfrak{A}$ is an almost-weakly $\left(\Gamma_{1}, \Gamma_{2}\right)$-cl atomic model of theory $T$ "; and denote by (1), (2), (3), (4), respectively.

Lemma 1.

1. If $\left(\Gamma_{2}=\Gamma_{2}^{*}\right)$, then (1) $\Leftrightarrow(2),(3) \Leftrightarrow(4)$.

2. If $\left(\Gamma_{1}^{*} \subset \Gamma_{2}\right)$, then $(1) \Leftrightarrow(3),(2) \Leftrightarrow(4)$.

3. If $\left(\Gamma_{2} \cup \Gamma_{2}^{*}\right) \subset \Gamma_{3}$, then if

a) $\mathfrak{A}$ is weakly $\left(\Gamma_{1}, \Gamma_{2}\right)$-cl atomic model of the theory $T$, then it is true (1);

b) $\mathfrak{A}$ is an almost-weakly $\left(\Gamma_{1}, \Gamma_{2}\right)$-cl atomic model of the theory $T$, then it is true $(3)$.

4. If $\left(\Gamma_{1}^{*} \subset \Gamma_{2} \subset \Gamma_{2}^{*}\right)$, then $(1) \Leftrightarrow(2) \Leftrightarrow(3) \Leftrightarrow(4)$.

5. If $\left(\Gamma_{1}=\Gamma_{2}=\Gamma_{2}^{*}\right)$, then $(1) \Leftrightarrow(2) \Leftrightarrow(3) \Leftrightarrow(4)$.

6. If $\left(\Gamma_{1} \subset \Gamma_{1}^{\prime}\right),\left(\Gamma_{2} \subset \Gamma_{2}^{\prime}\right)$, then $\tau-\left(\Gamma_{1}, \Gamma_{2}^{\prime}\right)$-cl atomic model of the theory $T \Rightarrow \tau-\left(\Gamma_{1}^{\prime}, \Gamma_{2}\right)$-cl atomic model of the theory $T$, where $\tau \in\{\emptyset$, weakly, almost, almost-weakly $\}$.

Proof. The proof follows easily from the definition.

Lemma 2. If $T$ is complete for $\exists \Gamma_{2}$ (i.e., if $\psi(\bar{x}) \cup T$ consistent and $\psi(\bar{x}) \in \Gamma_{2}$, then it is true that $T \models \exists \bar{x} \psi(\bar{x})$ ) and $\left(\Gamma_{1} \cup \Gamma_{1}^{*}\right) \subset \Gamma_{2}$ then it is true $(1) \Leftrightarrow(2) \Leftrightarrow(3) \Leftrightarrow(4)$.

Proof. Since $\Gamma_{1}^{*} \subset \Gamma_{2}$, then, by part 2) of Lemma 1, it suffices to show (2) $\Leftrightarrow$ (1). Let (2) $\bar{a} \in A, \mathfrak{A} \models \psi(\bar{a})$, $\psi(\bar{x}) \in \Gamma_{1}, \psi(\bar{x})$ generates $t_{\Gamma_{2}}^{\mathfrak{A}}(\bar{a})$.

Let $\neg \psi(\bar{x}) \in \Gamma_{2}^{*}$ and $\mathfrak{A} \models \neg \psi(\bar{a})$. Let us show that $T \models \psi(\bar{x}) \rightarrow \neg \varphi(\bar{x})$. 
Suppose the opposite: $T \cup\{\psi(\bar{x}) \wedge \varphi(\bar{x})\}$ consistent. Since $T$ is complete for $\exists \Gamma_{2}$, then $T \models \exists \bar{x}(\psi(\bar{x}) \wedge \varphi(\bar{x}))$. So there is $\bar{b} \in A$ such that $\mathfrak{A} \models \psi(\bar{b}) \wedge \varphi(\bar{b})$. Let $\theta(\bar{x}) \in \Gamma_{1}, \mathfrak{A} \models \theta(\bar{b})$ and $\theta(\bar{x})$ generates $t_{\Gamma_{2}}^{\mathfrak{A}}(\bar{b})$ by $(2)$. Note that $T \models \theta(\bar{x}) \wedge \varphi(\bar{x})(1)$ as well as $T \vdash \psi(\bar{x}) \wedge \neg \theta(\bar{x})(2)$.

Since $\neg \theta(\bar{x}) \in \Gamma_{1}^{*} \subset \Gamma_{2}$ it follows from $(2)$ that $\neg \theta(\bar{x}) \notin t_{\Gamma_{2}}^{\mathfrak{A}}(\bar{a})$, i.e., $\mathfrak{A}=\theta(\bar{a})$. According to (1), in this case, $\mathfrak{A} \models \varphi(\bar{a})$ must be true. Contradiction. Recall that $\triangle_{\kappa} \rightleftharpoons \Sigma_{\kappa} \cap \Pi_{\kappa}$.

Corollary 3.

1) If $\Gamma_{1}=\Gamma_{2}=\Sigma_{\omega}$, then (1) $\Leftrightarrow(2) \Leftrightarrow(3) \Leftrightarrow(4)$.

2) For any $\alpha \leq \beta \leq \omega$, if $\Gamma_{1}=\triangle, \Gamma_{2}=\Sigma, T$ is complete for $\Sigma$, then it is true $(1) \Leftrightarrow(2) \Leftrightarrow(3) \Leftrightarrow(4)$.

Proof. 1) follows from part 5) of Lemma 1;

2) from Lemma 2.

If $\Gamma \in\{\Sigma ; \Pi\}$, then $\Gamma(\mathfrak{A}, \bar{a})_{\bar{a} \in A}$ denotes the set of sentences of the form $\Gamma$ in the language $L$ that are true on $(\mathfrak{A}, \bar{a})_{\bar{a} \in A}$.

Lemma 4. If $\mathfrak{A}$ is a model of $T$, then following conditions are equivalent:

1) $\mathfrak{A}$ is $\left(\Gamma_{1}, \Gamma_{2}\right)$-cl algebraically prime of the theory $T$.

2) Every model $T$ can be enriched to the model $T \cup \Pi(\mathfrak{A}, \bar{a})_{\bar{a} \in A}$.

3) Every model $T$ can be enriched to the model $T \cup \Sigma(\mathfrak{A}, \bar{a})_{\bar{a} \in A}$.

Proof 3$) \Leftrightarrow 2) \Leftrightarrow 1$ ) obviously.

Let's show 1) $\Leftrightarrow 3)$.

Let $f: \mathfrak{A} \rightarrow \mathfrak{B}$ be isomorphic embedding $\bar{a} \in A, \varphi(\bar{x}) \in \Sigma_{1}: \mathfrak{A} \models \varphi(\bar{a}), \varphi(\bar{x})=\exists \bar{y} \psi(\bar{y}, \bar{x}), \psi(\bar{y}, \bar{x}) \in \Pi$, $\overline{a_{1}} \in A, \mathfrak{A}=\psi\left(\overline{a_{1}}, \bar{a}\right)$. Then $\mathfrak{B} \models \psi\left(f\left(\overline{a_{1}}\right), f(\bar{a})\right)$ due to the fact $f$ is an isomorphic embedding.

Further, we have $\mathfrak{B}=\exists y \psi(\bar{y}, f(\bar{a}))$ i.e., $\mathfrak{B}=\varphi(f(\bar{a}))$. Hence $(\mathfrak{B}, f(\bar{a}))_{\bar{a} \in A}$ are the model of $T \cup \Sigma_{1}(\mathfrak{A}, \bar{a})_{\bar{a} \in A}$

Definition 7. Let $\Phi\left(x_{1} \ldots x_{\kappa}\right)$ be some set of formulas of the language $L$ from variables $x_{1} \ldots x_{\kappa}$. We say that $\Gamma_{1}$ locally omitted $\Phi$ if for any formula consistent with $T$ formulas $\varphi\left(x_{1} \ldots x_{\kappa}\right) \in \Gamma_{1}$ there is such a formula $\theta\left(x_{1} \ldots x_{\kappa}\right) \in \Phi$ such that $\varphi \wedge \neg \theta$ consistent with $T$.

Theorem 5. Let $T$ be $\Pi_{2}$-axiomatizable consistent theory of a countable language $L$ and for any $n<\omega$ let $\Phi\left(x_{1} \ldots x_{m_{n}}\right)$ be the set of the $\Pi_{1}$ are formulas of $m_{n}$ variables. If $T \Sigma_{1}$ locally omitted every $\Phi^{n}, n<\omega$, then $T$ has a countable model which omitted every set $\Phi^{n}, n<\omega$.

The proof can be taken from [15].

Theorem 6 . Let $T$ be a perfect Jonsson theory complete for $\Pi_{2}$ sentences. Then every $(\Sigma, \Sigma)$-cl algebraically prime model of theory $T$ is an almost-weakly $(\Sigma, \Sigma)$-cl atomic model of the theory $T$.

Proof. Let $\mathfrak{A}$ be the $(\Sigma, \Sigma)$-cl algebraically prime model of theory $T$. Suppose there is a $\bar{a} \in A$, such that $t_{\Sigma}^{\mathfrak{A}}(\bar{a})$ is not be the $\Sigma_{2}$ is principle type. Since $\Sigma_{1} \subset \Pi_{2}$ then by Theorem 5 , there exists a model $\mathfrak{B}$ of the theory $T$, which omits $t_{\Sigma_{1}}^{\mathfrak{A}}(\bar{a})$. Let $f: \mathfrak{A} \rightarrow \mathfrak{B}$ be an embedding. Then by Lemma 4 we have $t_{\Sigma_{1}}^{\mathfrak{A}}(\bar{a}) \subseteq t_{\Sigma_{1}}^{\mathfrak{B}}(f(\bar{a}))$. It follows that $f(\bar{a})$ implements $t_{\Sigma_{1}}^{\mathfrak{A}}(\bar{a})$ to $\mathfrak{B}$. This contradicts Theorem 5 .

Definition 8. Let $t_{1}$ be the $\Gamma_{1}$-type, $t_{2}$ be the $\Gamma_{2}$-type, then they say that $t_{1}$ and $t_{2} T$-equivalent if $T \cup t_{1} \vdash t_{2}$ $\& T \cup t_{2} \vdash t_{1}$. In this case, write $t_{1} \sim_{T} t_{2}$. The following is known next lemma.

Lemma \%. Let $T$ be perfect Jonsson theory complete for $\Pi_{2}$ sentences and $\mathfrak{A} \models T$, then there is a model $\mathfrak{B}$, such that:

1) $\mathfrak{B} \models T$;

2) $\mathfrak{A}$ is isomorphically embeddable in $\mathfrak{B}$;

3) for any $\bar{b} \in B t_{\Sigma_{1}}^{\mathfrak{B}}(\bar{b}) \sim_{T} t_{\Sigma_{2}}^{\mathfrak{B}}(\bar{b})$.

Proof. The proof follows from [14] and the above definitions.

Theorem 8. Let $T$ be the perfect Jonsson theory complete for $\Pi_{2}$ sentences. Then every $(\Sigma, \Sigma)$-cl algebraically prime model of the theory $T$ is an almost-weakly $(\Sigma, \Sigma)$-cl atomic model of the theory $T$.

Proof. Firstly, we prove the following fact (F). If $\varphi(\bar{x}) \in \Sigma_{1}$ and $\varphi(\bar{x}) \cup T$ is consistent, then there is a formula $\psi(\bar{x}) \in \Sigma_{1}$ such that $T \cup \psi(\bar{x})$ is consistent and $T \models \psi(\bar{x}) \rightarrow \varphi(\bar{x})$. Indeed, let $\varphi(\bar{x}) \in \Sigma_{1}$ and $\varphi(\bar{x}) \cup T$ are consistent. Since that $T$ is complete for $\Pi_{2}$ sentences we have $T \vdash \exists \bar{x} \varphi(\bar{x})$. Since $T \Pi_{2}$ is axiomatizable, then by Lemma 7 there exists a model $\mathfrak{B}=T$, such that for any $\bar{b} \in B$ is holds

$$
t_{\Sigma_{1}}^{\mathfrak{B}}(\bar{b}) \sim_{T} t_{\Sigma_{2}}^{\mathfrak{B}}(\bar{b})
$$

Let $\bar{b} \in B$ such that $\mathfrak{B}=\varphi(\bar{b})$. Due to $\left(^{*}\right)$ and the closedness concerning the conjunction of the type $t_{\Sigma_{1}}^{\mathfrak{B}}(\bar{b})$ there is a formula $\psi(\bar{x}) \in t_{\Sigma_{1}}^{\mathfrak{B}}(\bar{b})$, such that $T \vdash \psi(\bar{x}) \rightarrow \varphi(\bar{x})$. Fact $(\mathrm{F})$ is proved.

Further $\mathfrak{A}$ be $(\Sigma, \Sigma)$-cl algebraically prime model of theory $T, \bar{a} \in A, t=t_{\Sigma}^{\mathfrak{A}}(\bar{a})$. By Theorem 6 A-almostweakly $(\Sigma, \Sigma)$-cl atomic model of theory $T$. Therefore, there is a formula $\varphi(\bar{x}) \in \Sigma$ consistent with $T$, which generates $t_{\Sigma}^{\mathfrak{A}}(\bar{a})$. According to $(\mathrm{F})$, there exists a formula $\psi(\bar{x}) \in \Sigma$ consistent with $T$, for which the following 
holds: $T \vdash \psi(\bar{x}) \rightarrow \varphi(\bar{x})$. Obviously $\psi(\bar{x})$ generates $t_{\Sigma}^{\mathfrak{A}}(\bar{a})$. Due to the arbitrariness $\bar{a} \in A$ a model $\mathfrak{A}$ is almostweakly $(\Sigma, \Sigma)$-cl atomic model of the theory $T$.

Remark. Let $\alpha, \beta \leq \omega, \bar{x}^{\alpha} \rightleftharpoons<x_{i}: 1 \leq i \leq 1+\alpha>, \bar{a}^{\alpha}=<a_{i}: 1 \leq i \leq 1+\alpha>$.

Definition 9. 1) $\alpha$-type is called any set of formulas consistent with $T$, the free variables of which are found in $\bar{x}$;

2) $\omega$-type $\rho$ is called $\Gamma$ - $\omega$-type, if $\rho \subseteq \Gamma$;

3) $\Gamma$ - $\omega$-type $\rho$ is called $\Gamma_{1}$-principle type if there exists such a sequence $\left\langle\psi_{n}\left(\bar{x}^{n}\right): 1 \leq n<\omega\right\rangle \Gamma_{1}$-formulas, such that:

a) $T \cup \psi_{n}\left(\bar{x}^{n}\right)$ is consistent, $1 \leq n<\omega$;

b) $\psi_{n}\left(\bar{x}^{n}\right)$ generates $\rho \uparrow \bar{x}^{n}$, where $\rho \uparrow \bar{x}^{n}$ is set of formulas from $\rho$, the free variables of which are among $\left(x_{1}, \ldots, x_{n}\right), 1 \leq n<\omega$;

c) $T \vdash \psi_{n}\left(\bar{x}^{n}\right) \leftrightarrow \exists \bar{x}_{n+1} \psi_{n+1}\left(\bar{x}^{n+1}\right), 1 \leq n<\omega$.

Definition 10. A model $\mathfrak{A}$ of the theory $T$ is said to be the fine almost-weakly $\left(\Gamma_{1}, \Gamma_{2}\right)$-cl atomic model of $T$ if each tuple of $\omega$ elements $\mathfrak{A}$ implements $\Gamma_{1}$-principle type $\Gamma_{2} \omega$-type.

Lemma 9. Let $\mathfrak{A}$ be a countable model of the perfect Jonsson theory $T, A=\bar{a}^{\omega}=<a_{1} \ldots, a_{n}, \ldots>$ implements $(\Sigma, \Sigma)$ - $\omega$-type. $\mathfrak{B} \models T, \mathfrak{B}$ is the isomorphically embeddable in $\mathfrak{A}$. Then $\mathfrak{B}$ is a fine almost-weakly $(\Sigma, \Sigma)$-cl atomic model of $T$.

Proof. Let $\bar{b}^{\omega}=<b_{1}, \ldots, b_{n}, \ldots>$ be an arbitrary tuple of $\omega$-elements $\mathfrak{B}$. Such that $\mathfrak{B}$ is the isomorphically embeddable in $\mathfrak{A}$, then $b_{k}=a_{i_{k}}$ for some $1 \leq k<\omega$.

Let $n_{k} \rightleftharpoons i j: 1 \leq j \leq k$,

$Z_{k}=1,2,3, . ., n_{k} \backslash i j: 1 \leq j \leq k ; \bar{y}^{k}=<y_{1}, \ldots, y_{k}>$.

Such that $\bar{a}^{\omega}$ implements the $\Sigma$-principal type $\Sigma$ - $\omega$-type, then there exists a sequence of $\Sigma$-formulas $\left\langle\psi_{n}\left(\bar{x}^{n}\right)\right.$ : $1 \leq n<\omega\rangle$, for which the following is true:

1) $\psi_{n}\left(\bar{x}^{n}\right) \cup T$ is consistent, $1 \leq n<\omega$;

2) $\psi_{n}\left(\bar{x}^{n}\right)$ generates $t_{\Sigma}^{\mathfrak{A}}\left(\bar{a}^{n}\right) 1 \leq n<\omega$;

3) $T \vdash \psi_{n}\left(\bar{x}^{n}\right) \leftrightarrow \exists \bar{x}^{n} \psi_{n+1}\left(\bar{x}^{n+1}\right) 1 \leq n<\omega$.

Let us denote by what

$$
S_{k}\left(\bar{y}^{k}\right) \rightleftharpoons\left\{\begin{array}{l}
\psi_{n_{k}}\left(\bar{x}^{n_{k}}\right)\left(\begin{array}{c}
x_{i 1}, \ldots, x_{i k} \\
y_{1}, \ldots, y_{k}
\end{array}\right), \text { if } Z_{k}=\emptyset \\
\exists \ldots x_{S} \ldots \psi_{n_{k}}\left(\bar{x}^{n_{k}}\right)_{S \in Z_{k}}\left(\begin{array}{c}
x_{i 1}, \ldots, x_{i k} \\
y_{1}, \ldots, y_{k}
\end{array}\right), \text { if } Z_{k} \neq \emptyset
\end{array}\right.
$$

Then it is clear that:

a) $S_{k}\left(\bar{y}^{k}\right) \in \Sigma_{1} 1 \leq k<\omega$;

b) $S\left(\bar{y}^{k}\right)$ consistent with $T, 1 \leq k<\omega$;

c) $S\left(\bar{y}^{k}\right)$ generates $t_{\Sigma_{1}}^{\mathfrak{A}}\left(\bar{b}^{k}\right), 1 \leq k<\omega$;

d) $T \vdash S_{k}\left(\bar{y}^{k}\right) \leftrightarrow \exists y_{k+1} S_{k+1}\left(\bar{y}^{k+1}\right), 1 \leq k<\omega$.

Further such that $\mathfrak{B}$ is isomorphic embedding $\mathfrak{A}$, then $t_{\Sigma}^{\mathfrak{B}}\left(\bar{b}^{k}\right) \subseteq t_{\Sigma}^{\mathfrak{A}}\left(\bar{a}^{k}\right)$. Hence $S\left(\bar{y}^{k}\right)$ generates $t_{\Sigma}^{\mathfrak{B}}\left(\bar{b}^{k}\right)$ $1 \leq k<\omega$. Thus, since $\bar{b}^{\omega}$ is arbitrary, the model $\mathfrak{B}$ is fine almost-weakly $(\Sigma, \Sigma)$-cl atomic model $T$.

Corollary 10. Let $\mathfrak{A}=T, \bar{a}^{\omega}=A$. Then:

1) if $\bar{a}^{\omega}$ implements $\Sigma$ is principle type $\Sigma$ - $\omega$-type, then any infinite $a^{\omega}$ implements some $\Sigma$-principle type $\Sigma$ - $\omega$-type;

$2)$ if $\mathfrak{A}$ is the fine an almost-weekly $(\Sigma, \Sigma)$-cl atomic model $T$, then $\mathfrak{A}$ is almost-weakly $(\Sigma, \Sigma)$-cl atomic model $T$.

Proof. Follows from Lemma 9.

Lemma 11. Let $T$ has a fine almost-weakly $(\Sigma, \Sigma)$-cl atomic model, then each $(\Sigma, \Sigma)$-cl algebraically prime model of theory $T$ is a fine almost-weekly $(\Sigma, \Sigma)$-cl atomic model of the theory $T$.

Proof. Let $\mathfrak{B}$ be an arbitrary $(\Sigma, \Sigma)$-cl algebraically prime model of theory $T, \mathfrak{A}$ is fine an almost-weekly $(\Sigma, \Sigma)$-cl atomic model of the theory $T$, then there is an embedding $f: \mathfrak{A} \rightarrow \mathfrak{B}$. Let $\mathfrak{A}^{\prime}=f[\mathfrak{B}]$. Obviously $\mathfrak{A}^{\prime}$ embedded in $\mathfrak{A}$, and by Lemma $9 \mathfrak{A}^{\prime}$, therefore $\mathfrak{B}$ is also fine almost-weakly $(\Sigma, \Sigma)$-cl-atomic models of the theory $T$.

Lemma 12. Let $T$ perfect Jonsson theory complete for $\Pi_{1}$-sentences. Then every fine almost-weakly $(\Sigma, \Sigma)$ $c l$-atomic models of the theory $T$ is a $(\Sigma, \Sigma)$-cl algebraically prime model of $T$. 
Proof. Let $\bar{a}^{\omega}=<a_{1}, \ldots, a_{n}, \ldots>$ are elements from $A$. Since $\bar{a}^{\omega}$ implements $\Sigma_{1}$-principal $\Sigma_{1}-\omega$-type, there exists $\left\langle\psi_{n}\left(\bar{x}^{n}\right): 1 \leq n<\omega\right\rangle$ - is a sequence of $\Sigma_{1}$-formulas for which the condition of item 3 of Definition 7 is true. Such that $T$ is complete for $\Pi_{1}$-sentences, then $\mathfrak{B}=\exists \bar{x}^{n} \psi_{n}\left(\bar{x}^{n}\right), 1 \leq n<\omega$, where $\mathfrak{B} \models T$. Further, since $T \vdash \psi_{n}\left(\bar{x}^{n}\right) \leftrightarrow \exists \bar{x}^{n+1} \psi_{n+1}\left(\bar{x}^{n+1}\right)$ for each $1 \leq n<\omega$, then it is possible (step by step) to gradually find such $b_{1}, \ldots, b_{n}$ from $B$, such that $\mathfrak{B} \models \psi_{n}\left(\bar{x}^{n}\right), 1 \leq n<\omega$, where $\bar{b}^{n}=\left\langle b_{1}, \ldots, b_{n}\right\rangle$. But $\psi_{n}\left(\bar{x}^{n}\right)$ generates $t_{\Sigma_{1}}^{\mathfrak{A}}\left(\bar{a}^{n}\right)$, so $t_{\Sigma_{1}}^{\mathfrak{A}}\left(\bar{a}^{n}\right) \subseteq t_{\Sigma_{1}}^{\mathfrak{B}}\left(\bar{b}^{n}\right), 1 \leq n<\omega$.

Therefore, the mapping $f: \mathfrak{A} \rightarrow \mathfrak{B}$, where $f\left(a_{n}\right)=b_{n}, 1 \leq n<\omega$, is an isomorphic embedding.

Theorem 13. Let $T$ be the perfect Jonsson theory complete for $\Pi_{1}$-sentences and has fine almost-weakly $(\Sigma, \Sigma)-c l$ atomic model. Then the following conditions are equivalent:

1) $\mathfrak{A}$ is the $(\Sigma, \Sigma)$-cl algebraically prime model of theory $T$.

2) $\mathfrak{A}$ is the fine almost-weakly $(\Sigma, \Sigma)$-cl atomic model of the theory $T$.

Proof. 1) $\Rightarrow$ 2) follows from Lemma 11. 2) $\Rightarrow$ 1) from Lemma 12.

\section{Acknowledgments}

This work was supported by the Science Committee of the Ministry of Education and Science of the Republic of Kazakhstan (grant AP09260237).

\section{References}

1 Vaught R. Denumerable models of complete theories in Infinitistic Methode / R. Vaught // Pergamon, London. - 1961. - P. 303-321.

2 Baldwin J.T. Algebraically prime models / J.T. Baldwin, D.W. Kueker // Ann. Math. Logic. - 1981. 20. - P. 289-330.

3 Yeshkeyev A.R. $\nabla$-cl-atomic and prime sets / A.R. Yeshkeyev, A.K. Issayeva // Bulletin of the Karaganda University. Mathematics series. - 2019. - 93. - No. 1. - P. 88-94. DOI 10.31489/2019 M1/88-94

4 Yeshkeyev A.R. The atomic definable subsets of semantic model / A.R. Yeshkeyev, A.K. Issayeva, N.M. Mussina // Bulletin of the Karaganda University. Mathematics series. - 2019. - 94. - No. 2. - P. 84-91. DOI 10.31489/2019M2/84-91

5 Yeshkeyev A.R. Closure of special atomic subsets of semantic model / A.R. Yeshkeyev, A.K. Issayeva, N.V. Popova // Bulletin of the Karaganda University. Mathematics series. - 2020. - 97. - No. 1. P. 97-103. DOI 10.31489/2020M1/97-103

6 Yeshkeyev A.R. Core Jonsson theories / A.R. Yeshkeyev, A.K. Issayeva, N.V. Popova // Bulletin of the Karaganda University. Mathematics series. - 2020. - 97. - No. 1. - P. 104-110. DOI 10.31489/2020M1 $/ 104-110$

7 Ешкеев А.Р. $\alpha$-алгебраические простые модели и виды атомных моделей теории / А.Р. Ешкеев, Т.Г. Мустафин // Теория алгебраических структур: сб. науч. тр. - Караганда, 1985. - С. 30-39.

8 Yeshkeyev A.R. Companions of the fragments in the Jonsson enrichment / A.R. Yeshkeyev // Bulletin of the Karaganda University. Mathematics series. - 2017. - 85. - No. 1. - P. 41-45. DOI 10.31489 $/ 2017 \mathrm{M} 1 / 41-45$

9 Yeshkeyev A.R. The Properties of Similarity for Jonsson's Theories and Their Models / A.R. Yeshkeyev // Bulletin of the Karaganda University. Mathematics series. - 2015. - 80. - No. 4. - P. 52-59.

10 Yeshkeyev A.R. Properties of hybrids of Jonsson theories / A.R. Yeshkeyev, N.M. Mussina // Bulletin of the Karaganda University. Mathematics series. - 2018. - 92. - No. 4. - P. 99-104. DOI 10.31489 /2018M4/99-104

11 Yeshkeyev A.R. Model-theoretical questions of the Jonsson spectrum / A.R. Yeshkeyev // Bulletin of the Karaganda University. Mathematics series. - 2020. - 98. - No. 2. - P. 165-173. DOI 10.31489 /2020M2/165-173

12 Yeshkeyev A.R. Method of the rheostat for studying properties of fragments of theoretical sets / A.R. Yeshkeyev // Bulletin of the Karaganda University. Mathematics series. - 2020. - 100. - No. 4. P. $152-159$. DOI $10.31489 / 2020 \mathrm{M} 4 / 152-159$

13 Ешкеев A.R. $J S p$-косемантичность $R$-модулей / A.R. Ешкеев, О.И. Ульбрихт // Сиб. электрон. мат. изв. $-2019 .-16$. - Р. 1233-1244. DOI 10.33048/semi.2019.16.084 
14 Chang C.C. Omitting tupes of prenex formulas / C.C. Chang // J. Sumb. Logic. - 1967. - 32. - No. 1. - P. 61-77.

15 Keisler H.J. Forsing and omitting tupes theorem / H.J. Keisler // Moscow. A.A. Studies. - 1973. - 8. - P. 96-133.

А.Р. Ешкеев, А.Қ. Исаева, Н.Қ. Шаматаева

Академик Е.А.Бөкетов атындавы Қараганды университеті, Қараванды, Қазақстан

\title{
Анықталған жиынының тұйықтау операторы көмегімен алынған атомдық және алгебралық жай модельдер туралы
}

\begin{abstract}
Мақалада қандай да бір бекітілген йонсондық теорияның семантикалық моделінің анықталған ішкі жиынында берілген қандайда бір тұйықтау операторының көмегімен алынған атомдық және жай модельдердің қасиеттері қарастырылған. Негізгі нәтиже ретінде атомдық және жай модельдерде анықталған эквиваленттілікті табу болып табылады, яғни бұл сәйкестік жақсы қасиеттерімен берілген қандай да бір модель бар деген шығады.
\end{abstract}

Kiлm сөздер: йонсондық теориясы, семантикалық модель, жай модель, атомдық модель, алгебралық жай модель, предгеометрия, анықталған ішкі жиын.

\author{
А.P. Ешкеев, А.К. Исаева, Н.К. Шаматаева
}

Карагандинский университет имени академика Е.А.Букетова, Караганда, Казахстан

\section{Об атомных и алгебраически простых моделях, полученных замыканием определимых множеств}

\begin{abstract}
В статье рассмотрены свойства атомных и простых моделей, полученных с помощью некоторого оператора замыкания, заданного на определимых подмножествах семантической модели некоторой фиксированной йонсоновской теории. Основным результатом явилось получение эквивалентности определенными таким образом атомной и простой моделей, причем это совпадение следует при предположении, что существует некоторая модель с хорошо заданными свойствами.
\end{abstract}

Ключевые слова: йонсоновская теория, семантическая модель, простая модель, атомная модель, алгебраически простая модель, предгеометрия, определимое подмножество.

\section{References}

1 Vaught, R. (1961). Denumerable models of complete theories in Infinitistic Methode. Pergamon, London, 303-321.

2 Baldwin, J.T., \& Kueker, D.W. (1981). Algebraically prime models. Ann. Math. Logic., 20, $289-330$.

3 Yeshkeyev, A.R., \& Issayeva, A.K. (2019). $\nabla$-cl-atomic and prime sets. Bulletin of the Karaganda University. Mathematics series, 93(1), 88-94. DOI 10.31489/2019M1/88-94

4 Yeshkeyev, A.R., Issayeva, A.K., \& Mussina, N.M. (2019). The atomic definable subsets of semantic model. Bulletin of the Karaganda University. Mathematics series, 94(2), 84-91. DOI 10.31489/2019M2/84-91

5 Yeshkeyev, A.R., Issayeva, A.K., \& Popova, N.V. (2020). Closure of special atomic subsets of semantic model. Bulletin of the Karaganda University. Mathematics series, 97(1), 97-103. DOI 10.31489/2020M1 $/ 97-103$ 
6 Yeshkeyev, A.R., Issayeva, A.K., \& Popova, N.V. (2020). Core Jonsson theories. Bulletin of the Karaganda University. Mathematics series, 97(1), 104-110. DOI 10.31489/2020M1/104-110

7 Yeshkeyev, A.R., \& Mustafin, T.G. (1985). $\alpha$-algebraicheskie prostye modeli i vidy atomnykh modelei teorii [ $\alpha$-algebraically prime models and types of atomic theory models.] Teoriia algebraicheskikh struktur: sbornik nachnykh trudov, 30-39 [in Russian].

8 Yeshkeyev, A.R. (2017). Companions of the fragments in the Jonsson enrichment. Bulletin of the Karaganda University. Mathematics series, 85(1), 41-45. DOI 10.31489/2017M1/41-45

9 Yeshkeyev, A.R. (2015). The Properties of Similarity for Jonsson's Theories and Their Models. Bulletin of the Karaganda University. Mathematics series, 80(4), 52-59.

10 Yeshkeyev, A.R., \& Mussina, N.M (2018). Properties of hybrids of Jonsson theories. Bulletin of the Karaganda University. Mathematics series, 92(4), 99-104. DOI 10.31489/2018M4/99-104

11 Yeshkeyev, A.R. (2020). Model-theoretical questions of the Jonsson spectrum. Bulletin of the Karaganda University. Mathematics series, 98(2), 165-173. DOI 10.31489/2020M2/165-173

12 Yeshkeyev, A.R. (2020). Method of the rheostat for studying properties of fragments of theoretical sets. Bulletin of the Karaganda University. Mathematics series, $100(4), 152-159$. DOI 10.31489/2020M4/152159

13 Yeshkeyev, A.R., \& Ulbrikht, O.I. (2019). JSp-kosemantichnost $R$-modulei [JSp-cosemanticness of $R$-modules]. Sibirskie electronnye matematicheskie izvestia - Siberian electronic mathematical reports, 16 , 1233-1244. DOI 10.33048/ semi.2019.16.084 [in Russian]

14 Chang, C.C. (1967). Omitting tupes of prenex formulas. J. Sumb. Logic, 32(1), 61-77.

15 Keisler, H.J. (1973). Forsing and omitting tupes theorem. Moscow. A.A. Studies, 8, 96-133. 


\author{
G.A. Yessenbayeva ${ }^{1, *}$, G.A. Yessenbayeva ${ }^{2}$, A.T. Kasimov ${ }^{3}$, N.K. Syzdykova ${ }^{1}$ \\ ${ }^{1}$ Karagandy university of the name of academician E.A. Buketov, Karaganda, Kazakhstan; \\ ${ }^{2}$ Karaganda University of Kazpotrebsoyuz, Karaganda, Kazakhstan; \\ ${ }^{3}$ Karaganda Technical University, Karaganda, Kazakhstan \\ (E-mail: work.ksu21@mail.ru, esenbaeva_keu@mail.ru,kasimov5301@mail.ru,s_nazym_1807@mail.ru)
}

\title{
On the boundedness of the partial sums operator for the Fourier series in the function classes families associated with harmonic intervals
}

\begin{abstract}
The article is devoted to the study of some data from the theory of functions approximation by trigonometric polynomials with a spectrum from special sets called harmonic intervals. Due to the limited perception range of devices, the perception range of the senses of the person himself, when studying a mathematical model it is often enough to find an approximation of the object so that the error (noise, interference, distortion) is outside the interval of perception. Harmonic intervals model problems of this kind to some extent. In the article the main components of the approximation theory of functions by trigonometric polynomials with a spectrum from harmonic intervals are presented, the theorem on estimating the best approximation of a function by trigonometric polynomials through the best approximations of a function by trigonometric polynomials with a spectrum from harmonic intervals is proved. Theorems on the boundedness of the partial sums operator for the Fourier series in the function classes families associated with harmonic intervals are considered; such a theorem for the Lorentz space is generalized and proved. The article is mainly aimed at scientific researchers dealing with practical applications of the approximation theory of functions by trigonometric polynomials with a spectrum from special sets.
\end{abstract}

Keywords: harmonic interval, trigonometric polynomials with a spectrum from harmonic intervals, best approximation of a function by trigonometric polynomials, partial sums operator of the Fourier series for a given function, interpolation theorem.

\section{Introduction}

In approximation theory one of the most relevant problems is the approximation of periodic functions by polynomials with a spectrum from special families of sets. Here we note the works of K.I. Babenko, S.A. Telyakovsky, V.N. Temlyakov [1] and others in the case when the spectrum is a hyperbolic cross; the works of V.I. Yudin, M.I. Dyachenko [2] in the case when the spectrum is a ball, etc.

In the study of many applied problems the question of approximating the mathematical model of the object under study naturally arises. However, due to the limited range of perception («window of perception») of devices, the range of perception of the human senses, when studying a mathematical model it is often enough to find an approximation of the object so that the error (noise, interference, distortion) is outside the interval («window») of perception.

In this paper we consider approximations of functions by trigonometric polynomials with a spectrum from harmonic intervals, which to some extent model problems of this kind.

Note that harmonic intervals are some fractal self-similar sets, the concept of which was introduced by E.D. Nursultanov in [3-5] and, as it turned out, harmonic intervals have an important role in harmonic analysis. Thus, in the works of N.T. Tleukhanova, K.S. Saydakhmetov, D.S. Karimov, such objects as harmonic segments and harmonic intervals were essentially used.

In the studying the problem of the boundedness of the partial sums operator for the Fourier series in the function classes families associated with the best approximations over harmonic intervals the method of real interpolation is used. Among the works devoted to the properties of interpolation spaces, as well as to the methods of interpolation, one should note the works of Y. Berg and J. Lefstrom [6], S.G. Krein, Yu.I. Petunin, E.M. Semenov, Yu.A. Brudny [7], [8], H. Tribel [9], [10].

\footnotetext{
${ }^{*}$ Corresponding author.

E-mail: work.ksu21@mail.ru
} 


\section{Definitions and auxiliary results}

Let $k, \nu, N \in \mathbb{N}, k<N$. A set of the form

$$
I_{k}^{N}=\bigcup_{\nu=-\infty}^{\infty}([-k, k]+2 \nu N)=\bigcup_{\nu=-\infty}^{\infty}(m+2 \nu N: m \in[-k, k])
$$

is called a harmonic interval in $\mathbb{Z}$.

We denote by $T_{k}^{N}$ the set of trigonometric polynomials of the form

$$
T_{k}^{N}=\left\{\sum_{\nu=-s}^{s} a_{\nu} \cdot e^{i \nu x}: a_{\nu}=0 \text { if } \nu \notin I_{k}^{N}, s \in \mathbb{N}\right\}
$$

The value

$$
E_{k}^{N}(f)_{p}=\inf _{t \in T_{k}^{N}}\|f-t\|_{p}
$$

is called the best approximation over the harmonic interval $I_{k}^{N}$ of the function $f \in L_{p}[0,2 \pi), 1 \leq p \leq \infty$, by trigonometric polynomials from $T_{k}^{N}$ of order less than or equal to $k$.

Let $f \in L_{p}[0,2 \pi), 1 \leq p \leq \infty$. The partial sum of the Fourier series for the function $f$ over the harmonic interval $I_{k}^{N}$ is called the function

$$
S_{k}^{N}(f)=\sum_{\nu \in I_{k}^{N}} a_{\nu} \cdot e^{i \nu x} .
$$

Theorem 1. [11] Let $f \in L_{p}[0,2 \pi), 1<p<\infty, m \in \mathbb{N}$. $S_{m}^{N}(f)$ and $E_{m}^{N}(f)$ are the partial sum of the Fourier series and the best approximation of the function $f$ over the harmonic interval $I_{m}^{N}$ respectively, then we have the following relation

$$
E_{m}^{N}(f)_{p} \sim\left\|f-S_{m}^{N}(f)\right\|_{p} .
$$

Lemma 1. [11] Let $n \in \mathbb{N}, 1 \leq p<q \leq \infty, 1 \leq r \leq \infty$, then

$$
\left\|T_{n}\right\|_{L_{q, r}} \leq C n^{\frac{1}{p}-\frac{1}{q}}\left\|T_{n}\right\|_{L_{p}} .
$$

Let $1 \leq p, q \leq \infty, r>0, f \in L_{p}[0,2 \pi)$. The family of function classes $\left\{B_{p, q . N}^{r}\right\}_{N}$ is defined by the equality

$$
B_{p, q . N}^{r}=\left\{f:\|f\|_{B_{p, q . N}^{r}}<\infty\right\}, N \in \mathbb{N}
$$

where

$$
\|f\|_{B_{p, q . N}^{r}}=\left(\sum_{k=1}^{N} k^{r q-1}\left(E_{k-1}^{N}(f)_{p}\right)^{q}\right)^{\frac{1}{q}} .
$$

Let two families of function classes $\left\{A^{N}\right\}_{N}$ and $\left\{B^{N}\right\}_{N}, N \in \mathbb{N}$, be given. We assume that the ratio

$$
\|f\|_{A^{N}} \sim\|f\|_{B^{N}}
$$

holds if there are parameters $C_{1}, C_{2}$ such that for any $f \in A^{N}$ the following inequality

$$
C_{1}\|f\|_{B^{N}} \leq\|f\|_{A^{N}} \leq C_{2}\|f\|_{B^{N}}
$$

is valid, moreover, the parameters $C_{1}, C_{2}$ do not depend on $f$ and $N$.

Theorem 2. [12] Let $f \in B_{p, q .2^{m}}^{r}, m \in \mathbb{N}$. Then for $1 \leq p, q \leq \infty, r>0$ we have

$$
\|f\|_{B_{p, q \cdot 2^{m}}^{r}} \sim\left(\sum_{k=1}^{m} 2^{r q k}\left(E_{2^{k}-1}^{2^{m}}(f)_{p}\right)^{q}\right)^{\frac{1}{q}} .
$$

Theorem 3. [12] Let $m \in \mathbb{N}, 1 \leq p, p_{0}, p_{1} \leq \infty, 0<\theta<1, r_{0}>0, r_{1}>0, r_{0} \neq r_{1}, \frac{1}{p}=\frac{1-\theta}{p_{0}}+\frac{\theta}{p_{1}}$, $r=(1-\theta) \cdot r_{0}+\theta \cdot r_{1}$, then

$$
\left(B_{p_{0}, p_{0}, 2^{m}}^{r_{0}} ; B_{p_{1}, p_{1}, 2^{m}}^{r_{1}}\right)_{\theta, p}=B_{p, p, 2^{m}}^{r} .
$$


Estimation by the best approximations over harmonic intervals

Theorem 4. Let $f \in L_{p}[0,2 \pi), 1<p<\infty, n \in \mathbb{N}$. $\sum_{\nu \in \mathbb{Z}} a_{\nu} \cdot e^{i \nu x}$ is the trigonometric Fourier series of the function $f$, then the following inequality holds

$$
E_{n}(f)_{p} \leq \sum_{j=1}^{\infty} E_{\left(2^{j}-1\right) \cdot n}^{2^{j} \cdot n}(f)_{p}
$$

Proof. By Lemma 9.3 [13] we have

$$
E_{n}(f)_{p} \sim\left\|f-S_{n}(f)\right\|_{p},
$$

when $1<p<\infty$ or

$$
E_{n}(f)_{p} \sim\left\|\sum_{\nu \in Z \backslash[-n, n]} a_{\nu} \cdot e^{i \nu x}\right\| .
$$

By entering the notation of harmonic intervals in $\mathbb{Z}$

$$
\begin{gathered}
V_{j}=\bigcup_{m=-\infty}^{\infty}\left\{\left[\left(2^{j}-1\right) n ;\left(2^{j}+1\right) n\right]+2^{j+1} m n\right\}= \\
=\bigcup_{m=-\infty}^{\infty}\left\{[-n ; n]+2^{j} n(2 m+1)\right\}, \quad j=1,2, \ldots,
\end{gathered}
$$

we obtain

$$
\mathbb{Z} \backslash[-n ; n]=\bigcup_{j=1}^{\infty} V_{j} .
$$

Then from (2) we get the relation in this form

$$
E_{n}(f)_{p} \sim\left\|\sum_{j=1}^{\infty} \sum_{\nu \in V_{j}} a_{\nu} \cdot e^{i \nu x}\right\|_{p}=\left\|\sum_{j=1}^{\infty} \sum_{m=-\infty}^{\infty} \sum_{s=n\left[2^{j}(2 m+1)-1\right]}^{n\left[2^{j}(2 m+1)+1\right]} a_{s} \cdot e^{i s x}\right\|_{p} .
$$

We denote by $W_{j}, j=1,2, \ldots$, the following sets

$$
W_{j}=\mathbb{Z} \backslash V_{j},
$$

where

$$
W_{j}=\bigcup_{m=-\infty}^{\infty}\left\{\left[-\left(2^{j}-1\right) n ;\left(2^{j}-1\right) n\right]+2^{j+1} m n\right\}
$$

or

$$
W_{j}=I_{\left(2^{j}-1\right) n}^{2^{j} n} .
$$

We note that the sets $W_{j}, j=1,2, \ldots$ are also harmonic intervals in $\mathbb{Z}$ as complements of the harmonic intervals $V_{j}, j=1,2, \ldots$ in $\mathbb{Z}$. Then, according to Theorem 1 , using (4), from (3) we obtain the required inequality

$$
\begin{gathered}
E_{n}(f)_{p} \sim\left\|\sum_{j=1}^{\infty} \sum_{\nu \in \mathbb{Z} \backslash W_{j}} a_{\nu} \cdot e^{i \nu x}\right\|_{p}=\left\|\sum_{j=1}^{\infty}\left(f-S_{W_{j}}(f)\right)\right\|_{p} \leq \\
\leq \sum_{j=1}^{\infty}\left\|\left(f-S_{W_{j}}(f)\right)\right\|_{p} \sim \sum_{j=1}^{\infty} E_{W_{j}}(f)_{p}, \\
E_{n}(f)_{p} \leq \sum_{j=1}^{\infty} E_{\left(2^{j}-1\right) \cdot n}^{2^{j} \cdot n}(f)_{p} .
\end{gathered}
$$

The theorem is proved. 
Theorems on the boundedness of the partial sums operator for the Fourier series of a function $f$ in the function classes families $\left\{B_{p, q . N}^{r}\right\}_{N}$

Theorem 5. [11] Let $N \in \mathbb{N}, 1 \leq p<q \leq \infty, 1 \leq r \leq \infty, \beta>0, \alpha-\beta=\frac{1}{p}-\frac{1}{q}$. $B_{q, r}^{\beta}$ is the Besov space [14], then the partial sums operator for the trigonometric Fourier series of the function $f$

$$
S_{N}(f(x))=\sum_{k=-N}^{N} \widehat{f}(k) e^{i k x}
$$

such that

$$
S_{N}: B_{p, r, N}^{\alpha} \rightarrow B_{q, r}^{\beta}
$$

is bounded, that is, there is the inequality

$$
\left\|S_{N}(f)\right\|_{B_{q, r}^{\beta}} \leq C\|f\|_{B_{p, r, N}^{\alpha}},
$$

where the parameter $C$ do not depend on $f$ and $N$.

Corollary 1. [11] Let $N \in \mathbb{N}, 1 \leq p<q \leq \infty, 1 \leq r \leq \infty, \beta>0, \alpha-\beta=\frac{1}{p}-\frac{1}{q}$, then the partial sums operator for the trigonometric Fourier series of the function $f$

$$
S_{N}: B_{p, r, N}^{\alpha} \rightarrow B_{q, r, N}^{\beta}
$$

is bounded, that is, the following inequality

$$
\left\|S_{N}(f)\right\|_{B_{q, r, N}^{\beta}} \leq C\|f\|_{B_{p, r, N}^{\alpha}}
$$

where the parameter $C$ do not depend on $f$ and $N$.

Theorem 6. [11] Let $m \in \mathbb{N}, 1 \leq p<q \leq \infty, \alpha=\frac{1}{p}-\frac{1}{q}$, then the partial sums operator for the trigonometric Fourier series of the function $f$

$$
S_{2^{m}}: B_{p, q, 2^{m}}^{\alpha} \rightarrow L_{q}
$$

is bounded, that is, we have the following inequality

$$
\left\|S_{2^{m}}(f)\right\|_{L_{q}} \leq C\|f\|_{B_{p, q, 2^{m}}^{\alpha}},
$$

where the parameter $C$ do not depend on $f$ and $m$.

Remark 1. Theorem 6 can be formulated in a more general form.

Let $N \in \mathbb{N}, 1 \leq p<q \leq \infty, \alpha=\frac{1}{p}-\frac{1}{q}$, then the partial sums operator for the trigonometric Fourier series of the function $\mathrm{f}$

$$
S_{N}: B_{p, q, N}^{\alpha} \rightarrow L_{q}
$$

is bounded, that is, there is the inequality of the form

$$
\left\|S_{N}(f)\right\|_{L_{q}} \leq C\|f\|_{B_{p, q, N}^{\alpha}},
$$

where the parameter $C$ do not depend on $f$ and $N$.

We generalize Theorem 6 to Lorentz spaces.

Theorem 7. Let $N \in \mathbb{N}, 1 \leq p<q \leq \infty, 1 \leq r \leq \infty, \alpha=\frac{1}{p}-\frac{1}{q}$, then the partial sums operator for the trigonometric Fourier series of the function $f$

$$
S_{N}: B_{p, r, N}^{\alpha} \rightarrow L_{q, r}
$$

is bounded, that is, this inequality holds

$$
\left\|S_{N}(f)\right\|_{L_{q, r}} \leq C\|f\|_{B_{p, r, N}^{\alpha}},
$$

where the parameter $C$ do not depend on $f$ and $N$. 
Proof. We estimate the norm of the partial sum operator in the Lorentz space

$$
\left\|S_{N}(f)\right\|_{L_{q, r}} \leq \sum_{k=1}^{\left[\log _{2} N\right]}\left\|\sum_{n=-2^{k-1}}^{2^{k}-1} a_{n} e^{i n x}\right\|_{L_{q, r}}=\sum_{k=1}^{\left[\log _{2} N\right]}\left\|\Delta_{k}\left(S_{N}(f)\right)\right\|_{L_{q, r}} .
$$

Applying the inequality of different metrics (1), we transform the relation (5) as follows

$$
\left\|S_{N}(f)\right\|_{L_{q, r}} \leq C \sum_{k=1}^{\left[\log _{2} N\right]} 2^{k\left(\frac{1}{p}-\frac{1}{q}\right)}\left\|\Delta_{k}\left(S_{N}(f)\right)\right\|_{L_{p}}=C \sum_{k=1}^{\left[\log _{2} N\right]} 2^{\alpha k}\left\|\Delta_{k}\left(S_{N}(f)\right)\right\|_{L_{p}} .
$$

Taking into account that $\triangle_{k}\left(S_{N}(f)\right)$ is a partial sum of the function $\sum_{n \in \mathbb{Z} \backslash I_{2^{k-1}-1}^{N}} a_{n} e^{i n x}$ and using the M. Riesz theorem [15], Theorem 1 and Theorem 2, we reduce relation (6) to the form

$$
\begin{gathered}
\left\|S_{N}(f)\right\|_{L_{q, r}} \leq C \sum_{k=1}^{\left[\log _{2} N\right]} 2^{\alpha k}\left\|\Delta_{k}\left(S_{N}(f)\right)\right\|_{L_{p}} \leq \\
\leq C \sum_{k=1}^{\left[\log _{2} N\right]} 2^{\alpha k}\left\|_{n \in \mathbb{Z} \backslash I_{2^{k-1}-1}^{N}} a_{n} e^{i n x}\right\|_{L_{p}}=C \sum_{k=1}^{\left[\log _{2} N\right]} 2^{\alpha k}\left\|f-S_{2^{k-1}-1}^{N}(f)\right\|_{L_{p}} \leq \\
\leq C \sum_{k=1}^{\left[\log _{2} N\right]} 2^{\alpha k} E_{2^{k-1}-1}^{N}(f)_{p}=C \cdot 2^{\alpha} \sum_{k=1}^{\left[\log _{2} N\right]} 2^{\alpha(k-1)} E_{2^{k-1}-1}^{N}(f)_{p} \leq \\
\leq C \sum_{k=1}^{\left[\log _{2} N\right]} 2^{\alpha k} E_{2^{k}-1}^{N}(f)_{p} \sim C\|f\|_{B_{p, 1, N}^{\alpha}} . \\
\Rightarrow\left\|S_{N}(f)\right\|_{L_{q, r}} \leq C\|f\|_{B_{p, 1, N}^{\alpha}} .
\end{gathered}
$$

We take pairs $\left(\alpha_{0}, \alpha_{1}\right),\left(q_{0}, q_{1}\right),\left(r_{0}, r_{1}\right)$ that satisfy the following conditions

$$
\begin{gathered}
\alpha_{0}<\alpha<\alpha_{1}, \quad q_{0}<q<q_{1}, \quad r_{0}<r<r_{1}, \\
\alpha_{0}=\frac{1}{p}-\frac{1}{q_{0}}, \quad \alpha_{1}=\frac{1}{p}-\frac{1}{q_{1}} .
\end{gathered}
$$

Taking into account the relation (7), we obtain the following

$$
\begin{gathered}
S_{N}: B_{p, 1, N}^{\alpha_{0}} \rightarrow L_{q_{0}, r_{0}}, \\
S_{N}: B_{p, 1, N}^{\alpha_{1}} \rightarrow L_{q_{1}, r_{1}}
\end{gathered}
$$

then, by the interpolation theorem [6], we have

$$
S_{N}:\left(B_{p, 1, N}^{\alpha_{0}} ; B_{p, 1, N}^{\alpha_{1}}\right)_{\theta, r} \rightarrow\left(L_{q_{0}, r_{0}} ; L_{q_{1}, r_{1}}\right)_{\theta, r} .
$$

Using Theorem 3, we receive that this relation holds

$$
\left(B_{p, 1, N}^{\alpha_{0}} ; B_{p, 1, N}^{\alpha_{1}}\right)_{\theta, r}=B_{p, r, N}^{\alpha_{\theta}}
$$

where

$$
\alpha_{\theta}=(1-\theta) \cdot \alpha_{0}+\theta \cdot \alpha_{1}, \frac{1}{r}=\frac{1-\theta}{r_{0}}+\frac{\theta}{r_{1}}, 0<\theta<1 .
$$

It follows from the theorem on the interpolation of Lorentz spaces [6] that

$$
\left(L_{q_{0}, r_{0}} ; L_{q_{1}, r_{1}}\right)_{\theta, r}=L_{q_{\theta}, r},
$$


where

$$
\frac{1}{q_{\theta}}=\frac{1-\theta}{q_{0}}+\frac{\theta}{q_{1}}, \frac{1}{r}=\frac{1-\theta}{r_{0}}+\frac{\theta}{r_{1}}
$$

Since there is a dependency

$$
\alpha_{\theta}=(1-\theta) \cdot \alpha_{0}+\theta \cdot \alpha_{1}=(1-\theta)\left(\frac{1}{p}-\frac{1}{q_{0}}\right)+\theta\left(\frac{1}{p}-\frac{1}{q_{1}}\right)=\frac{1}{p}-\frac{1}{q_{\theta}},
$$

then there is $\theta \in(0 ; 1)$ such that

$$
\alpha_{\theta}=\alpha, q_{\theta}=q
$$

As a result, from (8) we obtain the required relation

$$
S_{N}: B_{p, r, N}^{\alpha} \rightarrow L_{q, r},
$$

and

$$
\left\|S_{N}(f)\right\|_{L_{q, r}} \leq C\|f\|_{B_{p, r, N}^{\alpha}} .
$$

where the parameter $C$ do not depend on $f$ and $N$.

The theorem is proved.

Remark 2. In Theorems 5, 7 and Remark 1, the operator $S_{N}(f)$ can be replaced by the operator $S_{n}(f)$, where $0 \leq n \leq N$. Indeed, from M. Riesz's theorem we have

$$
\left\|S_{n}(f)\right\|_{L_{p}} \leq C\left\|S_{N}(f)\right\|_{L_{p}},
$$

where the parameter $C$ do not depend on $f$ and $N$.

\section{References}

1 Темляков В.Н. Дискретизация интегральных норм полиномов с гармониками из гиперболического креста по значениям в точках / В.Н. Темляков // Функциональные пространства, теория приближений и смежные вопросы анализа: сб. ст. к 115-летию со дня рожд. акад. Сергея Михайловича Никольского // Тр. МИАН. - 2021. - 312. - С. 282-293.

2 Теляковский С.А. Очерки развития математики в СССР / С.А. Теляковский. - Киев: Наук. думка, 1983. - C. 237-251.

3 Нурсултанов Е.Д. Сетевые пространства и их приложения к задачам гармонического анализа: дис. ... д-ра ф.-м. наук: 01.01.01 - Вещественный, комплексный и функциональный анализ / Ерлан Даутбекович Нурсултанов. - М., 1999. - С. 171-179.

4 Нурсултанов Е.Д. Сетевые пространства и неравенства Харди-Литтлвуда / Е.Д. Нурсултанов // Мат. сб. - 1998. - Т. 189. - № 3. - С. 83-102.

5 Нурсултанов Е.Д. Сетевые пространства и преобразование Фурье / Е.Д. Нурсултанов // Док. РАН (361). - 1998. - № 5. - С. 597-599.

6 Берг Й. Интерполяционные пространства. Введение / Й. Берг, Й. Лефстрем. - М.: Мир, 1980. $264 \mathrm{c.}$

7 Крейн С.Г. Интерполяция линейных операторов / С.Г. Крейн, Ю.И. Петунин, Е.М. Семенов. - М.: Наука, 1978. - 400 с.

8 Брудный Ю.А. Интерполяция линейных операторов / Ю.А. Брудный, С.Г. Крейн, Е.М. Семенов // Итоги науки и техн. Сер. Мат. анал. - 1986. - Т. 24. - С. 3-163.

9 Трибель Х. Теория интерполяции, функциональные пространства, дифференциальные операторы / Х. Трибель. - М.: Мир, 1980. - 664 с.

10 Трибель Х. Теория функциональных пространств / Х. Трибель. - М.: Мир, 1986. - 448 с.

11 Есенбаева Г.А. О свойствах частичных сумм по гармоническим интервалам и классах функций, связанных с наилучшими приближениями по гармоническим интервалам / Г.А. Есенбаева // Вестн. Караганд. ун-та. Сер. Математика. - 2008. - № 1(49). - С. 29-36. 
12 Есенбаева Г.А. Интерполяция некоторых неравенств и аппроксимация функций тригонометрическими полиномами со спектром из гармонических интервалов / Г.А. Есенбаева, Е.Д. Нурсултанов // Евраз. мат. журн. - 2004. - № 1. - С. 3-20.

13 Смаилов Е.С. Теория приближения и вложения классов функций многих переменных / Е.С. Смаилов, Г.А. Акишев, М.Г. Есмаганбетов. - Караганда: Изд-во КарГУ, 1986. - 87 с.

14 Никольский С.М. Приближение функций многих переменных и теоремы вложения / С.М. Никольский. - М.: Наука, 1977. - 456 с.

15 Бари Н.К. Тригонометрические ряды / Н.К. Бари. - М.: Физматлит, 1961. - 936 с.

\author{
Г.А. Есенбаева ${ }^{1}$, Г.А. Есенбаева ${ }^{2}$, А.Т. Касимов ${ }^{3}$, Н.К. Сыздыкова ${ }^{1}$ \\ ${ }^{1}$ Академик Е.А.Бөкетов атындавы Қараганды университеті, Қараванды, Қазақстан; \\ ${ }^{2}$ Қазтұтынуодавы Қараванды университеті, Қараванды, Қазақстан; \\ ${ }^{3}$ Қараванды техникалық, университеті, Қараганды, Қазақстан
}

\title{
Гармоникалық интервалдармен байланысты функциялар кластары үйіріндегі Фурье қатарының дербес қосындылары операторының шенелгендігі туралы
}

\begin{abstract}
Мақала гармоникалық интервалдар деп аталатын арнайы жиынтықтар спектрі бар тригонометрикалық полиномдар функцияларын жуықтау теориясының кейбір деректерін зерттеуге арналған. Математикалық модельді зерттеу кезінде құрылғылардың қабылдау ауқымы, адамның сезім мүшелерінің қабылдау ауқымы шектеулі болғандықтан қателік (шу, кедергі, бұрмалау) қабылдау интервалынан тыс болатындай етіп қажетті объектінің жуықтамасын табу көбінесе жеткілікті болады. Гармоникалық интервалдар осындай типтегі мәселелерді белгілі бір деңгейде модельдейді. Мақалада гармоникалық интервалдар деп аталатын арнайы жиынтықтар спектрі бар тригонометрикалық полиномдар функцияларын жуықтау теориясының негізгі компоненттері келтірілген, гармоникалық интервалдар деп аталатын арнайы жиынтықтар спектрі бар тригонометрикалық полиномдар функциясын ең жақсы жуықтау арқылы тригонометрикалық полиномдар функциясын ең жақсы жуықтауды бағалау туралы теоремасы дәлелденді. Гармоникалық интервалдармен байланысты функциялар кластары үйіріндегі Фурье қатарының дербес қосындылары операторының шенелгендігі туралы теоремалар келтірілген, мұндай теорема Лоренц кеңістігі үшін жалпыландырылған және дәлелденген. Негізінен мақала арнайы жиынтықтар спектрі бар тригонометрикалық полиномдар функцияларын жуықтау теориясының практикалық қолдануымен айналысатын ғылыми зерттеушілерге арналған.
\end{abstract}

Kiлm сөздер: гармоникалық интервал, гармоникалық интервалдар спектрі бар тригонометрикалық полиномдар, тригонометрикалық полиномдар функциясын ең жақсы жуықтау, белгіленген функция үшін Фурье қатарының дербес қосындылары операторы, интерполяциялық теорема. 


\author{
Г.А. Есенбаева ${ }^{1}$, Г.А. Есенбаева ${ }^{2}$, А.Т. Касимов ${ }^{3}$, Н.К. Сыздыкова ${ }^{1}$ \\ ${ }^{1}$ Карагандинский университет имени академика Е.А. Букетова, Караганда, Казахстан; \\ ${ }^{2}$ Карагандинский университет Казпотребсоюза, Караганда, Казахстан; \\ ${ }^{3}$ Карагандинский технический университет, Караганда, Казахстан
}

\title{
Об ограниченности оператора частичных сумм ряда Фурье в семействах классов функций, связанных с гармоническими интервалами
}

\begin{abstract}
Статья посвящена исследованию некоторых данных теории приближения функций тригонометрическими полиномами со спектром из специальных множеств, называемых гармоническими интервалами. В силу ограниченности диапазона восприятия приборов, диапазона восприятия органов чувств самого человека при исследовании математической модели часто достаточно найти приближение искомого объекта так, чтобы погрешность (шумы, помехи, искажения) оказалась вне интервала восприятия. Гармонические интервалы в некоторой степени моделируют задачи такого рода. В статье представлены основные компоненты теории приближения функций тригонометрическими полиномами со спектром из гармонических интервалов, доказана теорема об оценке наилучшего приближения функции тригонометрическими полиномами через наилучшие приближения функции тригонометрическими полиномами со спектром из гармонических интервалов. Приведены теоремы об ограниченности оператора частичных сумм ряда Фурье в семействах классов функций, связанных с гармоническими интервалами, обобщена и доказана такая теорема для пространства Лоренца. Статья ориентирована, в основном, на научных исследователей, занимающихся практическими приложениями теории приближений функций тригонометрическими полиномами со спектром из специальных множеств.
\end{abstract}

Ключевые слова: гармонический интервал, тригонометрические полиномы со спектром из гармонических интервалов, наилучшее приближение функции тригонометрическими полиномами, оператор частичных сумм ряда Фурье для заданной функции, интерполяционная теорема.

\section{References}

1 Temlyakov, V.N. (2021). Diskretizatsiia integralnykh norm polinomov s garmonikami iz giperbolicheskogo kresta po znacheniiam v tochkakh [Discretization of integral norms for polynomials with harmonics from a hyperbolic cross by values at points]. Funktsionalnye prostranstva, teoriia priblizhenii $i$ smezhnye voprosy analiza: sbornik statei $k$ 115-letiiu so dnia rozhdeniia akademika Sergeia Mikhailovicha Nikolskogo. Trudy MIAN - Functional spaces, approximation theory, and related issues of analysis. Collection of articles dedicated to the 115th anniversary of the birth of academician Sergei Mikhailovich Nikolsky. Works of MIAS, 312, 282-293 [in Russian].

2 Telyakovsky, S.A. (1983). Ocherki razvitiia matematiki v SSSR [Essays on the development of mathematics in the USSR]. Kiev: Naukova dumka [in Russian].

3 Nursultanov, E.D. (1999). Setevye prostranstva i ikh prilozheniia k zadacham garmonicheskogo analiza [Network spaces and their applications to problems of harmonic analysis]. Doctor's thesis. Moscow [in Russian].

4 Nursultanov, E.D. (1998). Setevye prostranstva i neravenstva Hardi-Littlvuda [Network spaces and HardyLittlewood inequalities]. Matematicheskii sbornik - Mathematical collection, 189, 3, 83-102 [in Russian].

5 Nursultanov, E.D. (1998). Setevye prostranstva i preobrazovanie Fure [Network spaces and the Fourier transform]. Doklad RAN (361) - RAS report (361), 5, 597-599 [in Russian].

6 Berg, J., \& Lefstrom, J. (1980). Interpoliatsionnye prostranstva. Vvedenie [Interpolation spaces. Introduction]. Moscow: Mir [in Russian].

7 Krein, S.G., Petunin, Yu I., \& Semenov, E.M. (1978). Interpoliatsiia lineinykh operatorov [Interpolation of linear operators]. Moscow: Nauka [in Russian].

8 Brudny, Yu.A., Krein, S.G., \& Semenov, E.M. (1986). Interpoliatsiia lineinykh operatorov [Interpolation of linear operators]. Itogi nauki i tekhniki. Seriia Matematicheskii analiz - Results of Science and Technology. Ser. Math. anal., 24, 3-163 [in Russian]. 
9 Tribel, Kh. (1980). Teoriia interpoliatsii, funktsionalnye prostranstva, differensialnye operatory [Interpolation theory, function spaces, differential operators]. Moscow: Mir [in Russian].

10 Tribel, Kh. (1986). Teoriia funktsionalnykh prostranstv [Theory of functional spaces]. Moscow: Mir [in Russian].

11 Yessenbayeva, G.A. (2008). O svoistvakh chastichnykh summ po garmonicheskim intervalam i klassakh funktsii, sviazannykh s nailuchshimi priblizheniiami po garmonicheskim intervalam [On the properties of partial sums over harmonic intervals and classes of functions associated with the best approximations over harmonic intervals]. Vestnik Karagandinskogo universiteta. Seriia Matematika - Bulletin of the Karaganda University. Mathematics Series, 1(49), 29-36 [in Russian].

12 Yessenbayeva, G.A., \& Nursultanov, E.D. (2004). Interpoliatsiia nekotorykh neravenstv i approksimatsiia funktsii trigonometricheskimi polinomami so spektrom iz garmonicheskikh intervalov [Interpolation of some inequalities and approximation of functions by trigonometric polynomials with spectrum from harmonic intervals]. Evraziiskii matematicheskii zhurnal - Eurasian mathematical journal, 1, 3-20 [in Russian].

13 Smailov, E.S., Akishev, G.A., \& Esmaganbetov, M.G. (1986). Teoriia priblizheniia i vlozheniia klassov funktsii mnogikh peremennykh /Approximation theory and embeddings of classes of functions of many variables]. Karaganda: Izdatelstvo Karagandinskogo universiteta [in Russian].

14 Nikolsky, S.M. (1977). Priblizhenie funktsii mnogikh peremennykh i teoremy vlozheniia /Approximation of functions of many variables and embedding theorems]. Moscow: Nauka [in Russian].

15 Bari, N.K. (1961). Trigonometricheskie riady [Trigonometric series]. Moscow: Fizmatlit [in Russian]. 
DOI $10.31489 / 2021 \mathrm{M} 3 / 140-155$

UDC 517.911

\author{
T. K. Yuldashev ${ }^{1, *}$, B. J. Kadirkulov ${ }^{2}$, A. R. Marakhimov ${ }^{3}$ \\ ${ }^{1}$ National University of Uzbekistan, Tashkent, Uzbekistan; \\ ${ }^{2}$ Tashkent State University of Oriental Studies, Tashkent, Uzbekistan; \\ ${ }^{3}$ Termez State University, Termez, Uzbekistan \\ (E-mail: tursun.k.yuldashev@gmail.com,kadirkulovbj@gmail.com, rector@terdu.uz)
}

\title{
On a Hilfer Type Fractional Differential Equation with Nonlinear Right-Hand Side
}

\begin{abstract}
In this article we consider the questions of one-valued solvability and numerical realization of initial value problem for a nonlinear Hilfer type fractional differential equation with maxima. By the aid of uncomplicated integral transformation based on Dirichlet formula, this initial value problem is reduced to the nonlinear Volterra type fractional integral equation. The theorem of existence and uniqueness of the solution of given initial value problem in the segment under consideration is proved. For numerical realization of solution the generalized Jacobi-Galerkin method is applied. Illustrative examples are provided.
\end{abstract}

Keywords: Ordinary differential equation, equation with maxima, Hilfer operator, one-valued solvability, generalized Jacobi-Galerkin method.

\section{Introduction}

Let $\left(t_{0} ; b\right) \subset \mathbb{R}^{+} \equiv[0 ; \infty)$ be a finite interval on the set of positive real numbers, and let $\alpha>0$. The Riemann-Liouville $\alpha$-order fractional integral of a function $\eta(t)$ is defined as follows:

$$
I_{t_{0}+}^{\alpha} \eta(t)=\frac{1}{\Gamma(\alpha)} \int_{t_{0}}^{t}(t-s)^{\alpha-1} \eta(s) d s, \quad \alpha>0, \quad t \in\left(t_{0} ; b\right),
$$

where $\Gamma(\alpha)$ is the Gamma function $[1 ; 112]$.

Let $n-1<\alpha \leq n, n \in \mathbb{N}$. The Riemann-Liouville $\alpha$-order fractional derivative of a function $\eta(t)$ is defined as follows [2, Vol. 1, p. 27]:

$$
D_{t_{0}+}^{\alpha} \eta(t)=\frac{d^{n}}{d t^{n}} I_{t_{0}+}^{n-\alpha} \eta(t), \quad t \in\left(t_{0} ; b\right)
$$

The Caputo $\alpha$-order fractional derivative of a function $\eta(t)$ is defined [2, Vol. $1 ; 34]$ by

$$
{ }_{*} D_{t_{0}+}^{\alpha} \eta(t)=I_{t_{0}+}^{n-\alpha} \eta^{(n)}(t)=\frac{1}{\Gamma(n-\alpha)} \int_{t_{0}}^{t} \frac{\eta^{(n)}(s) d s}{(t-s)^{\alpha-n+1}}, \quad t \in\left(t_{0} ; b\right) .
$$

Both the derivatives are reduced to the $n$-th order derivatives for $\alpha=n \in \mathbb{N}[2$, Vol. $1 ; 27-34]$ :

$$
D_{t_{0}+}^{n} \eta(t)={ }_{*} D_{t_{0}+}^{n} \eta(t)=\frac{d^{n}}{d t^{n}} \eta(t), \quad t \in\left(t_{0} ; b\right) .
$$

The so-called generalized Riemann-Liouville fractional derivative (referred to as the Hilfer fractional derivative) of order $\alpha, n-1<\alpha \leq n, n \in \mathbb{N}$ and type $\beta, 0 \leq \beta \leq 1$ is defined by the following composition of three operators: [1; 113]:

$$
D_{t_{0}+}^{\alpha, \beta} \eta(t)=I_{t_{0}+}^{\beta(n-\alpha)} \frac{d^{n}}{d t^{n}} I_{t_{0}+}^{(1-\beta)(n-\alpha)} \eta(t), \quad t \in\left(t_{0} ; b\right) .
$$

${ }^{*}$ Corresponding author.

E-mail: tursun.k.yuldashev@gmail.com 
For $\beta=0$ this operator is reduced to the Riemann-Liouville fractional derivative $D_{t_{0}+}^{\alpha, 0}=D_{t_{0}+}^{\alpha}$ and the case $\beta=1$ corresponds to the Caputo fractional derivative $D_{t_{0}+}^{\alpha, 1}={ }_{*} D_{t_{0}+}^{\alpha}$.

Let $\gamma=\alpha+\beta n-\alpha \beta$. It is easy to see that $\alpha \leq \gamma \leq n$. Then it is convenient to use another designation for the operator $D_{t_{0}+}^{\alpha, \beta} \eta(t)$ :

$$
D^{\alpha, \gamma} \eta(t)=D_{t_{0}+}^{\alpha, \beta} \eta(t)
$$

The generalized Riemann-Liouville operator was introduced in [1] by R. Hilfer on the basis of fractional time evolutions that arise during the transition from the microscopic scale to the macroscopic time scale. Using the integral transforms, he investigated the Cauchy problem for the generalized diffusion equation, the solution of which is presented in the form of the Fox $H$-function. Note [3, 4], the generalized Riemann-Liouville operator was used in studying dielectric relaxation in glass-forming liquids with different chemical compositions. In [5] the properties of the generalized Riemann-Liouville operator were investigated in a special functional space, and an operational method was developed for solving fractional differential equations with this operator. Based on the results of the work [5], the authors of [6] have developed an operational method for solving fractional differential equations containing a finite linear combination of the generalized Riemann-Liouville operators with various parameters.

Fractional calculus plays an important role in the mathematical modelling of many scientific and engineering disciplines (see more detailed information in [7]). In [8] problems of continuum and statistical mechanics are considered. In [9] the mathematical problems of Ebola epidemic model are studied. In [10] and [11] the fractional model for the dynamics of tuberculosis infection and novel coronavirus (COViD-2019), respectively are studied. The construction of various models of theoretical physics by the aid of fractional calculus is described in [2, Vol. 4, 5], [12, 13]. A specific interpretation of the Hilfer fractional derivative, describing the random motion of a particle moving on the real line at Poisson paced times with finite velocity is given in [14]. A detailed review of the application of fractional calculus in solving problems of applied sciences is given in [2, Vol. 6-8], [15]. More detailed information related to the theory of fractional integro-differentiation, including the Hilfer fractional derivative one can find in the monograph [16]. In [17] the unique solvability of boundary value problem for weak nonlinear partial differential equations of mixed type with fractional Hilfer operator is studied by analytical method. In [18] the solvability of nonlocal problem for a mixed type fourth-order differential equation with Hilfer fractional operator is studied. In [19] it is considered an inverse problem for a mixed type integro-differential equation with fractional order Caputo operators (see also [20-22]).

In the modern scientific world information technologies are widely used in various fields of science and engineering $[23,24]$. In application of differential equations the numerical methods play an important role. Different methods are used for the numerical solution of differential, integral and integro-differential equations [25-34]. In particular, the book [28] is devoted to Chebyshev and Fourier spectral methods and [30] tells us about polynomial approximations of solving differential equations. The work [35] is devoted to study of nonlinear Volterra integral equations with weakly singular kernels by generalized Jacobi Spectral-Galerkin method.

In the present paper we consider the questions of one-valued solvability and numerical realization for a Hilfer type fractional differential equation with nonlinear right-hand side and maxima. This equation we solve under initial value condition. Differential equations with maxima play an important role in solving control problems of the sale of goods and investment of manufacturing companies in a market economy [36]. In [37] it is justified that the theoretical study of differential equations with maxima is relevant.

We consider the Hilfer type fractional differential equation on a interval $\left(t_{0} ; T\right)$ :

$$
D^{\alpha, \gamma} x(t)+\omega x(t)=f\left(t, x(t), \max \left\{x(\theta) \mid \theta \in\left[q_{1} t ; q_{2} t\right]\right\}\right)
$$

under initial value condition

$$
\lim _{t \rightarrow t_{0}} J_{t_{0}+}^{1-\gamma} x(t)=x_{0}, \quad x(t)=\varphi(t), t \notin\left(t_{0}, T\right)
$$

where $f(t, u, \vartheta) \in C(\Omega), \varphi(t) \in C\left(\left[0 ; t_{0}\right] \cup[T ; \infty]\right), 0<\omega$ is real parameter, $x_{0}=$ const, $\Omega \equiv\left[t_{0} ; T\right] \times \mathbb{X} \times \mathbb{X}$, $0 \leq t_{0}, \mathbb{X} \subset \mathbb{R} \equiv(-\infty ; \infty), \mathbb{X}$ is closed set. Here

$$
D^{\alpha, \gamma}=J_{t_{0}+}^{\gamma-\alpha} \frac{d}{d t} J_{t_{0}+}^{1-\gamma}, \quad 0<\alpha \leq \gamma \leq 1
$$


is Hilfer operator and $J_{0+}^{\alpha}$ is the Riemann-Liouville integral operator, which is defined by the formula

$$
J_{t_{0}+}^{\alpha} \eta(t)=\frac{1}{\Gamma(\alpha)} \int_{t_{0}}^{t} \frac{\eta(s) d s}{(t-s)^{1-\alpha}}, \quad \alpha>0 .
$$

We set $0<q_{1}<q_{2}<\infty$ and understand that there are possible cases: 1) $0<q_{1}<q_{2}<1$; 2) $0<q_{1}<1$, $\left.1<q_{2}<\infty ; 3\right) 1<q_{1}<q_{2}<\infty$.

\section{Fractional integral equation}

Lemma. The solution of the differential equation (1) with initial value condition (2) is represented as follows

$$
\begin{gathered}
x(t)=\Im(t ; x) \equiv x_{0}\left(t-t_{0}\right)^{\gamma-1} E_{\alpha, \gamma}\left(-\omega\left(t-t_{0}\right)^{\alpha}\right)+ \\
+\int_{t_{0}}^{t}(t-s)^{\alpha-1} E_{\alpha, \alpha}\left(-\omega(t-s)^{\alpha}\right) f\left(s, x(s), \max \left\{x(\theta) \mid \theta \in\left[q_{1} s ; q_{2} s\right]\right\}\right) d s,
\end{gathered}
$$

where $E_{\alpha, \gamma}(z)$ is Mittag-Leffler function and has the form [2, vol. 1, 269-295]

$$
E_{\alpha, \gamma}(z)=\sum_{k=0}^{\infty} \frac{z^{k}}{\Gamma(\alpha k+\gamma)}, \quad z, \alpha, \gamma \in \mathbb{R}>0 .
$$

Proof. We rewrite the differential equation (1) in the form

$$
J_{t_{0}+}^{\gamma-\alpha} D_{t_{0}+}^{\gamma} x(t)=-\omega x(t)+f(t, \cdot),
$$

where $f(t, \cdot)=f\left(t, x(t), \max \left\{x(\theta) \mid \theta \in\left[q_{1} t ; q_{2} t\right]\right\}\right)$.

Applying the operator $J_{t_{0}+}^{\alpha}$ to both sides of this equation, taking into account the linearity of this operator and the formula $[6]$

we obtain

$$
J_{t_{0}+}^{\gamma} D_{t_{0}+}^{\gamma} x(t)=x(t)-\left.\frac{1}{\Gamma(\gamma)} J_{t_{0}+}^{1-\gamma} x(t)\right|_{t=t_{0}+}\left(t-t_{0}\right)^{\gamma-1}
$$

$$
x(t)=\frac{x_{0}}{\Gamma(\gamma)}\left(t-t_{0}\right)^{\gamma-1}+J_{t_{0}+}^{\alpha} f(t, \cdot)-\omega J_{t_{0}+}^{\alpha} x(t) .
$$

Using the lemma from [38], we represent the solution of equation (4) in the form

$$
\begin{gathered}
x(t)=\frac{x_{0}}{\Gamma(\gamma)}\left(t-t_{0}\right)^{\gamma-1}+J_{t_{0}+}^{\alpha} f(t, \cdot)- \\
-\omega \int_{t_{0}}^{t}(t-s)^{\alpha-1} E_{\alpha, \alpha}\left(-\omega(t-s)^{\alpha}\right)\left[\frac{x_{0}}{\Gamma(\gamma)}\left(s-t_{0}\right)^{\gamma-1}+J_{t_{0}+}^{\alpha} f(s, \cdot)\right] d s .
\end{gathered}
$$

We rewrite the representation (5) as the sum of two expressions:

$$
\begin{gathered}
I_{1}(t)=x_{0}\left[\frac{\left(t-t_{0}\right)^{\gamma-1}}{\Gamma(\gamma)}-\frac{\omega}{\Gamma(\gamma)} \int_{t_{0}}^{t}(t-s)^{\alpha-1} E_{\alpha, \alpha}\left(-\omega(t-s)^{\alpha}\right)\left(s-t_{0}\right)^{\gamma-1} d s\right], \\
I_{2}(t)=J_{t_{0}+}^{\alpha} f(t, \cdot)-\omega \int_{t_{0}}^{t}(t-s)^{\alpha-1} E_{\alpha, \alpha}\left(-\omega(t-s)^{\alpha}\right) J_{t_{0}+}^{\alpha} f(s, \cdot) d s .
\end{gathered}
$$

We apply the following representations [2, vol. 1, 269-295]

$$
E_{\alpha, \gamma}(z)=\frac{1}{\Gamma(\gamma)}+z E_{\alpha, \gamma+\alpha}(z), \quad \alpha>0, \quad \gamma>0
$$




$$
\frac{1}{\Gamma(k)} \int_{t_{0}}^{z}(z-t)^{k-1} E_{\alpha, \gamma}\left(-\omega t^{\alpha}\right) t^{\gamma-1} d t=z^{\gamma+k-1} E_{\alpha, \gamma+k}\left(-\omega z^{\alpha}\right), \quad k>0, \quad \gamma>0 .
$$

Then for the integral (6) we obtain the representation

$$
I_{1}(t)=x_{0}\left(t-t_{0}\right)^{\gamma-1} E_{\alpha, \gamma}\left(-\omega\left(t-t_{0}\right)^{\alpha}\right) .
$$

The integral in (7) is easily transformed to the form

$$
\begin{gathered}
\int_{t_{0}}^{t}(t-\xi)^{\alpha-1} E_{\alpha, \alpha}\left(-\omega(t-\xi)^{\alpha}\right) J_{t_{0}+}^{\alpha} f(\xi, \cdot) d \xi= \\
=\frac{1}{\Gamma(\alpha)} \int_{t_{0}}^{t}(t-\xi)^{\alpha-1} E_{\alpha, \alpha}\left(-\omega(t-\xi)^{\alpha}\right) d \xi \int_{t_{0}}^{\xi}(\xi-s)^{\alpha-1} f(s, \cdot) d s= \\
=\frac{1}{\Gamma(\alpha)} \int_{t_{0}}^{t} f(s, \cdot) d s \int_{s}^{t}(t-\xi)^{\alpha-1}(\xi-s)^{\alpha-1} E_{\alpha, \alpha}\left(-\omega(t-\xi)^{\alpha}\right) d \xi .
\end{gathered}
$$

Taking (9) into account the second integral in the last equality of (11) can be written as

$$
\int_{s}^{t}(t-\xi)^{\alpha-1}(\xi-s)^{\alpha-1} E_{\alpha, \alpha}\left(-\omega(t-\xi)^{\alpha}\right) d \xi=\Gamma(\alpha)(t-\xi)^{2 \alpha-1} E_{\alpha, 2 \alpha}\left(-\omega(t-\xi)^{\alpha}\right) .
$$

Then, taking into account (8), we represent (7) in the following form

$$
I_{2}(t)=\int_{t_{0}}^{t}(t-\xi)^{\alpha-1} E_{\alpha, \alpha}\left(-\omega(t-\xi)^{\alpha}\right) f(\xi, \cdot) d \xi .
$$

Substituting (10) and (12) into the sum $x(t)=I_{1}(t)+I_{2}(t)$, we obtain (3). The lemma is proved.

\section{Existence and uniqueness of solution}

Theorem. Let the following two conditions be satisfied:

1) $\max _{t_{0} \leq t \leq T}|f(t, x, y)| \leq M=$ const $<\infty$;

2) $\left|f\left(t, x_{1}, y_{1}\right)-f\left(t, x_{2}, y_{2}\right)\right| \leq L\left(\left|x_{1}-x_{2}\right|+\left|y_{1}-y_{2}\right|\right), \quad 0<L=$ const $<\infty$.

Then there exists a unique solution of the initial value problem (1), (2) in the space of continuous functions $C\left(t_{0} ; T\right)$, which can be found by the method of successive approximations:

$$
\left\{\begin{array}{l}
x_{0}(t)=G(t) \\
x_{k+1}(t)=\Im\left(t ; x_{k}\right), \quad k=0,1,2, \ldots
\end{array}\right.
$$

where $G(t)=x_{0}\left(t-t_{0}\right)^{\gamma-1} E_{\alpha, \gamma}\left(-\omega\left(t-t_{0}\right)^{\alpha}\right)$.

Proof. Mittag-Leffler function $E_{\alpha, \gamma}(z)$ has the following property [39]: we assume that $0<\alpha<2, \gamma$ is real constant and $\arg z=\pi$. Then there holds

$$
\left|E_{\alpha, \gamma}(z)\right| \leq \frac{A}{1+|z|},
$$

where $A$ is positive constant and does not dependent on $z$. Then it is not difficult to see that from the approximations (13) we obtain that there following estimate holds

$$
\left|\left(t-t_{0}\right)^{1-\gamma} x_{0}(t)\right| \leq\left|x_{0}\right| \cdot\left|E_{\alpha, \gamma}\left(-\omega\left(t-t_{0}\right)^{\alpha}\right)\right| \leq\left|x_{0}\right| \cdot C_{0},
$$

where $\left|E_{\alpha, \alpha}\left(-\omega(t-s)^{\alpha}\right)\right| \leq C_{0}$. 
By virtue of first condition of the theorem and estimate (14), from approximations (13) we obtain

$$
\begin{gathered}
\left|x_{1}(t)-x_{0}(t)\right| \leq \\
\leq \int_{t_{0}}^{t}\left|(t-s)^{\alpha-1} E_{\alpha, \alpha}\left(-\omega(t-s)^{\alpha}\right) f\left(s, x_{0}(s), \max \left\{x_{0}(\theta) \mid \theta \in\left[q_{1} s ; q_{2} s\right]\right\}\right)\right| d s \leq \\
\leq M \cdot C_{0}\left|x_{0}\right| \int_{t_{0}}^{t}(t-s)^{\alpha-1} d s \leq \frac{\left|x_{0}\right|}{\alpha} M \cdot C_{0} \cdot\left(t-t_{0}\right)^{\alpha} .
\end{gathered}
$$

We continue the Picard iteration process for the integral equation (3) according to the approximations (13). Then, by virtue of conditions of the theorem and taking the estimate (15) into account, we derive

$$
\begin{gathered}
\left|x_{2}(t)-x_{1}(t)\right| \leq \int_{t_{0}}^{t} \mid(t-s)^{\alpha-1} E_{\alpha, \alpha}\left(-\omega(t-s)^{\alpha}\right)\left[f\left(s, x_{1}(s), \max \left\{x_{1}(\theta) \mid \theta \in\left[q_{1} s ; q_{2} s\right]\right\}\right)-\right. \\
\left.-f\left(s, x_{0}(s), \max \left\{x_{0}(\theta) \mid \theta \in\left[q_{1} s ; q_{2} s\right]\right\}\right)\right]\left|d s \leq L \int_{t_{0}}^{t}\right|(t-s)^{\alpha-1} E_{\alpha, \alpha}\left(-\omega(t-s)^{\alpha}\right) \mid\left[\left|x_{1}(s)-x_{0}(s)\right|+\right. \\
\left.+\left|\max \left\{x_{1}(\theta) \mid \theta \in\left[q_{1} s ; q_{2} s\right]\right\}-\max \left\{x_{0}(\theta) \mid \theta \in\left[q_{1} s ; q_{2} s\right]\right\}\right|\right] d s \leq \\
\leq 2 C_{0} L \int_{t_{0}}^{t}(t-s)^{\alpha-1}\left|x_{1}(s)-x_{0}(s)\right| d s \leq \frac{2\left|x_{0}\right|}{\alpha} M \cdot C_{0}^{2} L \int_{t_{0}}^{t}(t-s)^{\alpha-1}\left(s-t_{0}\right)^{\alpha} d s .
\end{gathered}
$$

By the changing the argument as $s=t_{0}+\left(t-t_{0}\right) \tau$, from the last estimate we obtain

$$
\begin{gathered}
\left|x_{2}(t)-x_{1}(t)\right| \leq \frac{2\left|x_{0}\right|}{\alpha} M \cdot C_{0}^{2} L \int_{t_{0}}^{t}\left(t-t_{0}\right)^{\alpha-1}(1-\tau)^{\alpha-1}\left(t-t_{0}\right)^{\alpha} \tau^{\alpha}\left(t-t_{0}\right) d \tau \leq \\
\leq \frac{2 \Gamma^{2}(\alpha)}{\Gamma(2 \alpha+1)}\left|x_{0}\right| M \cdot L \cdot\left[C_{0} \cdot\left(t-t_{0}\right)^{\alpha}\right]^{2} .
\end{gathered}
$$

Analogously, taking the estimate (16) into account, for the next difference we derive

$$
\begin{gathered}
\left|x_{3}(t)-x_{2}(t)\right| \leq L \int_{t_{0}}^{t}\left|(t-s)^{\alpha-1} E_{\alpha, \alpha}\left(-\omega(t-s)^{\alpha}\right)\right|\left[\left|x_{2}(s)-x_{1}(s)\right|+\right. \\
\left.+\left|\max \left\{x_{2}(\theta) \mid \theta \in\left[q_{1} s ; q_{2} s\right]\right\}-\max \left\{x_{1}(\theta) \mid \theta \in\left[q_{1} s ; q_{2} s\right]\right\}\right|\right] d s \leq \\
\leq 2 C_{0} L \int_{t_{0}}^{t}(t-s)^{\alpha-1}\left|x_{2}(s)-x_{1}(s)\right| d s \leq \\
\leq \frac{\Gamma^{2}(\alpha)}{\Gamma(2 \alpha+1)}\left|x_{0}\right| M \cdot(2 L)^{2} \cdot C_{0}^{3} \int_{t_{0}}^{t}(t-s)^{\alpha-1}\left(s-t_{0}\right)^{2 \alpha} d s \leq \\
\leq \frac{\Gamma^{3}(\alpha)}{\Gamma(3 \alpha+1)} \cdot\left|x_{0}\right| \cdot M \cdot(2 L)^{2} \cdot\left[C_{0} \cdot\left(t-t_{0}\right)^{\alpha}\right]^{3} .
\end{gathered}
$$

Continuing the estimation processes (14)-(17) for arbitrary difference we obtain

$$
\left|x_{n}(t)-x_{n-1}(t)\right| \leq \frac{\Gamma^{n}(\alpha)}{\Gamma(n \alpha+1)} \cdot\left|x_{0}\right| \cdot M \cdot(2 L)^{n-1}\left[C_{0} \cdot\left(t-t_{0}\right)^{\alpha}\right]^{n} .
$$


For the absolute value of difference $\left|x_{n}(t)-x_{n-1}(t)\right|$ we show that $\sum_{n=1}^{\infty}\left|x_{n}(t)-x_{n-1}(t)\right|<\infty$ in the space $C\left(t_{0} ; T\right)$. So, we denote the right-hand side of (18) as

$$
a_{n}=\frac{\Gamma^{n}(\alpha)}{\Gamma(n \alpha+1)} \cdot(2 L)^{n-1}\left[C_{0} \cdot\left(t-t_{0}\right)^{\alpha}\right]^{n}
$$

and we put

$$
a_{n+1}=\frac{\Gamma^{n+1}(\alpha)}{\Gamma((n+1) \alpha+1)} \cdot(2 L)^{n}\left[C_{0} \cdot\left(t-t_{0}\right)^{\alpha}\right]^{n+1} .
$$

Then we consider the following limit

$$
\lim _{n \rightarrow \infty} \frac{a_{n+1}}{a_{n}}=2 L \cdot \Gamma(\alpha) \cdot C_{0} \cdot\left(t-t_{0}\right)^{\alpha} \lim _{n \rightarrow \infty} \frac{\Gamma(n \alpha+1)}{\Gamma((n+1) \alpha+1)} .
$$

Taking known formula [40]

$$
\frac{\Gamma(z+a)}{\Gamma(z+b)}=z^{a-b}\left[1+\frac{(a-b)(a-b-1)}{2 z}+O\left(z^{-2}\right)\right]
$$

into account, we obtain

$$
\begin{aligned}
\lim _{n \rightarrow \infty} \frac{\Gamma(n \alpha+1)}{\Gamma((n \alpha+\alpha+1)} & =\lim _{n \rightarrow \infty}(n \alpha)^{1-\alpha-1}\left[1+\frac{(1-\alpha-1)(1-\alpha-1-1)}{2 n \alpha}+O(n \alpha)^{-2}\right]= \\
& =\frac{1}{\alpha^{\alpha}} \lim _{n \rightarrow \infty} \frac{1}{n^{\alpha}}\left[1+\frac{\alpha(1+\alpha)}{2 n \alpha}+O(n \alpha)^{-2}\right]=0 .
\end{aligned}
$$

Consequently, for (19) we have

$$
\begin{gathered}
\lim _{n \rightarrow \infty} \frac{a_{n+1}}{a_{n}}=2 L \cdot \Gamma(\alpha) \cdot C_{0} \cdot\left(t-t_{0}\right)^{\alpha} \cdot \lim _{n \rightarrow \infty} \frac{\Gamma(n \alpha+1)}{\Gamma((n+1) \alpha+1)}= \\
=2 \Gamma(\alpha) \cdot L \cdot C_{0} \cdot\left(t-t_{0}\right)^{\alpha} \cdot \frac{1}{\alpha^{\alpha}} \lim _{n \rightarrow \infty} \frac{1}{n^{\alpha}}\left[1+\frac{\alpha(1+\alpha)}{2 n \alpha}+O(n \alpha)^{-2}\right]=0 .
\end{gathered}
$$

Hence, according to d'Alembert's convergence criterion of series, we have

$$
\sum_{n=1}^{\infty}\left|x_{n}(t)-x_{n-1}(t)\right| \leq \sum_{n=1}^{\infty} \frac{\Gamma^{n}(\alpha)}{\Gamma(n \alpha+1)} \cdot C_{0}^{n} \cdot(2 L)^{n-1}\left(t-t_{0}\right)^{n \alpha}<\infty
$$

for all $t \geq t_{0}$. Since we consider the solution of the integral equation (3) in the space of continuous functions $C\left(t_{0} ; T\right)$, it follows from (20) that the sequence of functions $\left\{x_{k}(t)\right\}_{k=1}^{\infty}$ converges absolutely and uniformly to solution of the integral equation (3) with respect to argument $t$. Hence implies the existence of a solution of the problem (1), $(2)$ on the interval $\left(t_{0} ; T\right)$. Now we show the uniqueness of this solution. Assuming that the integral equation (3) has two different solutions $x(t)$ and $y(t)$ on the interval $\left(t_{0} ; T\right)$, we obtain the following integral inequality

$$
|x(t)-y(t)| \leq 2 L \int_{t_{0}}^{t}\left|(t-s)^{\alpha-1} E_{\alpha, \alpha}\left(-\omega(t-s)^{\alpha}\right)\right| \cdot|x(s)-y(s)| d s .
$$

Applying Gronwall-Bellman inequality to estimate (21), we obtain that $|x(t)-y(t)| \equiv 0$ for all $t \in\left(t_{0} ; T\right)$. Therefore, the Cauchy problem (1), (2) has a unique solution on the interval $\left(t_{0} ; T\right)$. The theorem is proved. 


\section{The generalized Jakobi-Galerkin method}

Now, to the problem (1), (2) we apply the generalized Jacobi-Galerkin method as a numerical realization of solution (3). This solution (3) is nonlinear Volterra type fractional integral equation. On the interval $(-1 ; 1)$ for the given numbers $\beta_{1}, \beta_{2}>-1$ we consider standard Jacobi polynomial $J_{n}^{\left(\beta_{1}, \beta_{2}\right)}(\xi)$ of degree $n$ with weight function $\Lambda^{\left(\beta_{1}, \beta_{2}\right)}(\xi)=(1-\xi)^{\beta_{1}}(1+\xi)^{\beta_{2}}$. For the standard Jacobi polynomial the following relation is true

$$
\int_{-1}^{1} J_{n}^{\left(\beta_{1}, \beta_{2}\right)}(\xi) J_{m}^{\left(\beta_{1}, \beta_{2}\right)}(\xi) \Lambda^{\left(\beta_{1}, \beta_{2}\right)}(\xi) d \xi=\gamma_{m}^{\left(\beta_{1}, \beta_{2}\right)} \delta_{m, n}
$$

where $\delta_{m, n}$ is the Kronecker function and

$$
\gamma_{m}^{\left(\beta_{1}, \beta_{2}\right)}(\xi)= \begin{cases}\frac{2^{\beta_{1}+\beta_{2}+1} \Gamma\left(\beta_{1}+1\right) \Gamma\left(\beta_{2}+1\right)}{\Gamma\left(\beta_{1}+\beta_{2}+2\right)}, & m=0 \\ \frac{2^{\beta_{1}+\beta_{2}+1} \Gamma\left(m+\beta_{1}+1\right) \Gamma\left(m+\beta_{2}+1\right)}{\left(2 m+\beta_{1}+\beta_{2}+1\right) m ! \Gamma\left(m+\beta_{1}+\beta_{2}+2\right)}, & m \geq 1\end{cases}
$$

From $(22)$ we note that the set of standard Jacobi polynomial $J_{n}^{\left(\beta_{1}, \beta_{2}\right)}(\xi)$ is a complete orthogonal system in the space $L_{\Lambda\left(\beta_{1}, \beta_{2}\right)}^{2}(-1 ; 1)$ with weight function $\Lambda^{\left(\beta_{1}, \beta_{2}\right)}(\xi)$. In particular, $J_{0}^{\left(\beta_{1}, \beta_{2}\right)}(\xi)=1$.

The shifted Jacobi polynomial of variable $t$ and degree $n$ is defined by the following formula

$$
\tilde{J}_{n}^{\left(\beta_{1}, \beta_{2}\right)}(t)=J_{n}^{\left(\beta_{1}, \beta_{2}\right)}\left(\frac{2\left(t-t_{0}\right)}{T-t_{0}}-1\right), \quad t \in\left(t_{0} ; T\right) .
$$

We note that the set of shifted Jacobi polynomial $\tilde{J}_{n}^{\left(\beta_{1}, \beta_{2}\right)}(t)$ is a complete orthogonal system with weight function $\Lambda_{T}^{\left(\beta_{1}, \beta_{2}\right)}(t)=\left(T-t+t_{0}\right)^{\beta_{1}}\left(t-t_{0}\right)^{\beta_{2}}$ in the space $L_{\Lambda\left(\beta_{1}, \beta_{2}\right)}^{2}\left(t_{0} ; T\right)$ and by the aid of (23) we have the analogue of the $(22)$

$$
\int_{t_{0}}^{T} \tilde{J}_{n}^{\left(\beta_{1}, \beta_{2}\right)}(t) \tilde{J}_{m}^{\left(\beta_{1}, \beta_{2}\right)}(t) \Lambda_{T}^{\left(\beta_{1}, \beta_{2}\right)}(t) d t=\left(\frac{T+t_{0}}{2}\right)^{\beta_{1}+\beta_{2}+1} \gamma_{m}^{\left(\beta_{1}, \beta_{2}\right)}(t) \delta_{m, n} .
$$

For any integer $N \geq 0$ we denote by $\left\{\xi_{j}^{\left(\beta_{1}, \beta_{2}\right)}, \eta_{j}^{\left(\beta_{1}, \beta_{2}\right)}\right\}_{j=0}^{N}$ the nodes and the corresponding Christoffel numbers of the standard Jacobi-Gauss interpolation on the interval $(-1 ; 1)$. By the $\tilde{P}_{N}\left(t_{0} ; T\right)$ we denote the set of polynomials of degree at most $N$ on the interval $\left(t_{0} ; T\right)$ and by the $t_{j}^{\left(\beta_{1}, \beta_{2}\right)}$ we denote the shifted Jacobi-Gauss quadrature nodes on the interval $\left(t_{0} ; T\right)$

$$
t_{j}^{\left(\beta_{1}, \beta_{2}\right)}=\frac{T-t_{0}}{2}\left(\xi_{j}^{\left(\beta_{1}, \beta_{2}\right)}+1\right)+t_{0}, \quad 0 \leq j \leq N .
$$

By virtue of the property of the standard Jacobi-Gauss quadrature it's implied that for any $\phi(t) \in \tilde{P}_{2 N+1}\left(t_{0} ; T\right)$ we have

$$
\int_{t_{0}}^{T} \phi(t) \Lambda_{T}^{\left(\beta_{1}, \beta_{2}\right)}(t) d t=\left(\frac{T+t_{0}}{2}\right)^{\beta_{1}+\beta_{2}+1} \sum_{j=0}^{N} \phi\left(t_{j}^{\left(\beta_{1}, \beta_{2}\right)}\right) \eta_{j}^{\left(\beta_{1}, \beta_{2}\right)}
$$

By virtue of (25) from (24), we have for any $0 \leq m+n \leq 2 N+1$,

$$
\sum_{j=0}^{N} \tilde{J}_{m}^{\left(\beta_{1}, \beta_{2}\right)}\left(t_{j}^{\left(\beta_{1}, \beta_{2}\right)}\right) \tilde{J}_{n}^{\left(\beta_{1}, \beta_{2}\right)}\left(t_{j}^{\left(\beta_{1}, \beta_{2}\right)}\right) \eta_{j}^{\left(\beta_{1}, \beta_{2}\right)}=\gamma_{m}^{\left(\beta_{1}, \beta_{2}\right)} \delta_{m, n}
$$

By the aid of shifted Jacobi polynomial $\tilde{J}_{n}^{\left(\beta_{1}, \beta_{2}\right)}(t)$ we define the shifted generalized Jacobi function of degree $n$ as (see [41])

$$
P_{n}^{\left(\beta_{1}, \beta_{2}\right)}(t)=t^{\beta_{2}} \tilde{J}_{n}^{\left(\beta_{1}, \beta_{2}\right)}(t), \quad \beta_{1}, \beta_{2}>-1, \quad t \in\left(t_{0} ; T\right) .
$$


By virtue of (24) and (26), we see that

$$
\int_{t_{0}}^{T} P_{n}^{\left(\beta_{1}, \beta_{2}\right)}(t) P_{m}^{\left(\beta_{1}, \beta_{2}\right)}(t) \Lambda_{T}^{\left(\beta_{1},-\beta_{2}\right)}(t) d t=\left(\frac{T+t_{0}}{2}\right)^{\beta_{1}+\beta_{2}+1} \gamma_{m}^{\left(\beta_{1}, \beta_{2}\right)} \delta_{m, n} .
$$

By virtue of (25), for any $\varphi(t)=t^{2 \beta_{2}} \phi(t)$ we have

$$
\int_{t_{0}}^{T} \varphi(t) \Lambda_{T}^{\left(\beta_{1},-\beta_{2}\right)}(t) d t=\left(\frac{T+t_{0}}{2}\right)^{\beta_{1}+\beta_{2}+1} \sum_{j=0}^{N}\left(t_{j}^{\left(\beta_{1}, \beta_{2}\right)}\right)^{-2 \beta_{2}} \varphi\left(t_{j}^{\left(\beta_{1}, \beta_{2}\right)}\right) \eta_{j}^{\left(\beta_{1}, \beta_{2}\right)} .
$$

By the aid of (27) we introduce the inner product in $L_{\Lambda_{T}^{\left(\beta_{1},-\beta_{2}\right)}}^{2}(0 ; T)$ as

$$
\langle f, g\rangle_{\Lambda_{T}^{\left(\beta_{1},-\beta_{2}\right)}}=\left(\frac{T+t_{0}}{2}\right)^{\beta_{1}+\beta_{2}+1} \sum_{j=0}^{N}\left(t_{j}^{\left(\beta_{1}, \beta_{2}\right)}\right)^{-2 \beta_{2}} f\left(t_{j}^{\left(\beta_{1}, \beta_{2}\right)}\right) g\left(t_{j}^{\left(\beta_{1}, \beta_{2}\right)}\right) \eta_{j}^{\left(\beta_{1}, \beta_{2}\right)} .
$$

We need also to introduce finite $N$-dimensional fractional polynomial space [41]

$$
\tilde{F}_{N}^{\left(\beta_{2}\right)}\left(t_{0} ; T\right)=\left\{t^{\beta_{2}} \psi(t): \psi(t) \in \tilde{P}_{N}^{\left(\beta_{1}, \beta_{2}\right)}\left(t_{0} ; T\right)\right\}=\operatorname{span}\left\{P_{n}^{\left(\beta_{1}, \beta_{2}\right)}(t): 0 \leq n \leq N\right\} .
$$

Then we note that for any $\phi, \psi \in \tilde{F}_{N}^{\left(\beta_{2}\right)}\left(t_{0} ; T\right)$ hold the equalities

$$
(\phi, \psi)_{\Lambda_{T}^{\left(\beta_{1},-\beta_{2}\right)}}=\langle\phi, \psi\rangle_{\Lambda_{T}^{\left(\beta_{1},-\beta_{2}\right)}} .
$$

Now in integral equation (3) we make variable transformation $s=\frac{t \tau}{T}, \tau \in\left(t_{0} ; T\right)$. Then the we describe integral equation (3) as

$$
\begin{aligned}
x(t)=\Im(t ; x) \equiv & G(t)+V x(t)=G(t)+\left(\frac{t}{T}\right)^{\alpha} \int_{t_{0}}^{t}(T-\tau)^{\alpha-1} E_{\alpha, \alpha}\left(-\omega\left(\frac{t}{T}\right)^{\alpha}(T-\tau)^{\alpha}\right) \times \\
& \times f\left(\frac{t \tau}{T}, x\left(\frac{t \tau}{T}\right), \max \left\{x(\theta) \mid \theta \in\left[\frac{q_{1} t \tau}{T} ; \frac{q_{2} t \tau}{T}\right]\right\}\right) d \tau .
\end{aligned}
$$

For the Hilfer fractional operator's order $0<\alpha<1$ we denote $\alpha-1=-\mu$, where $0<\mu=$ const Then for $U, \varphi \in \tilde{F}_{N}^{(1-\mu)}\left(t_{0} ; T\right)$ we apply the generalized Jacobi-Galerkin method to equation (28):

$$
(U, \varphi)_{\Lambda_{T}^{(-\mu, \mu-1)}}=(G, \varphi)_{\Lambda_{T}^{(-\mu, \mu-1)}}+(V U, \varphi)_{\Lambda_{T}^{(-\mu, \mu-1)}}
$$

We set

$$
U(t)=\sum_{m=0}^{N} x_{m}(t) P_{m}^{(-\mu, 1-\mu)}(t), \quad \varphi(t)=P_{n}^{(-\mu, 1-\mu)}(t), \quad 0 \leq m, n \leq N .
$$

Then for (29) we have

$$
\begin{gathered}
\sum_{m=0}^{N} x_{m}(t)\left(P_{m}^{(-\mu, 1-\mu)}(t), P_{n}^{(-\mu, 1-\mu)}(t)\right)_{\Lambda_{T}^{(-\mu, \mu-1)}}= \\
=\left(G(t), P_{n}^{(-\mu, 1-\mu)}(t)\right)_{\Lambda_{T}^{(-\mu, \mu-1)}}+\left(V U(t), P_{n}^{(-\mu, 1-\mu)}(t)\right)_{\Lambda_{T}^{(-\mu, \mu-1)}} .
\end{gathered}
$$

Hence, we come to nonlinear system

$$
\bar{B} \bar{x}=\bar{G}+\bar{\vartheta}(\bar{x})
$$

after introducing designations:

$$
\begin{aligned}
& \bar{x}=\left(x_{0}, x_{1}, \ldots, \bar{x}_{N}\right)^{T}, \quad B=\left(b_{n m}\right)_{0 \leq n m \leq N}, \\
& b_{n m}=\left(P_{m}^{(-\mu, 1-\mu)}(t), P_{n}^{(-\mu, 1-\mu)}(t)\right)_{\Lambda_{T}^{(-\mu, \mu-1)}}=\left(\frac{T+t_{0}}{2}\right)^{2-2 \mu} \gamma_{m}^{(-\mu, 1-\mu)} \delta_{m, n}, \\
& \bar{G}=\left(G_{0}, G_{1}, \ldots, G_{N}\right)^{T}, G_{n}(t)=\left(G(t), P_{n}^{(-\mu, 1-\mu)}(t)\right)_{\Lambda_{T}^{(-\mu, \mu-1)}}, \\
& \bar{\vartheta}(\bar{x})=\left(\vartheta_{0}, \vartheta_{1}, \ldots, \vartheta_{N}\right)^{T}, \vartheta_{n}(x)=\left(V U(t), P_{n}^{(-\mu, 1-\mu)}(t)\right)_{\Lambda_{T}^{(-\mu, \mu-1)}},
\end{aligned}
$$

where by $\left(u_{0}, u_{1}, \ldots, u_{N}\right)^{T}$ we denoted the transposition of the matrix $\left(u_{0}, u_{1}, \ldots, u_{N}\right)$. 
We use the quadrature formula

$$
\langle f, g\rangle_{\Lambda_{T}^{\left(\beta_{1},-\beta_{2}\right)}}=\left(\frac{T+t_{0}}{2}\right)^{\beta_{1}+\beta_{2}+1} \sum_{j=0}^{N}\left(t_{j}^{\left(\beta_{1}, \beta_{2}\right)}\right)^{-2 \beta_{2}} f\left(t_{j}^{\left(\beta_{1}, \beta_{2}\right)}\right) g\left(t_{j}^{\left(\beta_{1}, \beta_{2}\right)}\right) \eta_{j}^{\left(\beta_{1}, \beta_{2}\right)}
$$

to obtain approximate formulas:

$$
\begin{gathered}
G_{n}(t) \approx\left\langle G(t), P_{n}^{(-\mu, 1-\mu)}(t)\right\rangle_{\Lambda_{T}^{(-\mu, \mu-1)}}= \\
=\left(\frac{T+t_{0}}{2}\right)^{2-2 \mu} \sum_{j=0}^{N}\left(t_{j}^{(-\mu, 1-\mu)}\right)^{2 \mu-2} G\left(t_{j}^{(-\mu, 1-\mu)}\right) P_{n}^{(-\mu, 1-\mu)}\left(t_{j}^{(-\mu, 1-\mu)}\right) \eta_{j}^{(-\mu, 1-\mu)}, \\
\bar{\vartheta}(\bar{x}) \approx \frac{\left(T+t_{0}\right)^{2-2 \mu}}{2^{2-2 \mu}} \sum_{i, j=0}^{N}\left(\frac{t_{i}^{(-\mu, 1-\mu)}}{T}\right)^{1-\mu}(T-\tau)^{-\mu} E_{1-\mu, 1-\mu}\left(-\omega\left(\frac{t_{i}^{(-\mu, 1-\mu)}}{T}\right)^{1-\mu}(T-\tau)^{1-\mu}\right) \times \\
\times f\left(t_{i j}, U\left(t_{i j}\right), \max \left\{U(\theta) \mid \theta \in\left[q_{1} \cdot t_{i j} ; q_{2} \cdot t_{i j}\right]\right\}\right) \times \\
\times P_{n}^{(-\mu, 1-\mu)}\left(t_{i}^{(-\mu, 1-\mu)}\right) \eta_{i}^{(-\mu, 1-\mu)} \eta_{j}^{(-\mu, 0)},
\end{gathered}
$$

where $t_{i j}=\frac{t_{i}^{(-\mu, 1-\mu)} t_{j}^{(-\mu, 0)}}{T}$.

In approximately solving the system (30) one can use the Newton iterative method.

\section{Illustrarive examples}

As an example, we consider the simple equation of the form

$$
D_{0+}^{\alpha, \beta} u(t)=\lambda u(t)+f(t), \quad t \in(0 ; T)
$$

with initial value condition

$$
\lim _{t \rightarrow+0} J_{0+}^{1-\gamma} u(t)=u_{0}
$$

The solution of this problem has the form

$$
u(t)=u_{0} t^{\gamma-1} E_{\alpha, \gamma}\left(\lambda t^{\alpha}\right)+\int_{0}^{t}(t-s)^{\alpha-1} E_{\alpha, \alpha}\left(\lambda(t-s)^{\alpha}\right) f(s) d s,
$$

where $\gamma=\alpha+\beta-\alpha \beta$.

Example 1. We consider cases $\alpha=\beta=\frac{1}{2}, f(t)=t^{\sigma}, \quad \sigma>-1$. Since $\gamma=\frac{1}{2}+\frac{1}{2}-\frac{1}{2} \cdot \frac{1}{2}=\frac{3}{4}$, from (33) we have

$$
u(t)=u_{0} t^{-\frac{1}{4}} E_{\frac{1}{2}, \frac{3}{4}}\left(\lambda t^{\frac{1}{2}}\right)+\int_{0}^{t}(t-s)^{-\frac{1}{2}} E_{\frac{1}{2}, \frac{1}{2}}\left(\lambda(t-s)^{\frac{1}{2}}\right) s^{\sigma} d s .
$$

Taking into account

$$
\frac{1}{\Gamma(\nu)} \int_{0}^{z}(z-t)^{\nu-1} E_{\alpha, \beta}\left(\lambda t^{\alpha}\right) t^{\beta-1} d t=z^{\beta+\nu-1} E_{\alpha, \beta+\nu}\left(\lambda z^{\alpha}\right), \nu>0, \quad \beta>0,
$$

we calculate the integral in (34):

$$
\int_{0}^{t}(t-s)^{-\frac{1}{2}} E_{\frac{1}{2}, \frac{1}{2}}\left(\lambda(t-s)^{\frac{1}{2}}\right) s^{\sigma} d s=\Gamma(\sigma+1) t^{\frac{1}{2}+\sigma} E_{\frac{1}{2}, \frac{3}{2}+\sigma}\left(\lambda t^{\frac{1}{2}}\right) .
$$


Substituting (35) into (34), we obtain

$$
u(t)=\frac{u_{0}}{\sqrt[4]{t}} E_{\frac{1}{2}, \frac{3}{4}}(\lambda \sqrt{t})+\Gamma(\sigma+1) t^{\sigma} \sqrt{t} E_{\frac{1}{2}, \frac{3}{2}+\sigma}(\lambda \sqrt{t}) .
$$

In particular case, when $\sigma=0$, from (36) yields

$$
u(t)=\frac{u_{0}}{\sqrt[4]{t}} E_{\frac{1}{2}, \frac{3}{4}}(\lambda \sqrt{t})+\sqrt{t} E_{\frac{1}{2}, \frac{3}{2}}(\lambda \sqrt{t}) .
$$

Taking into account

$$
E_{\alpha, \mu}(z)=\frac{1}{\Gamma(\mu)}+z E_{\alpha, \alpha+\mu}(z), \quad \alpha>0, \quad \mu>0,
$$

we obtain

$$
\sqrt{t} E_{\frac{1}{2}, \frac{3}{2}}(\lambda \sqrt{t})=\frac{1}{\lambda} E_{\frac{1}{2}, 1}(\lambda \sqrt{t})-\frac{1}{\lambda} .
$$

Therefore (37) takes form

$$
u(t)=\frac{u_{0}}{\sqrt[4]{t}} E_{\frac{1}{2}, \frac{3}{4}}(\lambda \sqrt{t})+\frac{1}{\lambda} E_{\frac{1}{2}, 1}(\lambda \sqrt{t})-\frac{1}{\lambda} .
$$

Since $E_{\frac{1}{2}, 1}(z)=\cosh \sqrt{z}$, we present the solution as

$$
u(t)=\frac{u_{0}}{\sqrt[4]{t}} E_{\frac{1}{2}, \frac{3}{4}}(\lambda \sqrt{t})+\frac{1}{\lambda}[\cosh (\sqrt{\lambda \sqrt{t}})-1] .
$$

Example 2. The case of Caputo operator: $\alpha=\frac{1}{2}, \beta=1, f(t)=t^{\sigma}, \sigma>-1$.

Since $\gamma=\frac{1}{2}+1-\frac{1}{2} \cdot 1=1$, from (33) we have

$$
u(t)=u_{0} E_{\frac{1}{2}, 1}\left(\lambda t^{\frac{1}{2}}\right)+\int_{0}^{t}(t-s)^{-\frac{1}{2}} E_{\frac{1}{2}, \frac{1}{2}}\left(\lambda(t-s)^{\frac{1}{2}}\right) s^{\sigma} d s .
$$

Taking (35) into account, from (38) we obtain

$$
u(t)=u_{0} E_{\frac{1}{2}, 1}(\lambda \sqrt{t})+\Gamma(\sigma+1) t^{\sigma} \sqrt{t} E_{\frac{1}{2}, \frac{3}{2}+\sigma}(\lambda \sqrt{t}) .
$$

We are looking for real solutions. Since $E_{\frac{1}{2}, 1}(z)=\cosh \sqrt{z}$, then for $\lambda \geq 0$ we present the solution (39) as

$$
u(t)=u_{0} \cosh (\sqrt{\lambda \sqrt{t}})+\Gamma(\sigma+1) t^{\sigma} \sqrt{t} E_{\frac{1}{2}, \frac{3}{2}+\sigma}(\lambda \sqrt{t}) .
$$

For the cases $\sigma=0$ and $\lambda>0$ we have

$$
u(t)=u_{0} \cosh (\sqrt{\lambda \sqrt{t}})+\sqrt{t} E_{\frac{1}{2}, \frac{3}{2}}(\lambda \sqrt{t}) .
$$

Taking

$$
E_{\alpha, \mu}(z)=\frac{1}{\Gamma(\mu)}+z E_{\alpha, \alpha+\mu}(z), \quad \alpha>0, \quad \mu>0
$$

into account, the last summand easily presents as

$$
\sqrt{t} E_{\frac{1}{2}, \frac{3}{2}}(\lambda \sqrt{t})=\frac{1}{\lambda} E_{\frac{1}{2}, 1}(\lambda \sqrt{t})-\frac{1}{\lambda} .
$$

So, taking $E_{\frac{1}{2}, 1}(z)=\cosh \sqrt{z}$ into account, from representation (40) we obtain the simple form of solution

$$
u(t)=\frac{1}{\lambda}\left[\left(\lambda u_{0}+1\right) \cosh (\sqrt{\lambda \sqrt{t}})-1\right] .
$$

Now we consider an example of a nonlinear differential equation. 
Example 3. The equation

$$
{ }_{C} D_{0 t}^{\alpha} y(t)=\frac{1}{5} \Gamma(\alpha+1) t^{-2 \alpha}\left(y^{2}(t)+4 \cdot \max \left\{y^{2}(\theta) \mid \theta \in\left[\frac{1}{3} t ; t\right]\right\}\right), \quad \alpha>\frac{1}{2}
$$

on the interval $(0 ; 1)$ has a solution

$$
y(t)=t^{\alpha} .
$$

Indeed,

$$
\frac{1}{5} \Gamma(\alpha+1) t^{-2 \alpha}\left(y^{2}(t)+4 \cdot \max \left\{y^{2}(\theta) \mid \theta \in\left[\frac{1}{3} t ; t\right]\right\}\right)=\frac{1}{5} \Gamma(\alpha+1) t^{-2 \alpha}\left(5 t^{2 \alpha}\right)=\Gamma(\alpha+1)
$$

and

$$
{ }_{C} D_{0 t}^{\alpha} y(t)={ }_{C} D_{0 t}^{\alpha}\left(t^{\alpha}\right)=\frac{\Gamma(\alpha+1)}{\Gamma(\alpha+1-\alpha)} t^{\alpha-\alpha}=\frac{\Gamma(\alpha+1)}{\Gamma(\alpha+1-\alpha)}=\Gamma(\alpha+1) .
$$

From (43) and (44) we come to the conclusion that function (42) is a solution of the Caputo fractional differential equation $(41)$ on the interval $(0 ; 1)$.

Remark. The function (42) is not a solution of fractional differential equation $(41)$ on the semiaxis $(1 ; \infty)$. If we consider the solvability of the differential equation (41) on the entire positive semiaxis $\mathbb{R}^{+} \equiv(0 ; \infty)$, then this equation suffers a discontinuity of the first kind at the point $t=1$.

\section{Conclusion}

In this paper we consider the questions of unique solvability of initial value problem for a nonlinear fractional differential equation (1) with maxima on the given segment $\left(t_{0} ; T\right)$. We reduce this initial value problem to the fractional order nonlinear integral equation of Volterra type. Then we used the method of successive approximation and proved the theorem on existence and uniqueness of solution of the problem under consideration. We apply the generalized Jacobi-Galerkin method as a numerical realization of solution of the fractional order nonlinear integral equation (3). We make a variable transformation in integral equation (3): $s=\frac{t \tau}{T}, \quad \tau \in\left(t_{0} ; T\right)$. Applying the generalized Jacobi-Galerkin method to equation (28), we come to the system (30). By using the quadrature formula we obtain the necessary approximation formulas (31) and (32).

\section{References}

1 Hilfer R. Application of fractional calculus in physics / R. Hilfer. - Singapore: World Scientific Publishing Company, 2000. - $472 \mathrm{p}$.

2 Tenreiro Machado J.A. Handbook of fractional calculus with applications / J.A. Tenreiro Machado. Vols. 1-8. - Berlin, Boston: Walter de Gruyter GmbH, 2019.

3 Hilfer R. Experimental evidence for fractional time evolution in glass forming materials / R. Hilfer // Chemistry, Physics. - 2002. - 284. - № 1-2. - P. 399-408.

4 Hilfer R. On fractional relaxation / R. Hilfer // Fractals. - 2003. - 11. - Supp. 01. - Part III: Scaling. - P. 251-257.

5 Hilfer R. Operational method for the solution of fractional differential equations with generalized RiemannLiouville fractional derivatives / R. Hilfer, Y. Luchko, Z. Tomovski // Fractional Calculus and Applied Analyses. - 2009. - 12. - № 3. - P. 299-318.

6 Kim M.Ha. Operational method for solving multi-term fractional differential equations with the generalized fractional derivatives / M.Ha Kim, Ri.G. Chol, O.H. Chol // Fractional Calculus and Applied Analyses. - 2014. - 17. - № 1. - P. 79-95.

7 Samko S.G. Fractional integrals and derivatives. Theory and Applications / S.G. Samko, A.A. Kilbas, O.I. Marichev. - Gordon and Breach: Yverdon, 1993.

8 Mainardi F. Fractional calculus: some basic problems in continuum and statistical mechanics / F. Mainardi. - In: Carpinteri A. Fractals and Fractional Calculus in Continuum Mechanics / A. Carpinteri, F. Mainardi. - Wien: Springer, 1997. 
9 Area I. On a fractional order Ebola epidemic model / I. Area, H. Batarfi, J. Losada, J.J. Nieto, W. Shammakh, A. Torres // Advances in Differential Equations. - 2015. - 1. - ID 278.

10 Hussain A. Existence of solution and stability for the fractional order novel coronavirus (nCoV-2019) model / A. Hussain, D. Baleanu, M. Adeel // Advances in Differential Equations. - 2020. - ID 384.

11 Ullah S. A fractional model for the dynamics of tuberculosis infection using Caputo-Fabrizio derivative / S. Ullah, M. A. Khan, M. Farooq, Z. Hammouch, D. Baleanu // Discrete Continuous Dynamic Systems. Series S. - 2020. - 13. - № 3. - P. 975-993.

12 Kumar D. Editorial: Fractional calculus and its applications in physics / D. Kumar, D. Baleanu // Frontiers Physics. - 2019. - 7. - ID 81.

13 Sun H. A review on variable-order fractional differential equations: mathematical foundations, physical models, numerical methods and applications / H. Sun, A. Chang, Y. Zhang, W. Chen // Fractional Calculus and Applied Analyses. - 2019. - 22. - № 1. - P. 27-59.

14 Saxena R.K. Analytical solution of space-time fractional telegraph-type equations involving Hilfer and Hadamard derivatives / R.K. Saxena, R. Garra, E. Orsingher // Integral Transforms and Special Functions. - 2015. - 27. - № 1. - P. 30-42.

15 Patnaik S. Applications of variable-order fractional operators: a review / S. Patnaik, J.P. Hollkamp, F. Semperlotti // Proceedings of the Royal Society. A. - 2020. - 476. - № 2234. - 32 p.

16 Sandev T. Fractional equations and models: Theory and applications / T. Sandev, Z. Tomovski // Developments in Mathematics. - 61. - Switzerland, Springer Nature Switzerland AG, 2019. — 345 p.

17 Yuldashev T.K. Boundary value problem for weak nonlinear partial differential equations of mixed type with fractional Hilfer operator / T.K. Yuldashev, B.J. Kadirkulov // Axioms. - 2020. - 9. - № 2. ID 68. $-19 \mathrm{p}$.

18 Yuldashev T.K. Nonlocal problem for a mixed type fourth-order differential equation with Hilfer fractional operator / T.K. Yuldashev, B.J. Kadirkulov // Ural Mathematical Journal. — 2020. — 6. — № 1. - P. 153167.

19 Yuldashev T.K. Inverse problem for a mixed type integro-differential equation with fractional order Caputo operators and spectral parameters / T.K. Yuldashev, E.T. Karimov // Axioms. - 2020. - 9. - № 4. - ID 121. - 24 p.

20 Yuldashev T.K. Inverse boundary value problem for a fractional differential equations of mixed type with integral redefinition conditions /T.K. Yuldashev, B.J. Kadirkulov // Lobachevskii Journal of Mathematics. - 2021. - 42. - № 3. - P. 649-662.

21 Yuldashev T.K. On a boundary value problem for a mixed type fractional differential equations with parameters / T.K. Yuldashev, B.J. Kadirkulov // Proceedings of the Institute of Mathematics and Mechanics, National Academy of Sciences of Azerbaijan. - 2021. - 47. - № 1. P. 112-123.

22 Yuldashev T.K. On boundary value problems for a mixed type fractional differential equation with Caputo operator / T.K. Yuldashev, B.I. Islomov, U.Sh. Ubaydullaev // Bulletin of the Karaganda University. Mathematics serie. 2021. - 101. - № 1. - P. 127-137.

23 Marakhimov A.R. Approach to the synthesis of neural network structure during classification / A.R. Marakhimov, K.K. Khudaybergenov // International Journal of Computing. 2020. - 19. — № 1. — P. 20-26.

24 Marakhimov A.R. A structural synthesis of information computer networks of automated control systems based on genetic algorithms / Marakhimov A.R., Siddikov I.H., Nasridinov A., Byun J.-Y. // Lecture Notes in Electrical Engineering. - 2015. - 330. - P. 1055-1063.

25 Assanova A.T. Numerical implementation of solving a boundary value problem for a system of loaded differential equations with parameter / A.T. Assanova, E.A. Bakirova, Zh.M. Kadirbayeva // News of the NAS Republic of Kazakhstan. Series Physics-Mathematics. — 2019. — 3. — № 325. - P. 77-84.

26 Bakirova E.A. On one algorithm for finding a solution to a two-point boundary value problem for loaded differential equations with impulse effect / E.A. Bakirova, A.B. Tleulesova, Zh.M. Kadirbayeva // Bulletin of the Karaganda University. Mathematics. - 2017. - 87. — № 3. - P. 43-50.

27 Асанова А.Т. Численное решение задачи управления для интегро-дифференциальных уравнений / А.Т. Асанова, Е.А. Бакирова, Ж.М. Кадирбаева // Журн. вычисл. мат. и мат. физ. - 2020. - 60. - № 2. - C. 197-215.

28 Boyd J.P. Chebyshev and Fourier spectral methods / J.P. Boyd. - Springer, Verlag, Berlin, 1989. 
29 Brunner H. Collocation methods for Volterra integral and related functional differential equations H. Brunner. - Cambridge University Press, Cambridge, 2004.

30 Funaro D. Polynomial approximations of differential equations / D. Funaro. - Springer, Verlag, 1992.

31 Guo B. Spectral methods and their applications / B. Guo. - World Scientific, Singapore, 1998.

32 Kadirbayeva Zh.M. On the method for solving linear boundary-value problem for the system of loaded differential equations with multipoint integral condition / Zh.M. Kadirbayeva // Mathematical Journal. - 201. - 17. - № 4. - P. 50-61.

33 Pimenov V.G. Fractional analog of crank-nicholson method for the two sided space fractional partial equation with functional delay / V.G. Pimenov, A.S. Hendy // Ural Mathematical Journal. - 2016. - 2. - № 1. - P. 48-57.

34 Пименов В.Г. Численный метод для дробных уравнений адвекции-диффузии с наследственностью / В.Г. Пименов // Итоги науки и техн. Сер. Современная математика и ее приложения. Тематические обзоры. - 132. - М.: ВИНИТИ РАН, 2017. - С. 86-90.

35 Shen J. Generalized Jacobi Spectral-Galerkin method for nonlinear Volterra integral equations with weakly singular kernels / J. Shen, Ch. Sheng, Zh. Wang // Journal of Mathematical Study. - 2015. - 48. - № 4. - P. 315-329.

36 Юлдашев Т.К. Приближенное решение системы нелинейных интегральных уравнений с запаздывающим аргументом и приближенное вычисление функционала качества / Т.К. Юлдашев, С.М. Овсянников // Журн. Средневолж. мат. общ-ва. - 2015. - Т. 17. - № 2. - С. 85-95.

37 Юлдашев Т.К. Предельная задача для системы интегро-дифференциальных уравнений с двухточечными смешанными максимумами / T.К. Юлдашев // Вестн. Самар. гос. техн. ун-та. Сер. Физ.-мат. науки. - 2008. - Т. 1. - № 16. - С. 15-22.

38 Berdyshev A.S. On a nonlocal problem for a fourth-order parabolic equation with the fractional Dzhrbashyan-Nersesyan operator / A.S. Berdyshev, J.B. Kadirkulov // Differential Equations. - 2016. - 52. - № 1. - P. 122-127.

39 Malik S.A. An inverse source problem for a two parameter anomalous diffusion equation with nonlocal boundary conditions / S.A. Malik, S. Aziz // Computers and Mathematics with Applications. - 2017. 73. - № 12 . - P. 2548-2560.

40 Erdelyi A. Higher transcendental functions (Bateman Manuscript Project) / A. Erdelyi - 1. - McGrawHill New York, California Institute of Technology, 1953.

41 Chen S. Generalized Jacobi functions and their applications to fractional differential equations / S. Chen, J. Shen, L. Wang // Mathematics, Computer Sciences. - 2016. - 85. - P. 1603-1638.

\author{
Т.К. Юлдашев ${ }^{1}$, Б.Ж. Кадиркулов ${ }^{2}$, А.Р. Марахимов ${ }^{3}$ \\ ${ }^{1}$ Өзбекстан ұлттық, университеті, Ташкент, Өзбекстан; \\ ${ }^{2}$ Ташкент мемлекеттік Шызыстану Университеті, Ташкент, Өзбекстан; \\ ${ }^{3}$ Термез мемлекеттік университеті, Термез, Өзбекстан
}

\title{
Сызықтық емес оң жағы бар Хильфер типтес бөлшек дифференциалдық теңдеу туралы
}

\begin{abstract}
Мақалада максималды сызықтық емес бөлшек дифференциалдық теңдеу үшін бастапқы есепті біркелкі шешу және сандық іске асыру мәселелері қарастырылды. Дирихле формуласына негізделген қарапайым интегралдық түрлендіруді қолдана отырып, қарастырылып отырған бастапқы міндет Вольтерр типіндегі сызықты емес бөлшек интегралдық теңдеуге дейін азаяды. Қарастырылған сегментте берілген бастапқы есепті шешудің бар болуы мен бірегейлігі теоремасы дәлелденді. Шешімді сандық түрде жүзеге асыру үшін Галеркин Якобидің жалпыланған спектрлік әдісі қолданылған. Көрнекі мысалдар келтірілген.
\end{abstract}

Kiлm сөздер: қарапайым дифференциалдық теңдеу, максимумдармен теңдеу, Хильфер операторы, бір мәнді шешімділік, Галеркин Якобидің жалпыланған спектрлік әдісі. 


\author{
Т.К. Юлдашев ${ }^{1}$, Б.Ж. Кадиркулов ${ }^{2}$, А.Р. Марахимов ${ }^{3}$ \\ ${ }^{1}$ Национальный университет Узбекистана, Ташкент, Узбекистан; \\ ${ }^{2}$ Ташкентский государственный университет востоковедения, Ташкент, Узбекистан; \\ ${ }^{3}$ Термезский государственный университет, Термез, Узбекистан
}

\title{
Об одном дробном дифференциальном уравнении типа Хильфера с нелинейной правой частью
}

\begin{abstract}
В статье рассмотрены вопросы однозначной разрешимости и численной реализации начальной задачи для нелинейного дробного дифференциального уравнения типа Хильфера с максимумами. С помощью несложного интегрального преобразования, основанного на формуле Дирихле, рассматриваемая начальная задача сведена к нелинейному дробно-интегральному уравнению типа Вольтерра. Доказана теорема существования и единственности решения заданной начальной задачи на рассматриваемом отрезке. Для численной реализации решения применен обобщенный спектральный метод ГалеркинаЯкоби. Приведены наглядные примеры.
\end{abstract}

Ключевые слова: обыкновенное дифференциальное уравнение, уравнение с максимумами, оператор Хильфера, однозначная разрешимость, обобщенный спектральный метод Галеркина-Якоби.

References

1 Hilfer, R. (2000). Application of Fractional Calculus in Physics. World Scientific Publishing Company, Singapore.

2 Tenreiro Machado, J.A. (2019). Handbook of Fractional Calculus with Applications. Vols. 1-8. Berlin, Boston: Walter de Gruyter GmbH.

3 Hilfer, R. (2002). Experimental evidence for fractional time evolution in glass forming materials. Chemistry, Physics, 284, 1-2, 399-408.

4 Hilfer, R. (2003). On fractional relaxation. Fractals, Vol. 11, Supp. 01 (Part III: Scaling), 251-257. DOI: $10.1142 / \mathrm{S} 0218348 \mathrm{X} 03001914$

5 Hilfer, R., Luchko, Y., \& Tomovski Z. (2009). Operational method for the solution of fractional differential equations with generalized Riemann-Liouville fractional derivatives. Fractional Calculus and Applied Analyses, 12, 3, 299-318.

6 Kim, M.Ha, Chol, Ri.G., \& Chol O.H. (2014). Operational method for solving multi-term fractional differential equations with the generalized fractional derivatives. Fractional Calculus and Applied Analyses, 17, 1, 79-95.

7 Samko, S.G., Kilbas, A.A., \& Marichev, O.I. (1993). Fractional Integrals and Derivatives. Theory and Applications. Gordon and Breach, Yverdon.

8 Mainardi, F. (1997). Fractional calculus: some basic problems in continuum and statistical mechanics. In: Carpinteri, A., Mainardi, F. Fractals and Fractional Calculus in Continuum Mechanics. Springer, Wien.

9 Area, I., Batarfi, H., Losada, J., Nieto, J. J., Shammakh, W., \& Torres, A. (2015). On a fractional order Ebola epidemic model. Advances in Differential Equations, 1, ID 278.

10 Hussain, A., Baleanu, D., \& Adeel, M. (2020). Existence of solution and stability for the fractional order novel coronavirus (nCoV-2019) model. Advances in Differential Equations, ID 384.

11 Ullah, S., Khan, M.A., Farooq, M., Hammouch, Z., \& Baleanu, D. (2020). A fractional model for the dynamics of tuberculosis infection using Caputo-Fabrizio derivative. Discrete Continuous Dynamic Systems. Series S., 13, 3, 975-993.

12 Kumar, D., \& Baleanu, D. (2019). Editorial: fractional calculus and its applications in physics. Frontiers Physics, 7, 6, ID 81.

13 Sun, H., Chang, A., Zhang, Y., \& Chen, W. (2019). A review on variable-order fractional differential equations: mathematical foundations, physical models, numerical methods and applications. Fractional Calculus and Applied Analyses, 22, 1, 27-59. 
14 Saxena, R.K., Garra, R., \& Orsingher, E. (2015). Analytical solution of space-time fractional telegraphtype equations involving Hilfer and Hadamard derivatives. Integral Transforms and Special Functions, 27, 1, 30-42.

15 Patnaik, S., Hollkamp, J.P., \& Semperlotti, F. (2020). Applications of variable-order fractional operators: a review. Proceedings of Royal Society. Series A. Vol. 476, 2234, 1-32.

16 Sandev, T., \& Tomovski, Z. (2019). Fractional Equations and Models: Theory and Applications. Development in Mathematics, 61. Springer Nature Switzerland AG.

17 Yuldashev, T.K., \& Kadirkulov, B.J. (2020). Boundary value problem for weak nonlinear partial differential equations of mixed type with fractional Hilfer operator. Axioms, 9, 2(68), 1-19.

18 Yuldashev, T.K., \& Kadirkulov, B.J. (2020). Nonlocal problem for a mixed type fourth-order differential equation with Hilfer fractional operator. Ural Mathematics Journal, 6, 1, 153-167.

19 Yuldashev, T.K., \& Karimov, E.T. (2020). Inverse problem for a mixed type integro-differential equation with fractional order Caputo operators and spectral parameters. Axioms, 9, 4(121), 1-19.

20 Yuldashev, T.K., \& Kadirkulov, B.J. (2021). Inverse boundary value problem for a fractional differential equations of mixed type with integral redefinition conditions. Lobachevskii Journal of Mathematics, 42, 3, 649-662.

21 Yuldashev, T.K., \& Kadirkulov, B.J. (2021). On a boundary value problem for a mixed type fractional differential equations with parameters. Proceedings of the Institute of Mathematics and Mechanics, National Academy of Sciences of Azerbaijan, 47, 1, 112-123.

22 Yuldashev, T.K., Islomov, B.I., \& Ubaydullaev, U.Sh. (2021). On boundary value problems for a mixed type fractional differential equation with Caputo operator. Bulletin of the Karaganda University. Mathematics series, 101, 1, 127-137.

23 Marakhimov, A.R., \& Khudaybergenov, K.K. (2020). Approach to the synthesis of neural network structure during classification. International Journal of Computing, 19, 1, 20-26.

24 Marakhimov, A.R., Siddikov, I.H., Nasridinov A., \& Byun, J.Y. (2015). A structural synthesis of information computer networks of automated control systems based on genetic algorithms. Lecture Notes in Electrical Engineering, 330, 1055-1063.

25 Assanova, A.T., Bakirova, E.A., \& Kadirbayeva, Zh.M. (2019). Numerical implementation of solving a boundary value problem for a system of loaded differential equations with parameter. News of the NAS Republic of Kazakhstan. Series Phyics-Mathematics, 3, 325, 77-84.

26 Bakirova, E.A., Tleulesova, A.B., \& Kadirbayeva, Zh.M. (2017). On one algorithm for finding a solution to a two-point boundary value problem for loaded differential equations with impulse effect. Bulletin of the Karaganda University- Mathematics, 87, 3, 43-50.

27 Assanova, A.T., Bakirova, E.A., \& Kadirbayeva, Zh.M. (2020). Chislennoe reshenie zadachi upravleniia dlia integro-differentsialnykh uravnenii [Numerical solution to a control problem for integro-differential equations]. Zhurnal vychislennoi matematiki i matematicheskoi fiziki - Computational Mathematics and Mathematical Physics, 60, 2, 203-221 [in Russian].

28 Boyd, J.P. (1989). Chebyshev and Fourier Spectral Methods. Springer, Verlag, Berlin.

29 Brunner, H. (2004) Collocation methods for Volterra Integral and Related Functional Differential Equations. Cambridge University Press, Cambridge.

30 Funaro, D. (1992). Polynomial Approximations of Differential Equations. Springer, Verlag.

31 Guo, B. (1998). Spectral Methods and Their Applications. World Scientific, Singapore.

32 Kadirbayeva, Zh.M. (2017). On the method for solving linear boundary-value problem for the system of loaded differential equations with multipoint integral condition. Mathematical Journal, 17, 4, 50-61.

33 Pimenov, V.G., \& Hendy, A.S. (2016) Fractional analog of Crank-Nicholson method for the two sided space fractional partial equation with functional delay. Ural Mathematical Journal, 2, 1, 48-57.

34 Pimenov, V.G. (2018). Chislennyi metod dlia drobnykh uravnenii advektsii-diffuzii s nasledstvennostiu Itogi nauki i tekhniki [Numerical methods for fractional advection-diffusion equation with heredity]. Seriis Sovremennaia matematika $i$ ee prilozheniia. Tematicheskie obzory - Journal of Mathematical Sciences (New York), 230, 5, 737-741 [in Russian].

35 Shen, J., Sheng, Ch., \& Wang, Zh. (2015). Generalized Jacobi Spectral-Galerkin method for nonlinear Volterra integral equations with weakly singular kernels. Journal of Mathematical Study, 48, 4, 315-329. 
36 Yuldashev, T.K., \& Ovsyannikov, S.M. (2015). Priblizhennoe reshenie sistemy nelineinykh integralnykh uravnenii s zapazdyvaiushchim argumentom i priblizhennoe vychislenie kachestva funktsionala [An approximate solution of a system of nonlinear integral equations with a delay argument and an approximate calculation of the quality functional]. Zhurnal Srednevolzhskogo matematicheskogo obshchestva - Journal of Middle Volga Mathematical Society, 17, 2, 85-95 [in Russian].

37 Yuldashev, T.K. (2008). Predelnaia zadacha dlia sistemy integro-differentsialnykh uravnenii s dvumia smeshannymi maksimumami [Limit value problem for a system of integro-differential equations with two mixed maxima]. Vestnik Samarskogo gosudarstvennogo tekhnicheskogo universiteta. Seriia Fizikomatematicheskie nauki - Buletin of Samara State Technical University. Physics and Mathematics, 1, 16, 15-22 [in Russian].

38 Berdyshev, A.S., \& Kadirkulov, J.B. (2016). On a nonlocal problem for a fourth-order parabolic equation with the fractional Dzhrbashyan-Nersesyan operator. Differential Equations, 52, 1, 122-127.

39 Malik, S.A., \& Aziz, S. (2017). An inverse source problem for a two parameter anomalous diffusion equation with nonlocal boundary conditions. Computers and Mathematics with Applications, 73, 12, $2548-2560$.

40 Erdelyi, A. (1953). Higher Transcendental Functions (Bateman Manuscript Project). 1. California Institute of Technology, McGraw-Hill New York.

41 Chen, S., Shen, J., \& Wang, L. (2016). Generalized Jacobi Functions and Their Applications to Fractional Differential Equations. Mathematics, Computer Sciences, 85, 1603-1638. 


\section{АВТОРЛАР ТУРАЛЫ МӘЛІМЕТТЕР СВЕДЕНИЯ ОБ АВТОРАХ INFORMATION ABOUT AUTHORS}

Abdul Rahman, N.A. - Doctor of Mathematical Sciences, Professor, School of Mathematical Sciences, Universiti Sains Malaysia (USM), Penang, Malaysia.

Ahmed, D.F. - PhD, Lecturer, University of Sulaimani, College of Education, Department of Mathematics, Sulaimani, Iraq.

Alibieva, D.T. - Doctoral student of the Department of Mathematical Analysis and Differential Equations, Karagandy university of the name of academician E.A. Buketov, Kazakhstan.

Bhat, A.H. - Master of philosophy (Mathematics), Research Scholar of the Department of Applied Sciences and Humanities, Faculty of Engineering and Technology, Jamia Millia Islamia (A Central University), New Delhi, India.

Bitimkhan, S. - Candidate of physical and mathematical sciences, Docent of the Department of Mathematical Analysis and Differential Equations, Karagandy university of the name of academician E.A. Buketov, Kazakhstan.

Davoodi, S.M. - PhD, Candidate of Mathematical Sciences, School of Mathematical Sciences, Universiti Sains Malaysia (USM), Penang, Malaysia.

Hama, M.F. - PhD, Assistant Professor, University of Sulaimani, College of Science, Department of Mathematics, Sulaimani, Iraq.

Hasan, H.M. - Master, Assistant Lecturer, University of Sulaimani, College of Basic Education, Department of Mathematical Sciences, Sulaimani, Iraq.

Ibraev, Sh.Sh. - Candidate of physical and mathematical sciences, Associate professor of the Department of Physics and Mathematics, Korkyt Ata Kyzylorda University, Kyzylorda, Kazakstan.

Ibrayeva, A.A. - Master of pedagogical sciences, Senior lecturer of the Department Physics and Mathematics, Korkyt Ata Kyzylorda University, Kyzylorda, Kazakhstan.

Imanbaev, N.S. - Candidate of physical and mathematical sciences, Professor, Department of Mathematics, South Kazakhstan State Pedagogical University, Shymkent, Kazakhstan; Chief Researcher, Institute of Mathematics and Mathematical Modeling, Almaty, Kazakhstan.

Issayeva, A.K. - PhD student, Karagandy university of the name of academician E.A. Buketov, Kazakhstan.

Javidi, M. - PhD, Professor assistance, Faculty of Mathematical Sciences, University of Tabriz, Iran.

Jetpisbayeva, A.E. - PhD student, L.N. Gumilyov Eurasian National University, Nur-Sultan, Kazakhstan.

Jumabayeva, A.A. - PhD, Acting Associate Professor, L.N. Gumilyov Eurasian National University, NurSultan, Kazakhstan.

Jwamer, K.H.F. - PhD, Professor, University of Sulaimani, College of Science, Department of Mathematics, Iraq.

Kadirkulov, B.J. - Doctor of Physical and Mathematical Sciences, Professor, Chief of the Department of Mathematics and Informatics, Tashkent State University of Oriental Studies, Uzbekistan. 
Kasimov, A.T. - Candidate of technical sciences, Docent, Docent of the Department of Building Materials and Technologies, Karaganda Technical University, Kazakhstan.

Kurmysh, Ye. - Candidate of physical and mathematical sciences, Docent, Department of Mathematics, South Kazakhstan State Pedagogical University, Shymkent, Kazakhstan.

Majid, J. - Master of philosophy (Mathematics), Research Scholar of the Department of Applied Sciences and Humanities, Faculty of Engineering and Technology, Jamia Millia Islamia (A Central University), New Delhi, India.

Marakhimov, A.R. - Doctor of Technical Sciences, Professor, Rector of Termez State University, Uzbekistan.

Nazarova, K.Zh. - PhD (Physics and Mathematics), Associate Professor of Mathematics, Department of Mathematics, Khoja Akhmet Yassawi International Kazakh-Turkish University, Turkistan, Kazakhstan.

Noiri, T. - PhD, Professor, Yatsuhiro, Japan.

Parasidis, I.N. - PhD, Professor, University of Thessaly, Larissa, Greece.

Providas, E. - PhD, Associate Professor, Head of the Department of Environmental Sciences, University of Thessaly, Larissa, Greece.

Qureshi, M.I. - Doctor of philosophy (Mathematics), Professor of the Department of Applied Sciences and Humanities, Faculty of Engineering and Technology, Jamia Millia Islamia (A Central University), New Delhi, India.

Rad, M.J. - PhD, Professor assistance, Department of Mathematics, Islamic Azad University Tabriz Branch, Iran.

Roy, B. - PhD, Associate Professor, Women's Christian College, Kolkata, India.

Saei, F.D. - PhD, Professor assistance, Department of Mathematics, Islamic Azad University Tabriz Branch, Iran.

Saghali, S. - PhD student, Department of Mathematics, Islamic Azad University Tabriz Branch, Iran.

Shamatayeva, N.K. - PhD, Docent of the Department of Methods of Teaching Mathematics and Informatics, Karagandy university of the name of academician E.A. Buketov, Kazakhstan.

Syzdykova, N.K. - Candidate of physical and mathematical sciences, Head of the Department of Methods of Teaching Mathematics and Computer Science, Karagandy university of the name of academician E.A. Buketov, Kazakhstan.

Tarasova, O.A. - Senior Lecturer, Belgorod State National Research University, Russia.

Usmanov, K.I. - PhD (Physics and Mathematics), Associate Professor of Mathematics, Department of Mathematics, Khoja Akhmet Yassawi International Kazakh-Turkish University, Turkistan, Kazakhstan.

Vasilyev, A.V. - Senior Developer, OOO Severgrup TT, Moscow, Russia.

Vasilyev, V.B. - Doctor of Physical and Mathematical Sciences, Professor, Belgorod State National Research University, Russia.

Yeshkeyev, A.R. - Doctor of Physical and Mathematical Sciences, Professor of the Department of Algebra, Mathematical Logic and Geometry named after Professor T.G. Mustafin, Karagandy university of the name of academician E.A. Buketov Kazakhstan.

Yeshmurat, G.K. - Master of pedagogical sciences, Senior lecturer of the Department of Physics and Mathematics, Korkyt Ata Kyzylorda University, Kazakhstan.

Yessenbayeva, Gulmira A. - Doctor of Pedagogical Sciences, Candidate of technical sciences, Docent, Corresponding Member of the Russian Academy of Natural Sciences, Head of the Department of Commodity Science and Certification, Karaganda University of Kazpotrebsoyuz, Kazakhstan.

Yessenbayeva, Gulsim A. - Candidate of physical and mathematical sciences, Docent of the Prof. T.G. Mustafin Algebra, Mathematical Logic and Geometry Department, Karagandy university of the name of academician E.A. Buketov Kazakhstan. 
Yuldashev, T.K. - Candidate of Physical and Mathematical Sciences, Docent, Associate Professor, UzbekIsrael Joint Faculty of High Technolofy and Engineering Mathematics, National University of Uzbekistan, Tashkent, Uzbekistan. 